Felipe II pasó mucho tiempo de viaje en 1585. Primero fue hasta Zaragoza, donde el día 14 de abril casaba a su hija, la infanta Catalina Micaela, con el Duque de Saboya. Después celebrará cortes en Monzón y, por último, irá a Valencia con el mismo propósito, donde todavía está a comienzos de 1586. El rastro que deja el epistolario de Liaño sigue de cerca estos traslados de la corte después de llegar desde Italia en enero, llevando regalos y para acompañar al Duque de Saboya desde Barcelona a Zaragoza. En febrero, mientras está en Vilafranca del Penedès, le ocurre una de esas desgracias propias de su condición de agente: el pardo o tigre que traía a España por encargo del Gran Duque, se muere. Las explicaciones que da por carta procuran exonerar al cuidador del animal:

no se á podido haçer más, de lo que yo doy mi palabra a V. A. serenísima, de que el pardero es tan hombre de vien y tan afiçionado al serviçio de $\mathrm{V}$. alteza que no puede ser más. Y ansí le aconsejé que, pues el pardo hera muerto, sería mejor volver a Florençia; ansí lo a hecho. Áme pessado tanto a mí como si se me ubiera muerto un hermano mío ${ }^{44}$

No fueron buenos tiempos para el pobre Gonzalo, que tiene que sufrir maltrato para diversión del Duque de Saboya, según relata Arandilla o Arandica, otro agente, bufón y amigo ${ }^{45}$, que fue parte doliente de la misma burla cortesana, en la que destaca los arrestos de Gonzalo atacando:

En lo que toca a Gonzalillo y a mí, abías de saber que [el Duque] trae un loco o por mejor dezir un boracho [sic] que á enbestido con Gonzalillo un día delante el duque. Y aque

${ }^{44}$ ASF, MP, 771, ff. 439 r., carta al Gran Duque desde Villafranca, 7 de febrero 1585.

${ }^{45}$ Según S. Salort y S. Kubersky-Piredda, art. cit., 2006, p 660, n. 5, Arandilla era también un enano agente entre Austria y Toscana, cuyo nombre auténtico era Nicolás Castellanos. Efectivamente las numerosas cartas que se conservan de Arandilla al Gran Duque mencionan sus estancias en la corte del emperador, en Saboya, en Florencia y también en España; en ellas se refiere a Gonzalo con admiración y encarecimiento en bastantes ocasiones. Entre ambos hombres debía existir una relación fraterna, porque en carta de 3 de febrero de 1586 (ASF, MP, 5938, f. 629-630) Gonzalo dice a la Gran fraterna, porque en carta de 3 de febrero de 1586 (ASF, MP, 5938 , f. 629-630) Gonzalo dice a la Gran lumbre y está muy cuerdo y no juega, y muy agradesçido del bien que V.A. le ha hecho; y agora está de manera que me puede a mí favoresçer". Ese era el cargo que ocupaba anteriormente el propio Gonzalo, a juzgar por la carta del embajador de Saboya en Madrid al Duque su patrón en 1583 para presentarle: "Callaré que es despavilador del rey y su mucha privança por dezir en dos palabras a Vuestra Alteza, que es la crónica de toda la corte", apud S. Salort y S. Kubersky-Piredda, art. cit., 2006, p 660, n. 1. En carta de 4 de julio de 1583 le dice al Gran Duque: "dixéronmi que my responderiano quando yo me partiesse para V. A., al qual tiempo yría allá como medio embaxador" (ASF, MP, 762, ff. 210-211); y en la de agosto de 1587 le explica a la Gran Duquesa, con cierto tono jocoso, que va como embajador y cuáles han de ser los recibimientos.

\section{LECTURA Y SIGNO}

\author{
REVISTA DE LITERATURA
}


Y no sé si yo estoy enamorado de vos, y esto es para entre mí y vos, y no lo digáys al Gran Duque porque no me pida celos, porque si como o çeno, que es quando mi coraçón está contento, entonces me acuerdo de mi buena Gran Duquesa y no tengo otro desseo sino bolverme a estar con vos. Y no podrá ser menos, porque teniendos vos el alma, el cuerpo ¿cómo podrá estar sin el alma? Y verdaderamente en este particular os podría dezir muchas cosas, porque vos lo merecéys y hartas veces me acuerdo, que quando estava yo afligido y desconsolado, érades vos mi consoladora. Anoche cené con la señora Clelia y estuvimos muy alegres, porque tuve el humor y tomé un laúd, y dixe tantos disparates que la señora Clelia se caýa de la silla riendo. Y también merendé en casa de la señora Costanza y estuvimos muy alegres, y vino el cardenal Sforza, que en viéndome comer, le dio apetito. Y está tan flaco que os espantaréys, que si no tubiese sperança de su mocedad, yo entiendo que tarde convalescería. Yo vi la processión el día del Corpu Christi, que fue cosa de ver, y estuve a la puerta con el cardenal que le cabe governar la processión con otros dos obispos, y hizo muy bien su officio. Y nunca me quité de su lado, porque no me diessen alguna bastonada tudesca estos de la guarda y el seño Jacomo Bonconpagno me dio la mano drecha por ser hombre que lo merecía. El domingo soy combidado con Tuya con su amorosa en una viña, Sangaleto haze la costa. La embaxadora y el embaxador me hazen muchos regalos, aunque el coraçón del embaxador no es muy cattólico, porque alguna vez [roto ¿me?] quiere dar xaque de peón y yo le respondo con el cavallo sobre [roto ia-?] quel amigo que está en Nápoles. El Gran Duque lo entenderá muy [roto ¿bi-?] en.

Yo voy entendiendo en procurar de despachar y hazer lo que vos [roto ¿me?] mandáys, yo me remito al Cardenal, que él dirá quando andare [roto ¿allá?]. Asta aora no he podido alcançar dineros, no hazen sino combidarme a comer y banquetearme, que es lo que yo no he menester, y danme con la señoría ilustrísima tantas que soy hombre que la vendería por qualquier dinero que me diessen. Y es tanto lo que podéys en esta corte y vuestro valor y fama que buela acá. Los españoles que no traen otro en la boca sino alabanças vuestras y en las occasiones que me hallo me da Dios tanta gracia en esto que sé muy bien dezir mi razón en cosas que tocan a vuestro servicio, de muchas mercedes que hazéys a vuestro amigo Goncalico. Quiero que hagáys esta, que scribáys a Jacomo Boncompagno y al cardenal de Este en recomendación mía, porque tengo tantas memorias de señoras de la corte que me cansan y soy tan amigo de hazer lo que se me encarga que no querría por ninguna vía faltar. Y porque soy cierto que no me havéys de desamparar, sino siempre favorecer a Dios. Gran Duquesa y Gran Duque y plegue a Dio que presto me vea con vosotros, que no desseo otra cosa sino daros contento y gusto, $y$ procurad de conservar a Gonçalico en vuestra buena gracia. De Roma y de junio e primero de 1584.43

Vuestro verdadero amigo que tanto os dessea servir 
muriera y aun cagado en las calças. Esotro día fue el sábado, entró el cardenal a mediodía y yo me quedé atrás, y la amiga de Tuya salió en un coche a una porta a recivirle, y hiziéronse tantas caricias y se besaron y lloraron de contento, y vinieron a Roma y entrambos a dos se fueron a una stufa ${ }^{39}$

Esto es las nuevas que hay, aunque en casa de Jacobo Boncompagno estava un bandido que Jacomo lo havía asegurado, mas su Santidad lo ha mandado prender y sacarlo de su casa. Yo tengo desseo de acabar mis negocios y después negociar lo que $\mathrm{V}$. alteza me havéys encomendado, que yo tengo más desseo de andar allá, porque aquí me muero de calor. Ni he començado a visitar a nadie, porque no era venido mi baúl, de mañana començaré y porque tengo el humor. Nuestro Señor os guarde a vos y al Gran Duque como vuestro verdadero amigo Gonçalo, que tanto os ama, dessea. De Roma y de mayo a 15 de 1584

Vuestro verdadero amigo para lo que me mandareys,

\section{Gonçalo de Liaño ${ }^{4}$}

La vida en Roma, tal como la cuenta Liaño, parece ofrecer constantes diversiones, a las que no hace remilgos, según le relata a la Gran Duquesa con el fin de divertirla. Los halagos sobre la fama que tiene, la que él le proporciona y su enamoramiento, expresado en conceptos neplatónicos propios de la poesía culta, desembocan en una petición de recomendaciones para Giacomo Boncompagno, hijo del papa Gregorio XIII"1, y para el Cardenal d'Este, es decir, Luigi d'Este ${ }^{42}$, sin explicarle realmente para qué las necesita, puesto que la mención de las cartas de las damas le da una excusa de apariencia galante, pero muy poco verosímil. Gonzalo recurre casi siempre a estas cartas de presentación para asegurarse una buen recibimiento, además le ofrecen una forma de enaltecer su prestigio por medio del elogio ajeno y dan garantía a sus palabras, todo ello para asegurarse el buen éxito de sus gestiones.

\section{Serenísima Gran Duquesa y especial y verdadera amiga:}

Para mí es tanto el contento quando veo carta vuestra que me [roto ¿vuelvo?] más loco de lo que estoy, de contento de ver que estoy tan en vuestra buena gracia y del Gran Duque.

39 Stufa: Entonces en Roma se conocían con el nombre de stufe los baños públicos.

${ }^{40}$ ASF, MP, 5936, ff. 544 r.-v.

${ }^{1}$ Giacomo Boncompagni (1548- 1612), duque de Sora y marqués de Vignola, desempeñó numerosos cargos militares y administrativos en el Vaticano

2 Luigi Cardinal d'Este (1538-1586) era uno de los cardenales más poderosos del Colegio y mantenía una excelente relación con Francia, país del que fue nombrado Cardenal Protector.

\section{LECTURA Y SIGNO}

\author{
REVISTA DE LITERATURA
}

Vol. 4, 2009
UNVERSIDAD DELEÓN

Área de publicaciones

2009 
Florencia no era el único destino de Gonzalo en Italia. En los viajes de ida y vuelta o por encargos particulares, debía pasar por otras ciudades. Después de haber estado un tiempo en Florencia, debe ir a Roma, donde la vida no era menos animada o quizá lo fuera incluso más. En Roma Gonzalo describe su relación con un círculo de españoles e italianos, posiblemente formado por gente de placer como él y cortesanas, con el que entretiene sus ocios. El contenido de la siguiente carta está destinado sobre todo a divertir a la Gran Duquesa con las anécdotas de su viaje de Florencia a Roma.

\section{Sereníssima señora,}

Carta de Gonçalico scrita en Roma

La hora que os scrivo esta carta, acabo de jugar con Sangaleto y Tuya, que es aquel bufón que vino con el cardenal de Medicis, y me han ganado a la primera ${ }^{35}$ entre los dos ocho scudos, en la huerta de la Trinidad, que si no fuera porque son amigos de bandidos, creo que me diera de moxicones con ellos. La primera jornada que hizimos quando salimos de Florencia allegué muy cansado, y dormimos en una casería de un hospital de Sena y nos dieron muy bien de cenar y muy buenos vinos, aquel prete que es mayordomo del Gran Duque. Y yo no pude comer de puro cansado, y las nalgas estavan tan sacudidas del cavallo, porque se me cansó un cavallo y me hizo andar dos millas a pie hasta llegar a la posta. En fin del buen cardenal de Medicis me remedió con una mula regalada, que si no fuera por él, yo fuera muerto, y dormí aquella noche con espuelas y hize cuerpo de guardia. Todo lo que me sucedio fue aquel día.

Otro día tuve buena cama, aunque llegué muerto y el viernes passamos por el lago de Bolsena, que el cardenal me dixo que fuesse con él en una barca. Yo y Sangallo veníamos en una carroça, que como portones ${ }^{36}$ y covardes no quisimos yr con él, y después no quesiéramos que el cardenal se huviera embarcado, que como vimos el lago tan alterado el Sangaleto hizo tantas lamentaciones y llamando a Dios y a la Madona de Lorito ${ }^{37}$, que yo y él lloramos. Y en fin se apeó del coche y mandó la marcha a dos postillones ${ }^{38}$ para que bolviessen atrás y le traxessen la nueva, pero al fin el Cardenal se rio y no dio a entender lo que havía padescido, antes mostró el rostro muy alegre. Aunque me dixo un cavallero romano: "Gonçalo, si tu vinieras con nosotros, yo te aseguro que te murieras de temor". Y digo que él tiene grandíssima razón, porque como soy tan gallina, yo me

Depósito legal: LE-371-2006

Maquetación: $\mathrm{M}^{\mathrm{a}}$ Luisa Nistal Valbuena

Impresión: Universidad de León. Servicio de reprografía.

Queda prohibida cualquier forma de reproducción y transformación de esta obra sin la autorización de los titulares de la propiedad intelectual, lo que puede ser constitutivo de delito (art. 270 y ss. del Código Penal)

35 Primera: juego de cartas, que describe el Diccionario de autoridades.

36 Portones: no existe ninguna acepción del término en castellano o de un posible italiano que tenga valor adjetivo. Me sugiere con buen tino Elena di Pinto que sea una deformación de poltrone, 'gandul holgazán', con la metátesis $l / r$ característica del Lacio.

Lorito, la Virgen de Loreto, una de las advocaciones italianas más famosa

38 Postillón: mozo que va a caballo delante de los que corren la posta para guiarlos y enseñarles el camino (Autoridades). 
Cuando ya está próxima la partida, el tono de las cartas se vuelve más urgente, subrayando la necesidad de verla, la añoranza de Florencia, los aspectos que la hacen superior a Madrid y dando pinceladas sobre su vida privada a través de la mención de su esposa, con la que se ha casado ese verano. La marquesa del Valle, doña Magdalena de Guzmán, es uno de los personajes de la corte con quien más relación parece tener Liaño, la visita en todas sus estancias en Madrid y la menciona con frecuencia elogiosamente en sus cartas con los grandes duques ${ }^{31}$

\section{Sereníssima Gran Duquesa mi señora:}

Gonzalico, vuestro amado, estando ${ }^{32}$ el contendo que recibió con vuestra carta que no lo sabrá decir ni encarezer en ésta, que yo os prometo que cada ora se me haze un año asta veros, que no hai cosa que más desee. Y no me detengo por otra cosa, si no es por esperar pasaje de galeras, porque bos y el gran duque me teneis enechizado, que aunque esto casado, dejo mi muger en un monesterio por hiros a ber. Y por estar yo más seguro de los peligros desta corte y más teniendo la mujer hermosa, y ansí se á de mirar mucho por la honrra, aunque ella tiene mucha, que si no fuera ansí, no me juntara con ella. Yo me quisiera allar allá en esta primabera más que no a la merced que su merced me a echo, para gozar de los melones y otros frutos tan regalados como haí se allan y ver desos contadinos $^{33}$ con tan lindas frutas como llevan a esa plaza, con todo lo demás que es muy bueno y mejor que lo de acá, y confiado que me beré presto allá, donde me pienso de vengar. No diremos que la marquesa del Valle es tan principal y cumplida en cosas sus cosas que os quería enbiar un presente con este hordinario y como por la posta no se puede enbiar mucho, pero y ansí se abrá de quedar asta que yo baya, que será presto placiendo a Dios; el qual hos me guarde mill años. A las princesas y a la señora Peleghrina mi besa las manos; y al marquesico, y al señor Pandolfo, y Zigimundos y al señor Ribera mis encomiendas y contando nuestro señor. E de Madrid primero de agosto de 158

Vuestro berdadero amigo para lo que mandaredes Zalico, que bien os acordaréis,

Gonçalo de Liaño ${ }^{34}$

${ }^{31}$ Sobre la personalidad de la marquesa, su capacidad gestora, su prestigio y su afición coleccionista vid. L. Fernández Martín, "La marquesa del Valle: una vida dramática en la corte de los Austrias", Hispania, 39 (1979), pp. 559-639.

${ }^{2}$ Gonzalo nunca escribe sus cartas, sino que las dicta a un secretario profesional, poniendo solo la firma de su mano. De ahí los problemas con la ortografía que antes veíamos y con otros errores posiblemente de audición, como el estando, que seguramente debiera ser es tanto.

Contadinos, italianismo, 'campesinos'.

${ }^{34}$ F. 5934 c. 119, De Gonzalo de Liaño, Madrid, 1 de agosto de 1583
LECTURA Y SIGNO

REVISTA DE LITERATURA

Vol. 4, 2009

\section{Índice}

Nieves Baranda: «Las cartas de un gentilhombre de placer: Gonzalo de Liaño, "Trompeta en esta corte"»

Vanessa Fortuño Gómez: «Historia sagrada y loa sacramental en Calderón»

Alejandro Rubio San Román y Elena Martínez Carro: «Documentos sobre Jerónimo de Cáncer y su familia (parte II)»

Inmaculada García Gavilán: «Europa vista desde Amsterdam: Laus Urbium en la obra poética de Miguel (Daniel Leví) de Barrios»

Luciana Andrea Mellado: «Narrar el problema obrero: permanencias y rupturas en tres crónicas martianas

\section{ANTOLOGÍA POÉTICA PERSONAL: José Corredor-Matheos}

Edith Mendoza Bolio: «Los “Bocetos” de Remedios Varo»

Pablo Carriedo Castro: «Notas a un texto inédito de Max Aub: su comentario a Hombre y Dios de Dámaso Alonso (1955)»

Mario Paz González: «Un poeta y dos revistas: José María Fernández Nieto en Nubis y Rocamador»

Francisco Morales Lomas: «Los últimos días de Thomas De Quincey de Rafael Ballesteros»

Juan Carlos Merchán Ruiz: «"Roma" y "Oda a Bizancio". Humanismo culturalista en Juegos del Mediterráneo de Carlos de La Rica»

Jorge Machín Lucas: «La poética de Antonio Gamoneda: el referente esotérico»

Fidel Sebastián Mediavilla: «La poesía de Manuel Ballesteros» 


\section{RESEÑAS:}

Juan Carlos Merchán Ruiz: Elena Vega Sampayo, La poesía esencial de José Corredor-Matheos, León, Universidad, 2008, 572 pp.

César Augusto Ayuso: Juan Antonio González-Iglesias, Eros es más, Madrid, Visor, 2007, $78 \mathrm{pp}$

Mario Paz González: Raquel Lanseros, Los ojos de la niebla, Madrid, Visor, 2008, 48 pp.

Israel Muñoz Gallarte: Rafael Bonilla Cerezo, Suspirando a Musidora. Ensayos de literatura y cine, Córdoba, Diputación de Córdoba, 2008, 378 pp.

Diego Simini: Felipe B. Pedraza Jiménez, Estudios sobre Rojas Zorrilla, Cuenca, Ediciones de la Universidad de Castilla-La Mancha, 2007 (Corral de Comedias 21), $356 \mathrm{pp}$.

Gloria Llevet Planas: Juan de Arguijo, Poesía completa, ed. de Oriol Miró Martí, Madrid, Cátedra, 2009, 308 pp.

Desirée Pérez Fernández: Fidel Sebastián Mediavilla, La puntuación del Quijote (1605 Y 1615), Vigo, Editorial Academia del Hispanismo, 2008, 160 pp.

Juana Castro: Balbina Prior, Timos de la edad desnuda, Madrid, Sial, 2008, 56 pp.

Juan Manuel Fernández Álvarez: Mario Paz González, La obra literaria de Gabino-Alejandro Carriedo, León, Universidad, 2008, 538 pp.

Desirée Pérez Fernández: Diego Hurtado de Mendoza, Poesía completa, edición, introducción y notas de J. Ignacio Díez Fernández, Sevilla, Fundación José Manuel Lara, Clásicos Andaluces, 2007, CIII más 694 pp.

Cristina Collazo Gómez: José Montero Alonso, Antología de poetas y prosistas españoles. Edición facsímil con prólogo de José Montero Reguera y Alexia Dotras Bravo, Vigo: Tórculo Artes Gráficas, 2008, 450 pp.

Mario Paz González: Héctor Castilla y Cristina Morano, (eds.), Hache 5 (mayo, 2008), $112 \mathrm{pp}$.

Juan Carlos Merchán Ruiz: Joseph Roth, Cartas (1911-1939), edición y notas de Hermann Kesten, Barcelona, Acantilado, 2009, 685 pp.

al amo subrayando la soledad que se siente por su ausencia y que solo por imposibilidad no se va a verle ${ }^{27}$

Serenísima señora

Estoy muy gozoso con dos cartas que tengo vuestras y tráigolas comigo, y publicando en esta corte el fabor y la merced que me hazéis, y en lo que toca a publicar vuestro balor y hermosura y discreción. Aunque su Magestad es preguntador y quiere saber mucha particularidades, y se huelga de saber la ley ${ }^{28}$ que tengo con V. A., particularmente con estas señoras de la corte, que cada día nunca me dexan, porque son curiosas de saber vuestro trato y valor. Y la Marquesa del Valle, que es muy amiga y os desea mucho servi por averle yo contado de vuestra virtud bondad y hermosura y discreción, os quiere tanto syn averos visto. $\mathrm{Y}$ así estando anoche con ella hasta las doze de la noche, me dio un pañiçuelo de cadeneta para mý y también unos guantes, y pienso que me los dará. Yrán con este hordinario ${ }^{29}$ para que veáys las curiosidades de esta corte. Este presente es de Gonzalico, vuestro amado, que syempre va publicando vuestro valor. Y barrunto que estoy enamorado de vos, y esto lo digo entre mí y vos y no lo sepa el Gran Duque, porque los amores sy no son secretos, no son estimados. Y particularmente de los guisadicos y regalos que me dábades, bien tengo entendido que me llamáis a la comida quando coméis y cenáis y lo mismo hago yo. Dios me dexe veros muy presto, que ya esta corte me cansa sy la Marquesa del Valle no me remediase, que la verdad que diga también estoy enamorado de ella, porque ella lo mereçe y muger espiritual y discreta no la ay en esta corte syno ella. Y si queréis preguntar quién es, ynformaos del Gran Duque, que ella conoce muy bien. $\mathrm{Y}$ porque haze calor $\mathrm{y}$ ay falta de agua en esta tierra, no os quiero enfadar sino que me conservéis en vuestra gracia y del Gran Duque y del Marquesico que harto he hecho con el Rey para que acabe su negocio, y creo que se acabará, porque el Rey tiene muy gran voluntad de daros gusto. Y daréis mis besamanos a la señora Peregrina y que si ella es pelegrina, yo soy esclavo y peregrino hasta que la vea; y de las Princesas, mis señoras, que las guarde Dios mill años; y el señor Jacopino, que hartas vezes sospiro por él; y Ribera y Sigismundo, que les beso las manos. De Madrid a xxiiij de abril 1583

A su serenísima señora, para lo que mandáredes Gonzalico, vuestro amigo verdadero,

Gonçalo de Liaño ${ }^{30}$

${ }^{27}$ Cf. F. Bouza, “La estafeta...", art. cit., pp. 112-114, cartas de Magdalena Ruiz y Agustín Profit al duque de Alba; también es un rasgo risible de algunos enanos en los libros de caballerías, vid. J. M. Lucía Megías y E. J. Sales Dasí, “La otra realidad social en los libros de caballerías castellanos. 1 Lo enanos", Rivista di Filologia e Letterature Ispaniche, V (2002), 9-23. Se advierte diferencia entre el estilo y el de Francesillo de Zúñiga, mucho más hiriente y comprometido; o las de Manuel Gómez, muy posteriores, que edita F. Bouza, art. cit.

Ley: 'lealtad, 'fidelidad'.

${ }^{29}$ Hordinario, por 'correo ordinario' con el que pensaba Liaño mandar su carta.

${ }^{30} \mathrm{ASF}, \mathrm{MP}, 5933 \mathrm{f}$. 171r.-v.

LECTURA Y SIGNO, 4 (2009), pp. 9-33 
abía hallado muger que tan gran pecho como tenéys, que bastáys gobernar todo un mundo, y en entretener tantos príncipes que han pasado por Florençia, y los regalos y caricias que les abéys hecho, particularmente al Arciduque y a la condesa de Olibares. Y cómo os llamaba "serenita" y las caricias que hacéys a las princesas. También le dixe la muerte del príncipe y el regalo que tube y icistes todo lo ynposible; y que estubistes mala del sentimiento que ycistes, que vuestra alteza y el granduque los daba de comer de su mano; y que fuystes la Anunçiada de Florencia bendita y cómo a suplicar que le diese salud. También le dixe cómo coméis juntos y cenáis yuntos y que quando el Gran Duque ba, acabáys con él siempre. Preguntóme que en las villas en qué pasabays el tiempo. Yo dige que jugabays algunas veces con el Gran Duque al xiquete, y otras muchas cosas que por no ynportunar no las digo. Solo os digo que yo soy tronpeta en esta corte, que doy boces publicando lo que merecéys y lo que hazéys a todos los cortesanos desta corte y señoras, que son las mayores bachilleras de preguntarme por vuestra alteza. $Y$ algunas señoras me quieren dar algunas cosas quando yo parto desta corte.

El negocio del Marquesico ablé a su Magestad y le besé las manos de parte de vuestra alteza, que se me abía olbidado, y me dixo que lo mandaría despachar qu'él no tenía culpa, sino el cardenal de Aranbela ${ }^{25}$, que lo despacha; creo que lo despachará.

Quéntame vuestra alteza la buena vida que buesa alteza se ha dado con el Gran Duque mi señor en el estado de cena, del buen cabrito y faysanes y del buen bino y otros bocaditos regalados que se han comido, que al seguro que quando me leýan la carta, sospiraba y dábame v.m. apetito. Que si tubiera alas para bolar, bolara como alcón por beros y por comer de aquellos regalos que me dize en la carta de vuestra alteza. Plega Dios que Dios os quarde mill años como bos deseáys y bueso amigo Gonçalito, que os lo desea, y os dé un ijo de bendición, que es lo que deseamos todos los que somos vuestros criados. Y porqu'es tarde y me llaman para cenar mi amigo el embaxador, no escribo más, sino que me concedáis vuestra gracia y las princesas y de las señoras Peregrinas. Y de mi amigo el señor Ribera me recomiendo, que sabe Dios cómo yo querría yr dentro esta carta, y me pesa de no poder acerlo haora y pagar la buena boluntad que me tenéys. De Madrid xv de abril de 1583 años, su berdadero amigo para lo que me mandays. Gonçalo de Liaño. ${ }^{26}$

Tiene particular tono jocoso una carta un poco posterior, donde declara su amor a la Gran Duquesa. Se trata de una fórmula frecuente entre los bufones de ese tiempo para provocar la risa, porque es la que utiliza Magdalena Ruiz con el Duque de Alba cuando le dice que desea darle cuatro besos. Asimismo es habitual encarecer 
Perdóneme, señora, porque no la escrivo más largo, porque me quiero ir a ber al cura de Carbanchel23, porque en esta corte no me dexan y estas campanas quando tañen a muerto me congojan. A mi espeçial amiga mi señora Pelegrina, y al señor Marquesico, y a la Prinçesas y al hijo del señor Pablo Jordán; que Dios me libre de la negra, que no estoy olvidado de la fuerça que tiene; $\mathrm{y}$ a Madalena y a Elena, la vieja la que os viste, $\mathrm{y}$ a todas las damas y al señor Ribera, que es el que ha de ser coronista desta carta; y el caballero Espina su paje. Y buenas noches os dé Dios y a mí me libre Dios del espíritu que me hizo cagar de miedo la noche que dormí en palaçio. Y por no ser enportuno aunque sé yo que mis cartas no os enfadan. El sábado de Madrid a xv de henero de 158iij.

Vuestro verdadero amigo para lo que me mandáredes,

Gonçalo de Liaño $0^{24}$

Para Liaño 1583 fue año de estancia en Madrid, al menos hasta septiembre, cuando ya está preparando el viaje de vuelta a Florencia con los últimos encargos. En ese período escribe once cartas a la Gran Duquesa y cinco, al menos, al Gran Duque. Aunque casi nunca falta la mención de las gestiones encomendadas, estos temas tienen atención preferente en las cartas dirigidas al Gran Duque, por lo general más extensas. En las destinadas a Bianca Capello, se incide sobre todo en su función de pregonero del prestigio de la duquesa: su belleza, bondad, generosidad, grandeza de la corte, etc. Subraya sus relaciones en la corte española para dejar claro que esta divulgación se hace en los foros aristocráticos, los del poder en definitiva, lo que le sirve a Liaño a la par para encarecer su propia importancia y función para la Gran Duquesa, un valor que puede ser traducido en términos económicos a través de peticiones de dinero como debida recompensa. Nuevamente el envoltorio de estos elementos fundamentales son los recuerdos y exaltación de la vida en Florencia, además de esa devoción cortesana que le rinde.

Sereníssima señora.

Dios os guarde mill años por el fabor que me hacéys en escrebirme y en acordaros de vueso amigo Gonçalo, que tanto os desea servir. Y el rey a gustado de la quenta que [he] dado tan buena a cosas que tocan a vuestra hermosura, que me ha preguntado tanto particulares cosas. Yo he dicho de vuestro valor y discreçión y lo que os queréys y que no

${ }^{23}$ Se trata de un personaje que menciona en varias de sus cartas y que posiblemente fuera conocido de Liaño, ya que no lo encuentro documentado como personaje folclórico.

${ }^{24}$ ASF, MP, 5931 f. 455. 
[guarde] la sereníssima persona de V.A. como su amico Salico lo desse [desea]. De Génova a 12 de noviembre 1582

Bueso amico vedadero que buesos pies y manos bessa muy cieto

Gonçalo de Liaño

Pasado un tiempo breve, el 15 de enero de 1583, escribe para asegurarle que está llevando a cabo sus encargos y sobre todo para recordar cómo ha sido de placentera su estancia en Florencia. A través de la descripción de esas bromas, atisbamos al bufón en el ejercicio de sus funciones cortesanas

Sereníssima y verdadera amiga:

Porque vuestro amigo Gonçalico ha llegado a esta corte a ocho del mes de henero, a mediodía allegué a esta corte y me apeé en casa del señor Bartolomé de Santoyo, ${ }^{18}$ y començé ha hazer la embaxada que me encomendastes. Sabe Dios cómo yo quisiera yr dentro desta carta, con que yo os pudiera hazer reýr con los muchos quentos que en esta jornada me ha acontecido. Aunque mi señora doña Ana se holgó tanto con el presente y con la carta que la escribistes y está tan desseosa y alborotada de abelladado ${ }^{19}$ una amiga tan grande como bos; y me remito a que ella os escriva y os [dé] relaçión del desseo que tiene d'escrivir. Yo boy tomando lengua ${ }^{20}$ desta corte; no estoy olvidado de lo que me avéys encomendado ni soy yngrato, porque savé que tengo ley y os la tendré y ser coronista de vuestro balor y hermosura; y la verdá (sic) que os diga ya me muero por veros. Acordaos de Gonçalico, que aunque estoy en ausençia, no tengo quien me regale tanto como vos me avéys regalado, que en esta corte estoy publicando las muchas merced y regalo que me avéys hecho. Acuérdome de Xacopino de la Balmasía y de todas las osterías y de los vinos rojos; y también de la burla que el Gran Duque me hizo, quando estuve ocho días que no pude comer más; también sospiro por los recafidio ${ }^{21}$ y ortelanos, y aquellos bocadicos que en vuestras mesas me daban. Aquí en esta tierra me ban perdiendo el respeto, ya me llaman de vos y hallé mucha fantasía, y me muero ya de hambre. Y la ora que escrivo esto me boy acordando de que no tenía quien tanto me regalava y tanta lástima me tuvistes el día quando me dio el Gran Duque aquella medeçina, que en una copa de salsa que el señor Gerónimo, el copero del Gran Duque, me dio a beber ${ }^{22}$.

${ }^{18}$ Bartolomé de Santoyo estaba a cargo del guardarropa real y su hermano Sebastián era secretario de Felipe II; "mi señora doña Ana", a quien luego menciona, era Ana Liondegardo de Zárate, esposa de Bartolomé.

${ }^{19}$ Abelladado: Posible errata por "haber hallado", con aglutinación de vocales.

${ }^{20}$ Lengua: en el sentido de 'informe' o 'noticia', que recoge Autoridades.

${ }^{21}$ Transcripción españolizada o más bien fonetizada del término "beccafico", curruca mosquitera

becafigo o papahigo, es decir, un pajarillo que se comía.

${ }^{22}$ Por otras cartas sabemos que lo que le dieron fue un laxante.

\section{LAS CARTAS DE UN GENTILHOMBRE DE PLACER: GONZALO DE LIAÑO,} “TROMPETA EN ESTA CORTE”

\section{NIEVES BARANDA}

UNED

"la buffoneria è vita et anima de la corte" (Pietro Aretino)

En una carta de 1583 Gonzalo de Liaño le asegura a la Gran Duquesa de Toscana, Bianca Capello: "Solo os digo que yo soy tronpeta en esta corte, que doy boces publicando lo que merecéys y lo que hazéys a todos los cortesanos desta corte y señoras". En el Renacimiento el mundo se había vuelto un poco más pequeño, el coleccionismo, la necesidad de noticias, de novedades, la búsqueda de información "Esta investigación ha sido posible gracias a la financiación del MEC a través de su programa de
estancias breves en centros extranjeros. Es un anticipo de la edición que preparo del epistolario. Recibido: 22-02-2009 Aceptado: 13-04-2009 
desde lugares alejados era más urgente y Gonzalo de Liaño sirvió a estos propósitos para el rey Felipe II. Trajo o llevó entre Italia y España gallinas "de pelo enrizado", gámbaros o gambas, perros de Irlanda, caballos, ballestas, un leopardo (murió durante el viaje en las proximidades de Barcelona), simientes y bulbos de algunas plantas, aceite medicinal para las muelas, otro para el estómago, fruteros, reliquias, cuadros y otras piezas de arte, piedras preciosas, imágenes de las villas florentinas con sus jardines, y muchos más objetos, documentos y cartas. Además era portador de noticias, relator de chismes, cimentador de famas y difusor de la cultura de unas cortes en otras, dando cuenta de novedades, modas, costumbres, actitudes, protocolos. Su condición de embajador informal y agente real le permitía cumplir con flexibilidad muchas funciones.

No fue un personaje único en este aspecto. Hay que pensar en muchos otros que cumplían cometidos semejantes a lo largo de los difíciles caminos europeos, pero éste de modo excepcional era un enano bufón que nos ha dejado un inestimable epistolario en testimonio de toda esta actividad. El interés de este atractivo y extenso conjunto de cartas, conservado en el Archivio di Stato di Firenze, es múltiple, porque añade información a las estrechas relaciones políticas entre el rey Felipe II y la Toscana, pone fecha y trámites a la adquisición de varias obras de arte italianas hoy en el Escorial, subraya el interés personal del rey español por estos temas a través de su detenido seguimiento, nos da atisbos sobre el complejo mundo de los agentes artísticos y los embajadores informales y not least nos proporciona, a los historiadores de la literatura y la cultura, una de las muestras más extensas y ricas del discurso epistolar bufonesco en la época. ${ }^{1}$

Sobre el personaje como agente artístico vid. Salvador Salort y Susanne Kubersky-Piredda, "Art Collecting in Philip II's Spain: The Role of Gonzalo de Liaño, King's Dwarf and Gentleman of the Bedchamber: part I" The Burlington Magazine, CXLVIII (2006), pp. 660-665; y parte II en idem, CXLIX (2007), pp. 224-231; como corresponsal bufonesco N. Baranda, "Las epístolas bufonescas de Gonzalo de Liaño a la gran duquesa de toscana", en Actas del XVI Congreso de la Asociación Internacional de Hispanistas, en prensa, artículo al que remito para cuestiones generales sobre el epistolario y su autor. tenían fama de V.A., ustavan [gustaban] la buena reaçion [relación] que yo dava, aunque yo tenía maa [mala] lengua y maa de entendé, conoçían que yo tenía le [ley] a V.A. y a gan duque, mi amico. Y esto lo vea V.A., como me vea en España, que su amico Salico tenere la le [ley] como soi obligado a una casa tan prinçipa como es la de V.A.

Yo vine a La Especia y me embagué [embarqué] en una fagata con unos vientos fuetes [fuertes] y assía [hacía] ir las veas [velas] a agua, que pensava que no avía de havé má Salico y dexa la embaxara [embajada]. Y en cuato [cuatro] días que vine de La Speçia, vine d'aquí a Génova con artas paura11, poque hazían la vea [vela] a gusto de los maineros, y con esto me consoava [consolaban]: "No habete pauras". Y yo despondía [respondía]: "No tego paura sino de aogame [ahogarme]". Y también acodándome de la pofesia [acordándome de la profecía] que el gan duque me dixo, que me avía de aoga [ahogar] ante que aiegase [allegase] a España. La senoa Leia de negon ${ }^{12}$ basa [besa] la mano a V.A. y al gan duque y al cadenal [cardenal] ${ }^{13} \mathrm{mi}$ amigo que amanecho [me han hecho] mucho favó y regalo por espeto [respeto] de V.A., particulamente el embaxado de su magestad que tan sevido [servidor] es de V. A. y el cadenal Alexandino que está aquí espedando [esperando] al encomendado mayor paa [para] negoçiá los negoçios de su hemano.

Muchas cosas podía escivir [escribir], sino que el secetario y notado [notario] se cansan. Solo os pido que me concebes [conservéis] en vuestra graçia y de la señoa Pelegina ${ }^{14} \mathrm{y}$ del gan duque mi amigo y el cadenal, de meçer [micer] y Jacopino, el de la Mavasía [Malvasía], que quería navegá dento de su hostera ${ }^{15}$ asta España; y el maquesico ${ }^{16}$, que Dios le guade como V.A. lo desea; y mi epeciá amigo Pospeo Colona [Próspero Colonna] ${ }^{17}$ que no puero [puedo] dexa de acordame dónde yo esçebido [he recibido] tanto favo de su casa. Y quando estava enojado, él me quitava la coloa [cólera] y el señó don Joan de Meçes [Juan de Medicis], que aunque me pelava las babas [barbas], no puero [puedo] dexa que V.A. me lo rencomende [recomiende]. Y porque siio [ihe sido?] muy enfaroso [enfadoso] en esta cata [carta], no digo más, sino que N[uestro] S[eñ]or guade

${ }^{11}$ Paura, italianismo, 'miedo'. El viaje que describe Liaño era desde Florencia por tierra hasta La Spezia

y de ahí a Génova.
${ }_{12}$ La señora Leia de ....: sin identificar.

${ }^{12}$ El cardenal es Fernando de Medici, el hermano de Francisco I, para quien Gonzalo también hacía de ${ }^{13}$ El cardenal es

intermediario

Señora Pellegrina: era la hija mayor de Bianca Capello, fruto de su primer matrimonio.

${ }^{5}$ Hostería. Son varias las veces que Liaño se refiere a micer Jacopino, dueño de la posada u hostería "La Malvasía", en Florencia y a su buena comida allí.

"Marquesico, es decir, Antonio de Medici, el joven marqués, hijo de Francisco y Bianca, nacido antes del matrimonio de sus padres y futuro heredero. A la muerte de Francisco I y Bianca, el cardenal Fernando, sucesor del ducado, descubrió sospechosamente una trama que desvelaba que Antonio no era hijo de Francisco y Bianca, sino el fruto del parto de una campesina, que ella había hecho pasar por hijo propio a fin de ofrecer al duque el ansiado heredero, atándolo definitivamente a ella. Vid. C Giachetti, ob. cit., y Guglielmo Enrico, “Della morte di Franceso I de'Medici e di Bianca Cappello relazione storica", Archivio storico italiano, XVIII (1863), pp. 19-81. Liaño alude en muchas cartas al deseo de Bianca de tener un hijo y en ocasiones a noticias sobre sus embarazos, que siempre resultaron ser falsos.

${ }^{17} \mathrm{El}$ anciano cardenal Granvela era entonces secretario de estado en sustitución de Antonio Pérez.

LECTURA Y SIGNO, 4 (2009), pp. 9-33 
diciembre de 1579 y le da cuenta de todas las gestiones realizadas en su favor, así como de los encargos recibidos. Respecto a la Gran Duquesa solo dice entonces: "Suplico a V.A. dé un recado a la Gran Duquesa, mi señora, y que estoy aquí para servilla" .8

En 1582 Gonzalo, al servicio de Felipe II, vuelve a Florencia y pasa allí algunos meses entregado a sus gestiones, como era habitual. Sus tratos en la corte incluyeron esta vez de forma bastante cercana a Bianca Capello, con quien advierte que es necesario seguir manteniendo las mejores relaciones. Para ello, apenas ha abandonado la ciudad camino de España, le escribe una carta solo para darle noticia jocosa de sí mismo, apuntar su función de propagador de fama y prestigio y hacerle recordar su presencia palaciega. De momento la carta no trasluce intereses concretos, sino tan solo la voluntad de conservar el vínculo a través del cual en un futuro pueda encauzarlos. ${ }^{9}$

\section{Sereníssima señora, vueso amigo Gonçalico:}

Porque sé que mi carta será bien recibida conoçiendo el bien que he reçibido de V.A., y porque no me tengáis por desconoçido, os escribo dando cuenta de mi vita lo primero prinçipal. Salí el día que pati [partí] del pox. (sic) aquea [aquella] noche logo sentí la soedad y començé a entiteçerme, no viendo que me davan en la balca [barca] de mamar, quando V.A. me sodía [solía] regala con aqueios duçe bocaos y particulamente cuando me dava algun recafidio hu orteano ${ }^{10}$. Y aunque V.A. me iama "Salico" y otas nonbes [otros nombres] que me ponía, que todo era queerme bien V.A. Y assí boi pubicando el valor de V.A. y su hermosua, disquiçion [discrección], que mucha gente que ha iado [he hallado] en Génova, cavaieros principales me preguntavan por V.A., que anque [aunque]

Dado lo caótico de la ortografía de las cartas, que emplea diversas manos profesionales, regularizo levemente su uso acercándolo al actual, con diversas intervenciones según el grado de pericia del secretario, ya que cuando son italianos escriben un español por aproximación fonética de lectura muy dificultosa.

ASF, M.P., 5931 ff.. 101-102r. El escribiente es italiano y transcribe el castellano con graves errores a partir de la audición del dictado. Algunos de ellos son sistemáticos, por ejemplo, la omisión de la final de sílaba o de la $l$ intervocálica. Este problema aparece en otras cartas, si bien no de forma ta acusada. Lo más frecuente es el uso de italianismos crudos en el texto.

${ }^{10}$ De otras cartas se deducen los italianismos beccafichio y ortolano. Son pequeños pájaros comestibles, la oropéndola (también papahigo) y el escribano hortelano, que en la correspondencia parecen ser la debilidad gastronómica de Liaño. El diccionario de Autoridades señala del becafigo: "es comida sabrosa en el tiempo que hai higos y se mantienen de ellos" y del hortelano: "Se llama también cierto paxarito semejante al gorrión, que se ceba con leche y harina, y se pone tan gordo y delicado que es comida muy regalada"
Efectivamente, basta asomarse siquiera al tema para saber que son muy escasos - y no solo en España - los testimonios directos de bufones del período, si bien se conocen, gracias a fuentes indirectas o literarias, sus gracias y técnicas para provocar la risa o sus relaciones con los poderosos a quienes servían. En este aspecto es muy relevante la correspondencia particular de Felipe II, que alude a ellos en bastantes ocasiones y que los consideraba parte del círculo familiar más estrecho. De hecho, Gonzalo de Liaño aparece citado en esas cartas con los diminutivos afectivos que tanto se empleaban para estas gentes menudas, porque seguramente fuera un enano: "vuestra hermana se hace tahúr de un nuevo juego que ha traído Gonzalillo".2 A pesar de ese conocimiento de los personajes y de saber que participaban del gusto por el intercambio epistolar que manifiesta toda la buena sociedad de la época, son escasísimas las piezas que conservamos en España $^{3}$ y en Italia, salvando los excepcionales diarios del bufón Atanasio, que sirvió en la corte de Urbino entre 1539 y 1564 , los testimonios directos son igualmente escasos ${ }^{4}$. Frente a esta penuria de las fuentes directas, el conjunto epistolar de Liaño es ciertamente excepcional y sobrepasa cualquiera de los conocidos, al superar la centena de cartas. De ellas, cincuenta y dos son para la Gran Duquesa y el resto para su marido, escritas entre el 18 de enero de 1580 y junio de 1588, si bien las cinco de ese último año están destinadas al Gran Duque Fernando I, ya que Francisco I, su hermano, había muerto

Su calidad de bufón había sido conjeturada por F. Bouza a partir de estas menciones, vid. Cartas de Felipe II a sus hijas, ed. de F. Bouza, Madrid, Akal, 1998, p. 125.

${ }^{3}$ F. Bouza, edita siete de las conocidas, vid. "La estafeta del bufón: cartas de gente de placer en la España de Velázquez", Madrid: revista de arte, geografía e historia, 2 (1999), pp. 95-124. A estas hay que anadir las doce de Francés o Francesillo de Zúñiga, en Curiosidades bibliográficas. Colección escogida de obras raras de amenidad y erudición, Madrid, M. Rivadenayra, 1855 (BAE, 36); y las del doctor Villalobos, Obras, Madrid, SBE, 1886. Sobre estos personajes vid. el estudio imprescindible de José Moreno Villa Locos, enanos, negros y niños palaciegos: gente de placer que tuvieron los Austrias en la Corte Española desd 563 a 1700, México, La Casa de España en México, 1939.

Estudia los diarios del bufón Atanasio Tito Saffioti, ...e il signor duca ne rise di buona maniera: vita privata di un buffone di corte nella Urbino del Cinquecento, Milano, La vita felice, 1997; a partir de citas en epistolarios y otras fuentes, dan mucha información de interés Alessandro Luzio y Rodolfo Renier "Buffoni, nani e schiavi dei Gonzaga ai tempi d'Isabella d'Este", Nuova Antologia, serie III, vol. XXXIV, 16 de agosto (1891), pp. 618-650 y 1 sept. 112-146; también dedicado a los Gonzaga Giancarlo Malacarne, Le feste del principe: giochi, divertimenti e spettacoli a corte, Mantova, Il Bulino, 2002, pp. 165191, en particular; sobre Francia especialmente A. Gazeau, Historias de bufones, Madrid, Miraguano 995.

LECTURA Y SIGNO, 4 (2009), pp. 9-33 
en octubre del año anterior. Los lugares de procedencia siguen los desplazamientos de Liaño entre Florencia y Madrid, con algunos viajes por Italia, ya que escribe solo cuando se encuentra fuera de la corte granducal (Génova, La Spezia, Roma, Mantua, Barcelona, Valencia, Monzón, Madrid), e incluso una vez desde la misma Florencia pidiendo permiso para desplazarse a pescar fuera de la ciudad. Por otro lado, de las cartas y otras menciones documentales fuera del epistolario, se desprende que Liaño también escribía a Felipe II, pero esa correspondencia, si se conservara, estaría por localizar.

Gonzalo de Liaño, el enano Gonzalillo, Gonzalico o Zalico, no era un hombre común. Tenía una inteligencia aguda, gran conocimiento del mundo cortesano, capacidad organizativa, valor, carácter, don de gentes, gusto artístico y quizá hasta dominio de otras lenguas. Cuando el emperador Rodolfo II estuvo en España entre 1564 y 1571, Gonzalico fue uno de sus criados y luego fue recomendado por Hans Khevenhüller, embajador imperial, a la emperatriz María en una carta:

El personage que la presente dará a V.Mag. es don Gonçalico, gran criado de su Magd. Cathólica y que lo fue tanbién de su Mag. Cesárea [Rodolfo II] al tiempo que estuvo en estos regnos. Suplico a V. Magestad lo conozca por tal y para mandarle tratar por esto y las otras buenas partes que le sobran y faltan como él merece, que todo esto y por la affición que por lo mismo le tengo han sido parte para encomendarlo a V. Magd....5

No era raro que los bufones reales provinieran de las cortes nobiliarias, por lo que podríamos suponer que ese fue el camino seguido por Gonzalo hasta llegar al servicio directo de Felipe II. Sin embargo, sus cualidades le hacían valioso mucho más allá de los reducidos quehaceres del bufón doméstico, y Felipe II supo sacar partido dándole cometidos de agente en el exterior. Así, al menos desde 1579,

Apud Cartas de Felipe II a sus hijas, ed. de F. Bouza, Madrid, Akal, 1998, p. 125 en nota y con información personal que le agradezco. La destinataria es la hija de Carlos I y María de Austria, que volvió a España en 1582 después de pasar gran parte de su vida en Bohemia; entonces se recluyó en las Descalzas hasta su muerte en 1603. La llegada de los bufones y locos a la corte real solía hacerse pasando previamente por el servicio de casas nobiliarias, vid. F. Bouza, ob. cit., pp. 41-46; sobre este importante embajador vid. Sara Veronelli, "La historia de Hans Khevenhüller, embajador cesáreo en la corte de España", en J. Martínez Millán, dir., Felipe II (1527-1598). Europa y la monarquía católica Madrid, Parteluz, 1998, pp. 517-537 aparece en los registros escritos florentinos como bufón y mensajero real, encargado del transporte de un cuadro para el rey de España. La correspondencia que mantiene Liaño con los Grandes Duques responde, por tanto, a esa función asignada desde la corte española, en un continuo ir y venir de intereses prácticos entre Florencia y Madrid: la obtención de un título para el hijo de Francisco I, el traslado de un escritorio de regalo, el encargo de un cuadro, etc. Si en las cartas se limitara a tratar estos encargos de forma práctica, no pasaría de ser una más de las colecciones epistolares de embajadores, representantes o agentes diversos que tan útiles resultan para el historiador, sin embargo en estas hay mucho más, porque todos los cometidos se disfrazan bajo el espíritu de la bufonería, empleada como medio de abrir puertas y caminos al interés. En este aspecto, quizá la demostración más clara de cómo le sirve a Gonzalo de Liaño su condición de enano y hombre de placer es el epistolario con Bianca Capello.

Bianca Capello era la bella hija de una noble familia veneciana. A los quince años, en 1563, huyó con su amante, se casaron y se instalaron en Florencia, donde llamó la atención de Francisco, entonces aún heredero del ducado. En el verano de 1564 nace su hija Pellegrina y a finales de ese mismo año se convierte en amante de Francisco I, ya duque debido a la abdicación de su padre, Cosimo de Médici. Aunque al año siguiente Francisco se casa con Juana de Austria, Bianca continúa siendo su amante hasta la boda de ambos el 5 de junio de 1578 en el palazzo Pitti, apenas dos meses después de que Franciso enviudara. Gonzalo de Liaño aparece en Florencia un año después de esas bodas, porque en 1579 se le menciona en un documento de 31 de agosto, identificándole como bufón del rey de España y se le encarga el traslado de un cuadro, regalo del Cardenal Fernando de Médici a Diego de Córdoba, jefe de caballerías del rey ${ }^{6}$. Él mismo, en una carta muy formal de 18 de enero de 15807, dirigiéndose al Gran Duque, afirma que llegó de regreso a la corte española a 26 de

${ }^{6}$ Apud S. Salort y S. Kubersky-Piredda, art. cit., 2006, p 660, n. 2.

Todas las cartas citadas y editadas provienen del Archivio di Stato di Firenze, fondo Mediceo de Principato, en adelante, ASF, MP; aquí 731, f. 20r.-21r.

LECTURA Y SIGNO, 4 (2009), pp. 9-33 

sobre otros lugares mil
de cánticos, salmos e himnos
que persuaden a servir
a Dios con exaltaciones.
Bien debemos inferir
en la luz de aquella sombra,
que le place ver aquí,
con devotos regocijos
sus grandezas aplaudir,
pues no sin causa previno
el que hubiese risa allí.
(Loa de La vacante general, p. 470.)

Este último pasaje demuestra, por otro lado, el uso argumentativo de las contadas prefiguraciones que, en forma de mención, aparecen en las loas sacramentales $^{27}$. Otro ejemplo de ello sería el uso que el Peregrino de la loa de $E l$ indulto general hace de Daniel 2, 32-35 en su disputa con el Demonio:

$$
\begin{aligned}
& \text { DEM. - Sí pero ¿qué piedras traes? } \\
& \text { PEREG. - A mí, que yo soy la Piedra } \\
& \text { del Monte del Testamento, } \\
& \text { que vió postrada y deshecha } \\
& \text { allá en Nabuco la estatua } \\
& \text { de tres metales compuesta. } \\
& \text { (Loa de El indulto general, p. 1720.) }
\end{aligned}
$$

Esta función argumentativa de las intervenciones constituidas por citas bíblicas de distintos tipos es al mismo tiempo - a causa de su cometido persuasivo con respecto a los otros personajes - argumental, pues contribuye a hacer avanzar el texto. En muchos casos, asimismo, son versos que cumplen una tercera función, la alegórica, porque iluminan el plano historial para que veamos el significado alegórico de la circunstancia; por ejemplo, remiten al verdadero sentido del juego de prendas de la loa de El verdadero Dios Pan:

$$
\begin{aligned}
& \text { VERD. - Esperad, que, en el principio, } \\
& \text { la Poesía ha errado. } \\
& \text { POES. Es cierto, }
\end{aligned}
$$$$
\text { pues en el principio, dije }
$$

${ }^{27}$ A diferencia de los autos, no hay en estas piezas una alegorización de los hechos del Nuevo Testamento a partir de la teatralización de personajes y sucesos veterotestamentarios. mesmo día azerté a yr yo a la comida y llego tarde, y como llego, bi a mi amigo Gonzalillo y me contó lo que abía pasado, de manera que como bi lo que abía pasado con Gonzalillo, más quisiera ser en vuestra mesa que allí, porque también ubo la parte mía para mí. De manera que Gonzalillo fue más baliente, porque el barón ni todos aquellos caballeros no fueron bastantes para quitarle que no arremetiese a él, y le sacudió tan bien que fue el otro más malparado de mí. Luego se yzieron las pazes por orden de aquellos caballeros que allí estaban y como no soi muy baliente, luego se confirmaron las pazes. D’allí a tres días bolbí a la comida del Duque y el señor loco tomó un laúd qu'es del Conde de San Román, qu'está aquí arto biejo, me sacudió con él de manera que ya sol músico de laúd. Otro día siguiente, qu'es el mesmo día, por un no sé qué que dije al Prínzipe de Oria, que fue que estando jugando Gonzalillo con él a piquete, le dije que para entretenerse era bueno Gonzalillo, que no yo quería jugar con él, porqu'era para destruylle" 46

Durante esos viajes sigue escribiendo a la Gran Duquesa. Su confianza epistolar se estrecha y las cartas reflejan una de las fórmulas jocosas que debían ser comunes entre la bufonería y sus señores: la del vínculo amoroso entre ambos. Gonzalo, desde su condición de enano y precisamente por el contraste físico con la dama, que a los ojos de todos convierte el amor en imposible y produce hilaridad, se refiere en ocasiones a la duquesa como su amor "a lo divino". Con él abre la siguiente carta, que luego trata sobre la eficacia de sus gestiones, dando detalles concretos de lo hecho y remitiendo a terceros que pueden dar fe de ello. Efectivamente el único medio que tenía Gonzalo para demostrar su posición en la corte y su proximidad al rey era la confirmación que podían aportar otras personas del mismo entorno, de ahí que sea frecuente la mención de gente de confianza de los Grandes Duques como testigos de su actuación. Esta exposición de su amor y trabajo le lleva en la última parte de la carta a poder reclamar pago en efectivo y a quejarse de la tacañería del Gran Duque, que menciona sin rebozo alguno.

\footnotetext{
${ }_{46}^{46} \mathrm{Ibidem}$ ff. 421r-422v; carta de Arandilla al Gran Duque desde Villafranca, 12 de febrero 1585.
}

LECTURA Y SIGNO, 4 (2009), pp. 9-33 
A la Serma. señora la Gran Duquesa de Toscana, mi sra. ${ }^{47}$

Por hacer pesar al gran duque os quiero escrivir desta manera, amor mío a lo divino. Una carta me dio Luis de Ovada ${ }^{48}$, que aunque estava yo triste y muy penoso de la enfermedad de mi muger, me dio tanto contento que se me alegró el coraçón y con las dulçes palabras que en ella me escrivís me tocó al coraçón, de manera que me quitó e dolor que yo tenía. Sepa V.A. que me debe mucho, porque he dado tan buena relaçión al Rey de V. alteza que si mucho os quería antes, mucho más os quiere aora. Y la embaxada está muy bien hecha, de manera que la Marquesa del Valle no se quexará y remítome al Sr. Luis de Ovara, que dirá a V. alteza quién es Gonzalico, y lo que yo merezco, y la reputación y fama que he ganado más que nunca, que anoche me dio un laxarico ${ }^{49}$, un poquito de pan pringado y me dixo que le dixesse cómo me sabía. Y dixe que me sabía bien y mandóme traer a beber, que estos regalos no se hazen a todos ${ }^{50}$. De las ferias ${ }^{51}$ sobre la mesa y el escritorio yo haré de manera que el Gran Duque quede espantado, y esta le dirá V. A., que yo no lo escrivo al Duque.

Dize Luis de Ovara que mereçía yo mucho, porque sabe él lo que yo he dicho al Rey del Gran Duque, y que el Rey está muy satisfecho de V. altezas por la relaçión que yo le he dado, y que aunque el Gran Duque me diera dos mil escudos, muy poco para lo servicios que yo le he hecho por acá en esta jornada. Y todos me an preguntado, hasta el mismo Duque de Saboya, y yo les he dicho a todos que me avía dado mill escudos, y sabe $V$. alteza que no me dio sino çien escudos para traher tantas cosas como yo truxe a m cargo. Y el día que me los dio, los pagué a Baltasar Xuárez ${ }^{52}$, que se los devía, y tomé doçientos escudos a cambio, que se los pagué al dicho Balthasar; y para que V.A. lo crea, en los libros de Balthasar Suárez se hallarán. Mas por esto no he dexado yo de hazer lo que debo, mas perdóneme V.A., que es un poco apretado ${ }^{53}$ y esto no le he querido escrivir hasta aora que lo digo, que ya el Gran Duque y V. A. tendrán cartas de su Magestad en agradeçimiento del presente. Pluguiera a Dios que el Gran Duque fuera como V.A. y tan liberal, que al fin V.A. me regala y me da cien escudos cada año y me

${ }^{47} \mathrm{ASF}, \mathrm{MP}, 5940$ h. 6r-v. La carta está falta de una hoja y, por tanto sin firma ni data; no obstante se puede suponer que le corresponde el f. 25 del mismo legajo, que no pertenece a otros documentos y onde consta la firma y se fecha en Monzón a 24 de agosto de 1585, que asignamos a esta.

Luis de Ovara es el cremonés Luigi Dovara, agente mediceo en la España de Felipe II, de ahí que Liaño remita a su testimonio para asegurar la veracidad de sus palabras. Vid. Guido S. Picenardi Luigi Dovara, gentiluomo crem XLVII (1911), pp. 49-128

Laxarico. termino no aclarado.

No queda claro en el texto si esta deferencia es de la Marquesa del Valle o del Rey. En otras ocasiones se menciona en la correspondencia la presencia de Gonzalo durante las comidas de sus amos y su participación en las mismas por medio de los bocados delicados que le ofrecen, por los que él siempre afirma suspirar.

51 Ferias: regalos. Se debía tratar de un escritorio y una mesa de gran valor que el Duque regala a Felipe II y por el que espera un reconocimiento sustancial.

52 Baltasar Suárez era agente financiero en Florencia, desde donde mantenía correspondencia y relaciones con España.

${ }^{53}$ Apretado: 'tacaño'. extenso relato de la Creación en la loa de El Año Santo de Roma y que la presencia del personaje de Pablo en la loa de Llamados y escogidos, la principal función de las citas bíblicas en las loas sacramentales es servir de argumento a los contendientes de las disputas teológicas que se desarrollan en ellas. Por lo general, se procura explicar el sacramento de la Eucaristía; es el caso de la cita de unas palabras proféticas del rey David:

SAB. $-[\ldots]$

desde que por David dijo Dios, beber sangre no quiero

de inmoladas reses ya,

proféticamente viendo, que solo el de vino y pan será sacrificio eterno, cuando humanado se quede

Dios y hombre en su blanco velo:

con que queda respondido,

que el convidaros a eso

es, la que por su providencia,

de Dios previno, que siendo

la más familiar vianda,

el más común alimento,

más natural, más amigo,

y conforme al calor nuestro,

por el tedio o el hastío

nadie deje de comerlo.

(Loa de Llamados y escogidos, pp. 451-452.)

En muchas otras ocasiones se desea justificar la alegría que reina en la celebración del Corpus:

FE. $-[\ldots]$

No hay en la escritura texto

de quien se pueda argüir

Sombra y Figura de Cristo

más viva ni más feliz

que Isaac con la leña al hombro

viéndole al monte subir

del Padre a ser sacrificio;

pues si Isaac, quiere decir

risa, que es alegría y fiesta, 
de tiempo, tiene que desentrañar el misterio de la Eucaristía ${ }^{22}$, y para ello ha de primar la discusión teológica sobre la acción. Por eso, el esquema de la loa sacramental calderoniana, concretado en diferentes paradigmas compositivos, es la que Rafael Zafra denomina "estructura de cuestión", es decir, "una escenificación del método escolástico de la quaestio"23; y esa fidelidad a la concepción de las piezas como debates teológicos acaba por convertirlas - como ha visto Zafra- en más sacramentales que los autos: “En la loa se recuerda y exalta una verdad de Fe [...], y se la celebra con un auto cuyo asunto puede no tener más de eucarístico que la adoración final de la Hostia y el Cáliz"24.

Aunque Calderón no incluye "macrotextos bíblicos argumentales" en las ocho loas sacramentales que comentamos, sí recurre en una ocasión al uso de un "macrotexto bíblico parcial"; concretamente, en la loa de El Año Santo de Roma25, donde los propios Días narran la Creación. Dentro de la contienda entre la Gracia y la Naturaleza, que conforma la estructura de la pieza, este fragmento del Génesis poco modificado, por otra parte - sirve como argumento a la Naturaleza para intentar demostrar su mayor excelencia ${ }^{26}$.

Las más numerosas en las loas sacramentales de Calderón son, sin embargo, las "menciones y adaptaciones de microtextos bíblicos". Aunque, como ha quedado dicho, no es posible detenerse en la infinidad de frases extraídas de la Biblia, se debe prestar atención a las menciones precisas de personajes y hechos de historia sagrada $\mathrm{y}$, sobre todo, determinar la intención del dramaturgo al aludirlos. Al igual que el

22 "EUR.- Divina Sabiduría, / [...] / ¿Sepamos, pues, a qué efecto / nos llamas y qué convite / es el que nos has propuesto?" (Loa de Llamados y escogidos, p. 451). "APOST.- ¿Qué celebráis este día?" (Loa de La vacante general, p. 470). "DAM. 1. a $^{-}$[...] / la Fe Católica, atenta / a la mayor alabanza / de Misterio que celebra, / saber cuál es el mayor / Atributo suyo intenta" (Loa de El divino Orfeo, pp 1835-1836).

3 R. Zafra, "La «estructura de cuestión» en las loas sacramentales calderonianas", en I. Arellano y E Cancelliere (eds.), La dramaturgia de Calderón: técnicas y estructuras (Homenaje a Jesús Sepúlveda), Madrid / Frankfurt am Main, Iberoamericana / Vervuert, 2006, p. 626.

${ }^{24}$ R. Zafra, art. cit., p. 627

Vid. I. Arellano, Estructuras dramáticas y alegóricas..., pp. 85-86.

${ }^{26} \mathrm{Vid}$. Loa de El Año Santo de Roma, p. 20. socorríais con dineros. En fin vos sois mi esperança y mi consuelo. ¡Viva, viva la Gran Duquesa y también el Gran Duque, es buen amigo y compañero y da poco dinero!; y $\mathrm{X}_{\mathrm{ixumundus}}{ }^{54}$ y Ribera, que son buenos compañeros y amigos de V.A.; y a mi señora Peligrina, que es aquella que salió del paraýso terrenal cantando el alleluya. Sabe Dio cómo yo quisiera yr dentro desta carta a ver aquel rostro angelical y besar aquellas vuestra manos, que quitan quanta melanconía ay. Y porque me avéis de responder a esta carta, no digo más esperança.

Vuestro Gonçalo de Liaño.

La siguiente carta se estructura exactamente a la inversa. Primero Gonzalo le da cuenta de sus buenos oficios y le plantea un tema que aparece en la correspondencia de esa época con ella y con su esposo: la necesidad de ampliar las indulgencias concedidas a los rezos en uno de los cuadros que habían enviado desde Florencia. Sin duda se trata de un asunto de interés para Felipe II, que quiere colocar el cuadro en El Escorial, pero al que no le basta una bula privada, sino que desea hacerla extensiva a todo el que rece ante el cuadro. Para ello era necesario obtener un documento papal, que es el que se solicita por medio de los Grandes Duques. En la segunda parte de la carta, Gonzalo despliega todo su encanto de bufón para retratarse a sí mismo con su esposa parodiando los gestos cortesanos. Luego narra una breve anécdota escatológica con su hijo, del que concluye: "asta en esto ubo de pareçer a mí". La risa que estas situaciones provocarían en la Gran Duquesa se aprovecha para pedir que le envíen unas cajas con comida toscana y apuntar que hay una deuda pendiente por lo que trabaja para ellos. El interés nunca anda lejos.

Állome con una carta de vuestra alteza de diez y ocho de agosto bien ençecinada ${ }^{55} \mathrm{y}$ entendido el amor que vuestra alteça me tiene, que bien me lo deve por la affición que la tengo y la buena amistad que é echo y relación que é dado a la Marquesa del Balle de vuestra alteça, que ya me entiende. Y remítome a Luis de Obada, que ya á partido de Monçón para allá, que V. alteça se podrá informar dél lo que á echo el buen Gonçalo; y como su Magestad esté en esta corte, se conoçerá. Para el quadro que envió vuestra alteça a su Magestad gran cosa fuera que se embiara un jubileo, para que todos los que reçasen en el retrato se pudieran ganar las graçias que se conçedieron a vuestra alteça por el papa

${ }^{54}$ Xixumundus: Segismundo, al que menciona en otras cartas.

55 Ençeşinada: seca como la cecina. Es frecuente emplear expresiones propias de la comida para referirse a las cartas que han tardado mucho tiempo en llegar y que, por tanto, son viejas en su información; vid. María Montáñez Matilla, El correo en la España de los Austrias, Madrid, CSIC, 1953, pp. 91-97 para estos asuntos prácticos

LECTURA Y SIGNO, 4 (2009), pp. 9-33 
Gregorio o que se enbiase la memoria que a vuestra alteça se le concedió, porque importaría mucho. Porque el que embió el Gran Duque era para un quadro de lapidaçio (sic) chico, para la cabeçera de la cama, no se puede ganar, sino solo el Rey. Y estotro que V. alteza embió no avía de traer este capítulo, sino que le ganasen todos quantos reçasen en él, porque le daría su Magestad a El Escurial.

Ya tengo gana de yr a ver a vuestra alteza y también mi muger os desea conoçer, y diçe que no saldría d'España por ninguna manera si no fuese por amor de vos. Mas por ser tan peligrosa la yda, si no era enviar una galera por mí y por mi muger, para asegura mi onra, yo no partiera, por los peligros que ay por el camino. Es tanto el amor que os tengo y lo que mereçéis que por amor de vos me pondría a qualquiera cosa que conviniese a vuestro serviçio. Y acordándome quando os tomáis las manos vos y el Gran Duque, así lo hacemos yo y mi muger, y le digo: "Así hace el Gran Duque a la Gran Duquesa quando están comiendo", y que tan bien le saven los buenos bocados como a mí. Y es cosa de ver los amores que nos acemos y dicimos [sic]. Y mi hijo paréceme en todo, que la otra madrugada le tuve en mi cama y se me cagó en ella y biénele de casta, que asta en esto ubo de pareçer a mí. No digáis que no os doy quenta de todo. También dice mi muger y yo lo digo que me enviéis unos salsichones de Florençia y unos quesos, porque mi muger tiene gana de comer cosas de por allá. Y quiero que me hagáis una caja y se la deis a Baltasar Suárez, mi amigo, que él me la enviará, porque siendo cosa vuestra nos sabrá muy bien. Yo creo que la semana que biene me boy a Monzón, porque su Magestad me á embiado que me parta. Plega a Dios que me dé salud para que os pued servir a vos y al Gran Duque, porque ya os doy palabra que antrambos [sic] a dos me devéis arto y porque me hallo ocupado. No digo más, sino que me tenéis el coraçón robado, que mi muger me pide celos de lo mucho que os quiero que es $\mathrm{ss}^{\mathrm{a}} / \mathrm{ff}^{\mathrm{a}}$. Y de Madrid a 14 de nobiembre de 1585 años.

Vuestro verdadero amigo para lo que me mandáredes,

\section{Gonçalo de Liaño $0^{5}$}

A medida que ha ido consolidándose la confianza entre Bianca Capello y Gonzalo de Liaño, las peticiones de éste se han concretado en dinero o en gestiones ante su marido, a quien le pide que aplaque o que convenza de su inocencia en cierto negocio ${ }^{57}$. Como la corte es un espacio de poder y relaciones que pueden a su vez ser

\section{${ }^{6} \mathrm{ASF}, \mathrm{MP}, 5940 \mathrm{f} .748$}

${ }^{57}$ Así en carta de 5 de julio de 1584 le dice; “Bien entiendo que el Gran Duque tendrá cólera conmigo que le conosco su condición. Y pues crió Dios a V. A. tan clementíssima y piedosa [sic] por hacer merced a todo el mundo y bien a su Gonçalico, que la fama de V. A. en esta corte y en todo el mundo es de altíssima reyna, es raçón no tener cólera conmigo, sino que V. A. se sirva aplacar al serenísimo Duque, mi señor, si alguna tiene contra di me [sic], pues al fin al fin soy su Gonçalico y su hijo y para conmigo, que soy tan del servicio de esa serenísima casa, no es menester tener cólera, sino mandarme líberamente y si no fuere obediente a sus mandamientos, quíteme la cabeça, que la vida, aunque fueran cien vidas, daré por bien empleada" (ASF, MP 5937, f. 51).
Es mucho más complejo el estatus de personaje histórico de Dios, ya sea dramatizado o mencionado. Dios no es en sí mismo un personaje histórico porque, a diferencia del hombre, no vive en el tiempo, sino en la eternidad. Por tanto, sería un error considerar su mera mención como una alusión histórica. Sin embargo, algunas de sus acciones se producen dentro del tiempo y modifican la Historia; y de ello hay innumerables muestras ya en el Antiguo Testamento. Además, la culminación de la intervención de Dios en la Historia es su propio nacimiento como hombre. La vida de Jesús sí es histórica y, por consiguiente, cualquier dramatización o alusión a ella no debe dejar de estudiarse. Precisamente, no cabe duda de que la Sabiduría en la loa de Llamados y escogidos ${ }^{20}$ y el Peregrino de la loa de El indulto general representan a Jesucristo. Es lógico que sólo la segunda persona de la Santísima Trinidad, Dios y hombre al mismo tiempo, figure como personaje en un tipo de obra dramática que se caracteriza precisamente por articular esas dos naturalezas del mundo, y siempre bajo una máscara que acentúe aún más esa ambigüedad. En resumen, apenas hay dramatización de la historia sagrada en las loas sacramentales de Calderón, ni en las dramatis personae ni en los argumentos, pero, frente a un posible exceso de abstracción, Calderón procura dejar pequeñas pistas de la historicidad de lo alegorizado.

Ciertamente, si se traslada a las loas sacramentales la clasificación de Arellano de los tres usos principales de la Biblia en los autos de Calderón, esto es, "menciones y adaptaciones de microtextos bíblicos", "macrotextos bíblicos parciales" y "macrotextos bíblicos argumentales"21, sólo los dos primeros -mucho más el primero que el segundo - están representados en las loas, mientras que en ningún caso el argumento está tomado de la historia sagrada. A diferencia del auto, la loa no utiliza la Biblia como materia historial, seguramente porque, en muy breve espacio

20 “La sabiduría, que según el sentido bíblico es un atributo de Dios, según la simbología sacramental representa la misma divinidad" (E. Rull, "Apuntes para un estudio sobre la función teológicopolítica...", p. 35)

${ }^{21}$ Vid. I. Arellano, Estructuras dramáticas y alegóricas..., pp. 64-95.

LECTURA Y SIGNO, 4 (2009), pp. 35-59 


\author{
CARIDAD Pues vaya a la Latina \\ no tanto porque haya sido \\ hospital de sacerdotes, \\ cuanto porque traducido \\ de la hebrea a la latina \\ cobre luz, vista y sentido. \\ MÚSICA Ya está Pablo a la vida restituido \\ y aunque ha visto no sabe decir
} [qué ha visto. ${ }^{17}$

Inscrito en la lectura de los memoriales que los necesitados madrileños han depositado en la Hermandad del Refugio (sobre cuyo sentido alegórico volveremos después)18, este pasaje presenta a un San Pablo legendario - caído del caballo, como marca la tradición - y se centra en el momento de su conversión, para dibujarlo como uno de los innumerables beneficiarios de la historia de la Salvación. En este caso, no interesan sus escritos, sino su vida; pese a que la intención de ilustrar la doctrina cristiana más relacionada con la Eucaristía se repite.

Aparte de San Pablo, que es el único que con toda propiedad se puede clasificar así, sería posible considerar también personaje de historia sagrada con texto al Demonio. Éste, que aparece en la loa de El indulto general, presenta en todo el teatro barroco dos caras simultáneas, la histórica y la alegórica, ya se halle en piezas sacramentales, ya en otros géneros; por ejemplo, como ha estudiado Ingrid Simson, en comedias de temática americana:

“[...] para el público de aquel entonces se distinguió de las personificaciones de nociones puramente abstractas. Aunque Satanás para los espectadores [...] fue en primer lugar una figura histórica, como incorporación del mal a este mundo, también es considerado como personificación alegórica"19.

${ }^{17}$ P. Calderón de la Barca, Loa en metáfora de la piadosa Hermandad del Refugio, ed. I. Arellano et alii, Pamplona / Kassel, Universidad de Navarra / Reichenberger, 1998, pp. 50-51. Todas las citas de la loa de La Hermandad del Refugio remiten a esta edición.

${ }_{18}$ Como ha observado Arellano, gran parte de esta loa responde al paradigma compositivo de la consulta de memoriales; vid. I. Arellano, Estructuras dramáticas y alegóricas..., pp. 53-54.

19 I. Simson, "La función de la alegoría en las comedias de temática americana en el Siglo de Oro", en C. Strosetzki (ed.), Teatro español del Siglo de Oro. Teoría y práctica, Frankfurt am Main / Madrid, Vervuert / Iberoamericana, 1998, p. 306. el medio idóneo para establecer lazos nuevos o abrirse puertas con cierta facilidad y al igual que hiciera desde Roma para buscar un acceso a Giacomo Boncompagno y a Luigi d'Este, ahora que necesita acercarse a la reina de Francia, envía un memorial a la Gran Duquesa (no a su esposo) y le pide que sea ella quien le dé acceso hasta Luisa de Lorena, la esposa de Enrique III. Estas gestiones estaban indicadas desde la corte española y a pesar de no conocer su contenido exacto, se podrían enmarcar dentro de los sucesos en torno a la firma en Joinville, ese mismo año, de un tratado secreto entre España y los príncipes católicos de la Casa de Lorena para apoyar un heredero católico al trono.

\section{Sereníssima señora,}

Yo me hallo muy triste de que no tengo cartas de V.A., sabiendo lo que yo la amo y la quiero, y siempre suspiro por bos. Y tengo raçón de suspirar, pues no nació muger de tanta discreción ny balor como tenéis la fama por todo el mundo. Pugliera ${ }^{58}$ Dios que yo pudiera yr dentro en esta carta para ber ese rostro angelical, porque no á cosa en el mundo que sea bastante para quitarme la malancolía y malos umores que tengo, sino solo veros. Y dichoso fue el Gran Duque en saver tan bien escoger y enplearse. La marquesa del Balle os escrive una carta, y es berdadera amiga vuestra, porque en occasiones que tocan a vuestro servicio se á señalado ${ }^{59}$. Yo me boy para Balencia, porque ya estoy mejor - bendito sea Dios - y para hacer diligencia para qu'el Rey me enbíe por allá, que lo deseo mucho por vuestro contento.

Mi heredero le é tenido muy malo y mi muger os desea conocer. Ya sabéis que yo soy muy amigo de mi honra y ansí, aunque baya a Ytalia, no pienso llebarla comigo, por los peligros que corren por allá. Si $\mathrm{V}$. A. no me manda otra cossa, aora quiero suplicaros un negocio que hagáis por mí, por ser cossa que dicen que me darán quince ducados y sé que lo podéis hacer con escrevir una carta a la reyna de Francia. Y también quiero que se lo pidáis al Gran Duque que scriva a su embajador, para que hable en este particular a la reyna. Y el memorial yrá dentro en esta carta de V. A., por donde se entenderá el negocio que pido.

Y no os olvidéis de mí y de que soy buestros amores a lo divino, con licencia del gran duque, porque aora no me puede ofender con el puñal, porque'stoy lejos. Y porque os riáys, daréys mis vesamanos aquella criada que se llama Catalina Velena, quando en Pisa me dio con la almohadilla de los alfileles [sic] y la aporee [sic], y V.A. me tenía miedo aquella noche. Y porque me hallo cansado y con gana de comer un par de perdices, que mi muger me mata que acave y me pide celos de los amores que escrivo a V. A., no digo

\footnotetext{
${ }^{58}$ Lee publiera.

${ }^{59}$ Lee sellalado.
} 
más, sino que Nuestro Señor guarde a V. A. muchos años y en estado acreciente como yo deseo. De Madrid y diciembre a 14 de 85.

Vuestro berdadero amigo para lo que me mandaredes,

Gonçalo de Liaño $0^{60}$

Al bufón no se le permite flaquear, solo el cometido de alegrar a su amo justifica una existencia en la que sus penas deben ceder ante la función. Por eso, aunque se encuentra muy mal, con una enfermedad que arrastra largo tiempo ${ }^{61}$, sus cartas a Bianca Capello no pasan de mencionarlo, si acaso lo hacen.

Es tanto el contento que tengo con la carta de vuestra alteza en quererme honrar en este christianismo Como el Prínçipe de Mantua enbió a convidar el baptismo de su hijo a Rey nuestro señor y al rey de Françia y al Emperador, tanbién yo inbié a convidar por el mismo orden, por venir mi hijo de gran linaje como yo vengo: su Magestad es mi compadre y la Enperatriz mi madrina. Mande vuestra alteza se hagan luminarias y fiestas por el infante que me ha nacido, que naçió día de Nuestra Señora a las diez ${ }^{62}$. Y cierto que pareçe tan goloso como yo, porque tomó unos lamedores ${ }^{63}$ muy bien, meneando los ojos como cosa que le dava mucho gusto. Reçibo a V. alteza por mi comadre y mi muger me manda que escriba a vuestra alteza que le vesa las manos por la honra que $\mathrm{V}$. alteza le haçe en quererla V. alteza honrar.

Y el negocio que V. alteza me encomendó sobre la Marquesa del Valle no le tengo olbidado, que ya he hablado a su Magestad y le di un memorial hecho de mi cabeza, y le hablé solo y dije marabillas del valor de V. alteza. Su Magestad me dijo que respondería al memorial y que acudiese a don Juan Idiáquez, que es con quien hemos de tratar estas cosas. Tengo esperança en Dios seré yo el enbajador destos negocios. Aý enbío a V. altez la copia del memorial que di a su Magestad, supplico a V. alteza que le vea y no dé relación a nadie hasta que se haga, que las cosas de veras tanbién las sé yo callar. Remítome a una carta que yo escribo a Luis de Ovara.

De los salchichones y quesos más o menos, parézeme que V. alteza se ha olbidado cómo me lo prometio en una carta los días pasados, y mi muger me da la me sa la vaya [?]

${ }^{60}$ ASF, MP 5938, f. 231 r. Entre f. 231v. y f. 232r. hay un recorte, en letra distinta de la carta, donde se ee una única línea: "El dixe a V. alteza se queda, porque el majadero del dueño no acudido".

Arandica, en carta de 28 de junio de 1586 desde El Escorial (ASF, MP 781, f. 603) dice: "mi amigo Gonzalillo á estado muy al cabo y está todavía muy malo. Su Magestad á mandado a dos dotore miren por él y se le tenga cuenta de todo aquello que fuere de menester. Es hombre que no es desagradezido y tienen vuestras altezas serenísimas aquí un buen solizitador en él, porque todo aquello que es en servizio desa casa lo aze como muy hombre de bien".

2 Todo este párrafo es sin duda burlesco, lo mismo que en otras cartas bufonescas donde el loco afirma su alto linaje para provocar la risa de su itnerlocutor, por eso no es posible aceptar la afirmación de S. Salort y S. Kubersky-Piredda, art. cit., 2006, p. 660, basándose en esta cita de que Liaño procedía de una familia noble.

${ }^{63}$ Lamedores: medicamento que se toma lamiéndolo.

\author{
PABLO. - [...] dáme \\ (Arrodillase a la Sabiduría.) \\ licencia, señora, puesto \\ a tus plantas te la pido \\ para ya que llegue a tiempo \\ que las armas en la mano \\ jugarlas pueda el ingenio \\ en loa tuya, pues es \\ tu loa su vencimiento \\ [...]. \\ (Loa de Llamados y escogidos, p. 452.)
}

Evidentemente, el mismo papel de defensor de la Sabiduría mediante argumentos extraídos de la Biblia y de obras teológicas lo realizan personajes no históricos en otras loas. Sin embargo, es significativa la elección de San Pablo por la autoridad que ha de tener su testimonio ante los espectadores ${ }^{16}$. Es el mismo crédito que se le atribuye cuando, en aras de explicar el sacramento de la Eucaristía, se le cita en las loas de El divino Orfeo (p. 1836) y de El verdadero Dios Pan (p. 1237). Sólo en la loa de La Hermandad del Refugio será distinta la función que cumpla la mención de San Pablo:

\begin{tabular}{|c|c|}
\hline FEE & $\begin{array}{l}\text { Un bizarro caballero, } \\
\text { precipitado y altivo, } \\
\text { cayó de un caballo y fue } \\
\text { tan grande su precipicio } \\
\text { que quedó ciego. Por él } \\
\text { yo, señora, te suplico. }\end{array}$ \\
\hline CARIDAD & ¿Tú, Fee? \\
\hline FEE & $\begin{array}{r}\text { Sí, porque su vida } \\
\text { me ha de ser de gran servicio }\end{array}$ \\
\hline CARIDAD & ¿Dónde fue? \\
\hline FEE & $\begin{array}{l}\text { En la Corredera } \\
\text { de San Pablo. }\end{array}$ \\
\hline CARIDAD & $\begin{array}{l}\text { Ya adivino } \\
\text { sus señas: ¿no es en la hebrea } \\
\text { lengua el más docto rabino? }\end{array}$ \\
\hline FEE & Sí es. \\
\hline
\end{tabular}

${ }^{16}$ Además, nadie podía cumplir mejor el papel de maestro de armas, pues el montante con que separa os combates y corta las disputas es el mismo que le acompaña en la iconografía posterior al Concilio de Trento. Vid. J. Carmona Muela, Iconografía de los santos, Madrid, Istmo, 2003, pp. 351-352.

LECTURA Y SIGNO, 4 (2009), pp. 35-59 
de la Iglesia - y de las que nos interesa la función que puedan cumplir dentro de la obra de Calderón, pero no el origen exacto ${ }^{13}$.

La preeminencia de la historia sagrada en las loas sacramentales se ratifica en el hecho de que el único personaje histórico dramatizado en las piezas inspeccionadas pertenezca justamente a esa categoría. Se trata de San Pablo, protagonista de la loa de Llamados y escogidos ${ }^{14}$, quien, en el plano historial, es el maestro de armas en un torneo de esgrima entre las cuatro partes del mundo ${ }^{15}$. El combate alegórico atañe a la Eucaristía, pues, siendo llamadas al Banquete, las partes del mundo - incluso Europa - dudan y se enzarzan en una discusión. Gracias a Pablo, que pone orden en el enfrentamiento deportivo y dialéctico, Europa vuelve a creer, vence en el torneo, ocupa el mejor asiento en el convite, al que acude el resto de personajes excepto la Apostasía, y ofrece un auto a la Sabiduría. En realidad, ni el desarrollo de la loa ni su feliz desenlace serían posibles sin el continuo recuerdo de la Palabra de Dios por parte del apóstol, que incluso recurre a sus propios escritos:

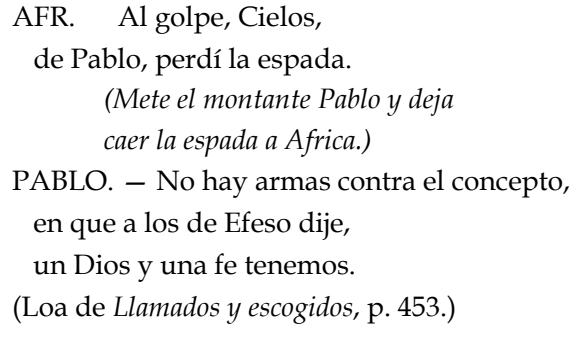

Es más, sin el personaje de Pablo, ni siquiera existiría la propia loa, nacida como ofrenda suya a la Sabiduría:

13 “La presencia de la Biblia en los autos sacramentales calderonianos es vastísima, y exigiría un libro entero muy documentado y detallado, en el que un estudioso igualmente versado en la Biblia y en la obra calderoniana examinara los distintos modos de uso, adaptaciones y funcionalidades dramáticas doctrinales de los intertextos bíblicos, etc." (I. Arellano, Estructuras dramáticas y alegóricas..., p. 59). 14 "Llama la atención la frecuencia con la que se suele citar a San Pablo en este tipo de loas" (K. Spang, "Aproximación a la loa sacramental y palaciega: notas estructurales", en Apuntes sobre la loa sacramental y cortesana..., p. 17).

5 Esta loa se ajusta, así, al paradigma compositivo de los juegos de destreza. Vid. I. Arellano Estructuras dramáticas y alegóricas..., pp. 31-32.
Supplico a V. alteza que cumpla su palabra y porque deseo verme en camino para ir a V. alteza, plega a Dios se cumpla mi deseo. $Y$ acuérdese vuestra alteza de que se me pague toda la resta que se me deve y se dé a Baltasar Suárez. Y porque no tengo más que avisar, sino Dios me conserve en gracia de V. alteza y del Gran Duque, mi señor; y al Marquesito con la buena Peregrina. Fecha en Madrid oy 19 de agosto de 1586.

Vuestro Gonzalo que hos desea más ver que no escrebiros,

Gonçalo de Liaño $0^{64}$

A comienzos de 1587 escribió una carta desde Milán, pero en marzo está de vuelta en Madrid y pasará allí casi el resto del año. En julio le anuncia a la Gran Duquesa que ya está en perspectiva un viaje próximo y el rey le ha dado una joya de regalo, pero su viaje no será directo:

También me encarga su Magestad negoçios para Turín, adonde forçosamente havré de yr antes y entretenerme çerca de un mes, pero puede estar segura V.A. que me dare toda la priesa posible para gozar del Poggio y de la buena conversaçion que me han dicho que havrá allá. Y al tiempo que yo partiere, que será con mucha brevedadd, escriviré otra con algún particular de más

Efectivamente, cumple su promesa y en agosto le envía las últimas noticias antes de iniciar el viaje.

\section{Sereníssima señora}

Esta es para abisar a V.A. cómo el lunes me despedí de su Magestad en San Lorenço, que fue muy sentida la mi partida, y me dixo de palabra amorosas que dijese a $\mathrm{V}$. A. y presentase esta joia de parte suia; mas no puedo deçir nada hasta que me bea con $\mathrm{V}$. A. Mándame su Magestad que pase por Turín y que bea a la Infanta y le dé un despacho que me á dado, con un presente que yo llebo, y en acabando de haçer mi embajada abisaré a V. A. desde el camino donde yo estubiere. Y quando entrare en el estado del Gran Duque es menester que me embíe el maiordomo con todo el aderezo de comida, como suelen haçer a otros embajadores, y V. A. me á de resçibir como a embajador y darme silla y honrrarme, que yo daré a V. A. la mano derecha, que no lo hago con otros. Y enbía orden a Génoba que como me desenbarque, me bisiten de parte de V. A., y abisarme cómo me a de tratar, y si se me á de haçer el reçebimiento que tengo dicho; y haçer las amistade entre mí y el Gran Duque, y que como yo llegue allá yo daré satisfaçión de todas las cosas que me á encomendado.

Mi muger echa a V. A. maldiciones, que diçe que á sido la ocasión de partirme yo de aquî y siente mucho mi partida. El embajador diçe que dará 4 reales a mi muger cada día para

\footnotetext{
${ }^{64}$ ASF, M. P. , 5943, f. 4 r.-v.
}

LECTURA Y SIGNO, 4 (2009), pp. 9-33 
que coma mientras yo estubiere por allá, aunque á dicho que más ganaba yo por acá mi muger. Naçióme una hija a çinco de agosto y la enbío a criar a una aldea con otro hijo que tengo allá, pues me debéis tanto que más de quatro tienen enbidia de lo que yo echo [sic] por vos. Y esto lo diré yo quando esté por allá. Que mandéis, como esta carta llegare, escribir luego al embajador que está acá que se pague çinquenta reales más para pagar las amas, porque mi mujer esté con vos bien, que las maldiçiones las torne en bendiçiones. Yo entiendo que se enbiará alguna cosa a vuestro hijo el Marquesito de parte del Rey o del Prínçipe, que será alguna espada de precio, porque me lo á dicho un ministro prinçipal oy. Y porque yo me parto la semana que biene para Italia, no digo más. De Madrid y de agosto a 20 de 1587.

Vuestro berdadero amigo para lo que me mandaredes,

\section{Gonçalo de Liaño}

Esta fue la última carta de Gonzalo de Liaño que recibió la Gran Duquesa. El día 10 de octubre se difunde la noticia de que el Gran Duque está enfermo, luego también su esposa. El 19 de ese mes moría Francisco I y al día siguiente Bianca Capello. Pocos días antes habían hecho las paces con el cardenal Fernando de Medici, hermano y futuro Gran Duque, con quien habían estado desde el 25 de septiembre pasando unos días en la villa de Poggio Caggiano. Los rumores se extendieron diciendo que ambos o al menos ella, siempre una advenediza para su cuñado y bajo sospecha de haber engañado al Gran Duque haciendo pasar al "Marquesito" por hijo suyo, había sido envenenada ${ }^{66}$. En el archivo no hay cartas de Liaño durante unos meses, pero en mayo de 1588 Gonzalo escribe desde Mantua al nuevo Gran Duque, Fernando I, para apaciguar su ira por el retraso en la llegada informándole de algunas gestiones y de que está indispuesto. A la vez, siguiendo su costumbre, le pide a Leonora den Medici, duquesa de Mantua, que escriba por su parte una carta donde efectivamente ella confirma que dada la salud de Gonzalo no debe partir. Aun así el 5 de junio está en Venecia y desde allí Gonzalo vuelve a escribir al Gran Duque asegurando que se verán pronto. En el mes de septiembre de ese 1588, un tal fray Diego Pardo se dirige al Gran Duque diciendo:

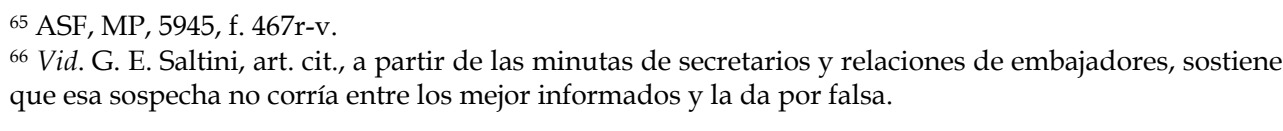

DÍA $1^{\circ}[\ldots]$ tú que sin tiempo al tiempo conociste siendo una masa obscura [...].

(Loa de El Año Santo de Roma, p. 17.)

Además de autorizar el estudio de la historia sagrada, el breve examen del tiempo en las loas sacramentales ha servido para acercarnos a la idea que Calderón tiene de la Historia desde el punto de vista filosófico. Sin duda, es una concepción teológica y lineal, pues la Providencia ha trazado un designio de progreso. El devenir de la historia humana, aparentemente arbitrario en otros géneros dramáticos, adquiere con el uso de la alegoría un sentido cristiano, y, aunque Dios sí exista fuera del tiempo, el hombre ha recorrido varios períodos históricos antes de ser redimido. Se trata de la concepción de la Historia que nació con San Agustín ${ }^{12}$, en la que tanto la oposición entre tiempo y eternidad como el concepto de Gracia son fundamentales.

\section{LA Historia SAGRADA}

La historia sagrada es la materia histórica propia de los géneros sacramentales. Por historia sagrada entendemos las narraciones históricas contenidas en la Biblia, pero en estas piezas - frente a lo que pueda ocurrir, por ejemplo, en los dramas - los santos reciben un trato muy similar, por lo que su examen será conjunto. Cabe advertir, por otro lado, que no es éste el lugar para señalar las fuentes bíblicas o patrísticas de los versos de los autos y loas sacramentales de Calderón, excepto en algún caso particular. Esa labor, además de haber sido realizada con gran acierto por algunos editores de los textos (en especial en la edición del GRISO de la Universidad de Navarra), superaría con creces el espacio de este trabajo, sin llegar a aportar información apreciable para sus conclusiones, porque se trata de fuentes muchas veces apenas modificadas - precisamente por la necesidad de mantener la doctrina

12 También Rull opina que la teoría calderoniana de las Tres Edades del Mundo "parece inspirada en San Agustín” (E. Rull, “Hacia la delimitación de una teoría político-teológica...", p. 760)

LECTURA Y SIGNO, 4 (2009), pp. 35-59 


$$
\begin{aligned}
& \text { las nuevas envió inferiores } \\
& \text { ministros, a cuyo fin } \\
& \text { les dió sus postas el tiempo } \\
& \text { y la fama su clarín. } \\
& \text { (Loa de La vacante general, pp. 471-472.) }
\end{aligned}
$$

En alguna de las loas no se resume la historia de la Salvación, pero se constata de igual modo la actualidad de la Ley de Gracia; por lo que también se presupone la existencia de un tiempo anterior a ésta y, en consecuencia, la realidad del tiempo como estado opuesto a la eternidad. Es el caso de la loa de Llamados y escogidos, en la que San Pablo advierte a Asia11 que "no ha de haber otra venida" (p. 454), o el de la loa de El viático cordero, donde se verifica que "a un sacrificio / Dios de oblación incruenta / todo lo ceremoniado / de la anciana ley abrevia" (p. 1155). En esta última pieza, por otro lado, las Horas, es decir, los husos horarios, se convierten en personajes, y un reloj forma parte de la escenografía, de modo que al tiempo histórico se añade un tiempo artificial, desmenuzado, que preocupaba especialmente al hombre barroco.

En realidad, siendo cierto todo lo dicho hasta aquí, esto es, que, en el plano historial, las loas sacramentales suelen tener lugar en un día de Corpus del siglo XVII y, en el alegórico, resumir la historia de la Redención, no dejarían de hallarse incongruencias si se analizaran las piezas perdiendo de vista su carácter sacramental. Como era presumible, son numerosos los anacronismos - así, la presencia de San Pablo como personaje de la loa de Llamados y escogidos - y otras licencias como, por ejemplo, el desorden cronológico que se observará en la historia sagrada alegorizada en La Hermandad del Refugio. Lo que nos interesaba aquí era únicamente comprobar la temporalidad de las loas sacramentales de Calderón y así se ha hecho. Sólo en unos versos, pertenecientes a la loa de El Año Santo de Roma, el Día Primero de la Creación le recuerda a la Naturaleza la inexistencia del tiempo hasta ese momento:

\footnotetext{
${ }^{11}$ En esta loa, Asia representa el Judaísmo, Europa el Cristianismo, África el Ateísmo y América la Idolatría; de manera que "se centra en Europa el mensaje de la Tercera Edad teológica" (E. Rull, "Apuntes para un estudio sobre la función teológico-política...", p. 34). En esta elección ve Rul motivos políticos.
}

Y porque podría ser aún no acordarse vuestra alteza de quien esta escribe, digo que soy aquel fraile de Sant Francisco, tío de la muger de Gonzalo Liaño, que esté en el zielo, de quien traía cartas para el marido para que él me faboreziera con vuestra Alteza y parézeme que murió antes que acá llegase ${ }^{67}$.

Ya fuera por su enfermedad o porque no estaban los tiempos para bromas, en estas últimas cartas no recurre al humor. Conocía al antiguo Cardenal y nuevo Gran Duque, había hecho gestiones para él ${ }^{68}$, pero basta con breves misivas de contacto e información con las que apaciguar su posible impaciencia y tenerle al tanto de sus movimientos. La posibilidad de usar la burla no la establecía el bufón, sino su amo, porque al fin y al cabo se trataba de un modo de comunicación que implicaba a ambas partes y en la que el poderoso marcaba las pautas. Gonzalo de Liaño, hombre de mundo, hábil negociador y gestor, entiende la risa como una forma de franquearse el paso al corazón de las personas, pero ésta solo es posible cuando encuentra un interlocutor dispuesto a participar de lo festivo, a compartirlo y alentarlo. En este aspecto Bianca Capello actuó como una cómplice necesaria que le permitió desplegar su talento en las cartas, a las que respondía probablemente con un tono similar69. Por ello, estas cartas fueron escritas por el bufón, pero no dejan de ser a la vez una muestra del espíritu de la Gran Duquesa, del ambiente de su corte y en parte obra suya al alentar esta escritura que hoy nos sigue divirtiendo y nos deja atisbar una perspectiva más viva y humana de la historia.
${ }^{67}$ ASF, MP, 800, f. 240

${ }^{68}$ Una carta de 7 de julio de 1582 (ASF, MP, 756, f. 63) que está entre las destinadas al Gran Duque, es mucho más probable que estuviera dirigida al Cardenal, porque trata al destinatario de "ilustrísima" y menciona al Gran Duque como un tercero. Esta carta tiene un tono jocoso y le pide permiso para salir de Florencia e ir a pescar

${ }^{9} 9$ Son muchas las veces en que Liaño menciona haber recibido cartas; en una de 3 de febrero de 1596 le dice: "dízeme su Magestad que si el Gran Duque entendiera lo que m'escrivís de amores en vuestra carta, que si yo estuviera allá, que corriera peligro", ASF, MP, 5938, f. 629-630.

LECTURA Y SIGNO, 4 (2009), pp. 9-33 
recorre durante la fiesta del Corpus las calles de Madrid, cuya topografía mística similar a la que encontraremos en La Hermandad del Refugio - permite alegorizar la

Redención:

$$
\begin{aligned}
& \text { FE. [ [...] } \\
& \text { Ese embozado galán } \\
& \text { del cristalino viril, } \\
& \text { sale de Santa María, } \\
& \text { [...]. } \\
& \text { A la calle nueva llega } \\
& \text { y nueva para salir } \\
& \text { a la gran Plaza del Mundo, } \\
& \text { en cuyo sitio advertir } \\
& \text { debes, que su principal } \\
& \text { fábrica, heroica y gentil, } \\
& \text { la Casa es del Pan, en cuyos } \\
& \text { umbrales contribuir } \\
& \text { verás sus frutas al año; } \\
& \text { no es ocasión de inferir } \\
& \text { que el agrio de la manzana } \\
& \text { se quita con Pan; [...]. } \\
& \text { Aquí a su piadoso oído } \\
& \text { llegó el clamar y el gemir } \\
& \text { de los presos de } l a \text { cárcel, } \\
& \text { [...]; y él } \\
& \text { compadecido de oír } \\
& \text { sus lamentos, prometió } \\
& \text { sus prisiones redimir. } \\
& \text { Con que pasó a Santa Cruz } \\
& \text { con deseo de cumplir } \\
& \text { su Palabra; [...]. } \\
& \text { En todo el orbe se oyó, } \\
& \text { desde el cénit al nadir } \\
& \text { su triunfo: El Correo Mayor } \\
& \text { lo diga, pues a esparcir }
\end{aligned}
$$

la comprensión de las loas. Vid. E. Rull, “El auto sacramental de Calderón como género. Un ejemplo: Psiquis y Cupido", en A. Egido (ed.), Lecciones calderonianas, Zaragoza, Ibercaja, 2001, p. 138; E. Rull, “Hacia la delimitación de una teoría político-teológica en el teatro de Calderón”, en L. García Lorenzo (ed.), Calderón. Actas del «Congreso Internacional sobre Calderón y el Teatro Español del Siglo de Oro». (Madrid, 8-13 de junio de 1981), Madrid, C.S.I.C., 1983, t. II, pp. 759-767; y E. Rull, "Apuntes para un estudio sobre la función teológico-política de la «loa» en el Siglo de Oro", en I. Arellano et alii (eds.) Apuntes sobre la loa sacramental y cortesana. Loas completas de Bances Candamo. Estudios y ediciones críticas, Kassel, Reichenberger, 1994, pp. 25-35. 
respectivamente, de Felipe IV y de Carlos II no deja lugar a dudas. Sólo una de las ocho loas analizadas aquî́, en concreto la de El indulto general, no es contemporánea en el plano historial, sino que, atravesando ya el umbral alegórico, sitúa el argumento en el período histórico de la Ley Natural y aplaza hasta el auto la instauración de la Ley de Gracia:

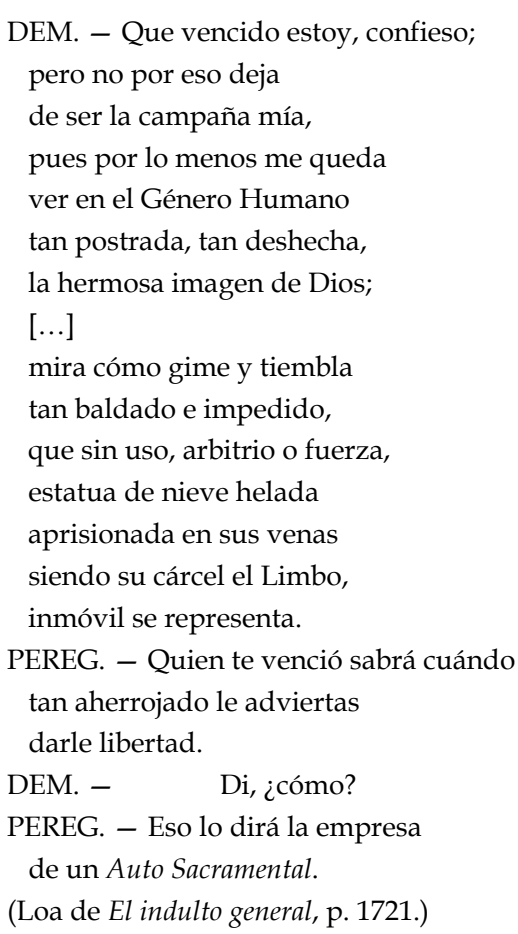

En efecto, el plano alegórico de las loas sacramentales de Calderón no sólo no es tampoco atemporal sino que tiene la virtud de condensar - de forma más o menos cronológica - la historia teológica de la Humanidad, es decir, la historia de la Redención, que culmina con la Ley de Gracia que instituye Jesucristo a través de la Eucaristía, tras las dos edades anteriores en las que reinan respectivamente la Ley Natural y la Ley Escrita ${ }^{10}$. En la loa de La vacante general, por ejemplo, el Santísimo

Se trata de las loas de Llamados y escogidos, La vacante general, El Año Santo de Roma, La Hermandad del Refugio, El divino Orfeo (segunda versión), El viático cordero, El verdadero Dios Pan y El indulto general. ${ }^{10}$ Este alcance alegórico del argumento es asimismo el más frecuente en el auto sacramental calderoniano y, por tanto, los estudios de Rull al respecto son también de todo punto necesarios para

\section{HISTORIA SAGRADA Y LOA SACRAMENTAL EN CALDERÓN*}

\section{VANESSA FORTUÑO GÓMEZ}

Universitat de Barcelona

\section{TIEMPO E Historia EN LAS LOAS SACRAMENTALES}

Estudiar el uso de la historia sagrada en las loas sacramentales de Calderón implica plantearse el problema del tiempo en todas las piezas sacramentales, ya que, la ausencia de tiempo en la obra dramática, y por tanto de cronología, impediría hablar de Historia, pues no es propiamente histórico aquello que se halla sub specie aeternitatis. Como mucho, se podría hacer referencia a personajes que el espectador sabe históricos o a parcelas temporales que se han convertido en simultáneas y han

\footnotetext{
"Recibido: 11-03-2009 Aceptado: 12-05-2009
} 
perdido su sentido histórico. $\mathrm{Y}$ así sería, en efecto, de continuar vigentes las teorías que, durante décadas, habían considerado atemporal el auto sacramental'; ninguna voz se alzaba en contra de esa definición, que había pasado ya a las historias del teatro español². Sin embargo, Arellano ha esclarecido la cuestión:

Calderón no anula el tiempo y espacio en sus alegorías, ni prescinde de ellos; prescinde de ciertas constricciones de su manipulación. La libertad omnímoda que le conceden las doctrinas poéticas de la época y sobre todo el peculiar mecanismo alegórico, le permiten por el contrario, una potenciación compleja de estos aspectos, una presencia no nula, sino más bien proteica, en la que los tiempos y los espacios dramáticos se multiplican en facetas extraordinarias, se transmutan, se funden o interrelacionan en todas las maneras posibles $[\ldots]]^{3}$

El plano historial del auto no pierde nunca la temporalidad. Es sólo en el plano alegórico donde el dramaturgo se permite dar un nuevo sentido a ese tiempo, o, incluso, ofrecer un atisbo de eternidad:

Espacio y tiempo se transmutan, alcanzan otras dimensiones espirituales, pasan al plano del significado alegórico, pero no anulan su significado historial. Los personajes de diferentes épocas y mundos se reúnen en la proyección alegórica, o prefiguran otros posteriores, componentes todos de un proceso diseñado por Dios, en quien todo es presente. ${ }^{4}$

Estas reflexiones son en cierto modo válidas para las loas sacramentales; $y$, de hecho, Arellano incluye entre sus ejemplos la Loa en metáfora de la piadosa Hermandad del Refugio. En concreto, en las loas sacramentales de Calderón, el plano historial se sitúa en una fecha determinada, justamente el día en que tiene lugar la representación. Para empezar, en casi todas las piezas los propios personajes anuncian que es el día de Corpus Christi:

${ }_{1}^{1}$ Acerca de esta tradición crítica, vid. I. Arellano y J. E. Duarte, El auto sacramental, Madrid, Laberinto, 2003, p. 48

2 Por ejemplo, Ruiz Ramón resume así las ideas en curso: “[...] la transposición alegórica del mundo sacramental conlleva, como reflejo obligado, la atemporalización propia del auto sacramental, cuya «historia» dramática transcurre fuera de todo tiempo histórico", / (F. Ruiz Ramón, Historia del teatro español (Desde sus orígenes hasta 1900), Madrid, Cátedra, 1996 ( $\left.9^{\mathrm{a}} \mathrm{ed}.\right)$, p. 273).

3 I. Arellano, Estructuras dramáticas y alegóricas en los autos de Calderón, Pamplona / Kassel, Universidad de Navarra / Reichenberger, 2001, p. 118

${ }^{4}$ Ibid., pp. 121-122.

\section{APOST. - ¿Qué celebráis este día? \\ FE. - Aquel Misterio feliz, \\ en que merecen mis fieles \\ en Pan ver su Dios por mí. 5}

Además, se añade, por lo general, información suficiente para ubicar la acción no sólo en un día de Corpus indeterminado, sino del mismo año del siglo XVII que están viviendo los espectadores. El texto de la loa de El Año Santo de Roma llega incluso a encerrar en él la fecha de su representación:

\section{$[\ldots]$ \\ dando el año de cincuenta \\ alegórico motivo \\ a que su título sea \\ El Año Santo de Roma.}

En ocasiones, la condición de "drama contemporáneo" se sugiere en la loa sacramental a partir de las alusiones históricas y geográficas. En la loa de Llamados y escogidos, al igual que en la Europa del siglo XVII, la Apostasía reina en las provincias del Norte ${ }^{7}$. Por otro lado, es harto evidente que el argumento de la loa de La vacante general se desarrolla en 1648, año del restablecimiento de las representaciones:

$$
\begin{aligned}
& \text { [...] el día que manda } \\
& \text { sus fiestas restituir } \\
& \text { católica majestad, } \\
& \text { [...]. } \\
& \text { (Loa de La vacante general, p. } 472 . \text { ) }
\end{aligned}
$$

También la acción de la loa de La Hermandad del Refugio sucede en el Madrid del siglo XVII. Y en las loas de El viático cordero y El verdadero Dios Pan, la mención,

5 P. Calderón de la Barca, "Loa para el auto sacramental intitulado La vacante general", en Obras completas. Tomo III: Autos sacramentales, ed. Á. Valbuena Prat, Madrid, Aguilar, 1952, p. 470. Todas las citas de la loa se tomarán de esta edición, así como las de las loas de Llamados y escogidos, El divin Orfeo, El viatico cordero, El verdadero Dios Pan y El indulto general.

A partir de aquí, el texto de la loa de El Año Santo de Roma se citará siempre por la edición de I. Arellano, "Para el repertorio de loas sacramentales calderonianas. Un autógrafo inédito de Calderón: la loa auténtica de El Año Santo de Roma", Criticón, 62 (1994), pp. 7-32. Este primer fragmento se halla en la p. 22.

Vid. Loa de Llamados y escogidos, p. 454.

${ }^{8}$ Vid. E. Cotarelo y Mori, Ensayo sobre la vida y obras de D. Pedro Calderón de la Barca, Madrid / Frankfurt am Main, Iberoamericana / Vervuert, 2001, p. 267

LECTURA Y SIGNO, 4 (2009), pp. 35-59 
Segundo testamento de Doña Antonia Cáncer

Archivo de Protocolos de Madrid, tomo 13087, fols. 25r-27v.

“En el nombre de Dios Todopoderoso y de la Virgen María Santísima, su Madre. Amén.

Sepan cuantos esta pública escritura de testamento, última y postrimera voluntad, como yo doña María de Cáncer, vecina de esta villa, hija legítima y de legítimo matrimonio de don Jerónimo de Cáncer, natural del Reino de Aragón y vecino que fue de esta villa, y de doña María Ormaza, natural de esta Corte, difuntos, estando enferma en la cama de la enfermedad que Dios Nuestro Señor ha sido servido de me dar y en mi juicio y entendimiento natural, creyendo como firmemente creo en el Misterio de la Santísima Trinidad: Padre, Hijo y Espíritu Santo, tres personas distintas y una esencia divina, y en todo lo demás que tiene, cree y confiesa la Santa Madre Iglesia Romana, debajo de cuya fe y creencia, protesto vivir y morir, como católica cristiana ${ }^{12}$, temiéndome la muerte, cosa natural y cierta a toda criatura viviente y deseando, cuando este caso llegue tener dispuestas mis cosas, como mejor convenga al servicio de Dios nuestro Señor, tomando por mi intercesora y abogada la Virgen María, Madre de Dios y señora nuestra, concebida en gracia y al ángel bendito de la guarda, santos de mi devoción y demás de la corte celestial, para que intercedan con su divina majestad guíe mi alma a gozar de su excelentísimo reino.

\section{[fol. $25 \mathrm{v}$ ] Hago y ordeno mi testamento en la forma y manera siguiente:}

Lo primero encomiendo mi alma a Dios Nuestro, y que la Cruz y redimió con su preciosa sangre y el cuerpo a la tierra, de que fue formado, el cual es mi voluntad vaya adornado con el hábito de nuestro seráfico padre san Francisco, de cuya tercera orden soy hermana; a quien pido y encargo respeto de hallarme pobre sin medios

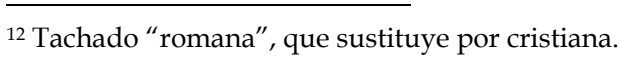

que era caos el Universo,

sin advertir que había dicho

la Sacra Historia primero

que no era nada.

(Loa de El verdadero Dios Pan, p. 1238.)

Pero las mismas alusiones, estudiadas desde el punto de vista del espectador, aún cumplen una última función: catequística. Si bien la función didáctica o pedagógica de los autos sacramentales y de la fiesta sacramental en su conjunto ha sido cuestionada en algún estudio ${ }^{28}$, es casi unánime, y suficientemente demostrada, la opinión de que el adoctrinamiento es una de las principales finalidades de este tipo de teatro ${ }^{29}$. El examen por separado de la loa sacramental como género ha llevado a la misma conclusión: “En la finalidad la loa sacramental discrepa de las demás, dado que [...] hallamos una intención didáctica muy precisa y es la de acercar al público el misterio de la Eucaristía" 30 . Y un detallado estudio de C. Erdocia sobre las loas sacramentales de Calderón ha terminado de fijar la misma finalidad en esas piezas concretas ${ }^{31}$. El análisis de la utilización de la Biblia en estas obras nos proporciona ahora la oportunidad de detectar que es precisamente la mención de elementos de historia sagrada la principal responsable del cumplimiento de la intención catequística de los textos. Algo que, en algún caso como el de la loa de $\mathrm{La}$

28 " Al pueblo español no había que instruirle desde el teatro, pues estaba ya suficientemente instruido desde los púlpitos, las misas, las procesiones, las conmemoraciones cíclicas cristianas y los actos más cotidianos de su vida, fuese seglar o eclesiástica" (E. Rull (ed.), Autos sacramentales del Siglo de Oro, Barcelona, Plaza \& Janés, 1986, p. 21).

Vid. A. A. Parker, Los autos sacramentales de Calderón de la Barca, Barcelona, Ariel, 1983, p. 53; K Spang, "El auto sacramental como género literario", en I. Arellano et alii (eds.), Divinas y humana letras. Doctrina y poesía en los autos sacramentales de Calderón. Actas del Congreso Internacional, Pamplona Universidad de Navarra, 26 febrero-1 marzo, 1997, Pamplona / Kassel, Universidad de Navarra / Reichenberger, 1997, pp. 504-505; F. B. Pedraza Jiménez, Calderón. Vida y teatro, Madrid, Alianza, 2000, p. 257; E. Rodríguez Cuadros, Calderón, Madrid, Síntesis, 2002, p. 121. Muy ligada a la didáctica, se halla la función litúrgica, la cual, sin embargo, no influye en el texto teatral de forma tan clara, sino que es justamente lo que convierte al auto en algo más que un género dramático; vid.. J. M. Díez Borque, Teoría, forma y función del teatro español de los Siglos de Oro, Palma de Mallorca, José J. de Olañeta, 1996, pp. 136-140.

${ }^{3}$ K. Spang, "Aproximación a la loa...", pp. 17-18

${ }^{1}$ Vid. C. Erdocia Castillejo, Hacia una poética de la representación sacramental del Siglo de Oro español: las loas sacramentales de Calderón de la Barca y la celebración del Corpus Christi, Princeton University, 199 [tesis doctoral], p. 91.

LECTURA Y SIGNO, 4 (2009), pp. 35-59 
vacante general, Enrique Rull esbozó hace tiempo, aunque prestando excesiva atención aún al pueblo como receptor del mensaje: “Calderón está explicando, enseñando, adoctrinando, convenciendo al pueblo con argumentos, imágenes, testimonios de todo orden [...]. Lo importante es cómo las imágenes de los propios textos bíblicos acuden a su mente para ilustrar sus propios argumentos" 32

El número tan elevado de citas bíblicas con fines catequísticos sólo adquiere sentido si se tiene en cuenta que, según ha demostrado Tietz, el "espectador implícito" de las piezas sacramentales no es el vulgo, sino la elite social y cultural de la Corte $^{33}$. No es que el vulgo no fuese también adoctrinado a través de otros elementos dramáticos e incluso mediante conceptos teológicos ineludibles en la formación de todo católico, pero las múltiples dificultades de cada alusión van dirigidas sólo a una parte del público, o, mejor dicho, a varios de los públicos - salvo el vulgo- que presenciaban los autos durante los días en que éstos eran representados ${ }^{34}$. Con esta excepción, no hay mejor manera de catequizar al espectador de la loa y del auto sacramentales, porque la Historia es ahí un excelente instrumento didáctico a causa de la escasa distancia que hay entre la exposición de la historia sagrada - y más para argumentar verdades de fe - y lo que se conoce como catequesis.

La única función desvinculada de la catequesis que cumplen las "menciones y adaptaciones de microtextos bíblicos" en las loas sacramentales calderonianas es la

32 E. Rull, "Instrucción y concelebración populares en el auto sacramental”, en J. Álvarez Barrientos y A. Cea Gutiérrez (eds.), Actas de las Jornadas sobre teatro popular en España, Madrid, C.S.I.C., 1987, p. 57 3 Vid. M. Tietz, "El «espectador implícito» de los autos sacramentales de Pedro Calderón de la Barca" en La dramaturgia de Calderón..., pp. 561-586,

${ }^{4}$ Como expone, entre otros, Díez Borque, si se obvian las modificaciones que pudiese haber de un año a otro, el orden de la representación de los autos en la fiesta del Corpus era el siguiente: el jueves por la tarde se representaban ante los reyes y, a continuación, ante los miembros del Consejo de Estado y del Consejo de Aragón. El viernes por la mañana los distintos públicos estaban formados por el Consejo de la Inquisición, el Consejo de Cruzada y el Consejo de Hacienda. El viernes por la tarde lo espectadores eran la Villa de Madrid, el Consejo de Indias y el Consejo de Órdenes. El sábado era e urno, sucesivamente, del presidente del Consejo de Castilla, del pueblo y del Consejo de Italia. Vid. J. M. Díez Borque, Los espectáculos del teatro y de la fiesta en el Siglo de Oro, Madrid, Laberinto, 2002, p. 234. [197v] Cuatro toallas que tengo, tres con puntas y bordadas, y otros manteles de altar, todo lo mando para después de mis días a la sacristía de esta casa, y quisiera tener mucho que dejarlas de grande amor que tengo a la casa.

A las mandas forzosas mando dos tercios con que lo que aporten de mis bienes, y para cumplir y pagar este testamento y lo contenido dejo y nombro por mis testamentarias a las madres priora, suprioras y consultoras que son $-\mathrm{y}$ por ninguno fuera de este convento, a las cuales suplico lo acepten y se encarguen de sobrevisar la cobranza de mi renta, si me quedase debiendo después de mis dichos y del que me mando mi madre; nombrando para llevarla - por si fuese - para jueces y le doy poder para todas las causas a la testamentaria en toda ampliación y generalidad y que si es necesario dar litigio, aunque sea y osa darle año del que haya a cargo. $Y$ en el tiempo que quedare dejo y nombro por mi heredera a mi alma para que se convierta en hacer bien por ella.

Y por esto revoco y anulo, y doy por ningunos y de ningún valor ni efecto, todos y cualesquiera testamentos que haya hecho por escrito y de palabra y poderes que para ello haya nombrado, que quiero que no valgan ni háganse en fuero ni fuera de este alguno, este que al presente tengo, y otorgo que quiero que vaya por mi testamento a mi última y postrera voluntad y en aquella vía y forma que más haya lugar de servicio, yo en testimonio lo otorgo en si. Están presentes como testigos en este convento de Santa Isabel la Real de Madrid, a veintisiete días del mes de agosto de mil y seiscientos sesenta y un años, siendo testigos Bartolomé Martínez Marín, Juan de Velasco, Sebastián Ortiz, Pedro de Finosares.

Estando presente la dicha otorgante que yo leí la misma y se conserva, lo firmo=lo que guardare

Doña Antonia Cáncer

Firmas ilegibles 
Yten es mi voluntad que de lo que me quedare debiendo de la dicha pensión y renta del Consejo de Indias, después de mis días se me digan en este convento tres misas cantadas con sus vigilias, y por ello se den de limosna cien reales por pagado cada una, y si las madres - a quien lo pido - no quisiesen acceder a que se digan en este convento, las doy facultad para que las hagan decir en la parte que les pareciere, y que sepan que dichos trescientos reales, de lo que así se cobrara de lo que me quedare debiendo de la dicha renta.

Dos cuadros que tengo, uno de Nuestra Señora del Pópulo y otro del Buen Pastor, es mi voluntad que el que cobren las madres de los dos se les de y el otro segundo en el cuarto de las seglares.

Los bienes que dejo, se han de vender para hacer bien por mi alma, son: Una cama de nogal con su colgadura y cobertor, una colcha, dos colchones, fracadas ${ }^{11}$, sábanas, almohadas y camisas y un cofre y lo demás que pareciese ser mío al tiempo de mi muerte, dejando lo que llevo mandado.

Yten tengo un bufete de nogal con tres cajones, aldabas y cerraduras doradas, con algunas flores y ramilletes; es mi voluntad que cuando fallezca se conserve para el servicio de una imagen pequeña de piedra de Nuestra Señora, mas tengo una salvilla pequeña de plata que costará cinco o seis reales de a ocho, la coloquen con flores y hará el servicio para la imagen pequeña.

Tres varas de puntos de Flandes que tengo sin mojar a la sacristía de esta casa.

Una lámina que tengo - que es imagen de la creación - de suelta, mando a las madres para que la tengan en la casa.

${ }^{11}$ Fraçada: Manta tejida de lana y peluda que se echa sobre la cama, que por tener el pelo largo y revuelto, se dijo así. Vid. S. de Covarrubias Orozco, Tesoro de la Lengua Castellana o Española, Madrid, Castalia, 1995, p. 607. comparativa, en lo que representa un uso estilístico y, por lo general, caracterizador de personajes. Una muestra de esta lógica preferencia del dramaturgo por los nombres bíblicos a la hora de establecer símiles en el texto de dichas piezas es la siguiente referencia a 1 Samuel 17, 38-39:

$$
\begin{aligned}
& \text { AF. } 4 .{ }^{\circ}-\text { Armado el pecho de Ira, } \\
& \text { ¿quién habrá que a mí se atreva? } \\
& \text { DEM. - Quien vea que aquestas armas } \\
& \text { son las que te desalientan. } \\
& \text { AF. } 4 .{ }^{\circ}-\text { ¡Ay de mí! El grabado acero } \\
& \text { que sobre mis hombros pesa, } \\
& \text { bien como a David me aflige } \\
& \text { para que lidiar no pueda. } \\
& \text { (Loa de } E \text { lindulto general, } \text { p. } 1719 .)
\end{aligned}
$$

Pasando ya al plano alegórico de la loa sacramental, el recuerdo de la historia de la Redención - equivalente a la sintética oración del Credo en la iglesia - sirve también de catequesis para facilitar la comprensión del misterio de la Eucaristía por parte del espectador, a la vez que cumple la función de dar sentido alegórico al argumento ${ }^{35}$. El mejor ejemplo, por contener la mayor pluralidad de significados de la historia de la Salvación, es la loa de La Hermandad del Refugio. En ella, la Fe y la Esperanza leen a la Caridad, para que ésta les dé un remedio, los memoriales que han entregado varios menesterosos madrileños. La situación responde fielmente a la historia del siglo XVII y, sin embargo, el dar a esos necesitados nombres de historia sagrada hermosea el plano historial y, al mismo tiempo, lo enlaza con el plano alegórico, en el que se puede descifrar entonces una sucinta historia de la Salvación ${ }^{36}$. En concreto, la Caridad recibe memoriales - por este orden - de Adán y Eva, María

${ }^{35}$ En los géneros sacramentales, lo alegórico es tan dramático como lo historial; y así, la historia sagrada utilizada en ese plano no deja de ser también materia dramática y, en consecuencia, necesaria. Por esa razón, no puede obviarse aquí su estudio. Por el contrario, en otro tipo de obras -por ejemplo, en los dramas mitológicos- la alegoría de lo histórico es sólo una segunda lectura posible, pero prescindible, del argumento.

${ }^{6}$ Los nombres de las calles en las que viven los pobres (Amargura, Lavapiés, Cuesta de San Lázaro...), o de los lugares de Madrid a los que les manda la Caridad (las Arrepentidas, la Pasión...), también señalan al lector o espectador la necesidad de una interpretación alegórica de todo el texto. Para el doble significado del espacio en esta loa, vid. I. Arellano, "El espacio historial y místico en los autos de Calderón: la topografía transfigurada", en La dramaturgia de Calderón..., pp. 51-52. 
Magdalena, el paralítico de la piscina y Lázaro, Job, la samaritana, Dimas, San Pablo (citado arriba) y María y Jesús. Aunque no hay un orden cronológico estricto, la enumeración comienza y termina del mismo modo que la historia de la Salvación, y la muerte redentora de Jesús resulta perfectamente inteligible al espectador al recordársele la necesidad de reparación del pecado original:

$$
\begin{aligned}
& \text { CARIDAD }[\ldots] \\
& \text { con que volviendo al principio } \\
& \text { la visita, si al primero } \\
& \text { Adán se dio pan y vino, } \\
& \text { viendo que se da al segundo } \\
& \text { vino y pan, será preciso } \\
& \text { que pasando de cruento } \\
& \text { a incruento sacrificio, } \\
& \text { en la Vitoria de que es } \\
& \text { el Buen Suceso testigo, } \\
& \text { se transustancie de suerte } \\
& \text { su sangre y su cuerpo mismo } \\
& \text { que en vino y pan le adoremos } \\
& \text { glorioso, triunfante y vivo. }
\end{aligned}
$$

La mención algo arbitraria de otros nombres de historia sagrada entre los de Adán y Jesús responde a la idea de la muerte de Cristo como misterio de redención universal. Por eso, se alude a algunos personajes que fallecieron antes de la resurrección, como el paralítico de la piscina y Lázaro, que tuvieron, así, que esperar en el limbo (pp. 45-46), o, por el contrario, a Dimas, que murió con Él, o bien a San Pablo, ya posterior. En todos los casos, la mención de esos personajes condensa unos pocos rasgos distintivos, en los que se mezcla - siempre en el plano alegórico - la fuente bíblica con la tradición de la Iglesia, con el propósito de que el espectador recuerde fácilmente un relato histórico que conoce de sobra y no es necesario repetir; así la conversión de Pablo o la historia de María Magdalena:

$$
\begin{gathered}
\text { ESPERANZA Madalena, ilustre dama, } \\
\text { despojada de vestidos, } \\
\text { adornos, galas y joyas, } \\
\text { a tal miseria ha venido } \\
\text { que apenas un saco tiene }
\end{gathered}
$$

Yten mando a doña Isabel de Rivero, mi compañera colegiada en este convento, si estuviere en él cuando se cobren dichos quinientos ducados, otros cien reales, y sino estuviere, revoco esta manda.

Yten mando a María Blanca y a María López, cincuenta reales y una sábana a cada una; luego que se cobren los dichos quinientos ducados y estén ambas en este convento, y a María Martínez Presada que fue mujer de nuestros padres, también se den cien reales, los cuales son de limosna, no por ninguna vejación que la tuviesen sus mercedes, ni yo tampoco.

Y también pido y suplico a los susodichos me encomienden a Dios y después de cumplidos estos mandos, y lo que quedare es mi voluntad ${ }^{10}$ se me diga de misas por mi alma en altares privilegiados.

Declaro que desde que falleció mi madre y señora, que habrá año y medio que gozo de la renta de los dichos doscientos ducados del Consejo de Indias, que montan trescientos ducados y de ellos he cobrado mil reales, y ahora se me han librado cuatrocientos reales, de lo que otorgo carta de pago este día, ante presente escribano, si fuese la voluntad de Dios Nuestro Señor de llevarme de esta presente vida antes que se cobren. Es mi voluntad de suplicar, como suplico, a las madres que me los presten en el inter - y se cobren y se entierran - en cirios para mi entierro y que para mi cuerpo hagan un ataúd aforrado, y lo demás al cumplimiento de los dichos cuatrocientos reales, se me diga de misas por [197r] mi alma y se les entreguen a las madres la carta de pago para que cobren los dichos cuatrocientos reales y se hagan pago de los dichos seiscientos a su cobranza; esta disposición queda.

Yten de lo demás que se me debe de la dicha merced, y quedare debiendo después de mis días, es mi voluntad de mandar y mando, trescientos reales de limosna por una vez a esta santa casa, para la cena del Santísimo Sacramento, que sea alabado por siempre jamás.

${ }^{10}$ Tachado: "lo que quedare".

LECTURA Y SIGNO, 4 (2009), pp. 61-77 
inmerecida por mi causa, y su Hijo me perdone mis pecados por los méritos de su sacratísimo nacimiento, vida pasión, muerte y resurrección gloriosa, al santo nombre, ángel de mi guarda, y también a San José y a todos los demás santos y santas de la corte del cielo, a cuya honra y gloria - deseando poner mi alma en carrera de salvación - hago y ordeno mi testamento en la forma y manera siguiente:

Lo primero encomiendo mi alma a Dios mismo, que la creó y la redimió con su preciosa sangre, y el cuerpo de la tierra de donde fue formado, y es mi voluntad que después de fallecida mi cuerpo sea sepultado en este convento enterrándose en tierra bajo los cielos que favorecieronme y pido que me entierren y suplico a las monjas prioras, suprioras y consultoras que fueren al tiempo de mi muerte, hagan conmigo lo que con su caridad hacen con las fieles que han muerto en este convento.

Declaro que su Majestad que Dios guarde, hizo mandar a la difunta doña María de Ormaza, mi señora y madre, de doscientos ducados de renta - por vidaen penas de cámara de su Real Consejo de las Indias, que yo las gozo, ya que las dejó mi madre, [196v] que días haya que se la quedaron debiendo quinientos - poco más o menos - los cuales demando por la causa de su testamento, con que haciéndose encargo de la cobranza de ellos las madres prioras, suprioras y sucesivos que fueren del Real Convento y para que soliciten la cobranza, y nombren persona que lo haga y luego que se cobren es mi voluntad se den para la sacristía cien ducados para que se conviertan en lo que fuere voluntad de las madres, y a mi ayuda se den de lo primero que se cobrare cien ducados alcanzándome de días, yten es mi voluntad se den a las madres cien reales. A Nuestra Madre Señora de Gracia, cincuenta reales y a Nuestra Señora la Esperanza, y otros cincuenta reales a Nuestra Señora de la Soledad y para que se conviertan en cera para alumbrar a estas imágenes.

Yten mando a la madre San Gregorio, religiosa de este convento, cien reales. con que reparar el frío

y de amor enferma yace

alimentada a suspiros.

CARIDAD ¿Dónde vive?

ESPERANZA Al Lavapiés.

CARIDAD ¿Qué calle?, que es grande el sitio.

ESPERANZA En la calle del Calvario

$\begin{array}{ll}\text { CARIDAD } & \text { que es en } \\ \text { C...] dirás }\end{array}$

que la lleven mis ministros...

ESPERANZA ¿Dónde?

CARIDAD A la Pasión, que es

de las mujeres hospicio.

(Loa de La Hermandad del Refugio, pp. 41 y 43.)

Como se puede observar en este ejemplo, los personajes bíblicos mencionados pierden toda su historicidad en el plano historial y se convierten en un nombre más dentro de la vida cotidiana madrileña. En el plano alegórico, se desarrolla, en cambio, el sentido histórico y sagrado de ese nombre; aunque la historia bíblica recibe aquí más modificaciones que en su empleo como "menciones y adaptaciones de microtextos bíblicos", ya que este nuevo uso exclusivamente alegórico no se basa ya en la autoridad del texto, sino en su poder evocador y representativo de la historia de la Redención.

Una vez esquematizada, esa historia cumple - tanto en esta pieza como en el plano alegórico del resto de loas sacramentales - una función catequística, cuya obtención es muy similar a la del didactismo religioso derivado de la utilización argumentativa de referencias bíblicas, pues en ambos casos la intención del dramaturgo al recurrir a la historia sagrada es explicar el misterio de la Eucaristía al espectador con el propósito último de aumentar su fe. De este modo, en la loa de $\mathrm{La}$ Hermandad del Refugio, Calderón dilucida ese sacramento situando su origen en los dos acontecimientos principales de la historia de la Redención: la muerte y la resurrección de Cristo. En primer lugar, la Sagrada Forma es la sepultura del cuerpo de Jesucristo: 


$$
\begin{aligned}
& \text { CARIDAD [...] dirás } \\
& \text { que entreguen al improviso } \\
& \text { el cuerpo a su madre y sea } \\
& \text { el sepulcro que dedico } \\
& \text { LAS DOS ¿Dónde? } \\
& \text { CARIDAD [...]. En Corpus Criste, }
\end{aligned}
$$

Esta etiología, que permite a los espectadores la inteligencia de la transubstanciación, nace de la unión de los hechos históricos de la institución de la Eucaristía por parte de Jesús (Marcos 14, 22) y de su entierro (Mateo 27, 57-61), pero añade la apariencia contemporánea debida al plano historial, donde sí tiene cabida la fábula. En segundo lugar, la evocación de la historia de la Redención aclara el carácter salvífico de la Eucaristía, pues ya se ha visto arriba cómo esta loa recuerda que la muerte de Cristo permitió la remisión del pecado original introducido por Adán en el mundo. En definitiva, cualquier intento de explicación de la Eucaristía por parte del dramaturgo recurre de forma inevitable a la historia de la Redención porque la Eucaristía es precisamente la imagen eterna de ese hecho histórico; no en vano la Iglesia la considera memorial de la pasión y resurrección de Cristo.

No se puede hablar, en cambio, de funciones celebradora y laudatoria de la historia sagrada en las loas sacramentales. La celebración y exaltación del misterio de la Eucaristía y, en última instancia, de Dios no es equivalente a la alabanza de la familia real en las loas cortesanas ni tampoco en las sacramentales. Ya se ha visto que Dios no es un personaje histórico como divinidad ni como presencia de Cristo en la Eucaristía. Su alabanza en todas las loas sacramentales es, por el contrario, la exaltación de lo eterno y verdadero frente a lo temporal y circunstancial. El papel que la historia sagrada cumple al respecto es el de catequizar al espectador hasta que se una a la exaltación de lo eterno.
A pesar de ello, Antonia Cáncer ya había testado anteriormente. En el Archivo de Protocolos de Madrid se encuentra una de sus últimas voluntades, datada el 27 de agosto de 1661, firmada por ella y que debió realizar ante una importante enfermedad a la que sobrevivió.

Nos parece útil transcribir - cronológicamente - los testamentos de esta hija de Jerónimo de Cáncer, tanto por la información que contienen, como por las aclaraciones, matices e interpretaciones que pueden derivarse de ambos documentos e influir directamente en la vida y obra de nuestro dramaturgo. En definitiva, creemos que estos documentos hasta ahora inéditos nos permiten revisar, con las reservas normales en estos casos, opiniones anteriormente vertidas por otros críticos y estudiosos de la literatura.

\section{Primer testamento de Doña Antonia Cáncer}

Archivo de Protocolos de Madrid, tomo 8545, fols. 166r-197v.

“[196r] In Dei nomine amén. Sepan cuantos esa carta de testamento, última y postrera voluntad, vieren como yo, doña Antonia Cáncer Ormaza, o en su defecto el curador señor que por mi dijo y administró mi persona y bienes cualesquiera y requerimientos de cuantos hallárense. Nacida de Madrid, hija legítima de don Jerónimo de Cáncer y doña María de Ormaza, difuntos, y porque hallándose enferma en la cama de la enfermedad que Dios Nuestro Señor se ha servido darme, en mi juicio y entendimiento natural, temiéndome de la muerte - que es cosa tan cierta a toda criatura - viniese con incierta hora, creyendo, como firmemente creo en el misterio de la Santísima Trinidad, Padre, Hijo y Espíritu Santo, tres personas distintas y un solo Dios verdadero, y en todo y en ello que también creo y confieso la Santa Madre Iglesia Romana, debajo de cuya fe y creencia estoy y deseo morir como fiel católica cristiana, poniendo por intercesora a la Inmaculada siempre Virgen María, Madre de Dios y nuestra, que fue concebida sin pecado original y que 
“ $\mathrm{D}^{\mathrm{a}}$ Antonia María de Cáncer, soltera, de edad de sesenta y ocho años, hija de Jerónimo de Cáncer y de doña María Ormaza, calle de Santa Polonia, casas de Pedro Posada, murió en diez y seis de julio de mil y seiscientos y ochenta y ocho años. Recibió los Santos Sacramentos. Testó ante Bartolomé Gallardo, escribano real, en diez de dicho mes y año, en que declara le debe Su Majestad, que Dios guarde, treinta mil reales, poco más o menos, de una merced de por vida de doscientos ducados de renta en penas de Cámara del Consejo de Indias, las cuales manda a la Orden Tercera con calidad que se celebren, se digan por mi alma mil misas rezadas y dichas por sus testamentarios al coadjutor y demás hermanos de la Orden Tercera y por heredera a su alma. Dio a fábrica tres ducados." ${ }^{8}$

Desde la partida de bautismo hasta la de defunción habían trascurrido cincuenta y seis años, y no sesenta y ocho, que señala en esta última. Sin embargo, sí es interesante señalar cómo se solicita la renta de "las penas de Indias" o también denominadas en otros documentos "penas de cámara", que se debían a doña Antonia María, y que supusieron para Cáncer uno de los reclamos más insistentes a lo largo de su vida9.

Como era costumbre en aquella época, unos días antes de morir se llamaba al escribano, en este caso, don Bartolomé Gallardo para que doña Antonia María diera su última voluntad en su presencia, el día 10 de julio de 1688 y ya "no firmó porque dijo no poder por la gravedad de la enfermedad y la falta de la vista y a su ruego lo firmó un testigo".

\footnotetext{
8 Vid. Archivo parroquial de San Sebastián, libro de defunciones, 16, fol. $164 \mathrm{v}$

9 Las "Penas de cámara" que se aplicaban por el fisco del Rey Nuestro Señor, supusieron una de las mayores preocupaciones de Cáncer a lo largo de la vida, de hecho en la mayor parte de los documentos relacionados con el dramaturgo figuran como aval para pagar sus deudas. Ya comentamos en otro artículo de qué manera Cáncer reclamó estas penas como principal herencia de su padre Fradique Cáncer, aunque para ello tuvo que recurrir a múltiples testigos, entre ellos a Rojas Zorrilla. Vid. A. Rubio San Román y E. Martínez Carro, «Relaciones entre Rojas Zorrilla y Jerónimo de Cáncer», ARBOR, v. CLXXXIII, no 726 (2007), pp. 461-473.
}

$\mathrm{Si}$, como se ha puesto de manifiesto, no hay diferencia entre las funciones que cumplen el Antiguo Testamento y el Nuevo en las loas sacramentales calderonianas, sino que la variedad de usos depende de factores internos de la pieza dramática, también las menciones de santos, en un contexto similar, cumplen la misma función que las de personajes bíblicos. En ambos casos interesa la sacralidad, acorde con el género dramático y apta para la alegoría y la catequesis. Por tanto, a diferencia de lo que ocurre en el teatro breve cómico, no se incluyen santos de historicidad dudosa, de cuya sacralidad se podría desconfiar; aunque, una vez asegurada su existencia real, no importan otros aspectos como la época histórica en que vivieron.

Naturalmente, en pasajes argumentativos, los santos citados deben ser al mismo tiempo Padres de la Iglesia, porque sólo sus textos tienen la misma autoridad que la Biblia en la tradición católica ${ }^{37}$. La misma función argumentativa, argumental y catequística desempeña la siguiente referencia a San Cipriano, Padre de la Iglesia, que la cita de unas palabras proféticas del rey David:

$$
\begin{aligned}
& \text { GAL. } 4 .^{\circ}-\text { Honra de Dios, Ciprïano } \\
& \text { a esta Caridad Inmensa } \\
& \text { y a este Divino Temor } \\
& \text { los llama, y en la Nobleza } \\
& \text { Dios, Atributos de su Honra, } \\
& \text { inspiración con que alienta } \\
& \text { su pronunciación la H, } \\
& \text { ¿quién duda que el lugar tenga } \\
& \text { preeminente a todos? } \\
& \text { (Loa de El divino Orfeo, p. 1837.) }
\end{aligned}
$$

E igual que en el caso de los personajes bíblicos, en el plano alegórico, la mención de algunos santos le sirve a Calderón para unir ese plano con el historial y para ejemplificar con fines catequísticos la universalidad de la Redención. De nuevo, La Hermandad del Refugio contiene los ejemplos más diáfanos. Así, en esta loa, la

37 "Esta importancia de los Padres [...] tiene que ver también con el deseo de garantía ortodoxa frente
a corrientes protestantes defensoras de la libre interpretación" (I. Arellano, Estructuras dramáticas y alegóricas..., p. 62). 
Caridad reside - como no podía ser de otro modo ${ }^{38}$ - en el Postigo de San Martín, "que es quien parte / la capa con el mendigo"39; mientras que los santos Justo y Pastor, Agustín y Úrsula se encuentran entre los menesterosos con los que el dramaturgo evoca la historia de la Redención ${ }^{40}$.

${ }^{38}$ Es muy frecuente en el Siglo de Oro la identificación iconográfica entre San Martín y la Caridad. Vid. A. Egido, "Visajes de la pobreza en el Siglo de Oro", en De la mano de Artemia. Literatura, Emblemática, Mnemotecnia y Arte en el Siglo de Oro, Palma (Mallorca), José J. de Olañeta / Universitat de les Illes Balears, 2004, p. 162

${ }^{39}$ Loa de La Hermandad del Refugio, p. 32.

${ }^{40}$ Vid. ibid., pp. 52-56.
Desde estas premisas no cabe duda de que la única heredera del ingenio merecía una investigación más detallada, con el fin de completar y ampliar la biografía auténtica y real del dramaturgo. Esta es la causa por la que consideramos de interés continuar nuestras investigaciones por este camino.

En este artículo aportamos otros tres documentos inéditos referidos a esta hija del poeta. Uno de ellos la partida de defunción que -junto a la partida de bautismo - se conserva en el Archivo de la Iglesia de San Sebastián de Madrid. Además mostramos dos testamentos, de los cuales sólo el último se menciona en la partida de defunción, mientras que el primero es fruto de las investigaciones llevadas a cabo en el Archivo de Protocolos de Madrid.

La partida de defunción data del 16 de julio de 1688, y aunque en ella figura el nombre de Antonia María Cáncer, se trata de la misma Antonia Bernardina Cáncer - nacida en 1632 - de acuerdo con lo contenido en el testamento.

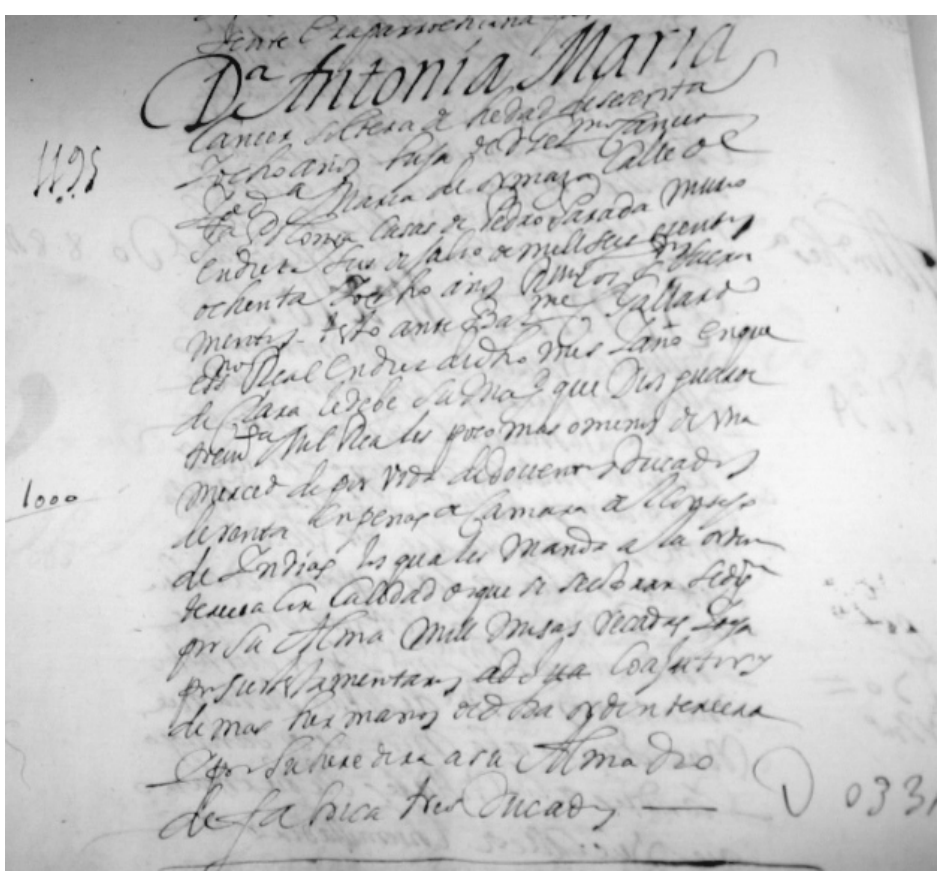


Los vestigios documentales de la familia se pierden hasta el testamento de doña María Ormaza, que nombra como "universal heredera" a la única hija que -al parecer - sobrevivió al matrimonio:

[...] Declaro, que Su Majestad (que Dios guarde), me hizo merced y a doña Antonia Cáncer, mi hija legítima y del dicho Don Jerónimo Cáncer, mi marido, de doscientos ducados de renta. Durante nuestras vidas de mí y de la dicha Doña Antonia, mi hija situados en Penas de Cámara del Consejo de Indias, y de sus corridos se deben y están por pagar más de quinientos ducados. Es mi voluntad y se haga diligencia en su cobranza, y consiguiéndolo se me digan quinientas misas de indulgencia por mi alma y la del dicho Don Jerónimo, mi marido y por algunos cargos de obligación que tuviere de que no me acuerdo. Y para cumplir y pagar este mi testamento y lo en el contenido, dejo y nombro por mi albacea y testamentaria a Doña Ana Centeno, mi madre, a quien doy mi poder cumplido cual le tengo, $\mathrm{y}$ para que entre en mis bienes y los venda y remate en pública almoneda o fuera de ella y de su valor cumpla y ejecute este testamento, y le dure este cargo todo tiempo necesario, aunque sea pasado el derecho concede y cumplido y pagado, o sea y en el remanente que quedare de todos mis bienes y muebles y raíces derechos y acciones. Instituyo por mi universal heredera en todos ellos a la dicha doña Antonia Cáncer, mi hija legítima y del dicho Don Jerónimo Cáncer mi marido, para que los halle y herede. Con la bendición de Dios y de la mía. ${ }^{7}$

A la vista de estos documentos conjeturamos pues, que la mayoría de los hijos de Jerónimo de Cáncer y María de Ormaza ya habían muerto, al no mencionarse ninguno de ellos en este testamento - ni tener, por otra parte - conocimiento de algún otro testimonio que nos permita justificar su supervivencia más allá que la de sus padres.

De igual forma, y volviendo a las referencias literarias sobre los hijos de Cáncer, hoy por hoy, es más razonable pensar que algunas, si no todas sus composiciones en las que se alude a su hija, -y más concretamente los versos que desde Cotarelo vienen citándose - se refieran a Antonia María y no a Polonia, de la que no tenemos más información que la partida de bautismo. Si algún día apareciese el testamento de Jerónimo de Cáncer, quizá haya que cambiar esta opinión, pero mientras los datos documentales no se amplíen - debemos considerar a Antonia María la destinataria de estos versos.

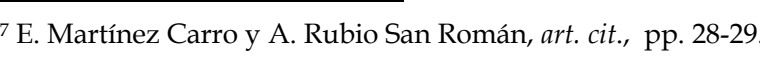

\section{BIBLIOGRAFÍA}

ARELlANO, I., “Para el repertorio de loas sacramentales calderonianas. Un autógrafo inédito de Calderón: la loa auténtica de El Año Santo de Roma", Criticón, 62 (1994), pp. 7-32.

_ Estructuras dramáticas y alegóricas en los autos de Calderón, Pamplona / Kassel, Universidad de Navarra / Reichenberger, 2001.

_ , "El espacio historial y místico en los autos de Calderón: la topografía transfigurada", en I. Arellano y E. Cancelliere (eds.), La dramaturgia de Calderón: técnicas y estructuras (Homenaje a Jesús Sepúlveda), Madrid / Frankfurt am Main, Iberoamericana / Vervuert, 2006, pp. 41-63.

__ y DuARTE, J. E., El auto sacramental, Madrid, Laberinto, 2003.

CAlderón de la BARCA, P., Obras completas. Tomo III: Autos sacramentales, ed. Á. Valbuena Prat, Madrid, Aguilar, 1952.

_ Loa en metáfora de la piadosa Hermandad del Refugio, ed. I. Arellano et alii, Pamplona / Kassel, Universidad de Navarra / Reichenberger, 1998.

CARMONA Muela, J., Iconografía de los santos, Madrid, Istmo, 2003.

Cotarelo Mori, E., Ensayo sobre la vida y obras de D. Pedro Calderón de la Barca, Madrid / Frankfurt am Main, Iberoamericana / Vervuert, 2001.

DíEz Borque, J. M., Teoría, forma y función del teatro español de los Siglos de Oro, Palma de Mallorca, José J. de Olañeta, 1996

__ Los espectáculos del teatro y de la fiesta en el Siglo de Oro, Madrid, Laberinto, 2002.

EgIDO, A., "Visajes de la pobreza en el Siglo de Oro", en De la mano de Artemia. Literatura, Emblemática, Mnemotecnia y Arte en el Siglo de Oro, Palma (Mallorca), José J. de Olañeta / Universitat de les Illes Balears, 2004, pp. 151192. 
ERdocia CAStillejo, C., Hacia una poética de la representación sacramental del Siglo de Oro español: las loas sacramentales de Calderón de la Barca y la celebración del Corpus Christi, Princeton University, 1997 [tesis doctoral].

PARKER, A. A., Los autos sacramentales de Calderón de la Barca, Barcelona, Ariel, 1983.

PedraZA JimÉNEZ, F. B., Calderón. Vida y teatro, Madrid, Alianza, 2000.

RodríGuez CuAdros, E., Calderón, Madrid, Síntesis, 2002.

Ruiz RAMÓN, F., Historia del teatro español (Desde sus orígenes hasta 1900), Madrid, Cátedra, 1996 ( $9^{\mathrm{a}}$ ed.).

RULL, E., "Hacia la delimitación de una teoría político-teológica en el teatro de Calderón", en L. García Lorenzo (ed.), Calderón. Actas del «Congreso Internacional sobre Calderón y el Teatro Español del Siglo de Oro». (Madrid, 8-13 de junio de 1981), Madrid, C.S.I.C., 1983, t. II, pp. 759-767.

_ (ed.), Autos sacramentales del Siglo de Oro, Barcelona, Plaza \& Janés, 1986.

__ , "Instrucción y concelebración populares en el auto sacramental”, en J. Álvarez Barrientos y A. Cea Gutiérrez (eds.), Actas de las Jornadas sobre teatro popular en España, Madrid, C.S.I.C., 1987, pp. 53-63.

__ , "Apuntes para un estudio sobre la función teológico-política de la «loa» en el Siglo de Oro", en I. Arellano et alii (eds.), Apuntes sobre la loa sacramental y cortesana. Loas completas de Bances Candamo. Estudios y ediciones críticas, Kassel, Reichenberger, 1994, pp. 25-35.

_ , "El auto sacramental de Calderón como género. Un ejemplo: Psiquis y Cupido", en A. Egido (ed.), Lecciones calderonianas, Zaragoza, Ibercaja, 2001, pp.125-150.

SIMSON, I., “La función de la alegoría en las comedias de temática americana en el Siglo de Oro", en C. Strosetzki (ed.), Teatro español del Siglo de Oro. Teoría y práctica, Frankfurt am Main / Madrid, Vervuert / Iberoamericana, 1998, pp. 305-321.

SPANG, K., “Aproximación a la loa sacramental y palaciega: notas estructurales”, en I. Arellano et alii (eds.), Apuntes sobre la loa sacramental y cortesana. Loas nos tiene en el estado que estamos! ¿Es mejor estarse haciendo coplillas?" Pero no hemo encontrado registros documentales que certifiquen la existencia de más descendencia. ${ }^{4}$

Como ya demostramos, el matrimonio de María Ormaza y Jerónimo de Cáncer había sido prolífero en el número de hijos ${ }^{5}$, pero todavía mantenemos la incertidumbre sobre la suerte que deparó el destino a cada uno de ellos.

De hecho, sólo conservamos registros documentales posteriores a las partidas de bautismo de una única hija: María Antonia, cuyo bautismo tuvo lugar el seis de mayo de mil seiscientos treinta y dos. Como parece lógico, la mayoría de los hijos debieron morir en edad temprana, pues no hemos encontrado - hasta ahora - más información sobre la descendencia de Cáncer en el lugar donde debería conservarse, la Parroquia de San Sebastián de Madrid'6. En ella se encuentran la partida de matrimonio, las partidas de bautismo de todos sus hijos y la de defunción de Jerónimo Cáncer y María Ormaza. Todos estos documentos ya fueron publicados en el artículo anterior, sin embargo no hemos tenido la misma fortuna para localizar las partidas de defunción de los hijos de Cáncer con las que reconstruir nuevos datos biográficos.

${ }^{4}$ J. Cáncer y Velasco, Obras varias, edición, introducción y notas de Rus Solera López, Zaragoza, Prensas Universitarias de Zaragoza, 2005, pp. XIX y XX

${ }^{5}$ Las partidas de bautismo señalan que don Jerónimo de Cáncer y doña María Ormaza tuvieron, entre otros vástagos, cuatro hijas, nacidas en Madrid: Ana, cuya partida de bautismo señala que nació el 26 de septiembre de 1627, María cuya partida de bautismo afirma que nació el día 25 de febrero de 1631 Un ano más tarde, también en Madrid y en la parroquia de San Sebastián, según consta en la partida, nació Antonia Bernardina, el 6 de mayo de 1632, y la ulte Sa 1 Sja Polona, nacida en febrero vid. E. Martínez Carro y A. Rubio San Román, art. cit., pp. 21-25.

La parroquia de San Sebastián es una de las más antiguas de Madrid. Situada en la calle Atocha, sus demarcaciones han sido muy diversas. La fecha de su fundación oscila entre 1541 y 1550. En un principio su circunscripción fue muy extensa, ya que comprendía un cuadrilátero limitado por una línea que partichdo de la Pueta del Sol ascendia por la calle Alcalá hasta Ventas. Siguiendo desde al el curso del arroyo Abroñigal, llegaba a Vallecas, y luego por el barrio de Lavapiés, pasaba por la plaza del Progreso, subiendo por la calle de Relatores, para terminar de nuevo en la Puerta del Sol. Sin embargo, posteriormente, la Parroquia de San Sebastián fue reduciendo su demarcación hasta ser la parroquia del Barrio de las Musas, donde vivieron Cervantes, Lope de Vega, Góngora, Quevedo, Ruiz de Alarcón, Vélez de Guevara... y por supuesto, Jerónimo de Cáncer, como queda demostrado por la numerosa documentación familiar que se encuentra en el Archivo de la Parroquia de San Sebastián. Vid. J. M. Suárez Sánchez, La Iglesia de San Sebastián. Pequeña historia de una parroquia matritense, Madrid, Espasa-Calpe, 1965, pp. 11-12 
María Ormaza planteaba nuevos enfoques biográficos e interpretativos, no sólo de su vida sino también de su obra.

Sin detenernos en los documentos a los que ya hicimos referencia en el artículo anterior, merece la pena recordar que - en múltiples citas y ocasiones - se han tomado como datos biográficos algunos versos del poeta para justificar que Cáncer tan solo tuvo una hija: Polonia. Cotarelo publicó la partida de bautismo en su Colección de entremeses ${ }^{2}$.

Rus Solera López dedica un apartado de su excelente edición de Obras Varias, al "estudio biográfico" de Cáncer. En él recoge las opiniones anteriores sobre el tratamiento que se ha dado a la descendencia del poeta, a través de unos versos de su obra:

Trascurridos casi diez años desde el enlace, nació en los primeros meses de 1634 una hija, llamada Polonia, según consta en su partida de bautismo. [...] Es posible que dicho nacimiento tuviera lugar el 9 de febrero, festividad de Santa Apolonia, probablemente a esta hija se refiere el autor en la «Carta a un amigo suyo que le encargó que asistiese a una dama que había dejado en Madrid»:

Hasta acostarme, paso entretenido

a mi hija celebrándole algún chiste,

de mi mujer contado y añadido

A partir de dichos versos se ha sugerido que Polonia pudo heredar la ingeniosidad del padre e incluso se ha llegado a afirmar que "era fea más graciosa que él, sutilísima en el arte del retruécano"3. Por otro lado en la reprensión de que su mujer le hace objeto en el Vejamen, está generalizada y habla de "hijos" que se beneficiarían de la secretaría de la Academia que él duda en aceptar: "No está cansado de ser pobre? ¿Por qué no acaba de ser secretario, pues Dios le dio entendimiento? ¿Viénesele la fortuna a casa y no la quiere? ¿No ve que tienen hijos para quien sea? ¿Por qué no acaba de aplicarse? ¡Que su flojedad

${ }^{2}$ E. Cotarelo y Mori, Colección de entremeses, loas, bailes y mojigangas desde finales del siglo XVI a mediados del siglo XVIII, Madrid, Editorial Bailly-Bailliére, 1911, p. LXXXIV.

Destaca en este fragamento la frase de Federico C. Sáinz de Robles -en su contexto- por gratuita: “Fué tal dama doña Maríana de Ormaza, joven viuda y no fea, simpática y muy terne en eso de ayudar al marido en la diaria labor de allegar recursos para su casa exclusivamente con la gracia de la palabra. Y con ella tuvo el poeta una hija fea y más graciosa que él, sutilísima en el arte del retruécano". Hasta el momento no conocemos ningún documento, ni dato real, que aluda de esta forma a la hija de Cáncer. Vid. Federico C. Sáinz de Robles, El Teatro Español. Historia y Antología, Madrid, Aguilar, 1946, p. 820 . completas de Bances Candamo. Estudios y ediciones críticas, Kassel, Reichenberger, 1994, pp. 7-24.

_ _ "El auto sacramental como género literario", en I. Arellano et alii (eds.), Divinas y humanas letras. Doctrina y poesía en los autos sacramentales de Calderón. Actas del Congreso Internacional, Pamplona, Universidad de Navarra, 26 febrero-1 marzo, 1997, Pamplona / Kassel, Universidad de Navarra / Reichenberger, 1997, pp. 469-505.

TIETZ, M., “El «espectador implícito» de los autos sacramentales de Pedro Calderón de la Barca", en I. Arellano y E. Cancelliere (eds.), La dramaturgia de Calderón: técnicas y estructuras (Homenaje a Jesús Sepúlveda), Madrid / Frankfurt am Main, Iberoamericana / Vervuert, 2006, pp. 561-586.

ZAFRA, R., “La «estructura de cuestión» en las loas sacramentales calderonianas”, en I. Arellano y E. Cancelliere (eds.), La dramaturgia de Calderón: técnicas y estructuras (Homenaje a Jesús Sepúlveda), Madrid / Frankfurt am Main, Iberoamericana / Vervuert, 2006, pp. 625-636. 


\section{DOCUMENTOS SOBRE JERÓNIMO DE CÁNCER Y SU FAMILIA (PARTE II)*}

ELENA MARTíNEZ CARRO Y ALEJANDRo RUBio SAN ROMÁN

En el número anterior de Lectura y Signo, su director Juan Matas tuvo la amabilidad de acoger un artículo en el que se aportaban una serie de documentos relacionados con Jerónimo de Cáncer y Velasco.

Era nuestro propósito aclarar algunos hechos acerca de la vida de este dramaturgo del siglo XVII, mediante la publicación de documentos inéditos sobre su biografía y más concretamente de su mujer e hijos ${ }^{1}$. Su numerosa descendencia con

Recibido: 02-01-2008 Aceptado: 03-03-2008

E. Martínez Carro y A. Rubio San Román, «Documentos sobre Jerónimo de Cáncer y Velasco», Lectura y Signo, 2, (2007), pp. 15-32. 
y le hubieran permitido dar una vuelta de tuerca al esquema tradicional de la laus urbium. Ausencias que resultan, cuanto menos, significativas y difíciles de aclarar.

En cualquier caso, capricho poético o estrategia diplomática, las laudes urbium de Miguel de Barrios siguen manteniendo, en sus formas esenciales, la dispositio clásica que le proporcionara Menandro, como hemos podido comprobar en los textos espigados de Coro de las Musas que han ilustrado este trabajo. Los preceptos menandreos se vinculan en el montillano con la abundante información descriptiva vertida por los geógrafos antiguos, Estrabón y Mela fundamentalmente, y con las menciones a una cotidianeidad hispánica que, lamentablemente, sólo era para el judío la sombra de un destierro.

\section{APÉNDICE TEXTUAL ${ }^{52}$}

\section{[I]}

\section{Descripción universal de España} y en particular de la coronada

Villa de Madrid.

\section{METRO I.}

Con la fertilidad que hermosa incluye por los cariños del Favonio España, guardada del león que nunca huye su verde pelo en cano raudal baña tener de Europa lo mejor arguye, tendida en piel de toro, que la engaña en una y otra de Neptuno fuente, dos promontorios puntas de su frente.

52 Ofrecemos a continuación una edición paleográfica de las composiciones más representativas de este particular tributo al subgénero de la laus urbium en la obra de Miguel de Barrios. Para ello nos hemos servido de la editio princeps de Coro de las Musas, es decir, la de Baltasar Vivien, que puede localizarse en la Biblioteca Nacional de Madrid (R-7634) y en la Biblioteca-Fundación «Manuel Ruiz Luque» de Montilla (Córdoba) (15240). He modernizado la ortografía, acentuación y puntuación según la normativa vigente de la Real Academia Española. Por lo que se refiere al uso de mayúsculas, sólo he mantenido aquellas que poseen una relevancia semántica y que, en la mayoría de los casos, pertenecen al acervo mitológico clásico. para disponer mi entierro: me entierre como acostumbra con los demás hermanos de mi calidad, a cuya disposición dejo el dicho mi entierro.

Declaro que por cedula de Su Majestad, firmada de su real mano y refrendada de Juan Bautista Sáenz Navarrete, su fecha de primero de marzo del año de cincuenta y seis, que para en mi poder, están dados y consignados doscientos ducados de renta en cada un año por los días de mi vida, situados en penas de Cámara del Consejo de Indias, en remuneración de los servicios de mis padres y abuelos $^{13}$. Y de lo corrido de dicha merced se me están debiendo más de treinta mil reales que, por ser mujer y sola y no tener quien lo solicite su cobranza, no la he podido lograr. Y siendo Dios servido llevarme, es mi voluntad, que la dicha cantidad que así se me estuviere debiendo y debiere hasta el día de mi fallecimiento, la perciba y cobre la dicha Orden Tercera ${ }^{14}$ para sí y para que la convierta en el culto divino de Santísimo Cristo de los Dolores ${ }^{15}$ que está [fol. 26 r] en la capilla de dicha Orden y en aquello que más necesidad tuviere y que sea del mejor servicio de Dios Nuestro Señor, esto con la obligación de que cobrado que sea las dichas cantidades hagan: se me digan por mi alma y las de mis padres y personas a quien tuviere algún cargo y obligación mil misas rezadas, las cuales digan o hagan decir en la parte o partes que les pareciere a dicha Orden. ${ }^{13}$ Se refiere a su abuelo el capitán don Fadrique de Cáncer, gobernador de la Isla Margarita y Regidor
de Trujillo (Perú), y a su abuela doña Mariana Arce de Velasco.
${ }^{14}$ Posiblemente el testamento alude a la Orden Franciscana Seglar, orden tercera fundada por San
Francisco en 1212, conocida también como Orden de los penitentes o terciarios, que surgió con el fin
de acomodar el espíritu franciscano a las distintas formas no conventuales. Del XIV al XVII, años de
principal esplendor de la orden, fueron numerosas las personalidades que formaron parte de ella
como Galileo, Cristóbal Colón y Lope de Vega.
${ }^{15}$ La capilla del Santo Cristo de los Dolores de la Venerable Orden Tercera de San Francisco tiene su
origen en 1617, cuando los frailes del antiguo convento se decidieron a instalar un templo nuevo e
independiente del reciento conventual. A partir de 1623 comenzaron a reunir terrenos, entre los que
hubo posesiones cedidas como las del Comisariato Franciscano de Indias. La capilla fue construida
entre 1662 y 1668, aunque fue enriquecida con posterioridad, dato que concuerda directamente con el
testamento de nuestra protagonista. En la actualidad es Monumento Nacional después de diversas
restauraciones. 
Por causa de no tener otra cosa alguna de que poder hacerlo, no dejo más misas y dejo encargado y suplicado a dicha Hermandad de la Venerable Orden Tercera me entierre y disponga así de mi cuerpo como sufragios por mi alma a su voluntad, que ésta es la mía.

A las mandas forzosas y acostumbradas un real a todas ellas por una vez, con que las aparto del derecho y hacer en que podían tener a mis bienes.

Declaro que en el colegio que llaman Niñas del Refugio' ${ }^{16}$, en donde asistí de portera, tengo tres pinturas: una, de Santa Teresa; otra, del Cristo en la columna ${ }^{17}$; y la otra, de Nuestra Señora del Populo, las cuales mando a dicho colegio y es mi voluntad se queden para adorno de él. Y pido a las niñas que me encomienden a Dios.

Asimismo es mi voluntad y mando se dé al convento de las religiosas descalzas del Convento Real de Santa Isabel de esta Corte una imagen pequeña de bulto con su peana y trono dorado y dos coronitas y media luna de plata para que la pongan y la coloquen en la parte que a dichas religiosas les pareciere más decente y devota de la iglesia de dicho convento o dentro [fol. 26 v] de él.

${ }^{16}$ Debe entenderse aquí el colegio dependiente del Convento de Santa Isabel, situado cerca de la calle Atocha. Los terrenos que ocupaba el convento de Santa Isabel habían sido parte de una casa de campo del secretario de Felipe II, Antonio Pérez. En dicha finca, una vez confiscados sus bienes por la Corona, se instaló en 1595 un colegio para niños, niñas, pobres, huérfanos y desamparados. A dicha finca se trasladó en 1610 el monasterio de Agustinas Recoletas de la Visitación de Nuestra Señora, undado en Madrid por fray Alonso de Orozco en 1589, que gozaron del favor real de la reina doña Margarita, esposa de Felipe III. Cfr. Leticia Sánchez Hernández, «El convento de Santa Isabel: Madrid 1589-1989», en Real Fundación del convento de Santa Isabel de Madrid, Patrimonio Nacional, 1990, y R. de Mesonero Romanos, El antiguo Madrid, Madrid, Establecimiento Tipográfico de P. Mellado, s.a., p.197. ${ }_{17}$ No podemos descartar que algunas de las obras de arte que aparece en este testamento hayan pasado a formar parte del patrimonio del convento de Santa Isabel, aunque con mucha probabilidad la mayoría desaparecerían con el paso del tiempo, las sucesivas desamortizaciones y el desmantelamiento que este convento sufrió durante la Guerra Civil. Sin embargo, no podemos evitar relacionar algunas de las obras que perviven - y están datadas en la época - con las donadas po Antonia Cáncer. Especial atención merece el Cristo atado a la columna de Antonio Pereda (1611-1678) pintor actualmente reconocido, pero que en su momento fue accesible para el gran público. Vid. Catalogo del IV centenario de la Real Fundación del Convento de Santa Isabel, Madrid, Patrimonio Nacional, 1991. antigüedad o sus principales virtudes. De lograda factura son los dos sonetos-elogio que el poeta dedica a Ámsterdam, o los que destina a su patria, Montilla, París o Madrid. Entre las rarezas que incluyen estas tardías laudes urbium, es interesante traer a colación los sonetos que Barrios engendra en aras de la pretendida paz europea y que explotan la fórmula «Paz entre...» más los dos países referidos en cuestión, a saber, Inglaterra y Holanda, España y Portugal u Holanda y esta última. Curiosa reformulación la de Barrios de un viejo tópico que ya había sido adoptado por Arístides y Dión de Prusa en algunas de sus composiciones.

Para concluir, la configuración del microgénero de la laus urbium en la obra poética de Miguel de Barrios revela la pervivencia, hasta finales del siglo XVII, de uno de los senderos de la laudatio que mejor supieron acomodarse a los intereses literarios y políticos de sus autores. Sin embargo, esta preferencia del montillano por el encomio de ciudades no puede ser definida sólo y exclusivamente en términos estéticos o políticos, pues, de inclinarnos por esta solución exegética, correríamos el riesgo de ofrecer una explicación sesgada de este ejemplo tardío de laus urbium. En el caso concreto de Miguel de Barrios, la correcta interpretación de este particular ramillete de elogios es mucho más compleja de lo que a priori pudiera resultar, ya que nos hallamos ante un autor cuya trayectoria vital posee unas señas de identidad muy determinadas impresas por la experiencia del exilio que habrían de influir en la conformación de su producción literaria. En este sentido, nos sorprende constatar que, al contrario de lo que cabría esperar, Daniel Leví declina en sus laudes un elemento tan sugerente como el lamento del transterrado que, además, hubiera actuado como perfecta catarsis para un alma en litigio permanente. Por otro lado, y teniendo en cuenta la pujanza económica que experimentó la ciudad de Ámsterdam entre los siglos XVI y XVII, a tenor de las numerosas actividades mercantiles establecidas con el resto de Europa, tampoco incorpora Barrios en sus panegíricos estas complejas relaciones que hubieran conferido a sus versos un sesgo muy original 
Con respecto a la laus de Madrid, Miguel de Barrios destaca su localización geográfica, sus orígenes, las denominaciones diversas que ha recibido - echando mano, en este sentido, de unas etimologías más ficticias que reales y de supuestas leyendas fundacionales que sitúan su origen en época romana-, o su pasado romano, visigodo y musulmán. Junto a estos factores de carácter histórico, le interesa al autor referirse a los aspectos más coetáneos que la definen, como la importancia que detenta Madrid por ser Villa y Corte, donde no podían faltar alusiones a sus muchos pretendientes ni a la efervescencia cultural que se prodigaba en las diferentes academias que allí se habían establecido. El encomio concluye con un preciso trazado urbanístico de la ciudad - calles y plazas, fundamentalmente-, los elogios de El Escorial, el Colegio Imperial y el monarca reinante Carlos II y un somero recorrido por Castilla «la Nueva».

Clío, la musa panegírica a la que Miguel de Barrios destina los «Elogios de Ínclitas Ciudades, y Personajes Ilustres»,51 contiene un total de veinte composiciones, donde hilvana su particular laudatio a distintas capitales europeas. Para moldear esta materia encomiástica, alterna el poeta el uso de la octava, que reserva para las laudes más extensas, con la brevitas que le proporciona la arquitectura formal y conceptual del soneto. Al primer tipo pertenecerían los elogios I, II y VII, donde el montillano delinea el Estado Eclesiástico, y la Imperial, y Pontificia Ciudad de Roma, la Corte Veneta y describe la celebrada Italia. Al segundo, en cambio, los diecisiete elogios restantes, donde perfila un bosquejo muy personal del viejo continente desde su exilio holandés, esbozo éste que, obviamente, va a estar definido por sus trazos apátridas.

Así, Barrios acude en sus encomios europeos al mismo procedimiento que ya había esgrimido para las laudes insertas en las descripciones de España y de sus respectivas provincias, sobre todo en las que dedica a Roma, Venecia o la propia Italia. Otras ciudades italianas, como Milán, Bolonia, Trento, Genova o Ferrara son elogiadas, siguiendo la estela menandrea, por su privilegiada situación geográfica, su ${ }^{51}$ M. de Barrios, Coro de la Musas, pp. 177-228.
Asimismo las mando una lámina que al presente tengo sobre hierro, de la oración del huerto, con su marco negro, de cosa de media vara y pido a dichas religiosas me encomienden a Dios.

Asimismo mando y es mi voluntad que luego que yo fallezca y con toda prontitud se dé a doña María Sarabia, persona de mi cariño, en muestra de él y de nuestra amistad y por la necesidad que padece y lo mucho que la debo por estarme asistiendo en mi enfermedad: una basquiña de piel liebre, de color de pasa, tres camisas: una por acabar y las otras dos mojadas ${ }^{18}$ y el vidriado que tuviere al tiempo de fallecimiento, que así es mi voluntad y la pido me encomiende a Dios.

Y para cumplir y pagar este mi testamento, mandas, legados en él contenidas, dejo y nombro por mis testamentarios al Padre Visitador General y coadjutor ministro de la dicha Orden Tercera de Nuestro Padre San Francisco y demás hermanos de ella y cada uno ynsolidum. A los cuales doy poder cumplido para que luego que yo fallezca entren en todos mis bienes y los vendan y rematen en pública almoneda o fuera de ella y de su valor cumplan y paguen esta mi disposición, cuyo cargo les dure todo el tiempo necesario, aunque se ha pasado el que [fol. $27 \mathrm{r}$ ] el derecho dispone, que yo desde luego se le prolongo.

Asimismo es mi voluntad y además del legado que llevo hecho a la dicha doña María de Saravia, se la dé luego de que yo fallezca un mando de dos, que tengo, el mejor, por constarme como me consta: no tiene mando que ponerse.

$\mathrm{Y}$ el remanente que quedare de todos mis bienes, muebles y raíces y derechos y acciones que, por cualquier causa, título o razón que sea, me toquen y pertenezcan dejo, nombro, instituyo como única y universal heredera a mi alma, los cuales quiero que se distribuyan en hacer bien por ella.

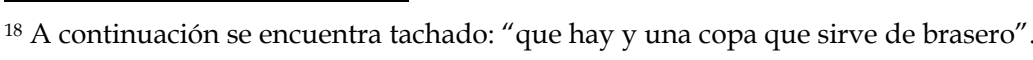

LECTURA Y SIGNO, 4 (2009), pp. 61-77 
Y revoco y anulo y doy por ninguno y de ningún valor ni efecto otro cualquier testamento o testamentos, poder o poderes, para testar $\mathrm{u}$ otra cualquier disposición que haya hecho antes por escrito, de palabra o en otra forma que quiero no valgan ni hagan fe, salvo éste, que al presente hago y otorgo, que quiero que valga por mi testamento, última y postrimera voluntad en la vía y forma que haya lugar en derecho y lo otorgué así; ante el presente escribano en la villa de Madrid a diez días del mes de julio de mil seiscientos y ochenta y ocho. Siendo testigos Joseph [fol. $27 \mathrm{v}$ ] Baltasar de Saravia, don Pedro Ruiz, Antonio Lamar, Marcos Rodríguez, residentes en esta Corte y la otorgante a quien yo, el escribano, doy fe, conozco. No firmo porque dijo no poder por la gravedad de la enfermedad y la falta de la vista y a su ruego lo firmó un testigo.

Estado; romana, que así y una copa que sirve de brasero

Por testigo y a ruego: Baltasar de Saravia.

Ante mí. Bartolomé Gallardo".

Estos dos testamentos, distanciados por 27 años, nos muestran algunos datos biográficos interesantes de la hija de Jerónimo de Cáncer.

La incertidumbre que se deduce sobre el estado civil de Antonia en el primer testamento es manifiesta. Según sus palabras, su situación no deja de ser ambigua, pues, a pesar de su cercanía con la orden de religiosas de las Agustinas Descalzas que vivían en clausura en el Convento de Santa Isabel y con las que manifiesta una total disposición-, no parece formar parte de la comunidad.

De todo ello, y a la luz del segundo testamento, puede interpretarse que Antonia estuviera al servicio de las monjas como hermana portera viviendo - a su vez - en el Colegio de Niñas del Refugio, anexo al convento y fundado por Felipe II.
En la primera parte, Miguel de Barrios principia su descripción con una mención a la fertilidad del suelo hispano - Con la fertilidad que hermosa incluye-, a la que ya se habían referido Estrabón en la Geographia, Pompeyo Trogo en sus Historias filípicas, o el propio San Isidoro en el De laude Spaniae. El montillano recurre a las habituales referencias mitológicas - Ceres, Baco, Vertumno o Pomona - que, como es sabido, son divinidades vinculadas a la feracidad agrícola y, por ende, a la abundancia. No falta tampoco la alusión al viento Favonio - por los cariños del Favonio España-, que, con su suavidad, proporciona a nuestra tierra el clima benigno que ha de favorecer dicha abundancia. Recordemos que Estrabón también había traído a colación al liviano Céfiro como una característica fundamental del templado clima hispano. 49

Aparece después el elogio a la riqueza de sus minas (oro, plata, cobre, hierro) y de su suelo, con las usuales calas en los olivos y las vides, para cerrar esta exposición con las laudes a la abundancia de sus ganados y de pescado en sus costas. A continuación, relata el poeta la historia de España a través de sus diversas conquistas y de los hombres que las protagonizaron. Es precisamente en esta parte donde Barrios va a incluir algunos comentarios sobre los reyes fabulosos Hispán o Gerión, la genealogía bíblica o sobre Túbal, 50 descendiente de Noé y «supuesto» primer poblador de España. Esta tradición legendaria se había iniciado con las Antigüedades judías de Flavio Josefo y sería continuada por otros historiadores como Annio de Viterbo o Pedro de Medina.

El situs que realiza Barrios es muy preciso y se detiene con especial esmero en los distintos ríos que la conforman. El elogio de la diversidad cultural, la fortaleza de sus habitantes, los doctos varones, los militares ilustres, la división territorial y la relación de las distintas provincias hispanas completan la descripción de esta Republica de abejas susurrante, como Daniel Leví la denomina.

${ }^{49}$ Strabon, Géographie, ed. F. Lasserre, Paris, Les Belles Lettres, 1966, vol. I, p. 48 ${ }^{50}$ M. R. Lida de Malkiel, «Túbal, primer poblador de España», Ábaco, 3 (1970), pp. 11-48.

LECTURA Y SIGNO, 4 (2009), pp. 79-106 
En 1672 publica Daniel Leví una de sus obras más logradas, Coro de las Musas, al parecer, en dos ediciones simultáneas, una en Ámsterdam y otra en Bruselas. ${ }^{46}$ El sugerente poemario, que continúa la tradición instaurada por Francisco de Quevedo en el Parnaso español (1648), se escinde en nueve partes - las nueve Musas - , a cada una de las cuales corresponde distintos géneros de poesía. La musa Terpsícore, sin embargo, disiente de su modelo, pues, si en el poeta madrileño esta musa recogía letrillas satíricas y burlescas, más algunas jácaras y bailes, en Barrios acoge la materia geográfica, que se extiende veintiséis composiciones. ${ }^{47}$

Bajo los «acentos serios» de Afro Dionisio y la «dulce melodía» de Luis de Camoens, delinea Miguel de Barrios en octavas reales el «Imperio y las Provincias de España, las cosas notables que sucedieron en el tiempo de sus reyes y dominadores; la genealogía austríaca desde Adán hasta Carlos II y el reino de Portugal, con los monarcas que tuvo hasta el Príncipe don Pedro hoy su Regente». Todos estos «metros» siguen una estructura casi idéntica que obedece a la fértil conjunción de laus y descriptio a la que ya nos hemos referido con anterioridad. A modo de botón de muestra, voy a comentar brevemente la dispositio de la composición lírica que abre el poemario y que se ocupa de la Descripción universal de España y en particular de la Coronada Villa de Madrid. 48

La dilatada descripción, que se extiende a lo largo de veintisiete octavas, se divide en dos partes bien diferenciadas: la referida a España, que comprende las catorce primeras octavas -incluida la laudatio- y la que se ocupa, en las trece restantes, de la Villa y Corte madrileña, donde también inserta el correspondiente encomio de la citada ciudad.

${ }^{46}$ M. de Barrios, Coro de las Musas, Bruselas, Baltasar Vivien, 1672.

${ }^{7}$ Ibidem, pp. 51-176.

${ }^{48} \mathrm{Ibidem}, \mathrm{pp}$. 53-69. El poema completo puede consultarse en el apéndice textual inserto al final de este trabajo. Es el $n^{\circ} \mathrm{I}$.
Este colegio de niñas acogía a jóvenes que habían quedado desamparadas por diversos avatares y que en esta época no tenían otra salida social

Los datos aportados por estos documentos nos llevan a pensar que Antonia Cáncer se refugió en este colegio por encontrarse sola, no sólo sin padres, sino posiblemente también sin hermanos. A su vez, el hecho de que fuera acogida en un patronato real, da cuenta de la deuda contraída con la familia Cáncer por la notable labor de Fadrique Cáncer en América.

A pesar de ello, su refugio no le valió el ingreso en la orden de Agustinas, favorecidas por Felipe III y la reina Margarita, años antes. Como se constata en el segundo testamento - en algún momento comprendido entre los años 61 y 88-, Antonia Cáncer entró a formar parte de la Orden Tercera de San Francisco, seguramente como seglar, por lo que se deduce de sus últimas voluntades, pues de haber pertenecido a la orden reglada las escasas obras de arte que poseía, habrían ido a parar al convento franciscano y no, como consta, al Real Convento de Santa Isabel.

La vida de Antonia debió de ser una vida en soledad y pobreza, como se deja entrever en su testamento. Las deudas que la Corona acumuló con ella, dan medida de la crisis económica del final del Imperio Español. La lucha que una mujer sola debía emprender contra la maquinaria estatal, era desde todo punto imposible; sin embargo, y a pesar de todo ello, hasta el final de sus días contabilizó sus haberes y contribuyó al sostenimiento de las devociones de la época.

Si el tiempo nos lo permite, seguiremos investigando sobre Jerónimo de Cáncer y su descendencia, que, a pesar de ser prolija, parece haber terminado junto al ocaso de un Imperio, como si de una metáfora familiar se tratara, y el fin de siglo acabara con una familia que inició su andadura y su comienzo en las Américas. 
Den Boer, los conceptos de hispanidad y judaísmo. En el caso de Barrios, estas relaciones se hacen, si cabe, más complicadas debido a su desmesurada propensión a la «mendicidad poética», lo que ha llegado a provocar cierta oscilación en el conjunto de su obra e, incluso, la existencia de una maraña ecdótica que dificulta en extremo la interpretación filológica de la misma. ${ }^{42}$

Hasta su muerte en 1701, Barrios monopoliza el panorama literario sefardí desde su establecimiento en Ámsterdam hacia 1660.43 Entre los diversos géneros literarios que cultivó, mostró siempre un creciente interés por el género epidíctico y, en especial, por la laus urbium, que aglutinará en sus obras con minuciosas descripciones geográficas y referencias de carácter histórico. Tanto la Historia como la Geografía fueron siempre dos disciplinas por las que Barrios se sentiría muy inclinado. De ahí que concibiera hacia 1686 un texto como el Triunfo del gobierno popular y de la Antigüedad holandesa, ${ }^{44}$ donde el poeta describe minuciosamente la historia de la comunidad judía de Ámsterdam desde su fundación hasta la época de máximo esplendor, con una fidelidad y precisión históricas que han convertido a dicha obrita en la primera crónica oficial de Ámsterdam y a su autor en el primer historiador de la capital holandesa. ${ }^{45}$ Del mismo modo, Barrios proyectaba la publicación de una Historia Judaica y una Geographia de las diecisiete provincias unidas que refrenda en nuestro autor ese gusto por los estudios historiográficos.

sefardíes de Ámsterdam (siglos XVII y XVIII)», en F. Díaz Esteban (ed.), Los judaizantes en Europa y la literatura castellana del Siglo de Oro, Madrid, Letrúmero, 1994, pp. 65-75, estudio que posteriormente se recogería en La literatura sefardí de Ámsterdam, Alcalá de Henares, Instituto Internacional de Estudios 42 I. García Analusies, Unviversidad de Alcalá, 1996

42 I. García, «Miguel (Daniel Leví) de Barrios: un caso más de "mendicidad poética"», Ámbitos, 9 (2003), pp. 21-27.

${ }^{43}$ I. S. Révah, «Les ecrivains Manuel de Pina et Miguel de Barrios et la censure de la Communauté Judéo-Portuguaise d'Amsterdam», Tesoro de los judíos sefardíes, 8 (1965), pp. 64-91.

${ }^{44}$ M. de Barrios, Triunfo del gobierno popular y de la Antigüedad holandesa, [Ámsterdam], [David de Castro Tartás], 1683. A partir de ahora actualizo la ortografía, acentuación y puntuación según la

normativa vigente de la Real Academia Española.
4 W. Ch. Pieterse, Daniel Levi de Barrios als geschiedschrijver van de Portugees-Israëlietische gemeente te Amsterdam in zijn "Triumpho del govierno popular», Ámsterdam, Scheltema \& Holkema NV, 1968. 
A su vez, Miguel (Daniel Leví) de Barrios ${ }^{39}$ constituye un ejemplo excelente, y original, de la dilatada pervivencia de este subgénero encomiástico a finales del siglo XVII. Poeta, dramaturgo e historiador judío converso nacido en Montilla (Córdoba) en 1635 desarrollará toda su producción literaria en su exilio de Ámsterdam, en el seno de una comunidad religiosa que llegaría a protagonizar una de las eclosiones culturales más importantes de Europa. ${ }^{40} \mathrm{El}$ ingente corpus de textos impresos en la capital holandesa entre los siglos XVII y XVIII, que asciende a unas cuatrocientas ediciones de diversa índole, constituye, sin lugar a dudas, la herencia más preciada de la fecundidad artística de estos sefardíes de Ámsterdam. De alguna manera, podría decirse que la geografía socio-política que definirá dicha comunidad en la mencionada centuria delineará la visión de Europa que el montillano nos proporcione en sus laudes.

Por otro lado, conviene recordar las complejas relaciones de patronazgo judío y mecenazgo hispánico que intervienen en el desarrollo del género encomiástico en la literatura sefardí de Ámsterdam ${ }^{41}$ y que, a mi entender, exceden, como ha señalado

${ }^{39}$ Espigamos a continuación algunos de los trabajos más representativos insertos en la línea de investigación que, desde hace varios años, venimos desarrollando en torno al montillan: La pos a investigacion que, desde hace varos anos, verios, Córdoba de Cónd 2002. Reflexiones biográfico-literarias sobre un judí montillano del siglo XVII: Migued de Cordoba, 2002, «eflexiones biográfico-literarias sobre un judío montillano del siglo XVII: Migue (Daniel Levi) de Barrios", en F. M. Espino Jine (ed.), Actas de las V Jomadas sobre Historia de Marriins y su recepción crítica en Europa», Ámbitos, 12 (2004) pp. 19-24; «Una aproximación Miguel de Barrios y su recepcion cricat poético femenino en el Coro de las Musas de Miguel de Barising , 388: «Notas sobre lo sáríco y lo burlesco en el Coro de los Lusan Un (2007), pp. 27.40, “ De qué se rín los sefardíes de Ámsterdam? Daniel Leví de Barrios la literan, 100 (2007), pp. 27-40, ¿¿ que se rien los sefardies de Ámsterdam? Daniel Leví de Bartios y la literatura satírico-burlesca», in J. Matas Caballero y J. M. Balcells Domenech (eds.), Ceroantes y su tiempo. II Lectura y signo, Anejo I, 2008, pp. 361-370, «La Fábula de Prometeo y Pandora de Miguel (Daniel Leví) de Barrios. Unas notas sobre la diégesis mitica, en prensa.

Hasta hace poco tiempo, tanto la crítica española como la holandesa apenas si habían pasado de puntillas por la obra de estos autores conversos, ignorando de esta forma un capítulo fascinante de la historia literaria europea y, en especial, de la española, pues la inmensa mayoría de sus protagonistas había nacido en suelo hispánico.

${ }^{11}$ H. den Boer, «Las múltiples caras de la identidad. Nobleza y fidelidad ibéricas entre los sefardíes de Ámsterdam», en J. Contreras, B. García e I. Pulido (eds.), Familia, religión y negocio. El sefardismo en las relaciones entre el mundo ibérico y los Países Bajos en la Edad Moderna, Madrid, Fundación Carlos Amberes, 2003, pp. 95-112. H. den Boer también se ha ocupado de estas complejas relaciones en «Más allá de hispanidad y judaísmo. Hacia una caracterización de la literatura hispano-portuguesa de los

\section{EUROPA VISTA DESDE ÁMSTERDAM: LAUS URBIUM EN LA OBRA POÉTICA DE MIGUEL (DANIEL LEVÍ) DE BARRIOS*}

\author{
INMACULADA GARCía GAVILÁN \\ Universidad de León
}

Desde los primeros encomios de ciudades, concebidos en la Antigua Grecia como discursos de carácter público e incluso como un medio eficaz de comunicación política, ${ }^{1}$ hasta los «Elogios de Ínclitas ciudades y personajes ilustres» que Daniel Leví de Barrios compusiera, a finales del siglo XVII, para dar sentido a la Musa Clío de Coro de las Musas, varia ha sido la fortuna de la laus urbium. Su dilatada * Recibido: 24-02-2009 Aceptado: 14-04-2009

1 Como señala F. Gascó en su edición de Menandro el Rétor, Dos tratados de retórica epidíctica, introducción de F. Gascó, traducción y notas de M. García y J. Gutiérrez, Madrid, Gredos, 1996, p. 20 lo que posteriormente se llamaría oratoria epidíctica englobaba en sus comienzos discursos de carácte diverso: fúnebres, elogios de personajes mitológicos o reales sin carácter oficial o elogios de ciudades que sí tenían, por el contrario, un carácter público.

LECTURA Y SIGNO, 4 (2009), pp. 79-106 
pervivencia viene a confirmar que nos hallamos ante uno de los subgéneros más dúctiles y atractivos de la literatura encomiástica, cuyo desarrollo debe ser entendido a partir de la configuración en época helenística del llamado genus epideikticon y de la posterior evolución que sufriría la oratoria encomiástica latina.

Las referencias más tempranas sobre el género del encomio o lo que posteriormente vendría a conformarse como tal, se hallan diseminadas por los tratados de Retórica de la Grecia clásica. En este sentido, aunque la Rethorica ad Alexandrum ya expusiera muy brevemente los rasgos definitorios del elogio y del vituperio y señalara la importancia del recurso de la amplificatio en este tipo de obras, ${ }^{2}$ será Aristóteles quien en su Retórica identifique el género epidíctico como una de las tres especies de discurso, que el retórico interpreta a tenor de la actitud del hablante, del oyente, el tiempo referido y la finalidad que se pretende. ${ }^{3}$ Estos discursos de exhibición encomian o vituperan a una persona o cosa, se refieren al presente, tienen un carácter fundamentalmente ornamental y persiguen la complacencia del espectador. Aristóteles también considera la amplificación como el recurso más apropiado para la consecución del discurso solemne o panegírico.

Sin embargo, el filósofo apenas si realiza unas calas en este género, por tratarse de composiciones que invitan al deleite de los oyentes, concediendo de esta forma una dignidad e importancia superiores a las dos especies de discurso restantes: la deliberativa y la judicial. Además, el Estagirita se muestra interesado fundamentalmente en el elogio de personas, pues no hay ninguna referencia en su Retórica al encomio de ciudades. En este sentido, no parece haber reparado en la fecunda tradición que le brindaba el Panatenaico de Isócrates, a pesar de que algunas de las argumentaciones aristotélicas sobre el género epidíctico pudieran haber tenido

\footnotetext{
2 Retórica a Alejandro, ed. J. Sánchez, Salamanca, Ediciones de la Universidad de Salamanca, 1989, $425 \mathrm{~b} 13$ y ss. y $351440 \mathrm{~b} 1-1441 \mathrm{~b} 19$, respectivamente.

Aristóteles, Retórica, ed. A. Bernabé, Madrid, Alianza, 1998. El filósofo se ocupa del discurso encomiástico en el Libro I, cap. 3 y 9 .
}

clásica y la preceptiva sobre la laus urbium que se impuso a partir de las laudes Italiae y las laudes Romae, a las que hemos aludido con anterioridad. ${ }^{36}$

Sin embargo, este canon cronístico medieval, que concebía la laus urbium como un elemento más de la crónica histórica o geográfica, va a verse sustancialmente alterado por la exhaustiva revisión de datos históricos llevada a cabo en el siglo $\mathrm{XV}^{37}$ y que preconizan autores como Antonio de Nebrija, Cosmografía, Sánchez de Arévalo, Historia Hispanica o Juan Margarit, Paralipomenon. Durante el siglo XVI, Marineo Sículo y Pedro de Medina representan una vuelta al antiguo esquema isidoriano bajo la impronta humanista, aunque tanto De Hispaniae laudibus libri septem como el Libro de las grandezas u cosas memorables de España aborden ya el tema del encomio de una forma independiente, y no como un fragmento de una crónica histórica.

En este sentido, la España defendida (1609) de Francisco de Quevedo es una muestra destacada de la culminación de este panorama que venimos describiendo en torno a la laus urbium, donde el madrileño, movido por un fehaciente nacionalismo y sirviéndose, de forma magistral, de los numerosos elementos que sobre el encomio de ciudades le proporcionaba la Antigüedad clásica, va a elaborar una encendida defensa de España expurgada - y esto sí constituye una novedad importante- de historias fabulosas, en la que, como nos dice el autor madrileño, se leerán los ojos y no los oídos del autor. Pasaremos levemente por el panegírico quevediano y su relación con las laudes Hispaniae, pues ha sido abordado recientemente, con cierto detenimiento, por V. Roncero y a sus conclusiones remitimos. ${ }^{38}$

${ }^{36}$ V. Roncero López, «Las “Laudes Hispaniae”: De San Isidoro a Quevedo», Analecta Malacitana, XVI, 1 (1993), pp. 81-92.

${ }^{77}$ Como nos recuerda R. B. Tate, «La geografía humanística y los historiadores del siglo $\mathrm{XV}$ », en E. de Bustos Tovar (ed.), Actas del IV Congreso Internacional de Hispanistas, Salamanca, Universidad de Salamanca, 1982, p. 691, a propósito de la Cosmografía de Nebrija, «por primera vez en la Península, dio forma conceptual a la visión ternaria de la historia, propuesta hacía un siglo por Petrarca y ejemplifica en el siglo XV en los tomos históricos y cosmográficos de Flavio Biondo y Enea Silvio entre

Otros».
38 V. Roncero López, op. cit., pp. 89-92.

LECTURA Y SIGNO, 4 (2009), pp. 79-106 
The praise of cities is as old as European literature, perhaps I should say the praising description of cities or the praise of cities by jeans of description; for them two are closely related to each other, and while sometimes the element of praise prevails and sometime the element of description, it does not serve any useful purpose, I think, to consider one without the other. ${ }^{31}$

Durante el Humanismo, el encomio de ciudades también experimentaría un auge inusitado, sobre todo a partir de la publicación de la Laudatio Florentiae urbis que L. Bruni incluyera en su Historia Florentina, tradición que sería continuada por otros humanistas italianos como Poggio Bracciolini ${ }^{32}$ o, más tarde, L. Guicciardini, quien compuso una Descrittione di Tutti i Paesi Bassi siguiendo el paradigma clásico establecido por Heródoto en su descripción de Babilonia. ${ }^{33}$

No debemos olvidar que, por lo que se refiere a la crónica, España contaba con un precedente importantísimo, San Isidoro y su De laude Spaniae, que el sevillano coloca como proemio del De origine Gothorum, ${ }^{34}$ continuado y consolidado por el prólogo al Chronicon Mundi de Lucas de Tuy o por la Historia Ghotica de Rodrigo Jiménez de Rada, el Toledano, y la Primera Crónica General de España de Alfonso X el Sabio. ${ }^{35}$ La crónica isidoriana constituía la primera fuente hispánica en que confluyen las dos tradiciones más destacadas del encomio de ciudades y países: las descripciones que de España habían realizado los historiadores de la Antigüedad

31 C. J. Classen, Die Stadt im Spiegel der «Descripciones» und «Laudes urbium» in der antiken und mittelalterlichen Literatur bis zum Ende des zwölften Jahrhunderts, Hildesheim-Zúrich-Nueva York, Georg Olms Verlag, 1986, pp. 4-15.

32 A. Gómez, op. cit., p. 292, señala que, antes que L. Bruni, ya la crónica florentina de F. Villani había adoptado el mismo esquema de insertar el elogio a la ciudad en el marco de una crónica histórica. ${ }^{3}$ C. J. Classen, «Lodovico Guicciardini's Descrittione and the Tradition of the Laudes and Descriptiones urbium», Antike Rhetorik im Zeitalter des Humanismus, München, Saur, 2003, p. 337. Aunque este estudio parte de la obra de L. Guicciardini, ofrece un espléndido análisis cronológico del género de la laus urbium en su relación con la descriptio.

34 C. Rodríguez Alonso, La historia de los godos, vándalos y suevos de Isidoro de Sevilla. Estudio, edición crítica y traducción, León, Centro de Estudios e Investigación «San Isidoro», 1975.

35 J. A. Estévez «Aproximación a los orígenes míticos de Hispania», Habis, 21 (1990), pp. 139-152, y «Algo más sobre los orígenes míticos de Hispania», Habis, 23 (1993), pp. 207-217, ha acometido con detalle el estudio de los orígenes legendarios de Hispania en la obra de Jiménez de Rada, Alfonso X e Sabio hasta llegar a las últimas formulaciones del mito a comienzos del siglo XVII. un precedente importante en la obra encomiástica del autor citado, ${ }^{4}$ sobre todo en lo que se refiere al sentido que éste concediera al término epideixis. ${ }^{5}$ Isócrates se decanta por el tiempo presente en la composición de sus elogios y prefiere los personajes coetáneos a los héroes míticos, confiriendo a sus discursos una acusada dimensión práctica, y política, ausente en el filósofo de Estagira, que irá cobrando mayor importancia en la posterior configuración del elogio de ciudades. ${ }^{6}$

Las observaciones aisladas al género epidíctico que pueden espigarse de estos tratados retóricos preparan de alguna manera el camino para la sistematización de genus demostrativum, donde la laus urbium se convertirá en una de las composiciones más destacadas del inventario de cualquier panegirista. En el marco de la Segunda Sofística, cuyos autores dedicarían buena parte de sus desvelos literarios al panegyricos logos, 7 Menandro el Rétor compone hacia el año 280 d. C. los Dos tratados de retórica epidíctica, que se convertirán en materia de obligada consulta para

${ }^{4}$ La obra encomiástica de Isócrates incluye los siguientes textos: Evágoras, Elogio de Helena, Busiris, Panatenaicos y Contra los sofistas que constituirá una referencia ineludible en el posterior desarrollo del género durante la Segunda Sofística.

${ }^{5}$ F. Gascó, op. cit., p. 22, comenta con acierto que ese significado impreciso de literatura ornamental, de exhibición, que posee el género epidíctico y que ya había sido recogido por Isócrates, hizo posible que todas aquellas composiciones que no se adaptaban a los géneros deliberativo y judicial terminaran formando parte del género laudatorio.

${ }^{6}$ Isócrates, Evágoras, ed. J. M. Guzmán, Madrid, Gredos, 1979, pp. 9-11, se refiere a los muchos (a) procedimientos de ornamentación de que disponen los poetas frente a los oradores, cuyos discursos car 306). Esta cuestión 306. Esta cuestion sera posteriorm

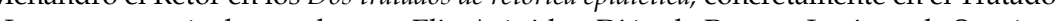

Los autores mas destacados son Elio Arístides, Dión de Prusa y Luciano de Samósata. El primero de ellos es autor de varios discursos epidicticos dedicados al elogio de alguna ciudad -A Cícico, Monodin sobre Esminna, Eleusinio, A Roma y Panatenaico- siendo los dos últimos los que tendrian una repercusión mayor en autores posteriores. Dion Crisostomo -o Dion de Prusa - tambièn cultivo el género de encomio no solo como ejercicio retorico sino también como una forma de divertimento, elogiando las denominadas things without honour, que conforman los encomios paradójicos. Los fragmentos conservados de su Elogio del mosquito o el Elogio de la cabellera, así lo atestiguan. La obra de Luciano, por su parte, nos ha legado tres encomios: dos tradicionales, el Elogio a la patria y el Elogio de Demóstenes, y uno paradójico -a la manera de Dión Crisóstomo- el Elogio a la mosca. A. Ramírez de Verger, «Frontón y la segunda sofística», Habis, 4 (1973), pp. 115-126, recuerda cómo el escritor latino M. C. Frontón asimilará en sus Laudes Fumi et Pulveris y en sus Laudes Neglegentiae esta fructífera tradición helenística del encomio paradójico que siglos más tarde volverá a surgir en muchas de las composiciones satíricas y burlescas de nuestra literatura áurea.

LECTURA Y SIGNO, 4 (2009), pp. 79-106 
acometer cualquier composición panegírica, tanto clásica como moderna. Esta obrita, que por primera vez aborda la epideixis de forma independiente y perfila con detalle las distintas vertientes de la laudatio, dedica suculentas páginas al elogio de las ciudades, cuyos preceptos básicos, como veremos después, se van a mantener en las laudes barrocas.

La división de los discursos epidícticos ${ }^{8}$ se expone al principio del Libro $\mathrm{I}^{9} \mathrm{del}$ Primer Tratado, donde distingue tres tipos de encomio: a los dioses, los denominados himnos, 10 a regiones y ciudades y a criaturas vivas y seres inanimados. ${ }^{11}$ La laus urbium ocupa los libros II y III de este Tratado primero, a lo largo de los cuales el retórico acomete en un escrupuloso discurso cómo elogiar una ciudad. Para Menandro, la alabanza de cualquier ciudad debía incluir siempre una laudatio de la región a la que ésta pertenecía, por eso principia su disertación teórica estableciendo unas directrices básicas para componerla, tomando como punto de partida su situación y naturaleza. Detengámonos un instante en las definiciones que el retórico latino nos proporciona sobre la laus urbium:

Las alabanzas de ciudades son mezcla de los capítulos sobre regiones citados y de los referidos a los hombres. Así, de los referidos a regiones hay que tomar la situación; el origen, las acciones y las actividades, de los referidos a los hombres. Sobre esa base, pues, hacemos el encomio de las ciudades. ${ }^{12}$

El elogio de una ciudad atendería, por tanto, a cuatro factores fundamentales: situación, origen, acciones y actividades. Cada uno de estos aspectos se describe con

${ }^{8}$ Menandro el Rétor considera que los discursos epidícticos son aquellos que se ocupan de la alabanza o del vituperio. Este último constituiría una clase indivisible para el retórico.

9 El libro I de este Primer Tratado se ocupa fundamentalmente de los distintos encomios que se pueden dirigir a los dioses.

Menandro el Rétor, op. cit., pp. 90-109, comenta que, según el tema propuesto, los himnos a los dioses podían dividirse a su vez en invocatorios, de despedida, científicos, míticos, genealógicos, ficticios, precatorios y deprecatorios. Menciona también el autor algunas puntualizaciones estilísticas acerca de los distintos himnos que se refieren, sobre todo, a la pertinencia del uso de la prosa respecto de la poesía en su composición.

${ }^{11}$ Las consideraciones de Menandro en torno a este tercer tipo de elogio, que debiera haber aparecido en el Primer Tratado, no han llegado hasta nosotros, pues sólo se han conservado la preceptiva relativa a la alabanza de dioses y a la laus urbium.

${ }^{12}$ Menandro el Rétor, op. cit., p. 115 durante el Quattrocento, donde cobra mayor sentido con el sistema de ciudadesEstado y sus disputas continuas. ${ }^{28}$ En España, Alfonso de Palencia concibe la epístola De laudibus Hispanis, Jerónimo de Córdoba su Descriptio Cordubae, y, a comienzos del Quinientos, Alonso de Proaza compone la Oratio luculenta de laudibus Valentiae ${ }^{29}$ o el alcañizano Juan Sobrarias su Oratio de laudibus Alcagnicii, inspirado en el De Hispaniae laudibus libri septem - conocido más tarde como De rebus memorabilibus Hispaniaedel humanista italiano Lucio Marineo Sículo. Estas dos últimas laudes son los testimonios más tempranos de este género en los primeros años del siglo XVI y los únicos durante bastante tiempo, ya que, hasta bien entrada la citada centuria, no se localizarán más composiciones laudatorias a otras ciudades españolas. ${ }^{30}$ Esta proliferación textual no hace sino atestiguar un desarrollo de la laus urbium cada vez más arraigado en nuestro país desde finales del siglo $\mathrm{XV}$, que continuará, como hemos visto, durante todo el XVI y va a perdurar hasta bien entrado el siglo XVII en autores como Francisco de Quevedo o Miguel de Barrios.

Además de en la poesía, el subgénero epidíctico de la laudatio urbis podía aparecer en la prosa, vinculada especialmente con las descripciones e historias de ciudades que ya habían aparecido en las crónicas medievales y que solían remitir a las grandes obras de la historia y la geografía clásicas, como la Chorographia de Pomponio Mela, la Geographia de Estrabón, la Naturalis historia de Plinio o la Collectanea rerum memorabilium de Julio Solino, entre otros. Este tipo de composiciones presentaba un destacado hibridismo entre laus y descriptio que hacían muy difícil deslindar el encomio propiamente dicho de la simple descripción. En este sentido precisa C. J. Classen:

${ }^{28}$ A. Gómez, España y la Italia de los humanistas: primeros ecos, Madrid, Gredos, 1994, pp. 287-291.

29 Este texto puede consultarse en J. Ponce, Poetas leoneses del siglo XV, León, Instituto Leonés de Cultura-Diputación Provincial de León, 2001, pp. 119-123.

${ }^{30} \mathrm{~J}$. Sobrarias, Alabanzas de Alcañiz: Discurso del alcañizano Juan Sobrarias pronunciado ante el senado de la villa en el año del Señor de 1506, ed. J. M. Maestre, Alcañiz, Instituto de Estudios Humanísticos / Instituto de Estudios Turolenses, Universidad de Cádiz, 2000, pp. XVII-XVIII. Entre las laudes urbium que menciona el editor podemos traer a colación el De Cordubae urbis origine, situ et antiquitate de Ambrosio de Morales, la Oratio in laudem dulcissimae patriae Ciudad Real compuesta por Juan de Vadillo o el De Antiquaria, patria sua de Juan de Vilches.

LECTURA Y SIGNO, 4 (2009), pp. 79-106 
(Silvae III, 5) de Estacio. ${ }^{24}$ Precisamente este último inaugura la tradición del encomio basado en la comparación hiperbólica, cuyo magisterio seguirán Claudiano, Sidonio Apolinar o Venancio Fortunato. ${ }^{25}$ Rutilio Namaciano, aunque es un poeta tardío, constituye también un precedente curioso para la posterior configuración de la laudatio urbis, pues introduce en su De redito suo un elogio a Roma inserto en un himno. ${ }^{26} \mathrm{Si}$ recordamos que, según la preceptiva menandrea, los himnos estaban reservados sólo y exclusivamente para elogiar a los dioses, vemos que algunos de estos autores - como R. Namaciano - se decantaban más por un acusado hibridismo genérico que por fórmulas estereotipadas en la elaboración de sus encomios. De alguna manera, eran estas pequeñas «licencias» - la comparación hiperbólica, una leve modificación en la dispositio habitual, etc. - las que evitaban que el género cayera en el estancamiento y terminara por desaparecer.

Toda esta preceptiva clásica sobre el encomio de ciudades, que ha sido analizada con cierto pormenor en las páginas precedentes, será incorporada por los autores europeos de la Antigüedad tardía y la Edad Media en sus respectivas obras encomiásticas. En esta época el discurso panegírico encuentra en la lírica uno de sus cauces compositivos más atractivos, pues, como afirma Curtius, «los elementos estilísticos del panegírico pueden aparecer en todos los géneros y en todos los temas de la poesía».27 Los autores italianos se mostraron especialmente proclives a la alabanza de las ciudades. En efecto, se conservan elogios muy tempranos de Milán, Verona, Roma, Florencia y demás ciudades de Italia, como integrantes de un género que empezará a desarrollarse en el Trecento y vivirá su época de máximo esplendor

${ }^{24}$ Estacio, Silvas III, ed. G. Laguna, Sevilla, Servicio de Publicaciones de la Universidad de Sevilla, pp. 102-105. Ovidio, Amores. Arte de amar. Sobre la cosmética del rostro femenino. Remedios contra el amor, ed. V. Cristóbal, Madrid, Gredos, 1989, p. 288. Marcial, Epigramas, ed. J. Fernández y A. Ramírez deVerger, Madrid, Gredos, 1997, vol. I, pp. 135-137.

25 E. R. Curtius, op. cit., p. 236, se refiere a esta técnica con el nombre de «sobrepujamiento» (Überbietung) que en la pluma de Estacio se convertirá en un hábil recurso en la composición de los encomia.

${ }^{26}$ Namaciano, Rutilio, El retorno. Geógrafos latinos menores, ed. A. García-Toraño Martínez, Madrid Gredos, 2002, pp. 45-50.

${ }^{27}$ E. R. Curtius, op. cit., p. 227. Como señala el crítico, el discurso panegírico -cuyo tema fundamental es la alabanza- fue el que más influyó en la poesía medieval. minuciosidad e incluso se ilustra con ejemplos cuidadosamente espigados de las obras de los autores de la Segunda Sofística, ${ }^{13}$ siendo el Panatenaico o los panegíricos a Esmirna o Roma de Arístides las más citadas por Menandro, por ser consideradas, ya entonces, modelos excelentes para la imitatio en materia epidícitica.

Así, la situación vendrá determinada por el cielo y las estaciones, el continente y el mar, las montañas o llanuras, las regiones o ciudades vecinas, etc., que se regirán por el placer y la utilidad que a la ciudad proporcionen. ${ }^{14}$ La alabanza de una ciudad en cuanto a su origen deberá incluir sus fundadores, sus habitantes, el tiempo, los cambios y las causas por las que las ciudades se habitan. Cada uno de estos tópicos, como el propio autor los denomina, es susceptible de ser dividido en diversas partes, clasificación que, por incluir una información muy valiosa, será posteriormente utilizada con habilidad por los cronistas medievales en sus laudes. ${ }^{15}$ Por último, una ciudad también es encomiada por sus actividades, que el retórico latino relaciona con la constitución política, los saberes, las artes o las capacidades de la ciudad en cuestión.

Sin embargo, y pese a la minuciosidad de Menandro en su exposición de la preceptiva sobre la laus urbium, apenas si dedica unas cuantas apreciaciones a la praxis de este subgénero epidíctico, es decir, a aquellas ocasiones en las que era pertinente traer a colación un discurso encomiástico de semejantes características. ${ }^{16}$

${ }^{13}$ Como apuntan M. García y J. Gutiérrez, op. cit., p. 111, n. 97, debemos tener en cuenta que, cuando Menandro dedica estas páginas de su Tratado I al elogio de las ciudades, ya existían destacados precedentes de este género tanto en verso como en prosa, sin olvidar la importancia de las descripciones geográficas llevadas a cabo por los historiadores. Junto a los Progymnásmata, e Antióquico de Libanio parece ajustarse con fidelidad a esta tradición.

${ }^{4}$ Menandro el Rétor, op. cit., pp. 115-116.

${ }^{15} \mathrm{Ibidem}, \mathrm{pp}$. 123-124, aduce los siguientes ejemplos para apoyar esta clasificación: « (...) por ejemplo si investigamos quién fue su fundador, si dios, si héroe, si hombre, y, a su vez, de acuerdo con su condición, si general, rey o un particular. Bien, el encomio será el más solemne si fuera un dios, a la manera que se dice sobre algunas, como Hermópolis, Heliópolis y las que son por estilo; si fuera uno de los semidioses o héroes convertidos después en dioses, menos solemne el encomio, pero igualmente glorioso, como Heraclea y cuantas fundaron Sarpedón, Minos u otros héroes; y si hombre, en el caso de que sea un general o un rey, glorioso; si un particular, modesto y sin esplendor.

${ }^{16} \mathrm{~L}$. Pernot, «Les topoi de l' éloge chez Ménandros le Rhéteur», Revue des Études Grecques, 99 (1986), p. 49 , señala esta falta de pragmatismo como uno de los rasgos que diferencia ambos opúsculos

LECTURA Y SIGNO, 4 (2009), pp. 79-106 
En este sentido, concluye que «los encomios son, unos, generales para toda ocasión y, otros, especiales para circunstancias concretas: especiales para circunstancias concretas, cuando los discursos tengan lugar en fiestas, festivales, en un certamen o en espectáculos de gladiadores; generales, cuando no tengan ningún motivo de esta clase». ${ }^{17}$

Será Quintiliano ${ }^{18}$ quien, en el capítulo VII del Libro Tercero de su Institutio Oratoria dedicado al genus demonstrativum (Laude ac vituperatione), ${ }^{19}$ considere con cierto pormenor esta dimensión práctica, y política, de la literatura encomiástica que estaba ausente en sus antecesores. Aun reconociendo la aportación helénica al género epidíctico, de Aristóteles y Teofrasto sobre todo, el empleo de la laudatio con fines políticos y sociales sería una contribución exclusivamente romana a la oratoria encomiástica: sed mos Romanus etiam negotiis hoc munus inservit. ${ }^{20}$ La tradición de las laudationes funebres, en la que el autor calagurritano se sustenta para exponer su argumentación y que había sido concebida en época republicana con una intencionalidad claramente política, hace virar la arquitectura teórica del elogio que, además de poder tener una finalidad ornamental o de exhibición, como ya había propuesto Aristóteles, ahora podía acomodarse también a objetivos más cívicos. Al ampliar el universo temático del encomio propuesto por Menandro, que ahora contempla mayor diversidad de asuntos y procedimientos estilísticos, Quintiliano

menandreos. El segundo tratado, en cambio, posee una orientación práctica más acusada y proporciona amplia información sobre las circunstancias histórico-sociales que rodeaban la exposición de los discursos comentados. Para un análisis exhaustivo en torno al genero encomiástico, véase Pernot, La rhétorique de l' éloge dans le monde gréco-romain, Paris, Institut d' Études Augustiniennes, 1993,2 vols.

Menandro el Rétor, op. cit., p. 143. Seguidamente, y a propósito de los discursos de festivales, el retórico se refiere a la pertinencia de «recrearse con el mayor detenimiento en torno a la circunstancia concreta: por ejemplo, si fuera una fiesta, un festival o un encuentro multitudinario con motivo de un certamen de armas, atlético o musical». Algunas pinceladas sobre las circunstancias en las que se producían este tipo de discursos cierran este libro tercero del tratado primero.

${ }^{18}$ Antes de la obra de Quintiliano, los tratados de retórica latina apenas si se detienen en el género epidíctico y, cuando lo hacen, siguen manteniendo el modelo retórico helenístico. Tal es el caso de la Retórica a Herennio o de Cicerón en el De oratore.

19 Quintiliano, Obra completa, ed. A. Ortega, Salamanca, Universidad Pontificia/Caja Salamanca y Soria, 1996, vol. I, pp.386-397.

${ }^{20}$ Quintiliano, op. cit., p. 386. asimila el encomio de personas y ciudades, otorgando a éste último idénticas características:

Por otra parte, las ciudades son objeto de alabanza, como los hombres. Pues en lugar del padre está el fundador, y alto timbre de autoridad le otorga la antigüedad, como en el caso de aquellos de quienes se dice haber nacido de la tierra; también las virtudes y los vicio son precisamente en sus merecimientos igual que en las personas particulares: se trata de aquellas propiedades que pertenecen a la situación del lugar y a su fortificación. ${ }^{21}$

Fundador, antigüedad, y virtudes y vicios, serían, por tanto, los tres aspectos fundamentales sobre los que debe basarse el encomio, concediendo una relevancia especial al situs o localización geográfica de la ciudad. ${ }^{22}$ Con estos escuetos principios teóricos Quintiliano establece un paradigma de laus urbium de vital trascendencia para las letras latinas, cuyo refrendo teórico viene de la mano de Teón en los Progymnásmata y de la obra del mismo nombre atribuida a Hermógenes, que posibilitaron la sistematización de los rasgos definitorios del encomio de ciudades, y demás subgéneros de la oratoria epidíctica, ilustrados con multitud de ejemplos. Asimismo, todo este proceso favorecerá el inusitado auge que, ya en época clásica, experimentan las laudes Romae y las laudes Italiae, que van a seguir muy de cerca el modelo adoptado por Virgilio para este tipo de composiciones en las Geórgicas. ${ }^{23}$

Sería prolijo traer a colación todos y cada uno de los textos que contienen algún elogio de estas características, pero sí pueden mencionarse los más representativos: la laudatio de Sulmo de Ovidio, el de Bílbilis de Marcial o, especialmente, el encomio a Campania y Nápoles incluido en la Ecloga ad uxorem

${ }^{21}$ Ibidem, p. 397. La cursiva es mía.

${ }^{22}$ Una valiosa obra de conjunto en torno al género del relato etnográfico sigue siendo la de R. Thomas, Lands and peoples in Roman poetry. The etnographical tradition, Cambridge, Cambridge Philological Society, Suplement 7, 1987.

${ }^{23}$ E. R. Curtius, Literatura europea y Edad Media latina, México, Fondo de Cultura Económica, 19844, pp. 228-229, ya comentaba que «Conocida es la popularidad que ya en época romana tenían las laudes Italiae y las laudes Romae. La teoría literaria de la tardía Antigüedad precisó minuciosamente los preceptos del panegírico de ciudades; había que alabar primero la situación de la ciudad y enumerar luego todas sus demás ventajas, sin descuidar su cultivo del arte y de la ciencia».

LECTURA Y SIGNO, 4 (2009), pp. 79-106 
fue, dice, un rechazo espontáneo a la violencia policial: «fue que, de meses atrás, tenían fábricas de bombas, y andaban con ellas en los bolsillos «en espera del buen momento»» (56). Por ello, y por la instigación constante a la violencia a la que sometían a sus compañeros es que, según el cubano, «(n)o embellece esta vez una idea el crimen» (56).

Al igual que en la crónica anterior se invalida la representatividad de los líderes huelguistas y se los reconoce como falsos obreros que «dándose a sí propios como excusa de su necesidad de destrucción las agonías de la gente pobre, no pertenecen directamente a ella, ni están por ella autorizados, ni trabajan en construir como trabaja ella» (58). La crónica no muestra a estos inmigrantes integrados a la sociedad americana, pero tampoco los muestra deseosos de estarlo. Contrariamente a esto, se los describe desplegando su ímpetu destructivo apenas llegan a Estados Unidos. El hombre que hizo la bomba, por ejemplo, «no llevaba más que unos nueve meses de pisar esta tierra que quería ver en ruinas» (55). Desconocía la diferencia que el cronista marca en reiteradas oportunidades entre las reglas del juego social de Norteamérica y Europa. Las soluciones a los conflictos sociales no pueden trasladarse porque estos dos espacios son antitéticos y, como en la crónica anterior, representan respectivamente el lugar de plenitud y el de la estrechez social.

Los inmigrantes que protagonizan el conflicto con la policía vienen de «países donde los que padecen no tienen palabra ni voto» (56). Sus artículos y discursos no tienen en Estados Unidos, según el cronista, «aquel calor de humanidad que revela a los apóstoles cansados, a las víctimas que ya no pueden con el peso del tormento y en una hora de majestad infernal la echan por tierra» (57). Perdieron legitimidad desde la perspectiva martiana al transgredir la legalidad republicana que su discurso invoca y pondera frecuentemente.

Los problemas de los trabajadores de uno y otro lugar no son comparables ni compatibles, y por ello «(l)os obreros norteamericanos miraron como extraños a esos
Embiste a Francia, donde con nevado rejón sale el Cierzo riguroso,

per

y por las otras partes el mar coso;

del que nació de Juno no engendrado

el silvo le embravece belicoso:

Jove le amansa, echándole benigno

la etérea capa del noveno signo.

Llama a su Elisia amenidad, Homero, de almas gloriosas Paraíso, en cuanto tira flechas de paz el Dios arquero,

y vidas une el Himeneo santo;

Pomona ofrece a su galán ligero gustosos frutos con florido manto: tienen Ceres y Baco dulces lides, toda áureos granos, todo alegres vides.

En las opacas venas que la estulta Codicia rompe con lancetas de arte, metal inquieto Trimegisto oculta, Delia, plata, oro Febo, y hierro Marte. A su hilador artífice sepulta cuanto el Catay capullo le reparte.

A la ingeniosa Aracne le devana mártir lino Isis, Palas rica lana.

República de abejas susurrante, por lo interior de cera al corcho mura y encubre cómo, cuerda, y vigilante da de la flor libada la dulzura. De óleo, y blanco licor región manante,

recrea en la corriente y la espesura con varias pescas al sagaz barquero, con nobles cazas al veloz montero.

Todo vistosa la región ostenta que por el rey Hispán se nombró España de ingenios doctos cátedra opulenta, de fuertes héroes militar compaña; varias provincias conquistó sangrienta inculcó la del indio tierra extraña, dándole siempre triunfos laureados las armas y varones señalados. 
Al mar Mediterráneo corresponde por la parte que el flavo Apolo viene y a los franceses límites, por donde viste de escarcha el Boreas a Pirene; en esta banda, y la que el Sol esconde, toca el raudal de Atlante: $\mathrm{y}$ del Sur tiene aquel mar, que del tórrido african

la aparta con el golfo gaditano.

De sus celebres ríos, la recrea

el rojo Miño: el Duero caudaloso;

Ebro que en Reinos ínclitos campea;

corriente Llobregat; Ter generoso;

Betis, que a los Elisios lisonjea;

Tajo en Castilla y Portugal undoso;

Júcar bravo en la tierra valenciana

y con natural puente Guadïana.

Fuerte si lucha, aguda si conversa,

siempre asombró con potestad ferina

por cuanta la ocupó nación diversa

su riqueza ocasión de su ruïna;

habló en lengua caldaica, egipcia, persa,

hebrea, griega, arménica, latina,

gótica, y agarena, y hoy sus gentes

mezclan todo en idiomas diferentes.

Los sacros fueros de Noé sostuvo

más de tres siglos, hasta que la vana

Idolatría que el egipcio tuvo

por Gerión, cegó a la gente hispana;

con aquellos Cantabria se mantuvo,

hasta cuando alcanzó la fe cristiana

el héspero, al pontífice obediente,

y Santïago su patrón valiente.

sintió después los bélicos rigores

de varios extranjeros codiciosos;

pasó a sesenta y cuatro emperadores,

a godos reyes treinta y tres briosos,

y los moros, quitándola a Rodrigo

desunidos formaron su castigo. de ellas no son sino opiniones subjetivas sobre sus figuras que retoman las isotopías trabajadas en la crónica anterior del odio y del transplante inmigratorio negativo. Martí sostiene que ellos son «meras bocas por donde ha venido a vaciarse sobre América el odio febril acumulado durante siglos europeos en la gente obrera» (55), y que «han traído de Alemania cargado el pecho de odio» (55), expresión que repite casi literalmente una de la crónica anterior, en la que enunciaba que estos inmigrantes «se han venido de allá con un taller de odio en cada pecho» ("Grandes motines obreros" 447).

La procedencia europea de los anarquistas como factor explicativo y determinante de su comportamiento social es tan importante para el planteamiento del cronista que éste llega a referirse en el primer párrafo a «aquellos siete alemanes» (55) a pesar de que sólo unas líneas más adelante rectifique esta información al reconocer que uno de ellos, el que está «casado con una mulata que no llora, es norteamericano, y hermano de un general de ejército» (55).

Los anarquistas se dibujan por oposición a valores sociales y legales que en la crónica se admiten como válidos. A la paz social ellos le oponen la violencia que difunden y reproducen tanto a través de los enfrentamientos armados como de una labor pedagógica mediante la que enseñan y transmiten los instrumentos para echar abajo material y simbólicamente no sólo el modo de organización laboral estadounidense sino también su orden social republicano. Desde que llegaron, sostienen Martí, ellos «se pusieron a preparar la manera mejor de destruir» (55): imprimiendo «libros en que se enseña la manera fácil de hacer en la casa propia los proyectiles de matar» (56) y editando bibliografía doctrinaria.

«En libros, diarios y juntas adelantaban en organización armada y predicaban una guerra de incendio y de exterminio contra la riqueza y los que la poseen y defienden, y contra las leyes y los que las mantienen en vigor» (56) relata Martí, que considera agravado el ataque contra la policía por su carácter predeterminado. No 
crimen e informa sobre la constitución del jurado, el juicio y el veredicto final. Continúa la perspectiva descriptiva y reflexiva de "Grandes motines obreros", pero la focalización del repertorio actorial es más específica, tal como desde el título se indica. Repite este texto la idea de que en el movimiento obrero coexisten, en conflicto, dos tendencias antagónicas: la de los moderados y la de los radicalizados, pacifistas y violentos, respetuosos e irrespetuosos de las leyes republicanas, respectivamente.

"El proceso de los siete anarquistas" retrata a los anarquistas, esta vez procesados y condenados, de un modo detallado y explícitamente axiológico. Los deícticos que afectan la mención de estos sujetos funcionan, al igual que en la crónica anterior, como marcas de distanciamiento ideológico que refuerzan los calificativos negativos. Martí se refiere a estos obreros como a «aquellos míseros, incapaces de llevar sobre su razón floja el peso peligroso y enorme de la justicia» (55). A las predicaciones sobre los anarquistas que se ofrecen en el primer y extenso párrafo se le suman otras referidas a su accionar. Martí cuenta que:

aquellos que construyeron la bomba, que convocaron a los trabajadores a las armas, que llevaron cargado el proyectil a la junta pública, que excitaron a la matanza y el saqueo, que acercaron el fósforo encendido a la mecha de la bomba, que la arrojaron con sus manos sobre los policías (...) han sido condenados, en Chicago, a muerte en la horca (55).

La información de los hechos que se brinda a través de las proposiciones subordinadas adjetivas enumeradas cobra una acentuada vivacidad por la yuxtaposición que, al eliminar los nexos sintácticos, comunica una sensación de apresuramiento y de rapidez muy acorde con el ritmo de vida de la ciudad moderna y de la propia tarea periodística. El movimiento de éste y otros pasajes muestra que, tal como observa Fina Marruz, en la escritura martiana estadounidense «todo se inserta en un nuevo dinamismo» (180).

Algunas de las predicaciones brindan datos objetivos sobre los anarquistas: nombres, nacionalidades, hechos imputados y castigo asignado, pero una gran parte
Distinta España en reinos diferentes, obtuvo opuestos solios separados, hasta que rey de sus diversas gentes Felipe el Sabio los gozó enlazados; componen su diadema permanentes quince títulos regios, dos condados, dos principados, mitras obispales cincuenta y seis, con once arzobispales.

Su basa Oviedo es, León su corona Toledo y Burgos, tronos de Castilla; de Navarra metrópolis Pamplona; de Aragón Zaragoza insigne silla; de Cataluña escudo Barcelona; del mar la Palma de oro maravilla Valencia rara en cuanto fruto hospeda; y celebrada Murcia por la seda.

Rica Lisboa en Portugal se ostenta Compostela en Galicia clara luce; en Vandalia Sevilla fiel se asienta gran nobleza en sí Córdoba deduce; fructífera Granada se acrecienta la oliva de Minerva Jaén produce; Gibraltar por su Estrecho cobra fama y por suerte Algeciras real se llama.

Resplandece entre todas dominante, como entre los planetas el dorado

Febo, Madrid con majestad triunfante de Toledo en el rico arzobispado: ilustra populosa el abundante margen del Manzanares celebrado, dentro de la provincia carpetana, con la admirable puente segoviana.

Del Lacio tiberino hijo valiente

Ocno Bianor edificó lozano

esta Villa, metrópoli excelente en el centro feliz del clima hispano: bajo de Sagitario y el rugiente signo, con aire puro y temple sano, a España ofrece esfuerzo y agudeza, de corazón sirviéndole y cabeza. 
De la adivina Manto la llamaron

Mantua los que poblarla consiguieron;

y los romanos que la amplificaron

por sus osos Ursaria la dijeron;

los que su fuerte muro acrecentaron

nombre de Mayorito le añadieron:

de aquí Madrid se intituló; de modo,

que por mayor se viene a alzar con todo.

San Anastasio predicar dispuso

el evangelio en su región nombrada;

y la imagen san Pedro apóstol puso

de la virgen de Atocha frecuentada;

cuando la insignia del Dragón depuso,

la del persa tomó con estrellada

orla; obispal obedeció al romano,

sin mitra al godo, y luego al mahometano.

De Gracíán Ramírez restaurada

líbico otra vez tuvo cautiverio:

del segundo Ramiro conquistada,

quedó algún tiempo en el leonés imperio;

ganola al moro con sangrienta espada

el sexto Alonso, emperador hisperio;

después don Juan primero de Castilla,

a un rey de Armenia presentó esta Villa.

No se apartó del trono castellano

por su lealtad, y lecho saludable

de Carlos quinto, César del germano,

reedificó su Alcázar agradable:

cogiendo su hijo el cetro lusitano,

la amplificó a los belgas formidable;

con la paz la ilustró el tercer Felipe;

y el cuarto con las ninfas de Aganipe.

Obtiene en Cortes voto, voz y asiento

franca feria, magnánimos señores,

de príncipes vistoso lucimiento,

pomposa ostentación de embajadores,

del pontificio Nuncio el ornamento,

corregidor, tenientes, regidores,

reales consejos, muchos pretendientes,

palestras y academias diferentes. con un idioma bárbaro, con un incesante canje comercial, de papeles por cosas» (Marruz 175). Seis años después, cuando escribe esta crónica, el cuadro social con el que se encuentra no sólo no ha cambiado, sino que ha acelerado y profundizado el mercantilismo en las relaciones sociales.

En las crónicas martianas prima lo que hoy se califica como lenguaje poético, lenguaje que, al decir de Rotker, «resplandece aunque la selección temática y la construcción textual dependan de las jerarquías establecidas por la actualidad y por la referencialidad. Resplandece, aunque las frases se hayan escrito con la premura del periodismo y la supuesta impureza de un trabajo asalariada y dirigido a un lector masivo.» (201).

De entre los múltiples ejemplos de poetización de lo real que se visibilizan en esta crónica uno es sobresaliente. Se trata de la connotación contrapuesta que se le da a la luz, ligada a la razón y a la moral, y a la oscuridad, relacionada con la irracionalidad y el odio. De modo enfático Martí declara: «iparece a veces que hay cierta fuerza moral en los rayos del sol!» (445). Y esa iluminación que viene de la naturaleza, idealizada y sublime, no es valorada por los trabajadores que «quieren que las horas de trabajo no sean más que ocho, no tanto para que pueda entrar alguna luz por el alma en las horas de reposo, como para que se vean obligados los fabricantes a emplear a los obreros que hoy no tienen faena» (447). Las palabras oscuras de los líderes obreros a sus seguidores los distancian de la sensibilidad y la claridad espiritual asociada a la luz. En Nueva York, dice Martí, hubo «discursos más encendidos que las antorchas que iluminaban a los oradores, y más negros que su humo» (446). Las palabras son acordes con «su oscuro entender» (451) y con «la negrura de las minas hondas» (446), lugar en el que simbólicamente se ubican.

"El proceso de los siete anarquistas", la segunda crónica de nuestro análisis, relata el proceso judicial de los siete anarquistas que arrojaron, en la huelga de la primavera en Chicago, una bomba que mató a cinco policías. El texto recuerda el 
obrera ni a postular que el estado de cosas dado en términos sociales y económicos es en Estados Unidos justo o igualitario. Contrario a ello, el cubano revela la antítesis y la asimetría que se produce entre la fortuna de unos pocos y la pobreza de muchos. Se ha visto, dice, que los obreros que se levantaron con la petición de la reducción de horas de trabajo carcomen, con «cordura de locos, los descansos de la fábrica desequilibrada, fábrica de mármol sobre lodo, en que ocupados en la busca de oro viven hoy los hombres» (446). El cuestionamiento al razonamiento obrero, que el oxímoron pone en juego, no afecta el reconocimiento de la justicia de sus demandas. El mármol de la fábrica, su riqueza, se asienta sobre el lodo que constituye la miseria del trabajador: éste es su desequilibrio, el mismo que se señala nuevamente unas páginas más adelante cuando se enuncia que, así como la sociedad en general se opone a los métodos violentos de negociación utilizado por los obreros, la sociedad toda «acepta la revisión del sistema social de ahora, y va pensando en la manera de ir poniendo un poco del mármol que sobra en unas calles, en el lodo que sobra en otras.» (447-48).

Ahora bien, si el mármol aparece en el texto de Martí como símbolo de la riqueza de los propietarios burgueses, el oro al que una de las citas anteriores hace referencia se asocia de un modo extendido y general al prominente ímpetu lucrativo de la sociedad americana toda. El cubano desnaturaliza el materialismo predominante en las ciudades estadounidenses en gran parte porque desde su propia experiencia no era una conducta ni un paradigma social predominante. Debe recordarse que, tal como observa Fina Marruz, el cubano llega a Nueva York «(v)enido de la atmósfera estancada española, entre la indolencia indígena y la del patriciado criollo» (175). Su modelo de organización social se lo brindan las viejas ciudades europeas, distantes todavía del vertiginoso crecimiento urbanístico e industrial de Estados Unidos y de los esfuerzos individuales movilizados por la propiedad privada y el lucro. En enero de 1880 Martí llegó a Nueva York y se encontró «con gentes que no parecían perseguir con su actividad fin ulterior alguno,
En pedernales duros se levanta,

de ellos la luz sacando esclarecida

con que su silla a muchas se adelanta,

de famosos monarcas erigida

admira docta, militar espanta,

llena de erudición, patria florida

de obispos, capitanes, escritores,

con dos Papas, y cuatro emperadores.

Hermosas calles cuatrocientas tiene,

plazas catorce, en ellas señalada

la Mayor, por su trato tan solemne,

como por sus balcones celebrada:

casas catorce mil también contiene

de diez y ocho parroquias adornada

veinte y dos hospitales opulentos,

y sesenta riquísimos conventos.

Cinco palacios a la real persona

dirige en su región de Flora el giro:

uno el Alcázar, de Madrid corona;

otro junto a su cerca el Buen Retiro;

sigue el del Campo, albergue de Pomona;

en bosque fértil el del Pardo admiro;

el quinto es Aranjuez, donde se ostenta

del Elisio dosel, del Tempe afrenta.

Compendio de estas fábricas vistoso admira el Escorial, templo jocundo

por su artificio tan maravilloso

como por su recreo sin segundo

al más de España mártir valeroso,

lo dedicó el más cuerdo rey del mundo,

de jerónimos ricos gran convento,

de altos monarcas raro monumento.

También ciñe Madrid pueblos no iguales,

y el gran Felipe la hizo más perita,

adornando de estudios generales

el Colegio Imperial del jesuita.

Negándole con ímpetus marciales

el portugués, al castellano incita

aclamando otro rey no menos fuerte,

más fiado con la espada que en la suerte. 
Fieras lides entre una y otra gente formó el de Venus riguroso amante, hasta dar por el anglo a la valiente Castilla Portugal la paz triunfante;

Pedro, hoy del Luso príncipe regente; a Lisboa sublima vigilante;

y en Madrid resplandece soberano

Carlos segundo, rey del Castellano.

En la Nueva Castilla, Talavera

de la Reina recibe gran corona,

Calatrava fructífera y guerrera;

Vélez, Pastrana, Illescas y Escalona;

Zafra, Alcántara en célebre ribera

honor de Extremadura y de Belona,

donde no menos Medellín campea,

Feria, Béjar, Montijo y Zalamea.

[II]

Viderat Hadriacis Venetan Neptunus in unde Stare Urbem, \& toto ponere jura mari:

Nunc mihi Tarpejas quantumvis Iupiter arces Objice \& illa tui moenia Martis, ait:

Si pelago Tibrim praefers, urbem adspice utram

Illam homines dices hanc posuisse Deos.

\section{ELOGIO III}

Vio Neptuno a Venecia casta Aurora sobre el golfo adriático fundada,

y con imperio grande y fuerte espada mandar al mar que ambiente la enamora.

Entonces dijo a Júpiter: «Ahora aunque me opongas a Tarpeya osada con su fuerza de Marte celebrada, ha de salir la mía vencedora.

Si al Tíber el gran piélago prefieres, ve una y otra ciudad que triunfa, y doma y cómo lo marcial y docto precia,

para que más atento consideres que de los hombres es compuesta Roma, y de los dioses fundación Venecia». bebe allí todo «cuanto le supo a vino» (455), luego caen sobre una cervecería, para seguir bebiendo «(e)n las gorras y en el hueco de las manos» (455). Todo esto para después escapar mientras «los policías venían de otro encuentro, muchos de ellos manchados de sangre» (455). Se enfrentan los cuerpos del desenfreno contra los cuerpos del deber que, a diferencia de los obreros, se comportan de un modo uniforme en bloque. «iY en la noche de la bomba mortal, ni uno solo se hizo atrás, ni huyó la muerte!» (455) expresa enfáticamente Martí.

Además de los obreros moderados y radicalizados, además de la policía y los fabricantes, "Grandes motines obreros" describe a la sociedad americana en general como un actor colectivo siempre contrario a las revueltas obreras. Martí señala que «opinión, gobierno, prensa, clero ¡qué! el trabajo mismo, se levantan contra las turbas de fanáticos que, en vez de emplear su fuerza en rehacer las leyes, fortalecen y justifican las leyes actuales con el espanto que inspiran sus crímenes» (449). La enumeración de diferentes sectores sociales e instituciones muestra la extendida desaprobación pública respecto de los hechos de violencia que protagonizan los obreros en las huelgas y en los enfrentamientos armados con la policía. «Ni la policía, ni los jueces, ni el gran jurado, que es la opinión general, perdona a los que han ensangrentado a Chicago, ni a los que los imitan» (449) enuncia Martí, y continúa diciendo «no ha habido una muestra de simpatía por los anarquistas presos» (449). Lo que el cronista reitera a través de la enumeración es la diversidad de grupos sociales confrontados con los huelguistas, grupos sociales a los que se les adjudica capacidades legislativas y punitivas hegemónicas y oficiales. La cita generaliza la reprobación y la condena social legitimada por la representatividad del gran jurado, cuya valoración como mecanismo de justicia se resalta en "El proceso de los siete anarquistas" y se mitiga y cuestiona en "Un drama terrible".

Si bien el cronista rechaza explícitamente la violencia de los métodos de los trabajadores e incluso desestima e impugna sus sistemas ideológicos, en el caso de los anarquistas particularmente, esto no lo lleva a negar la validez de la demanda 
«seguramente favorable entre los lectores argentinos del 80, a quienes estaba destinada la nota que se publicó en La Nación» (248).

Esta desvalorización ideológica y física de los obreros que promueven las huelgas y los mítines es altamente visible en las animalizaciones de las que son objeto. «Ese odio a todo lo encumbrado, cuando no es la locura del dolor, es la rabia de las bestias» (451), sentencia Martí valorando y deshumanizando la cólera de un sector de los trabajadores que están produciendo en «todo el país, aun en la gente de alma apostólica, una conmoción semejante, a la que produce en una calle pacifica la aparición de un perro atacado de hidrofobia» (450). Visto como un animal, como un animal enfermo y peligroso, el movimiento activo de los trabajadores se aquieta luego de que las fábricas ofrecen distintas respuestas al conflicto laboral. El último párrafo, que opera como conclusión evaluativa, repite la imagen de los obreros como animales peligrosos. Allí Martí dice:

Es general esta tendencia al arbitramiento general, la atención al gran problema, la fe en la sensatez pública, y como cierto legítimo orgullo, que ya se nota, de ver como el aire de la libertad tiene una enérgica virtud que mata a las serpientes (456)

Lo que las animalizaciones muestran es que, tal como afirma Fina Marruz, en su prosa norteamericana, Martí hace «que sean las imágenes mismas las que hablen: piensa con imágenes» (179). Y en el movimiento de pensar con imágenes, las relaciona, las superpone, las agrupa y las confronta. Esto último es lo que sucede frecuentemente alrededor de la imagen principal de los obreros radicalizados a la que se oponen la de los otros obreros moderados, la de los dueños de las fábricas, la de la policía y la de la sociedad en general.

La policía se presenta como un grupo de personajes épicos, cuya valentía es explícita y reiteradamente señalada. Su heroísmo se acentúa mediante el contraste de conductas, cuyo ejemplo más claro hallamos en la anécdota de los emborrachamientos de un grupo de huelguistas que luego de realizar una serie de fechorías huye del encuentro con la policía. La turba ataca, primero, una farmacia y
[III]

Aun no permite la temida Roma, que la exceda la invicta Venecia.

\section{ELOGIO V}

Competencias terrestres y marina traen las gentes venetas y romanas: Roma del dios guerrero iras humanas, Venecia de Antenor fuerzas divinas.

Una el robo logró de las sabinas, otra el de las doncellas nerentanas; cual, contra las violencias africanas, y cual, contra las Galias sus vecinas.

Libre aquella de rey se hizo famosa; tribuna esta y después ducal se aclara: una asombro imperial, otra imperiosa.

Siempre fuertes las dos; hoy, con fe rara Venecia patriarcal y valerosa; y la triunfante Roma con tïara.

\section{[IV]}

Descríbese así misma la suntuosa ciudad de Génova.

\section{ELOGIO XII}

Génova soy, de muros defendida, de mi fundador Jano así llamada, en sitio desigual fortificada, de Liguria metrópolis florida

Termino a Italia, domo al mar temida, de inauditos varones ilustrada, y ahuyento fuerte de valor armada las armas que procuran mi caída. Solamente recibo al que me alienta llevará quien me enoja atroz espanto, porque eternizo mi blasón sangrienta.

Brillo en el mundo con esfuerzo tanto que fuera aun más poblada y opulenta, a no ser mi discordia mi quebranto. 
A la heroica y famosa ciudad de Ferrara

\section{ELOGIO XII}

Por derecho a Ferrara pertenece del marcial hierro el nombre esclarecido de las feroces armas conseguido con que auxiliar Belona la engrandece. Al paso que famosa resplandece con los grandes trofeos que ha tenido, el acero de rojo humor teñido envaina por la paz la que enriquece.

Su duque Alfonso, noble y generoso trajo del cielo la feliz justicia que suspende su orgullo belicoso.

Con la magnificencia que propicia su intrépida inquietud vuelve en reposo y en científico lustre su milicia.

\section{[VI]}

A la opulentísima ciudad de Ámsterdam competidora de la Corte veneta.

\section{ELOGIO XIV}

Pescador Glauco un tiempo, hoy espumosa deidad ve de Ámsterdam los triunfos graves, antes con redes, y después con naves, reina del mar, de la justicia diosa. Bésale el dios cerúleo como a esposa, de su palacio dándole las llaves, porque en el agua, y viento, peces, y aves sus Argos, guarden su corona undosa.

Venecia celos toma, en la opulencia que al mar su esposo flechas tira y balas ésta de Amor, y aquélla de prudencia.

Porque para volar más con sus alas, siguen en valerosa competencia Venecia à Venus, y Ámsterdam a Palas.
Opuestos a las distintas capas sociales, cuyas actuaciones se justifican, los obreros radicalizados son cuestionados, además de por la violencia de sus actos, por la indeterminación y la diversidad de sus métodos. Ellos han hecho estallar «una fuerza que es acaso demasiado vasta y heterogénea, para que pueda echar toda por igual camino» (445) advierte Martí al respecto, para luego criticar a los anarquistas que integran este movimiento y «que no quieren ley, ni saben qué quieren (...) con un desorden de medios y una confusión tal de fines que les priva de aquella consideración y respeto que son de justicia para toda especie de doctrinas de buena fe encaminadas al mejor servicio del hombre» (452). Rechazados ideológicamente, los inmigrantes anarquistas y también los socialistas serán desvalorados estéticamente. De ellos se ofrecen prosopografías connotadas que tienden a constituirse en retratos morales.

«Esos trabajadores, en su mayor parte alemanes, se trajeron esa terquedad rubia, esa cabeza cuadrada, esa barba hirsuta y revuelta que no orea el aire y en que las ideas se empastan» (452) señala Martí. La fisonomía, de este modo, es leída como signo de idiosincrasia. Desde esta perspectiva se señala, por ejemplo, que Schwab tenía «pelo y barba al descuido» (453) y Most «una lengua grandaza como su barba» (452), con lo que el desarreglo en la barba y en el pelo se corresponde con sus propias ideas a la vez que éstas son proyectadas en el plano físico.

El lugar de procedencia de los huelguistas en particular, y de los inmigrantes afincados en Estados Unidos en general, es planteado como un hecho determinante y definitorio de su conducta social. Martí aconseja «a los pueblos que se acrecen con la inmigración de Europa ver en qué ayuda y en qué daña la gente que inmigra, y de qué países va buena, y de cuál va mala» (451). Al maniqueísmo en que cae su planteamiento se le suma también una nota de xenofobia al referirse al peligro que corre Estados Unidos «de inyectarse en las venas toda esa sangre envenenada» (452) de la inmigración perniciosa. Según María Minellono, el eco de estas ideas habrá sido 
Los trabajadores radicalizados se presentan como antagonistas de la paz social, promotores de una virulenta violencia material y simbólica que se repudia explícitamente. Martí es frecuentemente enfático en sus desvaloraciones al respeto. Por ejemplo, luego de describir el arsenal y la bibliografía encontrado por la policía en distintos lugares de los anarquistas concluye «¡Al más noble de espíritu, da arrebatos de ira esta perversión de la naturaleza humana!» (450).

Estos trabajadores venidos de la Europa oriental representan la fuerza destructiva de un orden social que Martí aprueba. ¿Cómo, en medio de las manifestaciones obreras, no iba a estar la policía rodeando las plazas y pronta a la carga si "todo el Este de la ciudad está sembrado de logias de socialistas alemanes, que van a beber su cerveza, y a juntar sus iras acompañados de sus mujeres propias y sus hijos, que llevan en sus caras terrosas y en sus manos flacas las marcas del afán y la hora de odio en que han sido engendrados?" (446), se pregunta el cubano, justificando, por un lado, la vigilancia policial, y, por otro lado, interpretando el odio como marca social e histórica del propio nacimiento de estos obreros inmigrantes.

«(N)o tiene la capacidad de gobernar con justicia: y no debe gobernar el que no tiene la capacidad de convencer» (448-49) sentencia el cronista, luego de haber ofrecido sobrados ejemplos de la incapacidad de los huelguistas para persuadir sobre la validez de sus reclamos no sólo a la elite dirigente sino a la sociedad en general. Al propio Martí no lo convencen las estrategias de lucha y el modo en que los trabajadores reclaman que su jornada laboral se reduzca a ocho horas diarias. «(E)s su derecho quererlo, y es justo; pero no es su derecho impedir que los que se ofrecen a trabajar en su lugar, trabajen» (453), considera el cronista que, a través de la construcción adversativa, contrapone la legitimidad de la demanda con la ilegitimidad de coartar la libertad de trabajo. Enfrentados con sus otros compañeros obreros, los huelguistas serán contrapuestos también con los fabricantes que cierran sus talleres «porque no pueden continuar produciendo con esta época de precios bajos, en condiciones que requerirían más gastos de producción» (453).
[VII]

A la competencia de las excelsas Cortes de Madrid y París.

\section{ELOGIO XV}

Dando a Minerva asombro y a Belona, contienden regias en feliz campaña, Madrid cabeza y corazón de España, París de Francia espléndida corona: cual, ser de Manto fundación blasona, y cual, de Luco: aquella se acompaña con leones, con cuanto delfín baña ésta, borrascas bélicas pregona.

Con pares una tener par no admite, con grandes otra alcanza lo que quiere, cada cual de las ciencias firme polo.

Su competencia a jueces se remite,

y así tener en su favor adquiere a Júpiter París, Madrid a Apolo.

\section{[VIII]}

A la muy noble y leal ciudad de Montilla.

\section{ELOGIO XVI}

Mi gran patria Montilla, verde estrella del cielo Cordobés, agradó a Marte, con las bellezas de la diosa Astarte del fuego militar áurea centella.

San Francisco Solano es hijo de ella, padre el Magno Pompeyo, lustre el arte, por Baco y Ceres, del Elisio parte, y por Felipe el Grande ciudad bella.

Corte es de los famosos descendientes del Alonso que en una del sol cumbre murió matando mahometanas gentes, Da con su fama al moro pesadumbre, de hojas marciales, y astros elocuentes sombra a las deas, $\mathrm{y}$ a las musas lumbre. 
Paz entre Inglaterra y Holanda

\section{ELOGIO XVIII}

Sube al Parnaso el hijo de Ericina, y ve admirado la contienda extraña, de Londres, corte regia de Bretaña, y de Holanda Ámsterdam menfis marina. Con poderosa armada una domina el soberbio raudal que sus pies baña, otra con beldad recta, y naval saña, la infernal lid transforma en paz divina. Ambas dan nuevas alas al flechero infante, con la pluma que aprovecha mejor en la batalla que el acero.

Las propias armas el Amor deshecha, porque hiere mejor al Dios guerrero, arco Ámsterdam de Amor, y Londres flecha.

Ciudad por ciudad, Lisboa en Portugal

\section{ELOGIO XIX}

Los solios del adusto americano la opulenta Pekín, trono del chino Samarcarda, Sol del Tártaro ferino, Ispahan del persa; Agra del mogolano.

Petra de Arabia; Menfis del gitano, la ciudad de Nembrot, y la de Nino, la que reedificó el Magno Constantino, el dosel de Polonia, el sueco, el Dano.

Ámsterdam; la alta Moscú; Prezcop, silla del Gran Can, las metrópolis de Italia,

Viena, y Madrid, de Austria, y de Castilla

De Albión Londres, y París de Galia

no igualan a Lisboa, lusa Corte,

campo de Apolo, y templo de Mavorte. dirige a su amigo Manuel A. Mercado en 1886, el mismo año en que se publica la crónica que venimos comentando. ${ }^{2}$ Allí dice:

Bueno, pues: todo me ata a New York: las consecuencias de los errores políticos de nuestro país; - la cercanía a esa tierra mía, que no sabe de mí, y por la que muero (....). A otras tierras, ya sabe usted por qué no pienso ir. Mercado literario, aún no hay en ellas, ni tiene por qué haberlo. En el mercado político yo no me he de poner. En el mercado judicial, los buenos abogados sobran (...). Pero mis instrumentos de trabajo que son $\mathrm{m}$ lengua y mi pluma, o habrían de quedarse en el mismo encogimiento en que están aquí, o habrían de usarse en pro o en contra de asuntos locales en que no tengo derecho ni voluntad de entrar, y en los que sin embargo, como ya me sucedió en Guatemala y en Venezuela, ni el silencio me es permitido (Martí, Cartas a Manuel A. Mercado). ${ }^{3}$

Dos libertades le permite Estados Unidos, particularmente Nueva York, a Martí: una es la libertad de expresión que le está vedada en otros países que, como él mismo dice, no le consienten ni su silencio; la otra es la libertad económica que le permite la existencia de un mercado literario separado de las instituciones del Estado, separación que, propugnada por el cubano, sólo era posible en una ciudad como Nueva York, que «con el mismo movimiento que genera una «crisis», una «alienación» o un «exilio», es la condición de posibilidad de la autonomía del intelectual de las instituciones tradicionales; autonomía que para el intelectual moderno, en contraste al letrado o escritor «civil», era indispensable» (73-4).

El contexto biográfico e histórico en que Martí escribe esta crónica no puede desestimarse puesto que éste coadyuva a la significación que, en este escrito, adquiere el tema de la libertad, cuya valoración y exaltación no surge exclusivamente como un modo de defensa ante la supuesta incapacidad de los huelguistas para comprenderla y adecuarse a sus reglas, sino también de los datos y percepciones que le brindan al cubano sus experiencias personales y profesionales.

Esta epístola de Martí tiene una gran importancia a la hora de comprender la permanencia del escritor en Nueva York porque amplía la explicación de su larga estadía en Norteamérica considerada sólo en relación con su activismo político y su trabajo en las comunidades de emigrantes que serán la base del Partido Revolucionario Cubano fundado en 1892. Cfr. Ramos, Julio, Desencuentros de la modernidad en América Latina. Literatura y política en el siglo XIX, México, FCE, 2003, p. 73.

${ }^{3}$ La carta es del 22 de abril de 1886. La trascribimos de Ramos, Julio, op. cit., p. 73. 
de carencia que provienen de espacios sociales de carencia. Así, Martí llega a sostener que:

En Alemania, bien se comprende, la ira secular, privada de válvulas, estalla. Allá no tiene el trabajador el voto franco, la prensa libre, la mano en el pavés, allá no elige el trabajador, como elige acá, al diputado, al senador, al juez, al Presidente: allá no tiene leyes por donde ir, y salta sobre las que le cierran el camino: allí la violencia es justa, porque no se permite la justicia (451).

Privada de estados democráticos que, mediante el voto popular, legitimen las autoridades gubernamentales, la legislación y la justicia social, Europa, el "allá" de la enunciación, es confrontada con Estados Unidos, el "acá" desde donde se pronuncia Martí, que se instituye como ejemplo positivo de organización social. Luego de preguntarse si la libertad mejora los destinos de los hombres sin violencia, Martí se responde: «(p)arece que sí: parece que el ejercicio de sí mismos, acá donde es perfecto, ha enseñado a los hombres la manera de rehacer el mundo, sin amenazarlo con su sangre» (447). La respuesta idealiza, de un modo hiperbólico, a la sociedad americana e interpreta su individualismo como motor del aprendizaje de la convivencia.

El punto principal que la crónica postula como diferencia entre el "acá" norteamericano y el "allá" europeo se halla en el reconocimiento de las libertades cívicas individuales que, en estos lugares, se respetan y desconocen respectivamente. La libertad es un valor supremo para Martí que llega a afirmar, en un registro aforístico, que «(d)os cosas hay que son gloriosas: el sol en el cielo, y la libertad en la tierra» (447). Las circunstancias de la enunciación de este texto enriquecen y completan la significación y la importancia que el cronista le adjudica a la libertad que experimenta en Estados Unidos, país en el que vive, exiliado, una larga estadía que va desde 1880 a 1895. Dichas circunstancias son sintetizadas en una carta que le

\section{NARRAR EL PROBLEMA OBRERO: PERMANENCIAS Y RUPTURAS EN TRES} CRÓNICAS MARTIANAS

\author{
LUCIANA ANDREA MELLADO \\ Universidad Nacional de la Patagonia "San Juan Bosco" \\ Comodoro Rivadavia, Argentina
}

\section{INTRODUCCIÓN}

Las crónicas periodísticas constituyen una extensa zona de la producción textual de José Martí. A pesar de que la historia literaria centró su interés de un modo casi exclusivo en sus poesías, más de la mitad de la obra escrita por el cubano está compuesta por textos publicados en los periódicos, ${ }^{1}$ textos donde convergen el

\footnotetext{
"Recibido: 29-01-2008 Aceptado: 14-03-2008

1 Esta focalización de la crítica en la obra poética martiana responde a una operación selectiva e interpretativa. Selectiva porque canoniza una determinada escritura y un determinado género en
} 
discurso periodístico y el literario a través de un lenguaje que sirve a la circulación de un sentido informativo y coyuntural, a la vez que deja de ser literal e instrumental para adquirir un peso y una densidad estéticos que trascienden los límites de la mimesis y la referencia.

Este trabajo examina tres crónicas martianas, "Grandes motines obreros", “E proceso de los siete anarquistas" y "Un drama terrible", con el propósito de analizar las continuidades y rupturas discursivas más significativas que entre ellas existen en la representación del conflicto laboral y social suscitado en Estados Unidos a partir de los mítines y huelgas producidas en mayo de 1886. Los textos fueron publicados en La Nación de Buenos Aires los días 2 de julio y 21 de octubre de 1886, y 1 de enero de 1888, respectivamente. Pertenecen a las Escenas norteamericanas, una serie de crónicas sobre la vida norteamericana que José Martí escribió durante su exilio en Estados Unidos para numerosos periódicos latinoamericanos, entre ellos La Nación de Buenos Aires, El Partido Liberal de México y La Opinión Nacional de Caracas.

Las tres crónicas seleccionadas elaboran narrativamente un mismo tema: el problema obrero en Estados Unidos, pero en conjunto muestran el desarrollo y el cambio del pensamiento y del discurso martiano que resemantiza en el último texto muchos de los significados desplegados en los dos primeros, en los que es explícito el rechazo a la violencia que los obreros manifiestan en dichas huelgas. Este rechazo inicial va a la par de la confianza en el sistema republicano y en su sistema de derechos que, en la última crónica, va a revisarse y cuestionarse, haciendo visible un viraje en su discurso político y social que comienza a visibilizar la ineficacia de la vía electoral para las clases populares, la complicidad del estado, la Iglesia y los capitalistas en el sojuzgamiento y la explotación de las clases subalternas.

menoscabo de una extensa zona de la producción textual del mismo autor. Interpretativa porque se adecua a un modo de entender y dicotomizar lo artístico y lo extra-artístico, lo literario y lo extraliterario, confinando las crónicas periodísticas a los segundos términos enunciados. Ver, al respecto, Rotker, Susana. La invención de la crónica, Buenos Aires, Ediciones Letra Buena, 1992, p. 15 y ss.

\section{Desarrollo}

"Grandes motines obreros" narra las huelgas y otras acciones de lucha que, en Estados Unidos, realizan los trabajadores para la reducción de la jornada laboral a ocho horas. Los sujetos sociales que la crónica refiere y describe tienden a organizarse en dicotomías antitéticas: de un lado, se encuentra la sociedad americana en su conjunto y el propio enunciador, a quienes se presenta con espíritu moderador ante el conflicto obrero, y, por el otro lado, se hallan los trabajadores anarquistas y socialistas, a quienes se muestra con un ánimo de confrontación radical. Si bien la referencia a los actores se mantiene a lo largo de las tres crónicas que repiten y comparten su repertorio actancial, no es constante ni invariable, como veremos más adelante, el modo en que se construyen dichas referencias.

El mundo de los obreros aparece en "Grandes motines obreros" dividido en dos grupos antagónicos: por un lado, los violentos; por el otro, los moderados. La pertenencia a la clase obrera se fragmenta por el método de negociación con las clases más altas, fragmentación asociada de modo directo y determinante a la nación de origen. A pesar de que, tal como admite Martí, «entre los que azuzan desde las tribunas a los trabajadores la noche de la reunión, no hay solo alemanes, no, sino patriarcas americanos, hombres de buena fe y habla profética» (446), el grupo rechazado está conformado por anarquistas y socialistas que llegan a Estados Unidos de «la Europa iracunda» (448).

«Esos alemanes, esos polacos, esos húngaros», dice Martí, «no traían, al venir a esta tierra (...) aquella costumbre y fe en la libertad, aquel augusto señorío, aquella confianza de legislador que pervade y fortalece al ciudadano de las repúblicas» (452). El distanciamiento que el cronista toma respecto de los inmigrantes descritos se evidencia en el pronombre demostrativo plural que se reitera en la enumeración. Lejos de ellos, los concibe alejados de las normas republicanas con las que él acuerda. Los inmigrantes que protagonizan y promueven las huelgas se constituyen en sujetos 
experimentó con diversos temas y materiales que incorporó y adaptó a su trabajo creativo.

La relación de Varo con el movimiento surrealista fue de enorme importancia para ella como pintora. En un momento crucial de su desarrollo artístico, cuando estaba buscando una orientación para sus técnicas, adquiridas tan laboriosamente, el surrealismo le estimuló su tendencia hacia lo imaginativo y la incitó a adoptar una actitud de búsqueda, de experimentación y de ironía. ${ }^{14}$

Entre las creaciones plásticas de Varo, correspondientes a estos años, se puede apreciar el uso de diversas técnicas como la tinta, la acuarela, el pastel, la parafina y el óleo; con estas obras participó en varias exposiciones colectivas tales como la Exposición Internacional del Surrealismo en Tokio (1937), en la galería de Bellas Artes en París (1938), en la Galería Robert en Ámsterdam (1938) y en México, en la Galería de Arte Mexicano (1940). Estos años en París fueron de intensa actividad creadora. ${ }^{15}$ Sin embargo, esta situación pronto se vio interrumpida. En julio de 1940, los nazis ocuparon París, ${ }^{16}$ lo que obligó a Varo a instalarse en Canet-Plage en un albergue organizado por otro surrealista, Jacques Hérold ${ }^{17}$. En julio del mismo año se refugió temporalmente en la Villa Air-Bel en Marsella, a la espera de poder arreglar su viaje hacia tierras americanas. Un año más tarde, el 20 de noviembre de 1941, en compañía de Benjamin Péret, partieron de Casablanca rumbo a México. ${ }^{18}$ Las circunstancias e implicaciones de este viaje pueden seguirse a través de una carta escrita por Varo, fechada en 1946, dirigida a sus amigas, las hermanas Martín Retortillo, compañeras de la niñez que radicaban en Madrid, a quienes les comenta:

${ }_{13}^{13}$ Leonora Carrington (Inglaterra 1917). Pintora y escritora. Actualmente radica en la ciudad de México. «She studied in England, Florence and Paris before meeting Max Ernst in London in 1937, moving with him to Paris, then to St. Martin D'Ardèche», ibidem, p. 287.

${ }^{14}$ J. Kaplan, Viajes inesperados..., op. cit., p. 69

${ }^{15}$ En el Catálogo editado por W. Gruen, y R. Ovalle, Remedios Varo. Catálogo razonado, México, Era 1998, se incluyen las principales obras de esta época.

${ }^{16}$ El capítulo «Entre los surrealistas. París y Marsella» presenta ampliamente de esta época de la vida de Varo; J. Kaplan, Viajes inesperados..., op. cit., pp. 55-83.

${ }_{17}^{17}$ Jacques Hérold, pintor surrealista (Rumania 1920-París 1987)

18 Para más detalles, véase el artículo que se ocupa del relato de este viaje en E. Mendoza Bolio, y J. Farré Vidal, «Pies en polvorosa. Travesía hacia México de Remedios Varo»; B. López y J. Farré (eds.), Viajes y viajeros, México, Instituto Tecnológico y de Estudios Superiores de Monterrey, 2006, pp. 209224 medios y hombres nacidos en países cuya organización despótica da mayor gravedad y color distinto a los mismos males que aquí los hábitos de libertad hacen llevaderos» (58). Sujetos de distintos órdenes culturales, económicos y jurídicos, los obreros estadounidenses se ubican, a pesar de los problemas que los afectan, en un paisaje social civilizado, y los obreros inmigrantes de la Europa oriental se sitúan en la barbarie, planteada como un espacio simbólico de origen y de pertenencia.

La barbarie es el lugar de la carencia: no tiene palabra, ni voto, ni leyes. La civilización sí: es el lugar del derecho que, en la crónica, presupone la justicia social. Significativo es al respecto que Martí señale que en Estados Unidos hasta «el más infeliz tiene en la boca la palabra libre que denuncia la maldad, y en la mano el voto que hace la ley que ha de volcarla» (56). La libertad ciudadana norteamericana tiende a igualar los derechos de sus trabajadores mientras que el llamado de los anarquistas tiende a dividir el movimiento obrero. Quienes se reúnen para el sacudimiento público son «los fanáticos, los destructores y los charlatanes» (58), en todo contrarios a la moderación y a la cordura de los obreros no politizados.

Los procedimientos antitéticos que separan la Europa violenta y bárbara de la América civilizada y democrática, y que oponen a los distintos grupos de obreros, son expansivos en esta crónica en la que tiende a dicotomizarse a toda la sociedad en general. Para el cubano «(a)ndan por la vida las dos fuerzas, lo mismo en el seno de los hombres que en el de la atmósfera y en el de la tierra. Unos están empeñados en edificar y levantar: otros nacen para abatir y destruir» (57). El antagonismo de los grupos sociales que las huelgas y los enfrentamientos armados exteriorizan responde, entonces, no sólo a divergencias ideológicas y socio-económicas, sino también a disyuntivos despliegues de la espiritualidad humana que se visibilizan durante el conflicto obrero.

«(T)odas las grandes ideas de reforma se condensan en apóstoles y se petrifican en crímenes, según en su llameante curso prendan en almas de amor o en 
almas destructivas» (57), sentencia Martí. Sus palabras, en las que se superponen y convergen términos bíblicos con términos legales, ejemplifican cómo el discurso martiano «opera con fragmentos de códigos tradicionales, que sin embargo no implican su organicidad respecto a esas tradiciones» (Ramos 76-7). El maniqueísmo que la anterior expresión pone en juego revela más que una operación de pensamiento, una operación enunciativa que, junto con las antítesis, profundiza discursivamente la división ya delineada en la crónica anterior del movimiento obrero.

Los «trabajadores cultos» (58) no comprenden ni apoyan a los «ignorantes» (58), cuyo accionar violento Martí condena, al igual que en "Grandes motines obreros", en consonancia con el rechazo público. Cuando los diarios dieron a conocer el veredicto del jurado, la condena a la horca de los siete anarquistas, «no se oía una sola protesta entre los que se acercaban ansiosamente a leer la noticia» (57), cuenta el cronista, que agrega unos párrafos más adelante que «ni el curioso indiferente que se acercara hoy a las tablillas de los diarios hubiera podido oír a un solo trabajador ni comerciante, ni una palabra de condenación o de ira contra el acuerdo del jurado» (58). Los ejemplos antedichos muestran, además del repudio social a los condenados cómo la prensa escrita funciona como un espacio de articulación de lo público con el público.

Martí relata cómo «se vio salir del tribunal, como si fuera montado en un relámpago, al cronista de un diario, - el primero de todos. Volaba. Pedía por merced que no lo detuviesen. Saltó al carruaje que lo estaba esperando» (61). La escena marca a través de la actuación del reporter la relevancia que ya adopta en la prensa estadounidense la premura y el valor de la primicia noticiosa, además del interés informativo. A esta misma idea abona el pasaje que relata cómo luego de conocer la sentencia, a la mulata de Parsons «(l)os noticieros de los diarios se le acercan, más para tener qué decir que para consolarla» (61). El periodismo, que en "Grandes motines obreros" aludía principalmente a la «prensa libre» (451) ponderada como un
Hasta este momento es evidente que Varo, desde Barcelona, deseaba involucrarse con el movimiento parisino. En el mes de octubre de 1936 Varo conoció, por la intervención de Oscar Domínguez ${ }^{7}$, al poeta y narrador Benjamin Péret, integrante del grupo surrealista francés y uno de los amigos más cercanos de André Breton. Péret había llegado a Barcelona, en agosto de ese año, como activista político; a partir de entonces, Varo y Péret iniciaron un «asunto amoroso», como él mismo lo comenta en una carta dirigida a Breton: «Estoy metido en un asunto amoroso que me retiene aquí hasta que la joven pueda acompañarme a París, así que nada puedo decir de mi vuelta». ${ }^{8}$

En la primavera de 1937, la inseguridad y violencia generadas en España por la guerra civil, obligaron a Varo a huir para refugiarse en París y con ello iniciaría, sin ella imaginarlo siquiera, su vida como exiliada. ${ }^{9}$ En París entabló amistad con artistas de la vanguardia como Víctor Brauner, ${ }^{10}$ Wolfgang Paalen,11 entre otros; también conoció a Max Ernst ${ }^{12}$ y a Leonora Carrington. ${ }^{13}$ Durante esta época, Varo

Masanat, Maruja Mallo, Angel Planells, Jaume Sants, Nàdia Sokalova y Joan Ismael. Fue la última gran exposición surrealista española antes de la guerra civil [...]. Entre todos exponen más de 30 obras bajo el patrocinio del ADLAN (Amics de l'Art Nou)», D. Marín Silvestre, «Remedios Varo incendiaria de la imaginación», en Solidaridad Obrera, 297 (Verano 2000), p. 3. www.soliobrera.org/pdefs/a5 pdf. 7 Oscar Domínguez (Tenerife 1906-París 1957), pintor y escultor. «In 1936 he introduced the decalcomania technique into Surrealism» (Caws 287). Él es una figura muy influyente en la vida de decalcomania technique into Surrealism» (Caws 287). Él es una figura muy influyente en la vida de Varo, él fue quien la presentó con Péret y años más tarde, en 1940, la ayudó a huir de París. Al (una revista de Tenerife dedicada a la actividad surrealista), que hacía de puente entre su país Francia [...] fue luego el organizador de varias exposiciones surrealistas, entre ellas untre su país Breton y Péret en Tenerife en 1935»; J. Kaplan, Viajes inesperados..., op. cit., p. 49. 8 Ibidem, p. 53.

9 Véase, por ejemplo, la obra de L. Clara, Inmigración y exilio. Reflexiones sobre el caso español, México: Siglo XXI Editores/El Colegio de México, 1997, que incluye una amplia bibliografía al respecto.

10 Víctor Brauner (Rumania 1903-París 1966), pintor y escultor «officialy joined the Surrealists in 1932 In 1947 abandoned Surrealism in protest at Breton's exclusion of Roberto Matta»; en M. A. Caws, Surrealism..., op. cit, p. 286.

${ }^{1}$ Wolfgang Paalen (Austria 1905-Taxco, México 1959). Pintor, escultor y escritor. «He was aligned with the surrealists movement from 1935 to 1942, and again from 1951. [...] Contributing his fumage technique to surrealist painting», ibidem, p. 291

12 Max Ernst (Alemania 1891-París 1976). Pintor, escultor y creador de collages. «He moved to Paris in 1922, exhibiting his first surrealist paintings [...] In 1925 he Developer his frottage techinque, a paralle practice to automatism», ibidem, p. 288

LECTURA Y SIGNO, 4 (2009), pp. 141-159 
los escritos de Varo las mismas cualidades significativas, la libertad en su creación, su carácter privado y el hecho de no haber sido considerados, en su mayoría, como trabajos terminados.

Remedios Varo (Anglés 1908 - Cd. de México 1963) realizó sus estudios formales de pintura en la Academia de Bellas Artes de San Fernando en Madrid de 1924 a 1930. Aun cuando la estricta formación técnica de la Academia no daba lugar a la experimentación, Varo comentó: «Todo lo que yo aprendía, lo aprovechaba para pintar por mi cuenta las cosas que me interesaban, que es lo que podemos llamar, unida a la técnica, la iniciación a la personalidad». ${ }^{2}$ Una vez concluidos sus estudios, Varo y su marido, el pintor Gerardo Lizárraga ${ }^{3}$, se marcharon a vivir a París. Posteriormente, en 1932, se instalaron en Barcelona, en donde trabajaron para la agencia publicitaria Thompson. Poco tiempo después Varo conoció al artista catalán Esteban Francés ${ }^{4}$ con quien compartiría su estudio y el interés por relacionarse con los surrealistas de la época. Las obras que Remedios Varo produjo en Barcelona, a decir de Kaplan, «demuestran que ya había desarrollado la capacidad necesaria para comprender la imaginería y los propósitos del surrealismo»..$^{5}$ En mayo de 1936, Varo participó con tres de sus trabajos en la exposición organizada por el grupo llamado «Lógicofobistas». 6 2 J. Kaplan, Viajes inesperados. El arte y la vida de Remedios Varo, México, Walter Gruen/ Era, 1998, p. 29.
${ }^{3}$ Gerardo Lizárraga (Pamplona 1905-México ?): «Durante sus años de estudiante en la Academia ganó varios premios y se dedicó a actividades sumamente variadas, realizando más tarde retratos varios premios y se dedicó a actividades sumamente variadas, realizando más tarde retratos, lustraciones comerciales, carteles polltos y mo Ibidem, p. 30 .
ing Ibidem, p. 30.

Esteban Francés (Girona, 1913-Barcelona, 1976) Pintor: «He studied in Barcelona [...] He fought on he Republican side in the Spanish Civil War. Exile in 1937, he joined the surrealist group in Paris [... After the war he returned to Spain»; en M. A. Caws, Surrealism, Londres, Phaidon Press, 2004, p. 288 A decir de Kaplan, «formaría parte de la vida de Varo en España, en Francia y también en México»; J. Kaplan, Viajes inesperados..., op.cit., p. 36.

5 Ibidem, p. 37.

${ }^{6} \mathrm{Al}$ respecto Jaime Brihuega consideró que esta exposición fue «el último rescoldo surrealista de la España anterior a la guerra civil». En Kaplan, Janet. Viajes inesperados..., op. cit., p. 44, n. 17. De esta misma exposición Dolors Marín señala: «Remedios Varo participó en la Exposición Logicofobista de las Galerías Catalonia en Barcelona en 1936. Compartía sala con Artur Carbonell, Leandre Cristófol, Angel Ferrant, Esteve Francés, A. Gamboa-Rothowss, A. García Lamolla, Ramón Marinel.lo, Joan derecho ciudadano, es percibido en esta crónica en relación con las leyes del intercambio económico y la competencia, lo que por un lado muestra la proletarización de los periodistas (la que afecta al propio Martí), y por otro lado relativiza la objetividad de la información como verdad pública irrefutable. ${ }^{4}$

Así como Martí matiza en este texto la enaltecida descripción y valoración de la prensa que había construido en el texto anterior, también matiza la idealización de los Estados Unidos, sin por ello desarticular la antítesis que lo opone a la Europa cruel. «i(A)quí los corazones no son generalmente sensibles! jaquí no hace temblar la idea de un hombre muerto por el verdugo a mano fría! ¡aquí se habitúa el alma al egoísmo y la dureza!» (57) declara enfáticamente Martí. Los norteamericanos se constituyen así, al igual que los obreros inmigrantes, como sujetos de carencia, pero no de una cultura democrática, sino de compasión, misericordia y solidaridad. Su egoísmo, sin embargo, no es total. Su compromiso social queda evidenciado en el sistema de jurados, dispositivo jurídico que involucra activamente a los ciudadanos en la administración de justicia y los somete a amenazas y posibles desquites venidos del ámbito de los acusados. Aquí, como en todas partes, dice Martí, los jurados no son «como los jueces, que viven de la justicia y pueden afrontar los peligros que les vengan de ejercerla con la protección y paga del orden social que los necesita para su mantenimiento» (59).

La crónica nos muestra al jurado ajeno a toda tendenciosidad y presenta su veredicto como fruto de la comprobación de pruebas y no de la especulación y el prejuicio. Todo, dice Martí, «se fue probando: la premeditación, la manufactura de los proyectiles, la conspiración, las excitaciones del incendio y el asesinato, la publicación de claves en el diario con este fin, el tono criminal de los discursos en la

${ }^{4}$ Esta reconsideración de la tendenciosidad periodística es interesante de observar puesto que no es frecuente en Martí quien "rara vez criticó de frente la emergencia de la «información», en tanto nueva mercancía de la emergente industria cultural. Incluso escribió por muchos años para Charles Dana director del New York Sun, una de los antecedentes principales de la prensa amarillista de Hearst y Pulitzer". En Ramos, J., op. cit., p. 110. 
junta de Haymarket, la preparación y lanzamiento de la bomba desde la carretera de los oradores» (60). Las evidencia fue tanta que «(a)nonadaba tanta prueba. Estremecía lo que se había oído y visto. Trascendía al tribunal el espanto público» (60). Dentro del tribunal, y como ya lo había hecho en la crónica anterior con otros personajes, Martí confronta a los actores que se comportan de un modo antagónico. «Sin miedo hablaron el fiscal y su abogado. Sin fortuna ni solidez hablaron los defensores» (60). La oposición se plantea como una descripción y pone en juego una valoración que acentúa la distancia axiológica entre los enaltecidos defensores de los policías muertos en el atentado y los desacreditados defensores de los anarquistas inculpados del delito. Subyacente a esta contraposición actancial, la crónica trabaja otra dicotomía más amplia, la que se da entre el statu quo ponderado y la desorganización social temida.

El caos social no concluye con el apresamiento de los siete anarquistas implicados en el crimen, ni con la sentencia que los condena a muerte. Contrario a esto, cuando se anuncia el veredicto se siente, señala Martí, «que en esta masa de millones hay todavía rincones vivos donde se hacen bombas, se reúnen en Nueva York dos mil alemanes a condolerse de los sentenciados, se sabe que no han cesado en Chicago, ni en Milwaukee, ni en Nueva York los trabajos bárbaros de estos vengadores ciegos» (58). El cubano se pronuncia contrario a los métodos violentos de negociación en la lucha obrera, cuyos fundamentos y expresiones son motivo de reflexión y posicionamiento explícito.

«El que más, el extranjero de alma compasiva, el pensador que ve en las causas, se entristecían y callaban» (59), sostiene Martí, que presenta así una autofiguración de sí mismo como pensador extranjero sensible a la realidad del país en el que reside. La estrategia lingüística mediante la que se refiere a sí mismo es interesante porque, por un lado, se ajusta, a través de la tercera persona singular predicada, a cierto distanciamiento descriptivo frecuente en la escritura de los reporters; pero, por otro lado, y por la identificación de los atributos de esa tercera

\section{LOS «BOCETOS» DE REMEDIOS VARO}

EDITH MENDOZA BOLIO Instituto Tecnológico de Monterrey sin embargo, adentrarse en la obra escrita de esta artista española, exiliada en México, amplía la comprensión de su imaginario. En algún momento de la vida de Varo le preguntaron «¿Es usted escritor así como es pintor?» a lo que ella contestó: «A veces escribo como si trazase un boceto». ${ }^{1}$ Esta respuesta puede contener las claves para interpretar el significado que la escritura tenía para ella. El trazo de un boceto es un ejercicio inacabado y libre que apunta a convertirse, tras horas de trabajo, en una obra terminada. Es posible, por lo tanto, identificar en la mayoría de

* Recibido: 14-01-2009 Aceptado: 05-03-2009

${ }^{1}$ Entrevista publicada en I. Castells, Remedios Varo. Cartas, sueños y otros textos, México, Era, 1997, p. 68 


\section{BIBLIOGRAFÍA}

GARCÍA MARRUZ, F., “El tiempo en la crónica norteamericana de José Martí” (175194), Temas martianos, Tercera serie, La Habana, Centro de Estudios Martianos - Ediciones Artex, 1992.

MARTÍ, J., “Grandes motines obreros” (445-56), “El proceso de los siete anarquistas” (55-61) y "Un drama terrible" (333-56), en Obras Completas. Vol. XI, La Habana, Editorial de Ciencias Sociales del Instituto Cubano del Libro, 1975.

MINELLONO, M., "La modernidad y la concepción del tiempo en «Nuestra América» y «Escenas norteamericanas» de José Martí" (241-251), Actas del Primer Congreso de Estudios Latinoamericanos, La Plata, Facultad de Humanidades y Ciencias de la Educación - UNP, 1994

RAMOS, J., Desencuentros de la modernidad en América Latina. Literatura y política en el siglo XIX, México, FCE, 2003.

ROTKER, S., La invención de la crónica, Buenos Aires, Ediciones Letra Buena, 1992.

WILLIAMS, R., Marxismo y literatura, Barcelona, Ediciones Península, 2000. persona con el escritor cubano, sobreimprime a su discurso el subjetivismo de la mirada típico del cronista modernista. ${ }^{5}$ Entre el periodismo y la literatura, Martí delinea su figura de escritor y su lugar en la sociedad, es decir, su relación con aquellas instancias que podríamos llamar extraliterarias. La posición del cronista respecto de los líderes anarquistas, responsabilizados y condenados, en este texto, por la muerte de un grupo de policías, continúa la línea axiológica del texto anterior, del que también repite la construcción de prosopografías connotadas que acentúan y relacionan sus defectos estéticos con sus faltas éticas.

El retrato de Schwab, uno de los anarquistas procesados, evidencia el rechazo que su figura provoca en Martí. Schaw es presentado como un ser «desgarbado, repulsivo, de funesta apariencia; la mirada caída bajo los espejuelos, la barba silvestre, el pelo en rebeldía, la frente no sin luz, el conjunto como de criatura subterránea» (60). En esta descripción opera una fuerte poetización del referente que es, tal como advierte Rotker, «parte de la «literariedad»y de la condición de prosa poética de las crónicas modernistas» (155)

La tercera crónica, "Un drama terrible", es la encargada de resemantizar muchas de las imágenes y de las valoraciones trabajadas por las dos anteriores en relación con el conflicto obrero, sus causas, los actores implicados y las reglas sociales hegemónicas de la sociedad norteamericana. Este texto representa un cambio en la mirada del cronista respecto de los hechos que observa y narra, transformación que, por un lado, continúa con la auto-figuración de una autoridad narrativa reflexiva, «el pensador que ve en las causas» ("El proceso" 59) aludido en la crónica antes comentada, pero que, por otro lado, subvierte y rompe la continuidad axiológica y los esquemas interpretativos hasta entonces referidos al juzgamiento judicial y social de los anarquistas en particular, y a la lucha obrera en general.

5 "Los cronistas modernistas acentuaron el subjetivismo de la mirada y sobrescribieron, para
diferenciarse de los reporters" explica Susana Rotker. Ver op. cit., p. 109. 
El procedimiento lingüístico mediante el que la figura de Martí emerge en la crónica repite el utilizado en "El proceso de los siete anarquistas": el escritor se refiere a sí mismo a través de una tercera persona singular que proporciona a su texto la "externidad" enunciativa tan buscada por los reporters; pero, a su vez, ofrece manifiestas estampas de su subjetividad en un frecuente gesto modernista. En el primer párrafo de la crónica sostiene que:

Ni el miedo a las justicias sociales, ni la simpatía ciega por los que las intentan, debe guiar a los pueblos en sus crisis, ni al que las narra (...). No merece el dictado de defensor de la libertad quien excusa sus vicios y crímenes por el temor mujeril de parecer tibio en su defensa. Ni merecen perdón los que, incapaces de domar el odio y la antipatía que el crimen inspira, juzgan los delitos sociales sin conocer y pesar las causas históricas de que nacieron, ni los impulsos de generosidad que los producen (333).

Las predicaciones de la cita le corresponden al pueblo norteamericano, a sus representantes y funcionarios, y al propio cronista, a quien afectan particularmente las reglas morales que expresa en términos deónticos y negativos. El pasaje referido entrama una fuerte imagen de autor en la que convergen las labores de narrador y pensador. Los hechos, lejos de constituir una realidad autónoma, se articulan con la expresión que los informa y la reflexión que los explica. La presentación y organización discursiva de los acontecimientos se liga explícitamente a conjunto de postulaciones sociales que representan una innovación en el discurso martiano: la necesidad de equidad social ahora señalada revisa y relativiza la antes ensalzada organización social republicana, la categoría de «delito social» atenúa y contextualiza la responsabilidad y la criminalidad de los anarquistas, antes simples malhechores y ahora actores socialmente motivados.

En el párrafo inicial aparecen nuevas expresiones y nuevas ideas, por ejemplo la de «justicias sociales», que se reiteran a lo largo de la crónica y que representan un elemento disruptivo con respecto a las crónicas anteriores tanto a nivel del significante como del significado. Las variaciones en el plano léxico bien pueden interpretarse como proyecciones de las mutaciones en el paradigma interpretativo martiano que al resignificar sus ideas se vale, entre otras cosas, de un nuevo explicativa tanto para la aceptación del statu quo de los grupos acomodados como para las medidas de lucha implementadas por los obreros como grupo subalterno.

Por su parte, el "acá" geopolítico de la enunciación se define, como señalamos en el desarrollo, en relación con las propias experiencias biográficas de Martí en Estados Unidos, país que le ofrece la oportunidad de desarrollar libremente su tarea de escritor y simultáneamente le proporciona una versión hegemónica y positiva de su organización social. Dicha versión es difundida por los periódicos oficiales que en la primera crónica son exhibidos por Martí como herramientas transparentes de divulgación, pero que ya en la tercera crónica aparecen como máquinas de manipulación de la información. La contraposición de los dos primeros textos entre una Norteamérica idealizada y una Europa retrógrada desprovista de mecanismos democráticos y reglas de consenso social da paso en el último a una equiparación entre estas sociedades que les ofrecen a los obreros la misma explotación y marginación.

Los tres textos de nuestro análisis presentan varias continuidades típicas de las crónicas modernistas, a cuya gramática de producción se ajustan en términos generales, con una fuerte impronta de subjetividad y una constante poetización de lo real. La sobre-escritura es una de las continuidades, así como la explícita autofiguración del escritor en la que, por un lado, se superponen las figuras de pensador, cronista y literato, y, por el otro, se oscila entre las técnicas de descripción y narración más realistas, cercanas a la objetividad pretendida por los reporters, y la constante estilización y poetización de los referentes. 
percepción y valoración del entorno que acompaña a los líderes procesados por la muerte de un grupo de policías. En las dos primeras crónicas éstos eran considerados violentos criminales en los que preponderaba un odio irracional hasta las leyes republicanas, en la última son retratados como frágiles seres cuyas demandas justas son desoídas y combatidas por una república desequilibrada e injusta.

Los cambios axiológicos acompañan las variaciones en los modos de procesar la información y sus fuentes. La tercera crónica representa, al respecto, una fuerte ruptura respecto de las anteriores. "Un drama terrible" revierte la versión maniquea de los hechos que la prensa, el gobierno y los capitalistas difundían y que el propio Martí reproducía en los dos primeros textos; y retoma las voces de los trabajadores como fuentes fidedignas de su relato. Al incorporar nueva información, además, la crónica ofrece nuevos elementos a la luz de los cuales es necesaria y válida la revisión de las explicaciones y las evaluaciones de los acontecimientos, de sus protagonistas y sus motivaciones. Esta crónica impugna la hiperbolizada idealización de la valentía y entrega de los policías que las anteriores construyeron al informar de su constante abuso de autoridad, refuta la idea de una república que propende a la justicia y a la libertad y remarca su tendencia a la iniquidad, asociando la conducta de los funcionarios del estado, así como las operaciones de la prensa, no con la persecución del bien común sino con los intereses de clase, con la defensa de un sistema económico y social asimétrico que controla arbitraria e injustamente una voluntad sectorial capitalista.

Junto a los cambios anteriores la tercera crónica visibiliza la redefinición de la inmigración y la desarticulación de la dicotomía América-Europa. En “Grandes motines obreros" y en "El proceso de los siete anarquistas" las identidades de los sujetos se diferenciaban principalmente según los perfiles ideológicos fuertemente dicotomizados y determinados por la nación de origen. En "Un drama terrible", en cambio, la identidad se liga estrechamente a la noción de clase, la que se torna vocabulario, mostrando el vínculo indisociable entre lenguaje y pensamiento. Nuevos modos de pensar los hechos, entonces, requieren nuevos modos de expresarlos y configurarlos discursivamente.

"Un drama terrible" tiende a la retrospección. Rememora los sucesos más cercanos en el tiempo, como la muerte y el entierro de los cuatro anarquistas sentenciados en Chicago a la horca y del que hizo estallar en su propio cuerpo una bomba de dinamita, y de allí se desliza hacia atrás y recuerda la sentencia que «condenó a uno de los reos a quince años de penitenciaría y a pena de horca a siete» (333), las voces que se alzaron en defensa de los condenados, la explotación e injusticia que viven los obreros en Estados Unidos, la constante represión que sufren por parte de la policía en sus manifestaciones, las primeras revueltas, la organización anarquista y sus modos de entrenamiento y adoctrinamiento.

La crónica recuerda acontecimientos ya relatados en las crónicas anteriores, por ejemplo, el inicio de las huelgas, los enfrentamientos entre trabajadores y policías, y la reacción adversa de las fábricas que echaban a los obreros que presentaban su demanda. Pero agrega algunos incidentes que antes no fueron narrados y que revierten la versión de los hechos sostenida por la prensa oficial, el estado y los dueños de las fábricas y el propio Martí en las dos crónicas anteriores. Dos de ellos son fundamentales para explicar el cambio en el discurso y en el pensamiento martiano: los sucesos ocurridos en el Camino Negro que lleva hacia la factoría McCormick y las anomalías y vicios que empañan el proceso a los anarquistas condenados por la muerte de unos policías.

En el primero de estos hechos los trabajadores en huelga se enfrentan, por un lado, con sus compañeros que continúan trabajando, y por otro lado, con la policía. Los huelguistas señalan a «iaquéllos, (...) los que por el salario de un día ayudan a oprimir a sus hermanos!» (345) y los apedrean. La policía llega entonces al lugar y abre fuego sobre la muchedumbre «que a pedradas y disparos locos se defiende» 
(345). El resultado de ese choque es el de seis obreros muertos. El suceso obliga a revisar la dicotomía entre obreros ignorantes y cultos que las crónicas anteriores establecieron, así como la heroicidad de la policía.

El no acatamiento a la huelga no se presenta en "Un drama terrible" como un posicionamiento laboral surgido de la libre y deliberada elección de algunos trabajadores, sino que aparece, por el contrario, como una forzada respuesta de aquellos «a quienes la miseria fuerza a servir de instrumentos contra sus hermanos» (344). No existe una real división entre los trabajadores: todos son víctimas de la misma explotación. Son los propietarios de las fábricas quienes propenden a la desintegración del movimiento obrero, empleando para enfrentarse a quienes luchan contra el hambre a «las mismas víctimas desesperadas del hambre» (344).

La policía, por su parte, va a ser revaluada a la luz de la nueva información que la muestra violenta y autoritaria, lejos de la figura conciliadora y mesurada que las crónicas anteriores habían desplegado hasta la idealización. La policía que mata a los seis obreros en McCormick es la misma que, en Chicago, se les echaba encima a los trabajadores que exigían sus derechos, «ganosa siempre de cebar sus porras en cabezas de gente mal vestida» (339); es también quien «ebria del vino del verdugo como toda plebe revestida de autoridad» (343) provoca con sus fiestas de sangre la decisión de los más bravos de armarse; es la «que les da caza y muerte» (343) a los huelguistas y «con el orgullo de la levita de paño y la autoridad, temible en el hombre inculto, los aporrea y asesina» (338).

La policía en Chicago no actuaba, como antes sostuvo el cubano, «con la calma de la ley, sino con la prisa del aborrecimiento» (344) hacia los obreros, muchos de los que terminaban «magullados por la porra o atravesados por la bala policial» (344). La hiperbolización de su valentía, que en las crónicas anteriores se construye y acentúa en la confrontación que la opone a sujetos considerados abyectos, se revierte totalmente. La cobardía de los policías se enfatiza al reiterar los ataques ilegales e sujetos de carencia, no como los primeros de una cultura democrática, sino de sensibilidad social y solidaridad. Conjuntamente con la desidealización de los Estados Unidos se produce una aproximación del cronista hacia los trabajadores, aproximación que se manifiesta plenamente en la última crónica en la que un nuevo paradigma interpretativo se proyecta en un nuevo repertorio léxico, en el que se repiten con insistencia, entre otros términos antes infrecuentes en la escritura martiana, las palabras "víctima" y "justicia", predicando respectivamente la condición y la búsqueda social de los trabajadores.

El acercamiento axiológico a los trabajadores y la modificación de los esquemas explicativos del conflicto obrero, de sus necesidades y demandas, se manifiesta en la resemantización de los procedimientos discursivos mediante los que se los describe. La animalización de los personajes, por ejemplo, que en la primera crónica apunta a hacer bestiales a los huelguistas, a quienes deshumaniza y desvaloriza ideológica y físicamente presentándolos como animales peligrosos y dañinos para la sociedad, en la tercera crónica le quita rasgos humanos a la sociedad norteamericana y subvierte la connotación negativa que antes afectaba a los trabajadores activistas. Así, mientras en "Grandes motines obreros" Martí celebra que el aire de libertad que impera en Estados Unidos «ene una enérgica virtud que mata a las serpientes» (456), que refieren a los obreros anarquistas y socialistas, en un "Un drama terrible" recupera y transcribe, sin comentarios adversos, el discurso de un anarquista que les recomienda a sus compañeros, luego de la ejecución de un grupo de ellos, ser «gaces como las serpientes, e inofensivos como las palomas» (356).

También las descripciones de los anarquistas van a cambiar a lo largo de las crónicas. En las dos primeras el rechazo ideológico hacia ellos repercute en y se articula con su desvalorización estética. Los tres textos ofrecen prosopografías connotadas que tienden a constituirse en retratos morales que se resignifican conforme cambia la opinión de Martí sobre ellos en una dirección que va desde el rechazo hasta el reconocimiento. Junto con esto observamos la modificación de la 
axiológica y epistemológica en relación con los hechos relatados y los personajes descritos.

El primero de los movimientos recién aludidos parte en "Grandes motines obreros" de un recorte narrativo general referido a las huelgas y otras acciones de lucha que los obreros realizan en Estados Unidos para reducir la jornada laboral a ocho horas. En los obreros, como un actor colectivo, se focaliza el relato. La segunda crónica reduce el núcleo de interés narrativo y se centra en el proceso judicial de los siete anarquistas responsabilizados de arrojar, en la huelga de la primavera en Chicago, una bomba que mató a un grupo de policías. La tercera, finalmente, ciñe aún más el foco de atención y se refiere, principalmente, a los procesados condenados a la horca y con un detenimiento particular a las reacciones que preceden sus ejecuciones. El pasaje que las crónicas proponen es el que lleva de los hechos y actores indistintos a los acontecimientos y sujetos únicos y originales. Se parte de lo estereotípico para llegar a lo característico, de la masa para llegar al individuo.

El segundo de los movimientos antedichos, en consonancia con el primero, muestra que a lo largo de los textos se produce un acercamiento afectivo e ideológico hacia el sector obrero y sus demandas. En la primera crónica dicho sector se percibe fragmentado en dos grupos antagónicos que reciben axiologías antitéticas. Por un lado se presentan los trabajadores moderados, pacifistas y conciliadores, y por otro los radicalizados, violentos e irracionales antagonistas del orden social, despreciados explícita y enfáticamente. En la segunda crónica se continúa esta línea axiológica que dicotomiza al mundo obrero y a la sociedad en general y se repite el uso de deícticos ligados a los huelguistas como marcas textuales del distanciamiento establecido con respecto a ellos y a sus teorías sociales. Sin embargo, "El proceso de los siete anarquistas", a la vez que continúa rechazando a los obreros activistas, matiza la idealización de la organización republicana estadounidense que la crónica anterior impulsó, y reconoce que los norteamericanos también, como los inmigrantes, son ilegítimos que emprenden contra los niños hijos de obreros. La policía mataba, dice el cronista, «a veces a algún osado que le resistía con piedras, o a algún niño» (339), y repite el dato páginas más adelante, ofreciendo un ejemplo concreto del criminal abuso de autoridad policial. A través de las palabras que un obrero le dirige al gobernador, Martí recuerda que mientras siete anarquistas fueron condenados a la pena de muerte porque uno de ellos habría lanzado una bomba contra la policía, «los tribunales no han querido condenar a la policía de Pinkerton, porque uno de sus soldados mató sin provocación de un tiro a un niño obrero» (350).

Además de revisar los antagonismos entre policías y obreros y modificar la caracterización de estos grupos y sus valoraciones, "Un drama terrible” cambia los términos con que se describen no sólo a los anarquistas, sino también a sus ayudantes, a su círculo íntimo de amigos y familiares. Mientras las dos crónicas anteriores acentuaban lo poderosamente dañino de este último grupo, ésta retrata a los personajes ligados a los anarquistas como seres débiles guiados por la bondad y el amor. Al respecto, Martí sostiene que:

La república entera ha peleado, con rabia semejante a la del lobo, para que los esfuerzos de un abogado benévolo, una niña enamorada de uno de los presos, y una mestiza de india y español, mujer de otro, solas contra el país iracundo, no arrebatasen al cadalso los siete cuerpos humanos que creía esenciales a su mantenimiento (334).

La cita propone una antítesis y un asimétrico enfrentamiento de fuerzas: la bestialidad de la república combate la fragilidad y benevolencia del núcleo de actores cercanos a los anarquistas. La animalización que en los textos anteriores deshumanizaba a estos últimos, ahora le quita rasgos humanos a la sociedad norteamericana. El repertorio de valores que Estados Unidos desarrolla y jerarquiza se halla en las antípodas de los anhelados por el grupo más próximo a quienes juzga y condena. Esos valores, apreciados por Martí, son ejemplificados a través de Howells, Adler y Train, las tres voces que «habían osado interceder, fuera de sus defensores de oficio y sus amigos naturales» (334), en la defensa de los anarquistas procesados. 
Howells era un «novelista bostoniano que al mostrarse generoso sacrificó fama y amigos» (334), Adler era un «pensador cauto y robusto que vislumbra en la pena de nuestro siglo el mundo nuevo» (334-35), y Train era «un monomaníaco que vive en la plaza pública dando pan a los pájaros y hablando con los niños» (334-35). Todos eran, como se desprende de sus descripciones, sujetos inofensivos, generosos hasta el altruismo o la locura, distantes de la violencia, e identificados con la solidaridad y la concordia social.

Mientras en las dos crónicas anteriores Martí representaba simultáneamente la voz popular y oficial de un estado de cosas, aquí se distancia del discurso del gobierno y relativiza su validez epistemológica y su legitimidad social. La "república", sintagma que reaparece con frecuencia en este texto, es vitalizada y personalizada. Se le adjudica una voluntad arbitraria y propensa a acrecentar las injusticias. En la crónica se sostiene que:

Amedrentada la república por el poder creciente de la casta llana, por el acuerdo súbito de las masas obreras (...), por el deslinde próximo de la población nacional en las dos clases de privilegiados y descontentos que agitan las sociedades europeas, determinó valerse por un convenio tácito semejante a la complicidad, de un crimen nacido de sus propios delitos tanto como del fanatismo de los criminales, para aterrar con el ejemplo de ellos, no a la chusma adolorida que jamás podrá triunfar en un país de razón, sino a las tremendas capas nacientes (334)

Responsabilizada la sociedad misma por la fragmentación y la proliferación de la inequidad social que la dicotimiza, sus reglas sociales y económicas se asocian no como en los dos textos anteriores a la idea del bien común sino a los intereses de clase. Estados Unidos, dice Martí, «por el culto desmedido a la riqueza, ha caído, sin ninguna de las trabas de la tradición, en la desigualdad, injusticia y violencia de los países monárquicos» (335). El materialismo desmedido que se les achaca a los norteamericanos es la plataforma sobre la que opera la corrupción y parcialidad social que practican la policía, los funcionarios públicos, la prensa y los sectores económicamente más acomodados en relación con la lucha obrera en general y con el proceso y la condena de los anarquistas en particular. espacio público su desigualdad, iniquidad y su autoritarismo. Un ejemplo de lo antedicho se encuentra en los frecuentes pasajes de esta crónica que relatan cómo el gobierno y los capitalistas, a través de la policía, despliegan en las plazas y otros lugares públicos un poderoso mecanismo de vigilancia, control y castigo del que son víctimas los obreros. Tal como se ve la escritura martiana «decora, no resuelve las tensiones de la ciudad: al contrario - muy por el reverso de los patrones de la prosa estilizada que domina en la crónica modernista - parecería que la fragmentación del cuerpo del otro contamina, con su violencia, el espacio mismo del discurso» (Ramos 141)

\section{CONCLUSIÓN}

Las tres crónicas periodísticas comentadas, cuyo carácter literario se deriva «la voluntad de escritura, del cómo se ha verbalizado su discurso» Rotker (113), tratan sobre la problemática obrera que, a partir de mayo de 1886, emerge con fuerza en Estados Unidos. Sin embargo, hay que precisar esta continuidad temática considerando precisamente la configuración discursiva de los referentes que va a modificarse en cada texto. No es la misma lucha obrera ni son los mismos obreros los descritos en la primera crónica que los apuntados en la última. Estas variaciones semánticas patentizan el hecho de que «significado es siempre producido y no es jamás expresado simplemente» (Williams 190). Si en los primeros dos textos el activismo obrero representaba una anomia social, en el tercero encarna la emergencia de un grupo y de una práctica social. ${ }^{7}$ Leídas en conjunto podemos observar que las crónicas realizan un movimiento de focalización temática y uno de aproximación

${ }^{7}$ Martí reconoce en la última crónica al movimiento obrero como un elemento social emergente en el sentido popularizado por Raymond Williams, es decir, en el que define como emergente aquellas experiencias grupales alternativas u opuestas a la formación cultural dominante que las rechaza a la vez que busca incorporarlas y adaptarlas a sus definiciones de lo social. Ver, al respecto, el capítulo "Dominante, residual y emergente" de su obra Marxismo y literatura, Barcelona, Ediciones Península 2000, pp. $143-49$ 
penurias del trabajador alemán que lo declama y de los otros trabajadores que comparten las evocaciones textuales a un mundo injusto y arbitrario. El momento en que Engel, "arrebatado por el éxtasis, recitaba "El Tejedor" de Henry Keine, como ofreciendo al cielo el espíritu, con los dos brazos en alto (351), es en el que mayor cercanía empática con los prisioneros, establece Martí. El condenado devenido en orador es descrito a través de la deriva metonímica de su voz «llena de fuerza y sentido, la voz de uno, de estos hombres a quienes se supone fieras humanas, trémula primero, vibrante enseguida, pura luego y serena, como quien ya se siente libre de polvo y ataduras» (351)

La idea de la no representatividad que las crónicas anteriores les endilgaban a los dirigentes obreros es rebatida en esta crónica que marca el acompañamiento popular y multitudinario de las distintas medidas de lucha. La adhesión masiva se marca cuantitativamente y se traduce en cifras concretas. Así, fue un «millón de obreros, repartidos por toda la república» (344) el que decidió demandar el cumplimiento de las ocho horas legales (344); fue un grupo de «ocho mil» (345) obreros huelguistas el que se acercó a la fábrica McCormick que continuaba trabajando; fue «en número de cincuenta mil» (346) que se agruparon los trabajadores, con sus mujeres y sus hijos, para oír «a los que les ofrecían dar voz a su dolor» (346); y finalmente fue una numerosa caravana la que acompañó el cortejo fúnebre; tras los ataúdes iban las viudas y detrás de ellas «sociedades, gremios, vereins, orfeones, diputaciones, trescientas mujeres en masa, con crespón al brazo, seis mil obreros tristes y descubiertos que llevaban al pecho la rosa encarnada» (355).

Los obreros, como se desprende de los ejemplos anteriores, ya no se presentan segmentados ni se organizan en dicotomías maniqueas, tampoco los huelguistas representan la otra cara de una sociedad pacifista, sino que, por el contrario, son parte constitutiva de una sociedad compleja y fragmentada que proyecta en el

comprados, uno de ellos confeso de perjurio (...). Lo que sí se probó con prueba plena, fue que, según todos los testigos adversos, el que arrojó la bomba era un desconocido" ("Un drama terrible", p. 348).
Las autoridades públicas, a las que anteriormente no se habían responsabilizado del conflicto obrero, sus causas y efectos, son criticadas. El gobernador de Chicago, por ejemplo, es descrito como un «anciano flojo rendido a la súplica y a la lisonja de la casta rica que le pedía que, aun a riesgo de su vida, salvara a la sociedad amenazada» (334). La prensa, por su parte, exaspera a los anarquistas «con su odio en vez de aquietarlos con justicia» (342) y tiene una fuerte responsabilidad en la negativa valoración social de las huelgas y los huelguistas. La prensa tal como en esta crónica la describe Martí no es una herramienta de comunicación fidedigna del conflicto obrero ni del proceso judicial de los anarquistas, sino un instrumento de manipulación informativa. Sobre este punto Martí explica que:

(1)a prensa entera, de San Francisco a Nueva York, falseando el proceso, pinta a los siete condenados como bestias dañinas, pone todas las mañanas sobre la mesa de almorzar, la imagen de los policías despedazados por la bomba; describe sus hogares desiertos, sus niños rubios como el oro, sus desoladas viudas (349).

Los periódicos funcionan entonces, al igual que los policías y algunas autoridades, como dispositivos de una voluntad sectorial capitalista, voluntad que reacciona de un modo desmedido y despótico ante los reclamos más primordiales y legítimos de los obreros. Cada vez que ellos realizaban sus pedidos en Chicago «combinábanse los capitalistas, castígábanlos cegándoles el trabajo que para ellos es la carne, el fuego y la luz; echábanles encima la policía, (...); reducíanlos al fin por hambre a volver a su trabajo, con el alma torva, con la miseria enconada, con el decoro ofendido, rumiando venganza» (339).

Así como esta crónica modifica, con respecto a las dos anteriores, la interpretación del problema de los trabajadores en Estados Unidos y la opinión sobre los grupos implicados y sus razones, también revisa y redefine la postura sobre la inmigración. Los obreros inmigrantes no aparecen ahora, como sí lo hacían en los primeros textos comentados, como criaturas de un odio remoto, más bien se los retrata como sujetos de derechos cuyas violaciones son las causas principales de la 
reacción anarquista. Ellos sólo reaccionan y denuncian «con renovada ira los males que creían haber dejado tras sí en su tiránica patria» (335).

Martí sostiene que la república de Estados Unidos se ha convertido en «una monarquía disimulada» (335) luego de que el país experimentara, entre otras cosas, «la guerra corruptora, el hábito de autoridad y dominio que es su dejo amargo, el crédito que estimuló la creación de fortunas colosales y la inmigración desordenada» (335). La injusticia y tiranía de los poderosos acerca a América del Norte a la Europa más retrógrada y desarma la dicotomía que antes las oponía. Tal como redacta enfáticamente Martí, para los trabajadores inmigrantes «¡América es, pues, lo mismo que Europa!» (338).

"Un drama terrible" es la más extensa de las crónicas periodísticas analizadas y es en la que mejor se transparenta la idea de Julio Ramos de que la lógica del sentido del periódico está «constituida por una acumulación de fragmentos de códigos, en que los lenguajes se sobreimponen, yuxtaponen o simplemente se mezclan, con discursos de todo tipo y procedencia histórica imprecisable» (124). Lo dicho sucede en este texto que incorpora, entre otras formas del lenguaje, frecuentes proposiciones enfáticas y preguntas retóricas más ligadas a la arenga pública y política que a la crónica periodística; breves alocuciones de los actores de los acontecimientos, recurrentemente innominados y generalmente provenientes de la clase trabajadora; el poema "El Tejedor" de Henry Keine recitado por uno de los condenados y traducido y trascrito íntegramente; y enunciados que tienden a teatralizar la narración y funcionan como didascalias que escenifican las acciones y espectacularizan los movimientos, los gestos y los parlamentos de los personajes.

Cada uno de los discursos antedichos tiene efectos específicos y en conjunto revelan una operación enunciativa mayor. Los énfasis y las preguntas retóricas usualmente destacan y acentúan las opiniones del cronista y las de los obreros, con los que el primero se conduele. Esto sucede, por ejemplo, cuando Martí, en clara defensa de la causa obrera, exclama: «iQuien quiera saber si lo que pedían era justo, venga aquí; véalos volver, como bueyes tundidos, a sus moradas inmundas, ya negra la noche; véalos venir de sus tugurios distantes, tiritando los hombres, despeinadas y lívidas las mujeres, cuando aún no ha cesado de reposar el mismo sol!» (344). Y cuando se pregunta: «¿Quién que sufre de los males humanos (...) no siente que se le inflama y extravía cuando ve de cerca, como si le abofeteasen, como si lo cubriesen de lodo, como si le manchasen de sangre las manos, una de esas miserias sociales que bien pueden mantener en estado de constante locura a los que ven podrirse en ellas a sus hijos y a sus mujeres?» (337).

Ejemplos como los anteriores, a los que se añaden las voces reproducidas de los protagonistas, se imbrican para el despliegue de una «retórica de la oratoria» por la que Martí siente un particular apego (Rotker 157-58). Por otra parte, el hecho de que las palabras reproducidas correspondan mayoritariamente al sector obrero fortalece la versión que de los hechos ofrece este grupo. Esta estrategia enunciativa no representa sólo una modificación discursiva de Martí respecto de las crónicas anteriores sino también un cambio epistemológico, puesto que mientras en los dos textos anteriores la información provenía básicamente de los medios y el gobierno, ahora procede de los trabajadores.

La inclusión del poema de Henry Keine, así como la teatralización de los pronunciamientos obreros, subvierte la axiología negativa que construyeron los anteriores retratos físicos y morales de los líderes obreros, y coadyuva a apuntalar una imagen del héroe mártir en la que se engloban los anarquistas condenados a muerte, a quienes la crónica plantea como víctimas sociales, injusta e infundadamente castigadas, y a la vez como esforzados y convencidos líderes de la lucha obrera. 6 El poema "El Tejedor" de Keine se identifica con la historia de

${ }^{6} \mathrm{Al}$ respecto, Martí señala: “ ¿El proceso? Todo lo que va dicho, se pudo probar; pero no que los ocho anarquistas, acusados del asesinato del policía Degan, hubiesen preparado, ni encubierto siquiera, una conspiración que rematase en su muerte. Los testigos fueron los policías mismos, y cuatro anarquistas

LECTURA Y SIGNO, 4 (2009), pp. 107-140 
conservada de esa época, Dámaso Alonso escribe al amigo agradeciéndole el envío de La poesía española contemporánea (1954), un estudio preparado por Max Aub sobre varias conferencias dictadas en la UNAM en el año 1952. La misiva de Alonso da cuenta además de una colaboración reciente del académico para la Revista de la Universidad de México (donde Aub actuaba como intermediario), muy apurado por varias erratas en uno de sus poemas, lo que indica, al menos, que su trato del momento era ya bastante fluido, al menos, en lo que a proyectos comunes se refiere.

El texto inédito que aquí se presenta está fechado en el año 1955. Dámaso Alonso ha enviado a Max Aub su nuevo libro, Hombre y Dios, un texto claramente menor que sus Hijos de la ira, que pasó desapercibido, no sólo entre lo más de la crítica española del momento, sino muy especialmente entre los poetas en activo del interior, ya en plena evolución hacia la llamada poesía social. Max Aub, que valora muy generosamente el libro, acompaña el comentario de una carta previa en la que se aportan algunos datos históricos de interés. Además de sus críticas sobre las publicaciones de la editorial Gredos en España (ciertamente interesantes), importa subrayar que el exiliado se interesa particularmente por los nuevos poetas aparecidos en el interior desde comienzos de los años cincuenta (Gabriel Celaya, Blas de Otero, Victoriano Crémer, Ángela Figuera y Eugenio de Nora). Ésa es la primera noticia que tenemos acerca de la génesis de su volumen Una nueva poesía española contemporánea, antología crítica editada en 1956 por la UNAM, donde Max Aub analiza los nuevos caminos de la lírica española bajo la dictadura franquista. Ello es especialmente interesante. A más de quince años del final de la Guerra Civil, Max Aub no reconoce a algunos de los autores y pide ayuda a su amigo, lo que en sí mismo ilustra la formidable desconexión entre el universo del exilio y del interior, las dificultades de sus contactos y la precariedad en la circulación de sus respectivos textos-siempre de forma clandestina o por correspondencia privada.

Al margen ya de las aportaciones más históricas de la carta, cabe valorar también la originalidad de los comentarios que Aub envía a Alonso. Se trata de una
Una vez que me vi embarcada, respiré, pero el viajecito era de los de órdago también como el barco llevaba unas cuatro veces más viajeros de los que cabían normalmente, no aglomeraron en las bodegas. Para qué os voy a contar lo que es estar en una bodega con otras cien personas y con unas temperaturas tropicales, sin contar el mareo, yo no lo pude aguantar y agarré mi colchoneta y me subí a cubierta, donde hice todo el viaje; estuve en las islas Bermudas, en Santo Domingo y Cuba; sólo en Cuba me pude bajar del barco a dar un vistazo a La Habana, que me pareció un lugar suculento y paradisíaco. Llegué a Veracruz en los huesos y de allí trepé a esta ciudad de México. ${ }^{19}$

Después de tan difícil viaje, Varo y Péret se instalaron en la ciudad de México, ${ }^{20}$ lugar que consideraban como un refugio temporal, de manera que, más que integrarse a los círculos sociales e intelectuales mexicanos de la época, procuraron la convivencia con los europeos con quienes compartían un pasado común y con los que formaron un grupo muy cercano y solidario. ${ }^{21}$ Uno de los encuentros más felices para Varo fue el que tuvo con Leonora Carrington; con ella establecieron una profunda amistad. ${ }^{22}$ Varo veía en Carrington «una aliada que no trataría de explicar sus angustias con una lógica fácil, o socavar sus visiones a base de sentido común».23

Remedios Varo desempeñó diversas actividades: trabajó como decoradora de muebles finos, participó con Marc Chagall en los diseños de sombreros y tocados para el ballet de Léonid Massine, Aleko, que se estrenó en el Palacio de Bellas Artes,

19 B. Varo, Remedios Varo: en el centro del microcosmos, Madrid, Fondo de Cultura Económica, 1990, p. 217

${ }^{20}$ Con respecto al arribo de Varo y Péret, Juan Somolinos escribió: «Silenciosamente en 1942, el matrimonio Péret llegó a México [...] Los efectos de la guerra callaron a esta productiva pareja que permaneció en mutismo; sobre todo el mismo Péret cuyo paso por este país fue casi anónimo»; J. Somolinos P., El surrealismo en la pintura mexicana, México, Arte, 1973, p. 73.

${ }^{21}$ Esta situación la ratifica José Emilio Pacheco: «En los cuarentas, la ciudad de México se convierte en un centro surrealista gracias a la presencia de poetas como Benjamin Péret y César Moro, cineastas como Luis Buñuel, pintores como Leonora Carrington, Remedios Varo y Wolfgang Paalen» Pacheco, José Emilio. «La Batalla del Surrealismo (Octavio Paz y la Revista Estaciones)». En: P. G. Erle, C Gullón (eds.), Surrealismo/Surrealismos. Latinoamérica y España, Philadelphia, University of Pennsylvania, 1975, pp. 49-54.

2 En una entrevista a Leonora Carrington, publicada en «México su apuesta por la cultura», le preguntaron: «¿Qué extraña de aquella época? Extraño a Remedios. Era muy inteligente. Nos conocimos en París, en una reunión llena de gente. Aquí nos volvimos a encontrar», A. Ponce (coord.), «Leonora Carrington: El mundo es enormemente misterioso», en México su apuesta por la cultura, México, Grijalbo, 2003, p. 75 .

${ }^{23} \mathrm{~J}$. Kaplan, Viajes inesperados..., op. cit., p. 93.

LECTURA Y SIGNO, 4 (2009), pp. 141-159 
entre otras; ${ }^{24}$ aunque los ingresos económicos más estables de Varo procedían de los dibujos publicitarios de la casa Bayer. ${ }^{25}$ Benjamin Péret, por su parte, trabajaba como traductor y profesor de francés. ${ }^{26}$ En 1947, Varo y Péret decidieron separarse «Péret regresó a Francia y Varo se mudó a vivir por algún tiempo, en la misma ciudad de México, a la casa de sus amigos José y Kati Horna ${ }^{27}$. Este mismo año Varo se marchó a Venezuela, en compañía del piloto francés Jean Nicolle, ${ }^{28}$ para encontrarse con su madre, su hermano Rodrigo y la familia de éste. En ese país permaneció hasta principios de 1949, momento en que decidió regresar a tierras mexicanas para establecerse definitivamente. Años más tarde, en 1952, Varo se unió con Walter Gruen. $^{29}$

Es a partir de este momento y hasta su muerte en el año de 1963, cuando Varo decidió concentrarse en sus labores artísticas. Durante este tiempo participó exitosamente en diversas exposiciones y muestras de pintura. Adicionalmente, hizo públicos algunos textos autógrafos que muestran, como característica común, su vinculación con algún otro lenguaje artístico. A pesar de que cada uno de estos escritos fueron redactados en fechas y según propósitos diversos se mantiene como constante que su autora aglutinó, como un todo, los lenguajes utilizados

${ }^{24}$ W. Gruen, y R. Ovalle, Remedios Varo..., op. cit., p. 45.

25 Esta etapa, como la época de París en la primavera de 1937, resulta muy interesante por la diversidad de labores creativas que Varo pone en práctica. Si anteriormente se destacaba su experimentación con diferentes técnicas pictoricas, en esta ocasión llama la atención la variedad en sus ocupaciones. De estas, debe señalarse este primer acercamiento de Varo hacia el espectáculo teatral con el diseño del vestuario para un ballet, lo que sin duda apunta hacia la obra de teatro que más tarde escribiría junto a Carrington, así como a su participación en el diseño de las máscaras para la puesta en escena del auto sacramental El gran teatro del mundo, dirigida por Álvaro Custodio en 1958. ${ }^{26} \mathrm{R}$. Tibol, Diversidades en el arte del siglo XX. Para recordar lo recordado, México, Universidad Autónoma de Sinaloa, 2001, p. 120.

27 José Horna, escultor español que Varo había conocido en la Academia de Madrid, y su esposa la fotógrafa húngara, Kati Horna. Véase la semblanza realizada por A. Sánchez Mejorada, «Kati Horna: una mirada insólita y cotidiana», Cuartoscuro. 50 (sep.-oct., 2001)

http:// www.cuartoscuro.com/50/articulos/html

${ }^{28}$ A decir de Kati Horna, Jean Nicolle «era un hombre carismático para las mujeres, tan simpático, con todos sus planes, bromas y juegos que atrajo la atención de Varo»; en J. Kaplan, Viajes inesperados... op. cit., p. 111.

${ }^{29}$ W. Gruen, y R. Ovalle, Remedios Varo..., op. cit., p 46. en los campos de concentración franceses. Su cotejo, como muestras representativas de la degradación moral española de la época, es más que recomendable.

No podemos establecer tampoco con exactitud la fecha en que ambos escritores retoman su vieja amistad tras la guerra. El primer indicio de sus contactos es un texto publicado por Max Aub en su revista Sala de espera publicación señera del exilio, concebida, financiada y escrita por el valenciano, que en su número 22 de 1950 editaba un retrato poético, titulado "Dámaso Alonso", donde se perfilan algunas de las claves de su nueva relación tras la guerra. Mucho más interesante, sin embargo, resulta otro texto de Sala de Espera, la "Carta abierta a Dámaso Alonso", fechada el uno de julio de 1950 y aparecida en el número 23. Max Aub pone sobre la mesa el hecho de que Alonso decida quedarse en España arrinconado, oscuramente dedicado a la exégesis literaria, quejándose ambiguamente, protestando sólo en la sombra contra la injusticia, el horror y la miseria del mundo (contenidos que Aub no duda en identificar directamente con el franquismo), en clara referencia a sus Hijos de la ira. El texto sobrescribe, en concreto, un artículo del académico aparecido en Cuadernos Hispanoamericanos (Sept. - Dic., 1949), "La Rueca de Villaespesa”, donde Alonso se detiene en analizar "la rueca" (el objeto y la palabra) en los poetas modernistas. En un tono decididamente emotivo, pero duro, Max Aub comenta al respecto:

El régimen bajo el que vives, por tu gusto, impide mayores vuelos, y, de más a menos, viniste a considerar, en tus espléndidos ensayos, esas virguerías estilísticas como fundamentales, tal vez sin darte cuenta de tu renuncia. [...] Queréis convertir la literatura en ciencia, como si la retórica fuese anterior a la obra, de la misma manera que los cálculos los son a lo visto en ciertas disciplinas científicas. Esa crítica tan ínfima y gazmona, tan especializada para especialistas ¿qué es frente a la obra de arte? [...] Cierto es que la inconformidad con el régimen os lleva a apartaros del comercio humano y fomenta un sentimiento de soledad y pesimismo. Confinado en tu rincón te dedicas a roer el queso que te dejan. [...] Abandona ya tus encabalgamientos, y vuelve al sentido Perdiéndote en lo ínfimo te empequeñeces, y basta con otro Alonso [se refiere a Amado] perdido. Fraternalmente tuyo. M. A.

Tras esta publicación, sus contactos hubieron de hacerse frecuentes en un punto inconcreto entre 1951 y 1954. En carta de este último año, la primera 
y gestiona las representaciones que se llevan a cabo tanto en los frentes como en la retaguardia republicana.

Esa diferencia esencial entre los dos amigos determinará toda su vida posterior. De hecho, cuando se reanuden sus relaciones epistolares tras la derrota de 1939, las distancias entre sus experiencias vitales respectivas serán ya insalvables: mientras Dámaso Alonso regresaba oscuramente a su cátedra de Filología Románica en la Universidad de Madrid, cargo que desempeñaría hasta su muerte, Aub pasaba a Francia a un exilio que sería definitivo. Allí, acusado de judío y comunista falsamente - pues era ateo y militante socialista-, las autoridades fascistas de Vichy inician en 1940 una investigación contra Aub que culmina con su detención en la ciudad de Niza - donde pudo haber colaborado con la resistencia- y su reclusión en varias cárceles y campos de concentración (Roland Garros en París, Vernet en los Pirineos y Djelfa en la entonces Argelia francesa). Su evasión milagrosa del campo argelino le conduce en 1942 a Casablanca, donde se refugia varios meses de la policía marroquí (que ha decretado su busca y captura), hasta poder embarcar, finalmente, a México en 1943, país donde residirá hasta su fallecimiento.

Las distancias que separan a ambos autores se hacen ver claramente en el año 1944, cuando los dos amigos publican dos libros excepcionales: Hijos de la ira en Madrid, por un lado, y Diario de Djelfa en México, por otro. Textos roncos, desgarradores, extraordinariamente violentos y muy emocionantes, ambos ofrecen la posibilidad de valorar las rupturas (tanto históricas como emocionales) que ha ocasionado la Guerra Civil en la sociedad española de mediados de los años cuarenta, si bien, desde dos ángulos muy diferentes: el de Alonso, un texto simbolista en esencia, un universo íntimo, existencial, muy atormentado y básicamente religioso, dando forma a sentimientos desbordantes de angustia, aislamiento y soledad; el de Max Aub, por el contrario, un texto realista, un testimonio estremecedor de las experiencias verdaderamente límite a las que se vio arrastrado presentándolos como unidad significativa, es decir, como constructos creativos (Ver Tabla 1).

Tabla 1. Constructos creativos.

\begin{tabular}{lll}
\hline $\begin{array}{l}\text { Fecha de } \\
\text { redacción }\end{array}$ & \multicolumn{1}{c}{$\begin{array}{c}\text { Textos autógrafos que hizo públicos } \\
\text { Remedios Varo }\end{array}$} & Constructo creativo \\
\hline 1952 & Nota a Juan Soriano, escrito al reverso de dibujo & Escrito+Dibujo \\
$1955-1961$ & $\begin{array}{l}\text { Notas a Rodrigo Varo, escritas al reverso de } \\
\text { fotografías de sus pinturas }\end{array}$ & Escrito+Fotografías \\
1959 & De Homo Rodans & Escrito+Escultura \\
1960 & El caballero Casildo Martín de Vilboa & Escrito+ Retrato \\
\hline
\end{tabular}

El dibujo, las fotografías de sus cuadros, la escultura, la pintura y el escrito correspondiente a cada uno de estos medios artísticos, integran lo que se ha considerado como «constructos creativos» en los cuales la sinergia producida enriquece el sentido que las obras presentarían de encontrarse aisladas.

El primero de ellos corresponde al constructo realizado como un regalo para e pintor y escultor mexicano Juan Soriano (1920-2006). Se integra por el dibujo y la nota escrita al reverso de éste, fechado en el año de $1952 .{ }^{30}$ El Retrato del Barón Ángelo Milfastos de niño tiene un formato pequeño, mide $12.2 \times 15 \mathrm{~cm}$., fue realizado con tinta sobre papel. ${ }^{31} \mathrm{Su}$ destinatario comentaría años más tarde: «[Remedios] me hacía dibujos de historias que le contaba sobre mi familia».32 A través del escrito Varo atribuye al sencillo dibujo un valor que va más allá de sus cualidades estéticas «No te importe - le dice - que este dibujo sea tan malo, porque es un documento de gran valor histórico. Se trata del único retrato que existe del barón Ángelo Milfastos

\footnotetext{
${ }^{30}$ J. Kaplan, Viajes inesperados..., op. cit., p. 136.

${ }^{31}$ W. Gruen, y R. Ovalle, Remedios Varo..., op. cit., p. 254

${ }^{32}$ Comentario de Juan Soriano en una entrevista realizada en el 2003 por Columba Vértiz.
}

LECTURA Y SIGNO, 4 (2009), pp. 141-159 
cuando era niño»33. Con el texto la autora revela la «verdadera» historia del personaje central, quien, por cortar las cabezas de sus tías, moriría en la horca. Otro aspecto que cabe mencionar es que alude a un tópico, que será recurrente en la obra pictórica y escrita de Varo posterior a esta nota, relacionado con la invención tecnológica, el cual es presentado bajo una perspectiva irónica.

Asimismo entre los años comprendidos entre 1955 y 1961, Remedios Varo envió fotografías de sus cuadros a su hermano Rodrigo, y en su reverso anotaba algún comentario explicativo de la pintura. Al igual que la nota a Juan Soriano, la génesis de estos textos obliga, inicialmente, a considerar el soporte-papel utilizado que se limitaba a un espacio en blanco equivalente a una postal (aproximadamente $10 \mathrm{~cm} . \times 15 \mathrm{~cm}$.), estas dimensiones sugieren, inicialmente, que la extensión del texto se supeditaba a las medidas del papel utilizado, lo que se constata en la mayoría de estos escritos que están por debajo de las 200 palabras. A pesar de este limitante material, es posible considerarlos como una nueva forma de narración, originada en la descripción-interpretación de la pintura, que presenta cualidades estéticas propias al ocuparse de la simbología, los espacios, los personajes y las acciones presentadas. Estos textos muestran una serie de rasgos característicos presentes en el resto de la producción escrita de Varo.

En los constructos integrados por las fotografías de los cuadros y las notas escritas al reverso parecería que la imagen pictórica es más elocuente que lo anotado al reverso de la fotografía de ésta, pero al leer el escrito se amplía la percepción de los detalles y se incrementa la comprensión de los símbolos de la imagen. Sin embargo, incluso apoyándonos en ambos lenguajes aún quedan elementos silenciados y algunos más, un tanto ambiguos. Los constructos creativos de Remedios Varo,

33 Véase la edición crítica en E. Mendoza Bolio, A veces escribo como si trazase un boceto. Los escritos de Remedios Varo, Tesis de Doctorado inédita. México, Instituto Tecnológico de Monterrey, 2008, pp. 187-188 y pp. 273-276, en su edición genética que muestra diferentes etapas del proceso de creación de este texto. eclécticas, por lo silenciosa, y en ese sentido puede ser tomada por una de las menos comprometidas del grupo. Inmerso en su universo erudito jamás se manifestó, públicamente al menos, en ninguna dirección. El caso de Max Aub, sin embargo, es netamente diferente; sabemos que el escritor estaba afiliado al Partido Socialista Obrero Español desde 1929 y que se destacó muy pronto en actividades políticas. Lo encontramos, por ejemplo, en la Aliança d'Intellectuals per a Defensa de la Cultura de Valencia como socio fundador con carné número 3; impartiendo conferencias en la Casa del Pueblo de Madrid ("La guerra y el socialismo", aparecida en el periódico El Socialista) o escribiendo artículos contra la amenaza fascista ("Sobre algunos mitos fascistas" en la revista Nueva Cultura de Valencia), en una línea densamente militante.

Es así que, llegado el 18 de julio de 1936, las respectivas vidas de los dos amigos reflejan experiencias distintas. No hay muchos datos acerca de cómo Dámaso Alonso pasó la guerra. Conocemos apenas su participación en el Consejo de colaboración, así llamado, de la revista Hora de España (subtitulada "Ensayos. Poesía. Crítica. Al servicio de la causa popular"), donde en 1937 firma un texto en torno al tema de la injusticia social en la literatura española. Carecemos de más noticias. Por el contrario, atendiendo al caso de Max Aub, encontramos a un hombre que se identifica plenamente con la causa republicana y que responde implicándose de lleno en los acontecimientos: además de sus obras dramáticas llamadas "de circunstancias", creadas en el contexto de la guerra, Aub organiza representaciones itinerantes con su grupo de teatro "El búho" dentro del programa cultural republicano; pasa pronto a dirigir junto con el pintor comunista Josep Renau el periódico de unificación Verdad de Valencia; en 1938, es reclamado por el embajador en París, su amigo Luis Araquistáin, para ocupar allí el cargo de agregado cultural; a su regreso a Madrid, ocupa el puesto de secretario en el Consejo Central de Teatro, presidido por Antonio Machado, desde donde prepara algunas ediciones populares 
Fue Madrid, con toda seguridad, el escenario en el que ambos se conocieron. Los dos frecuentaban, por ejemplo, la Residencia de estudiantes y su tertulia, llamada de "los chopos", donde coincidían con otros jóvenes internos como Federico García Lorca, Pepín Bello, Dalí, Luis Buñuel, Emilio Prados o José Moreno Villa, entre otros, con quienes colaboraban a menudo en las múltiples actividades patrocinadas por la institución. Igualmente, ambos estuvieron vinculados al círculo ultraísta madrileño, reunido un tiempo en torno a la figura de Rafael Cansinos-Assens, a su tertulia del Café Colonial y a la revista Horizonte, fundada por Pedro Garfias, José Rivas Panedas y Juan Chabás. Sabemos también que los dos escritores eran clientes habituales de la librería de León Sánchez Cuesta, en el número 4 de la Calle Mayor de Madrid, el establecimiento mejor surtido del momento, (donde entonces trabajaba como contable Luis Cernuda), también entre otros muchos posibles lugares donde hubo de concretarse, sin duda, su relación

Al margen del traslado de Dámaso Alonso en 1933 a la Universidad de Valencia, ciudad en la que reside Max Aub (casado allí desde 1926 y donde residirá hasta su exilio en 1939), para tomar posesión de su cátedra de Filología Románica -hecho que hubo de acercar a los amigos más estrechamente y facilitar sus vínculos-, los años treinta sitúan a ambos, sobre todo, ante un contexto histórico convulso que determinará definitivamente sus vidas. La llegada de la Segunda República señala, en este mismo sentido, un hecho extraordinariamente representativo y vigoroso desde el punto de vista socio-cultural para aclarar las relaciones posteriores entre ambos autores. Fue el tiempo en que todos los integrantes de la generación -fuera cual fuera su orientación política- maduran adquieren perspectiva con respecto a ellos mismos y a sus experiencias, obligándose a un replanteamiento de su personalidad como escritores, y como ciudadanos también, en el ámbito de lo público.

Diremos, de entrada, que no existen testimonios sobre Dámaso Alonso que lo relacionen nunca con lo político; el académico representa una de las posiciones más parafraseando a Guigon, ${ }^{34}$ quiebran nuestras costumbres visuales e intelectuales pues su apreciación obliga a realizar una lectura que vaya de la pintura hacia el texto y viceversa, proceso que implica una profunda observación.

En medio de su creciente éxito como pintora, en el año de 1959, Remedios Varo realizó la escultura Homo Rodans y redactó un texto que tituló De Homo Rodans, escrito a mano, en 10 folios tamaño carta, sin numerar. Con éste inauguraba públicamente su faceta como escritora. De Homo Rodans se considera su primer escrito público con destino comercial, el cual, al igual que la escultura, forma parte de una colección privada.

Remedios Varo, en una carta dirigida a su madre fechada en el mismo 1959, hace alusión acerca de De Homo Rodans:

Eso de la figurita que dicen es una cosa que no te había contado porque no sabía bien cómo explicártelo, ya que se trata de antropología y no de pintura. Resulta que hice con huesos de pescuezo de pollo y de pavo, después de limpiarlos muy bien, una figura, y escribí un pequeño tratado de antropología (imitando un viejo manuscrito) para demostrar que el antecesor del homo sapiens fue esa figurita que hice, a la que llamo hom rodans (porque termina en rueda). Se me ocurrió llevar el manuscrito y la figurita a la librería de un amigo, y resulta que vino un señor, lo vio y le encantó y le hizo mucha gracia (todo está hecho y escrito en broma). Este señor, que resultó ser secretario de un ministro, fue a buscar al ministro, lo llevó a la librería, y tanto le gustaron la figura y el manuscrito que los compró, nada menos que para ofrecérselo como regalo de Navidad a presidente de la República. Ya te puedes figurar que me quedé pasmada. No te doy detalles de lo que escribí o de la figura, pues todo está hecho imitando las cosas y palabras científicas que casi nadie entiende y muchas partes del escrito están en un latín inventado que ni yo misma entiendo, pero el conjunto resultaba gracioso..$^{35}$

Remedios Varo parece mostrarse gratamente sorprendida por la acogida de este proyecto escultórico-literario, que había elaborado a manera de parodia de un discurso científico, que ella misma define como «un pequeño tratado de

${ }^{4}$ E. Guigon, «Imágenes y textos en la obra de Remedios Varo», en Remedios Varo, Arte y Literatura Teruel, Museo Teruel, 1991, pp. 15-22. Particularmente, al considerar que «Remedios parece no haberse podido limitar a un único modo de expresión. Para ella los medios del pintor y los del escrito son solidarios en el quebrantamiento de nuestras costumbres visuales e intelectuales», p. 17.

${ }^{35}$ B. Varo, Beatriz, Remedios Varo..., op. cit., pp. 227-228

LECTURA Y SIGNO, 4 (2009), pp. 141-159 
antropología», aunque aclaraba que «imitaba un viejo manuscrito» y que todo estaba «hecho y escrito en broma». Como se lee en el fragmento siguiente:

El endurecimiento cobra cada día más prestigio: músculos duros, carácter inflexible, ejercicios destinados a endurecer las superficies y volúmenes anatómicos femeninos, etc. Esta tendencia hacia el endurecimiento ya era notable en la época de Quintiliano, quien nos relata en sus Narraciones Tórbidas:

"...et procer venerabile et vetustus caminandum naturæ vislumbratum virgo impúdica virgo tórbida et ornata duobus globis durissimos et homo vetustus appetitum venere ardencens luxuria et sudore suæ atque recondidit membra simulacris voluptatem consumatum est".

La unánime tendencia hacia el endurecimiento - mejor que tendencia, el anhelo, diría yo - que reinó durante la Primera Actitud o el Primer Movimiento, como tan acertadamente lo llama Jean Fraçois de la Croupiette, ¿qué es sino el irrefrenable deseo de trascender que anima a todas y cada una de las cosas? Deseo quizás inconsciente y desordenado, pero no por eso menos tenaz y peligroso, ya que tenemos muchos ejemplos de los terribles resultados del reblandecimiento trascendental de los abismos minerales cuando éstos comenzaron a retroceder en su equivocado y audaz camino hacia la dureza absoluta. ${ }^{36}$

Con este constructo creativo que considera un «conjunto [que] resultaba gracioso» continuaba con la práctica de crear dos objetos artísticos cuya complementariedad los enriquecía. La escultura, elaborada con huesos de pollo y pavo, ${ }^{37}$ y el escrito que había realizado eran para Varo una parodia lúdica, lo que podría explicar su «pasmo» ante la buena acogida. Quizá la inusitada aceptación en el mercado del arte de este objeto surrealista contribuyó a que Remedios Varo conservara diversos escritos en sus cuadernos.

Finalmente, se encuentra el constructo de El caballero Casildo Martín de Vilboa ${ }^{38}$ que se integra por el escrito redactado en tres cuartillas manuscritas e ilustrado con un dibujo, a manera de un emblema heráldico, que encabeza la carátula; y la obra

36 E. Mendoza Bolio, A veces escribo..., op. cit., p. 182.

37 Wolfgang Paalen, otro de los amigos surrealistas de Varo, utilizó también huesos de pollo en la escultura El genio de las especies realizada en 1938, reproducida en J. Kaplan, Viajes inesperados..., op. cit., p. 258.

${ }_{38}$ El texto íntegro de El caballero Casildo Martín de Vilboa, se incluye en E. Mendoza Bolio, A veces escribo..., op.cit., pp. 187-188, en edición crítica, y pp. 273-276, en la edición genética que muestran etapas diferentes del proceso de creación del mismo. monumental trabajo filológico en torno a los clásicos —su mítica edición de las Soledades de 1927, acompañada de una paráfrasis todavía sin superar; o con su trabajo magistral La lengua poética de Góngora que publicará en 1935- y a la Historia de la Lengua, por ejemplo.

Por el contrario, Max Aub jamás obtuvo ningún título universitario. Llegado a Valencia en los alrededores de 1914-1915 desde París —donde nació-, huyendo de la Gran Guerra por el origen judío de su familia, Aub abandona definitivamente los estudios tras el bachiller y entra a trabajar en el negocio familiar como viajante comercial de bisutería fina para caballeros. Su temprana afición por el arte y los libros, se desarrolla y se completa, en su caso, fuera del radio erudito y siempre desde la vertiente más humana. Max Aub entabla pronto relaciones con otros jóvenes valencianos (José Gaos, José Medina Echeverría, Genaro Lahuerta, Pedro de Valencia, Vicente Llorens, Juan Gil-Albert o Fernando Dicenta) con los que introduce las vanguardias en la ciudad mediterránea, así como con una multitud de grupos de provincias, normalmente agrupados en torno a alguna revista o tertulia, con los que mantiene frecuentes contactos durante sus viajes de negocios: la revista Alfar de Coruña y su director Julio Casal; Azor y Hélix de Barcelona; Carmen de Gijón, dirigida por Gerardo Diego; o la tertulia literaria de Mourlane Michelena y Manuel de la Sota y Sotomonte en Bilbao, dando a conocerse y a conocer los frutos de su obra poética, teatral y narrativa del momento, en una línea, en general, esencialmente vanguardista (la colección Los poemas cotidianos; las piezas El celoso y su enamorada, Espejo de avaricia, Narciso, El desconfiado prodigioso; sus relatos Caja, Geografía o Fábula Verde; o las novelas Luis Álvarez Petreña y Yo vivo ya en plena evolución hacia el realismo). Con todo, sus amistades decisivas se concretan especialmente en Madrid. Allí, en los alrededores del año 1923, conoce a Enrique Díez-Canedo y a los integrantes de la muy notable tertulia del Café Regina, frecuentada por figuras como Ramón María del Valle-Inclán, Manuel Azaña, Luis Araquistáin, Cipriano Rivas Cherif, Paulino Massip, León Felipe o Pedro Salinas, donde quedará ya integrado. 
dirigido al amigo con ocasión de la publicación de su libro Hombre y Dios, aparecido en España en 1955. No fue, y conviene insistir en ello, un texto pensado para ser hecho público nunca. Sin embargo, la proyección cultural de ambos escritores, así como la altura inequívoca de los referentes a los que se alude, hacen interesante una valoración histórica del inédito, muy útil para comprender los términos de la compleja relación que ambos mantienen en el tiempo.

Desconocemos a día de hoy la fecha y las circunstancias exactas en las que surgió la amistad entre Dámaso Alonso y Max Aub; de hecho, no hay ningún documento que la acredite. Los materiales conservados al respecto son todos posteriores a la Guerra Civil (diarios, memorias, correspondencia), con lo que no pueden establecerse con garantías sus detalles. En todo caso, sabemos que fue en Madrid y durante aquel periodo mítico de la Edad de Plata - el que transcurre entre la dictadura del general Miguel Primo de Rivera y la Segunda República españolacuando se forja y se consolida su relación. Una relación ésa especialmente llamativa, por cuanto los perfiles de ambos escritores difieren de una manera sobresaliente.

Licenciado en las carreras de Derecho y Filosofía y Letras, discípulo y colaborador de Ramón Menéndez Pidal en el Centro de Estudios Históricos de Madrid, profesor ya en los años veinte en las Universidades de Berlín, Oxford, Cambridge, la Stanford University de California, el Hunter College y el Columbia University de Nueva York, Dámaso Alonso es, sin duda, el autor más académico -entiéndase bien el término- de la llamada Generación de la República (o del 27). De hecho, Dámaso Alonso siempre se percibió a sí mismo acompañando a la Generación como crítico, y no como creador. Su obra poética, en rigor, y muy especialmente en la anteguerra, ocupa un lugar menor -apenas dos libros, Poemas puros, poemillas de la ciudad (1921) y El viento y el verso (1925), además de un puñado de piezas publicadas en la revista Índice, donde se da a conocer junto a otros escritores como Jorge Guillén, Antonio Espina, Pedro Salinas o Carmen Conde; y en la revista Litoral de Málaga, dirigida por Emilio Prados y Manuel Altolaguirre-, si es comparada, al menos, con su pictórica Retrato de Juan Martín datada en 1960. ${ }^{39}$ Éste lo realizó Varo para regalárselo a Juan Martín, dueño de la galería de arte que comercializó algunas de sus obras. En el relato hace una reseña de la peculiar labor espiritual de Casildo Martín de Vilboa en el año de 1462:

Hallábase entonces el reino de Vilboa en un estado de gran disipación y herejía y sus habitantes dejaban pasar hasta 3 y hasta 4 horas sin recitar oración alguna. Este estado de cosas hacía que la "Espiral Sonora de la Oración" no llegase al cielo con regularidad provocando por lo tanto muchos disturbios atmosféricos y tempestades. Pero llegado que hubo el gran ornitólogo con sus búhos orantes y habiéndolos distribuido por toda la región, subió de nuevo una gran Espiral en forma muy regular y mejoró no sólo el tiempo, sino que, avergonzados los vilbohítas, tomaron ejemplo de las aves y recuperaron su alto nivel espiritual.

Como ya se ha dicho, la pintura y el texto, como un todo creativo, se cargan de significado y, al mismo tiempo, cada uno de manera independiente posee atributos particulares. La apariencia de arcaísmo es la característica evidente en ambas creaciones: en la pintura utiliza el craquelado, técnica que permite dar al óleo un aspecto antiguo y envejecido, al reproducir finas grietas imitando aquellas que se forman a menudo en la superficie de viejas pinturas ajadas por el paso del tiempo. Por lo que respecta a la versión final del escrito, Varo imitó la apariencia de un manuscrito antiguo pues con la caligrafía lograba armonizarlo con el retrato al que hace referencia. Es sabido que a Varo «no le gustaba nada pintar retratos», ${ }^{40}$ por lo tanto, se puede afirmar que le interesaba, más que el retrato o el texto en sí mismos, el juego ficcional que implicaba su elaboración, combinando, una vez más, la escritura y la pintura.

A través de la reflexión sobre los constructos creativos, se aprecia la fuerza polisémica que poseen y la forma en que la silenciosa reciprocidad de los lenguajes utilizados los potencia logrando que de éstos se desprendan diversas lecturas. Resulta evidente que Varo buscaba hacer reír, pero no sólo eso, utilizaba la ironía ${ }^{39}$ Según ficha técnica de la pintura en W. Gruen, y R. Ovalle, Remedios Varo..., op. cit., p. 298.
${ }^{40}$ J. Kaplan, Viajes inesperados..., op. cit., p. 135.

LECTURA Y SIGNO, 4 (2009), pp. 141-159 
como un subterfugio para entablar un diálogo con su lector al que le exigía una profunda mirada. De tal suerte que se podría considerar que, para aventurarse a la interpretación de los constructos creativos de Varo, no se trata solamente, parafraseando a Gadamer41, de recoger la información transmitida y correr impacientes a la búsqueda del sentido final, sino de que una vez rebasado ese primer nivel de comprensión, los constructos creativos inciten entonces a averiguar, a revelar los posibles significados ocultos; a avanzar hacia un nivel más íntimo, pues su categoría sugiere que encontrar ese sentido final implica una interpretación más honda, ya que transmiten un mensaje que va más allá de sus lenguajes por los pensamientos que provocan. Sin embargo hay que considerar que «lo que es, nunca se puede comprender del todo», ${ }^{42}$ de ahí la riqueza de la experiencia con el arte.

Además de los constructos creativos antes mencionados, entre el acervo escrito de Varo se encuentran los manuscritos autógrafos conservados en sus cuadernos personales ${ }^{43}$. Estos textos presentan, en su mayoría, una caligrafía legible, sin enmiendas o tachaduras. Su datación, aunque difícil de precisar, se puede ubicar entre 1941 y 1963, período de tiempo que abarca los años que Varo vivió en la ciudad de México. No obstante, algunos escritos presentan marcas que, al relacionarlas con su obra pictórica o con su biografía, permiten vislumbrar alguna fecha de su redacción. En este conjunto se encuentran relatos de sueños, narraciones y cartas.

Los relatos oníricos, ${ }^{44}$ escritos de vigilia procedentes del mundo de lo soñado, permitían a Varo «transportar los hechos hasta la conciencia» 45 y salvarlos del olvido

${ }^{41}$ H. G. Gadamer, «Texto e interpretación», En Verdad y Método II, Salamanca, Sígueme, 1992, p. 344, señala: «En ellos [los textos literarios] no se trata simplemente de recoger la información transmitida por el texto. No corremos impacientes, directamente a la búsqueda del sentido final para captar con él la totalidad de la comunicación

42 Ibidem, p. 323.

${ }^{33}$ Los textos se incluyen en Mendoza Bolio, Edith. A veces escribo..., op. cit. pp. 190-222.

44 "Biografías nocturnas" a decir de Ll. Duch, Mito, interpretación y cultura. Aproximación a la logomítica

Barcelona, Herder, 2002, p. 27, n. 3.

${ }^{45}$ C. Jung, Realidad del alma, Buenos Aires, Losada, 1957, p. 63.

\section{NOTAS A UN TEXTO INÉDITO DE MAX AUB: SU COMENTARIO A HOMBRE} Y DIOS DE DÁMASO ALONSO (1955)*

\author{
PabLo CARRIEDO CASTRO \\ Universidad de Washington
}

El presente inédito fue encontrado en el Archivo de la Fundación Max Aub de Segorbe, donde se atesora hoy el legado impresionante que dejara el escritor valenciano para la posteridad, todavía hoy en vías de ser completamente restaurado y analizado. Quisiera agradecer al equipo humano de la Fundación, a su archivera y a los herederos legales del escritor, su inestimable ayuda y su amabilidad al permitir su publicación. El texto, en concreto, fue hallado entre la correspondencia dirigida a su amigo Dámaso Alonso; se trata, por lo tanto, de un texto informal, perteneciente al ámbito más privado de la vida de Max Aub; un comentario personal, escrito y

"Recibido: 18-03-2009 Aceptado: 28-04-2009 
al fijarlos en un texto. ${ }^{46}$ Como se puede apreciar en el siguiente fragmento de Plastilina:

Fui a visitar a Javier y Amaya y encontré también en su casa a sus padres. Al cabo de un rato me di cuenta con sorpresa que toda la familia parecía haber hecho una especie de descubrimiento nutritivo basado en un gran desarrollo espiritual que ellos habían alcanzado. Vi que todos ellos estaban trabajando con pedazos de plastilina dándole formas huecas, algo así como tacitas y cacerolitas que después podían comerse resultando altamente nutritivas.

Los personajes de este escrito, Javier, Amaya y los padres de éstos, formaban parte de la vida real de Varo, mientras que la situación que plantea el relato presenta un juego ficcional en el cual retoma un elemento recurrente en su obra, la vida cotidiana envuelta en un halo de magia y fantasía. En otros de sus relatos oníricos se puede percibir un claro paralelismo con algunas de sus obras pictóricas.

Asimismo en los cuadernos de Remedios Varo se encuentran escritos de mayor extensión ${ }^{47}$ en los que incluye, como elementos que configuran una historia más elaborada, algunos relatos de sueños como en Días de meditación y en Trigo, aceitunas y naranjas, presérvate del frío con lana de oveja. Dentro de la misma temática se inscribe también Recetas y consejos para ahuyentar los sueños inoportunos, el insomnio y los desiertos de arenas movedizas bajo la cama sin embargo éste apunta, por las inferencias textuales relativas a su formato, hacia un constructo creativo similar a los presentados anteriormente pues alude al estado físico en que se encuentra el volumen, lo cual lleva a pensar que Varo lo diseñaría como un libro antiguo y maltratado. El texto sigue la estructura de una receta de cocina que presenta en forma humorística e irónica.

Se toman los cuatro kilos de miel y se extienden con una espátula sobre las sábanas de la cama. Tómense las plumas de las gallinas y espárzanse sobre las sábanas embadurnada de miel. Tiéndase la cama con cuidado. (No es indispensable que las plumas sean blancas, pueden también usarse de color, pero hay que evitar las llamadas de gallina de

${ }^{46}$ María Zambrano señala: «No se escribe ciertamente por necesidades literarias, sino por necesidad que la vida tiene de expresarse»; La confesión: género literario, Madrid, Siruela, 2004, p. 25.

${ }_{47}$ Véase E. Mendoza Bolio, A veces escribo..., op. cit., pp. 201-217. 
Guinea pues éstas producen a veces un estado ninfomaníaco de larga duración o graves casos de priapismo).

Adicionalmente entre los textos que Varo no hizo públicos se encuentran dos escritos epistolares. La redacción de las misivas de Varo denota la clara intención de divertir a sus lectores para lo cual emplea diversas estrategias discursivas entre las que se pueden observar juegos de palabras y marcas que advierten la estrecha relación de amistad con los destinatarios y la complicidad existente entre ellos. Varo se escabullía entre la realidad y la ficción y hacía que los mensajes implícitos fueran muchos más que los explícitos: «Espero vuestras noticias y sólo entonces os comunicaré cómo fui visitada, tiempo ha, por una sirena hechicera, fervorosa admiradora vuestra y muy preocupada e intranquila a causa de vuestro retraimiento de la vida cotidiana. ¡Misterio!» A través de las alusiones fantásticas llenaba de comicidad su vida cotidiana, que se revelaba llena de matices, en ese intento de diálogo separado por el tiempo y el espacio.

Finalmente, entre los escritos recuperados de la obra de Varo, se encuentra el manuscrito de una pieza teatral realizada en colaboración con su amiga, la también pintora, Leonora Carrington. Es probable que éste haya sido escrito alrededor de 1947 y su creación mero divertimento. La intención lúdica es evidente, las autoras explícitamente declaran, en una nota preliminar, que la obra fue realizada «para diversión de los actores». En ese sentido, se explica que el reparto esté lleno de comicidad en sí mismo, particularmente por el deseo expreso de la simulación, los hombres representarían los personajes femeninos y viceversa. Desafortunadamente no nos ha sido posible saber si la obra llegó a representarse o si sólo fue escrita para ser leída entre sus amigos íntimos, ya que hasta el momento no se cuenta con ningún testimonio que lo confirme, pero dado que rompen con la relación tradicional entre
Mendoza Bolio, Edith y Farré VIDAL, Judith, «Pies en polvorosa. Travesía hacia México de Remedios Varo», en B. López y J. Farré (eds.), Viajes y viajeros, México, Instituto Tecnológico y de Estudios Superiores de Monterrey, 2006, pp. 209-224.

PACHECO, José Emilio, «La Batalla del Surrealismo (Octavio Paz y la Revista Estaciones)», en Peter G. Erle, G. Gullón (eds.), Surrealismo/Surrealismos. Latinoamérica y España, Philadelphia, University of Pennsylvania, 1975, pp. 49-54.

PAZ, Octavio, La búsqueda del comienzo (Escritos sobre el surrealismo), Madrid, Fundamentos, 1983

PONCE, Armando (coord.), «Leonora Carrington: El mundo es enormemente misterioso», México su apuesta por la cultura, México, Grijalbo, 2003.

SÁNCHez MejoradA, Alicia, «Kati Horna: una mirada insólita y cotidiana», Cuartoscuro. Vol. 50, sep.-oct., 2001.

http://www.cuartoscuro.com/50/articulos/html

SOMOLINOS P., Juan, El surrealismo en la pintura mexicana, México, Arte, 1973.

TiBOL, Raquel, Diversidades en el arte del siglo XX. Para recordar lo recordado, México, Universidad Autónoma de Sinaloa, 2001.

VARO, Beatriz, Remedios Varo: en el centro del microcosmos, Madrid, Fondo de Cultura Económica, 1990

VéRTIZ COLUMBA, «Juan Soriano: razones e ideas sobre el arte», Noticias de Oaxaca Núm. 10465, Jueves 16 de febrero de 2006. http:/ / www.noticiasoax.com.mx ZAMBRANO, María, La confesión: género literario, Madrid, Siruela, 2004. 


\section{BIBLIOGRAFÍA}

ARTAUD, Antonin, El teatro y su doble, Buenos Aires, Retórica Ediciones, 2002.

BRETON, André, Manifiestos del surrealismo, Buenos Aires, Argonauta, 2001.

CAstells, Isabel, Remedios Varo. Cartas, sueños y otros textos, México, Era, 1997.

CAWS, Mary Ann, Surrealism, Londres, Phaidon Press, 2004.

CIRLOT, Juan Eduardo, Diccionario de los Ismos, Madrid, Siruela, 2006.

Duch, Lluís, Mito, interpretación y cultura. Aproximación a la logomítica, Barcelona Herder, 2002

GADAMER, Hans-George, «Texto e interpretación», en Verdad y Método II, Salamanca, Sígueme, 1992.

Gruen, Walter y Ovalle, Ricardo, Remedios Varo. Catálogo razonado, México, Era, 1998.

GuIGON, Emmanuel, «Imágenes y textos en la obra de Remedios Varo», en Remedios

Varo. Arte y Literatura, Teruel, Museo Teruel, 1991, pp. 15-22.

HuizingA, Johan, Homo Ludens, Buenos Aires, Emecé Editores, 1957.

JuNG, Carl, Realidad del alma, Buenos Aires, Losada, 1957.

KAPLAN, Janet, Viajes inesperados. El arte y la vida de Remedios Varo, México, Walter Gruen/Era, 1998.

LIDA, Clara, Inmigración y exilio. Reflexiones sobre el caso español, México, Siglo XXI Editores/El Colegio de México, 1997.

MARÍN SILVESTRE, Dolors, «Remedios Varo incendiaria de la imaginación», Suplemento cultural de Solidaridad Obrera, No. 5, Verano 2000. (Encartado en el \# 297 del periódico Solidaridad Obrera)

http://www.soliobrera.org/pdefs/a5.pdf

MendozA Bolio, Edith, A veces escribo como si trazase un boceto. Los escritos de Remedios Varo, Tesis de Doctorado inédita, México, Instituto Tecnológico de Monterrey, 2008. los actores y el público al destacar que éste «es puro accidente» se ratifica el carácter privado de la posible representación de esta pieza teatral. ${ }^{48}$

$$
\text { [Acto I. Escena 1] }
$$

En el cráter del lejano y alto pico Oripipí, hogar de la reina Nesfatalina. Hartitos murciélagos, tecolotes, mariposas negras y otros ganados nocturnos deambulando por los lujosos departamentos de la Reina. Del suelo de lava arrugada suben plumas de humo. Se oyen gruñidos profundos de la misma barriga de la tierra. Entra Scatijeras con aspecto de conspirador, juega nerviosamente con su larga barba roja. Salen de aquella cascada de pelos colorados algunas moscas grandes; empieza a mirar atentamente un frasquito que tiene en la mano.

SCATIJERAS ¡Elíxir divino! ¡Aceite celestial! ¡Fruta mágica de mi inmenso saber ¡Oh, humanidad bestial, tiembla delante [de] este Santo Cuerpo Grasoso!

Entra el Perico verde humildemente.

PERICO ¡Oh, Scatijeras, emperador de la divina inteligencia, tira este aceite demoniacal!

SCATIJERAS Callado asqueroso pájaro, ¿qué sabes tú de mis invenciones divinas, cerebro de periquito en un cuerpo color de lechuga?

PERICO Gran Scatijeras, yo sé los poderes de esta pequeña botella: basta frotar las nalgas con el aceite para que el alma del humano salga visiblemente del cuerpo y los dos sigan viviendo cada uno por su lado.

SCATIJERAS ¡Cállate, Perico! ¡Oye la llegada de la Reina!

Aun cuando la obra teatral responde a lo que se considera como fantástico y humorístico, su temática está impregnada de símbolos y misterios religiosos heredados que, condicionados histórica y socialmente, remiten a universales míticos. Sin embargo, no se debe perder de vista el marco que la adscripción al surrealismo de las autoras conlleva. El trabajo de Varo y Carrington, dada su relación con «la realidad creacional de este movimiento»,49 apunta a encontrar en la "poética surrealista» algunas otras claves para profundizar en la interpretación de la pieza teatral. Una de estas marcas es la libertad para la creación. Varo y Carrington escribieron como si jugaran, haciendo con el juego un «intermezzo en la vida

${ }^{48}$ Véase la edición de la pieza teatral que se incluye en Ibidem, pp. 224-245, correspondientes a la edición crítica; en pp. 253-272, se incluye la edición genética de la pieza teatral, cuyo objetivo es presentar el texto lo más cercano posible al estado en que se encuentra para que sean las autoras y sus procesos los que se revelen. En ambas se ha introducido como título El Santo Cuerpo Grasoso.

${ }^{49}$ J. E. Cirlot, Diccionario de los Ismos, Madrid, Siruela, 2006, p. 638.

LECTURA Y SIGNO, 4 (2009), pp. 141-15 
cotidiana». ${ }^{50}$ De esta manera idearon un mundo posible, el «mundo de lo imaginario, esa tercera residencia del espíritu» ${ }^{51}$ al que Breton ya había hecho referencia en el Primer Manifiesto de los surrealistas:

El espíritu que se sumerge en el surrealismo revive con exaltación lo mejor de su infancia [...] De los recuerdos de la infancia y de algunos otros, se desprende un sentimiento de algo insumiso y al mismo tiempo descarriado, que considero lo más fecundo que existe. Quizás sea la infancia lo que está más cerca de la 'verdadera vida; [...] La infancia, en la que todo concurría a la posesión eficaz y sin restricciones de uno mismo. Gracias al surrealismo parece probable que retornen tales perspectivas..$^{22}$

Tanto Varo como Carrington muestran ese «impulso lúdico del espíritu» ${ }^{53}$ sumergido en el surrealismo y embebido quizá de los recuerdos de la infancia. Siguiendo a Artaud, se diría que con su escritura lograban apropiarse de aquello que todavía no era y lo traían a la existencia, ${ }^{54}$ tal como sucede en los juegos y que se manifiesta especialmente en el asunto central, la celebración del concurso que buscaba descubrir el alma más bella.

En conclusión cabe señalar que la comprensión del universo artístico de Remedios Varo será más amplia y profunda en la medida en que se consideren todas las huellas de su quehacer. El «constructo creativo» que es la obra total de Varo muestra la silenciosa reciprocidad de los lenguajes utilizados y la forma en que potencian su sentido. Varo rescata un cúmulo de imágenes y relatos que plasma tanto en los escritos como en las pinturas en los cuales el concepto de realidad

50 J. Huizinga, Homo Ludens, Buenos Aires, Emecé Editores, 1957, p. 16.

${ }^{51}$ J. E. Cirlot, Diccionario..., op. cit., p. 630.

52 A. Breton, Manifiestos del surrealismo, Buenos Aires, Argonauta, 2001, p. 60.

3 Huizinga en su reflexión acerca del «Papel de la figuración poética» en Homo Ludens señala: «El intento de aturdir la imaginación mediante una fantasía exorbitante, cuantitativa o cualitativamente, no opera sólo como función poética y en forma lírica. Esta necesidad por lo desmesurado es una típica función lúdica propia de los niños y la conocen también los perturbados mentales, lo mismo que ha sido algo grato para los elaboradores literarios de los mitos y las hagiografías. [...] Esta tendencia a producir un efecto sorprendente mediante la exageración desmesurada o mediante la proporción de todas las proporciones o relaciones, no debe ser considerada como algo totalmente serio [...] nos hallamos en presencia del mismo impulso lúdico del espíritu»; op. cit., p. 190

${ }^{54}$ A. Artaud, El teatro y su doble, Buenos Aires, Retórica Ediciones, 2002, p. 12 adquiere nuevas dimensiones en las que la lógica de la razón no corresponde a la lógica de la imaginación. 
poético erigiendo como mentor a Rodríguez Lesmes. Tras ellos vendrán Carlos Urueña, los hermanos del Mazo (Antonio y Mariano), Jesús Unciti, Luis Martín Santos Anderica, el pintor Ricardo Cesteros, el fotógrafo Florencio Domínguez y muchos otros deseosos de llenar y dotar de nueva vida la pobreza cultural del entorno.

Todo tal vez un tanto limitado, pero con una limitación, en cualquier caso, comprensible en la España de aquel momento. Conscientes de ello, en el editorial del número 1 de la revista Nubis. Silva de las ideas y de las letras (septiembre, 1946) ${ }^{7}$ invocarán a Ganivet para afirmar su vocación de universalidad desde la provincia sin caer en una dependencia excesiva de la capital. Por ello, su pretensión máxima será la de crear una revista plural, no excesivamente vinculada a lo local, una revista que aunará temas tan diversos como Filosofía, Historia, Arte, Ciencia y Poesía. En este último aspecto se buscará contactar con otros poetas del país. Carriedo lo hará con Crémer y Ory, dos de sus influencias básicas, y Fernández Nieto con los cordobeses del grupo «Cántico» de Pablo García Baena, tal y como consta en el acta de la asociación correspondiente al viernes, 24 de mayo de 1946.

En ese mismo número primero, en la «Pequeña historia de la Peña Nubis» 8 se puede encontrar un sucinto recorrido por los acontecimientos que marcaron hasta aquel momento la vida de la asociación. Allí se recuerda su fundación, el 7 de diciembre de 1945, en el Bar «La Reja» y la publicación de Sin primavera, de Fernández Nieto, con prólogo de Rodríguez Lesmes. También sus sonadas tertulias de fin de semana ${ }^{9}$ en las que se hablaba de los conceptos de clasicismo y modernismo, «la personalidad», «la figura de Rubén Darío», «el humor»; así como las actividades públicas, tales como los recitales en Radio Palencia o los «Sábados

\footnotetext{
${ }^{7}$ Nubis. Silva de las ideas y de las letras, 1 (septiembre, 1946). Texto sin firma publicado en la primera página.
8 Ibidem.

Aunque inicialmente se celebrarían los viernes, a juzgar por las fechas presentes en las actas observamos que también podían tener lugar en jueves o sábado. En muchas de ellas Fernández Nieto
} figura como «Heliodoro». lectura muy particular, a medio camino entre el análisis y lo creativo, envuelto todo en un tono muy amistoso y entusiasta, fuertemente tocado por la ironía (conviene recordar que Max Aub, ateo declarado, se sitúa ante un poemario de corte netamente religioso, lo que condiciona toda su lectura), dando cuenta de la amplitud de intereses, preocupaciones y aficiones comunes que ambos autores compartían, y donde vida y amistad, historia y literatura llegan a tocarse a una gran altura.

México, D. F., agosto 30 de 1955

\section{Sr. Don Dámaso Alonso \\ Colonia del Zarzal \\ San Martín de la Rosa, \\ Madrid, España.}

Al correr de los ojos, mientras que leía tu poema, después de haberlo dejado descansar diez días, he ido tomando unas notas, como si hubieses estado sentado enfrente de mí. Te las mando sin max ni más.

Recibí tu libro, tan precioso por dentro, con una portada que no le cuadra (¿no me publicaría un libro El Arroyo de los Ángeles?¹) cuando estábamos comiendo con Paco Ayala, ${ }^{2}$ lo abrí con el cuchillo de postre y nos lo tomamos con el café.

Tal vez no es un libro tan importante como tus $\underline{H i j o s}^{3}$ porque aquellos abarcan más, pero es un poema, sólo poema, perfectamente estructurado. Es tu libro más unido, más de una pieza, más resignado, tan blasfemo como los demás, y en tu obra, muy importante, porque sólo el contemplador faltaba. Ya no te falta, te miras a

${ }^{1}$ El Arroyo de los Ángeles. Editorial malagueña, que toma su nombre de una famosa calle de la ciudad, encargada de publicar Hombre y Dios en 1955

Francisco Ayala (1906-) escritor granadino. Implicado en la defensa de la República; tras la Guerra Civil se exilia en Argentina, Puerto Rico y Estados Unidos, país donde reside hasta 1976, cuando regresa definitivamente a España. La escena que describe Aub debe corresponderse con alguno de sus

${ }_{3}$ Hijojos de la Ira (Madrid, Revista de Occidente, 1944). Tercer y muy decisivo libro poético de Dámaso
Alcón. Alonso que vino a revolucionar el panorama poético español contemporáneo. 
ti mismo. Tú, el cáos [sic], a veces mundo nonato, otras en fárfara, otras hecho. Hecho, naturalmente, cuando ya te ves. Otros en tu caso se quedan tranquilos. Tú no. Sabes que te hiciste, pero ¿y si te hubiesen creado a tu pesar, sin tú saberlo? "Sólo el contemplador faltaba", el testigo, el testículo, el semen (que la coyunda es posterior, allí no hay problema gallina-huevo, todo es cuestión del último, plural).

Me da la impresión que tu poema, esa vena que te abriste, nació a la sombra de tus traducciones de Hopkings ${ }^{4}$ por eso es libro más "interior", más tuyo, más trágico (verás la referencia a Esquilo). Otro paréntesis: con tantas cosas como vemos y no vemos ¿estás seguro de que Hopkings escribió su "Consolación de la carroña" antes de que se la tradujeras? ${ }^{5}$ Lo dudo: la tradujiste primero y luego él la puso en cristiano-jesuita, en su vejez viruelera.

Nunca he sentido más no tenerte a mano para poder charlar cuando me venga en gana, tan solos como estamos y cada día más. He aquí un largo poema enconado -encoñado- en el hombre Dámaso. Te salió como una verruga o un cáncer. Los especialistas pronosticaron Dios, hiciste muchos análisis - con júbilo, con ansiedadtodos, ay, negativos. O lo que es lo mismo, todo resultaba Dios. "Llamadle como queráis". Tu libro no debe titularse

Dámaso Alonso

Hombre y Dios

sino Dámaso Alonso, hombre y Dios.

${ }^{4}$ Gerard Manley Hopkins (1844-1898), sacerdote jesuita y poeta británico muy admirado por Dámaso Alonso de quien tradujo varios poemas editados en el volumen Poetas españoles contemporáneos. "Seis poemas de Hopkins" (Madrid, Gredos, 1952). Es probable que el error en el nombre del poeta ("Hopkings”) se deba a la transcripción mecanográfica de la carta original (ver apéndice). El fallo resulta sorprendente en Max Aub que, en todo caso, lo cita correctamente en otros de sus ensayos y trabajos de esta misma época.

Poema titulado "Carrion Comfort" en el original, que abre su serie Sonetos de la desolación, fechada entre 1885-1886. Traducido por Alonso en "Seis poemas de Hopkins", Poetas españoles contemporáneos, Madrid, Gredos, 1952, p. 396.

\section{NUBIS, UNA PUBLICACIÓN HETERODOXA}

\subsection{Origen de la revista}

Es de suponer que, pese al aislamiento provinciano de Palencia, del que se lamentará Carriedo en carta a Crémer (fechada en esta ciudad el 5 de mayo de 1946) ${ }^{4}$ y de la falta de expectativas señalada alguna vez al recordar aquellos tiempos por Mariano del Mazo, ${ }^{5}$ los jóvenes de entre los que surgirá la iniciativa de Nubis, como revista y asociación, eran ávidos lectores de todas aquellas otras publicaciones en cuyas páginas se percibían con nitidez, en lo que a poesía se refiere, dos corrientes que, de algún modo, hundían sus raíces en la preguerra: una fundamentalmente clasicista, formal y temáticamente, y otra basada en un intento de rehumanización del arte poético, aunque marcada ahora por evidentes tintes expresionistas. Así, imbuida por el contagio de aquellas publicaciones, la revista Nubis vendrá a mostrarse de algún modo como un intento de dar forma corpórea a las inquietudes poéticas y culturales de este grupo de jóvenes palentinos que pretendían crear un órgano de expresión propio que fuese más allá de la oportunidad que desde 1941 les ofrecía el diario local en la sección «Literatura, ciencia, arte...»,6 dirigida por Dacio Rodríguez Lesmes.

A partir del impulso que supondrá esa sección y como consecuencia de las tertulias mantenidas en la rebotica de Fernández Rojo (calle Mayor, 38) durante el verano del 44, surgirá «Nubis», primero como «Peña» o asociación, luego como publicación homónima. Fernández Nieto, junto a un Gabino-Alejandro Carriedo recién llegado de la milicia y junto a Félix Buisán Citores, formará el núcleo inicial y

4e puede leer la carta completa en José Enrique Martínez, Victoriano Cremer. El hombre y el escritor León, Ayuntamiento de León, 1991, pp. 700-702

Mariano del Mazo, «De Gabino en tiempos de Nubis», El Norte de Castilla (30-XI-1991).

"Como señala Ayuso en un interesantísimo artículo que recoge la historia de la Peña «Nubis», la sección comenzaría a publicarse el 27-XI-1941, aunque no tendría entidad suficiente y continuidad hasta que se retomó el 11-IX-1942. César Augusto Ayuso, "Cultura y Literatura en Palencia en la primera década de posguerra", Publicaciones de la Institución Tello Téllez de Meneses [en adelante PITTM], 60 (1989), p. 637 
como ha señalado Leopoldo de Luis, «una sucesiva conquista de parcelas de libertad». ${ }^{1}$

Surgieron en un contexto delicado. Al aislamiento del país producido por el final de la guerra había que sumar la muerte o exilio (exterior o interior) de muchos intelectuales fundamentales en el período previo a la contienda. Por ello su presencia y proliferación podría calificarse como necesaria para cubrir aquella enorme ansia de libertad y para ir reconstruyendo desde la base, como ha dicho Juan Marichal, el pensamiento político e intelectual del país. ${ }^{2}$ También para tender un puente entre los poetas que permanecían en España y algunos de los no habían tenido otro remedio que exiliarse. Huelga recordar el papel fundamental que desempeñarán algunas tan señeras como Escorial (1940), Garcilaso (1943) o Espadaña (1944), sin olvidar, claro está, muchas otras como Lazarillo (1943), Proel (1944), Entregas de Poesía (1944) o la vallisoletana Halcón (1945), que en su número noveno publicaría por primera vez en España las hoy conocidísimas «Nanas de la cebolla» y otros poemas de Miguel Hernández. ${ }^{3}$

En este preciso contexto, pues, verán la luz Nubis y Rocamador y, a través de ambas, se desarrollará buena parte de la trayectoria vital y literaria de José María Fernández Nieto. ${ }^{1}$ Leopoldo de Luis, «Las revistas poéticas», en Fanny Rubio, Las revistas poéticas españolas, 1939-1975,
Alicante, Universidad de Alicante, 2004, p. 12.

2 Juan Marichal, «Modalidades del pensamiento político bajo la tiranía», El secreto de España, Madrid, Taurus, 1995, pp. 309-341.

${ }^{3}$ En las páginas centrales (8-9) del número noveno de Halcón (mayo, 1946) pueden leerse los poemas «Sepultura de la imaginación», «A la niña Rosa María», «Niño» y el soneto «Ascensión de la escoba». Junto a ellos, las «Nanas de la cebolla», aunque con el título de «Nana a mi niño».
Ahora otras cosas que deberían ser de otra carta. Me arruinas: no me mandas, como quedaste, los libros de Gredos ${ }^{6}$ - los que me pueden interesar- y los compro a ese cambio imposible que aquí imponen. ${ }^{7}$ Pero ¿por qué publicas libros tan rematadamente malos —entre tantos buenos- como el de Allison y Peers? ${ }^{8}$ ijijo, ese imbécil creía que las influencias dependen del número de traducciones, tan bruto el pobre que no podía suponer que Larra ${ }^{9}$ supiese francés o Alcalá Galeano ${ }^{10}$ inglés! ¡Y esa sutil distinción entre la revelación y el renacimiento románticos! Bueno, ese por lo menos se tomaba el trabajo de enterarse, a lo Lomba, ${ }^{11}$ pero enterarse, ipero lo que es Luis Alberto Sánchez!12 Te advierto que es una lástima porque desprestigia en parte la colección que se está vendiendo muy bien aquí.

${ }^{6}$ Gredos. Mítica editorial española fundada en 1944, especializada Filología y Estudios Clásicos. En 1950, Dámaso Alonso fundaba y pasaba a dirigir su Biblioteca Románica Hispánica, todavía hoy, referente indiscutible de la crítica en Lengua y Literatura españolas. Max Aub llegaría a publicar ahí una antología muy edulcorada para la censura en 1966, titulada Mis páginas mejores, que fue, sin embargo, severamente mutilada. Los pormenores de su edición pueden cha obra del profesor Manuel Aznar Soler Los laberintos del exilio. Diecinueve estudios sobre la obra literaria de Max Aub, Sevilla, Editorial Renacimiento, Biblioteca del exilio, 2003, p. 129.

Se refiere a los aranceles comerciales de aduana. Desde la Revolución de 1912, México mantuvo una politica oficial de proteccionismo con respecto a la importación extranjera para salvaguardar su "medios de regulación del comercio más que fuentes de ingreso tributario", "president Adolfo Ruiz Cortines. La situación que describe Max Aub tributario", en palabras de su presidente Adolfo Ruiz Cortines. La situación que describe Mán Aub se agrava, además, con la fuerte 12,50 ) frente a su par en dólares.
. 12,50) frente a su par en dólares.

Edgar Allison Peers (1891-1952). Pedagogo, traductor e hispanista británico. Escribió The history of the Romantic Movement in Spain, publicado en su primera edición en 1940. En España el libro fue lanzado póstumamente como Historia del movimiento romántico español, Madrid, Gredos, 1954, versión a la que se refiere Max Aub.

Mariano José de Larra (1809-1837). Escritor y periodista madrileño, especialmente conocido por sus artículos de costumbres en distintos rotativos de la prensa de la época; uno de los máximos exponentes del movimiento romántico español.

${ }^{10}$ Juan Valera y Alcalá Galeano (1842-1905), diplomático y escritor cordobés, autor entre otras novelas, de Pepita Jiménez y Juanita la larga.

${ }^{11}$ José Ramón Lomba y Pedraja, catedrático de Lengua y Literatura española en la Universidad de Murcia, nacido en 1868. Discípulo y albacea de Marcelino Menéndez Pelayo, amigo personal y colaborador de Ramón Menéndez Pidal; especialista en el Siglo de Oro y en el Romanticismo español

sobre los que realizó varias ediciones y estudios.
${ }^{12}$ Luis Alberto Sánchez (1900-1990). Político, crítico literario y escritor peruano. Max Aub debe referirse a su ensayo Proceso y contenido de la novela hispanoamericana publicado por Gredos en 1953.

LECTURA Y SIGNO, 4 (2009), pp. 161-188 
Posiblemente voy a escribir tres o cuatro artículos acerca de Otero, ${ }^{13}$ Nora, ${ }^{14}$ Celaya, ${ }^{15}$ Crémer, ${ }^{16}$ etc. (¿quién es Juan de Lecea, a quien tú citas ${ }^{17}$ y de quien no he leído nada?). ¿Quieres decirme a quién no debo olvidar? No olvides tú los pocos libros de que dispongo aquí. Lo que me interesa no son los poetas con tres estrellas (tal vez el único Otero) sino ese empuje norteño de la actual poesía joven española y su sentido político ¿quién es esa señora Ángela Figuera Aymerich ${ }^{18}$ ? Ayúdame.

Por correo ordinario te envío mis dos últimos libros, de cuentos. ${ }^{19}$ Ojala te parezcan bien. Como siempre, caerán en una poza. A ver quien los saca (los sacarán, Dámaso, cuando me muera. Entonces dirán: era un gran escritor. Lo que me hará una

${ }^{13}$ Blas de Otero (1916-1979). Poeta bilbaíno, máximo exponente de la llamada poesía social. Entra en contacto con Max Aub en el año 1956, cuando se fecha su primera carta.

${ }^{14}$ Eugenio de Nora (1923- ). Poeta y crítico literario nacido en León. Cofundador de la revista Espadaña, vanguardia de la nueva poesía de signo histórico y social de posguerra. Hizo una gran amistad con Max Aub en los alrededores de 1957, muy estrecha, en concreto, durante la confección de su estudio La novela española contemporánea ("lo bebí de cabo a rabo [le asegura Aub en 1959] dando gracias de que reivindiques a tanta buena gente"). ${ }_{15}$ Gabriel Celaya sobrenombre de Rafael Múgica (1911-1991), poeta nacido en Hernani, y el autor, tal vez, con el ascendente más poderoso sobre la poesía española de posguerra. Aunque Max Aub alude en algín momento a posibles contactos previos a la Guerra Civil ("tengo el vago recuerdo [le dice carta de 1957] de que el 34 o el 35 nos conocimos en San Sebastín"), su primera carta conorvada

de 1955. ${ }^{16}$ Victoriano Crémer (1907- ). Poeta, novelista y ensayista nacido en Burgos. Tras la Guerra Civil fue encarcelado por sus ideas anarquistas. Una vez liberado se dedicó al periodismo y a la creación

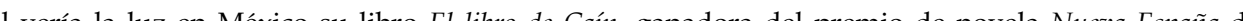
México en 1958.

${ }^{17}$ Juan de Leceta, otro de los sobrenombres poéticos utilizados por Rafael Múgica (Gabriel Celaya) con el que publicó tres de sus más influyentes libros de posguerra: Avisos de Juan de Leceta, Tranquilamente hablando y Las cosas como son, con los que inicia su evolución hacia el llamado social-realismo. Max Aub se refiere aquí al artículo "Poesía arraigada y poesia desarraigada" de Alonso, incluido en Poetas españos contemporaneos, Madrid, Gredos, 1952, p. debido a una errata en la prinera edicion del hibro de Alonso, de donde toma el dato. En cualquier caso, el hecho mismo de que Max Aub no identifique a Celaya tras el alias es significativo de desconexión entre exiliados y residentes a casi veinte años del fin de la Guerra Civil.

18 Ángela Figuera Aymerich (1902-1984). Poeta nacida en Bilbao, trabajó como archivera en la Biblioteca Nacional. Fue una de las primeras y principales mujeres escritoras del panorama literario de la dictadura. Figuera entabla relacion con Max Aub en 1955. Fue el quien gestiona la publicación en México de su obra Belleza cruel, la mejor de todas las suyas, introducida por un impactante y polémico prólogo de León Felipe.

${ }^{19}$ Ciertos cuentos y Cuentos ciertos, México, Robredo, 1955.

\section{UN POETA Y DOS REVISTAS: JOSÉ MARÍA FERNÁNDEZ NIETO EN NUBIS Y} ROCAMADOR

MARIO PAZ GONZÁLEZ

IES “Los Valles”. Camarzana de Tera (Zamora)

\section{LAS REVISTAS POÉTICAS EN LA POSGUERRA}

La presencia de revistas de contenido cultural o poético en una determinada comunidad es reveladora de la intensa curiosidad que embarga a los que la constituyen. Cuando esa curiosidad se produce en épocas de penuria económica, cultural o de libertades, como fue nuestra posguerra, entonces su valor se acrecienta. De alguna manera las revistas poéticas fueron el espejo inmediato y convulso de la realidad en la que se desarrollaron. Fueron también la voz de toda una generación y,

"Recibido: 23-01-2009 Aceptado: 25-03-2009 


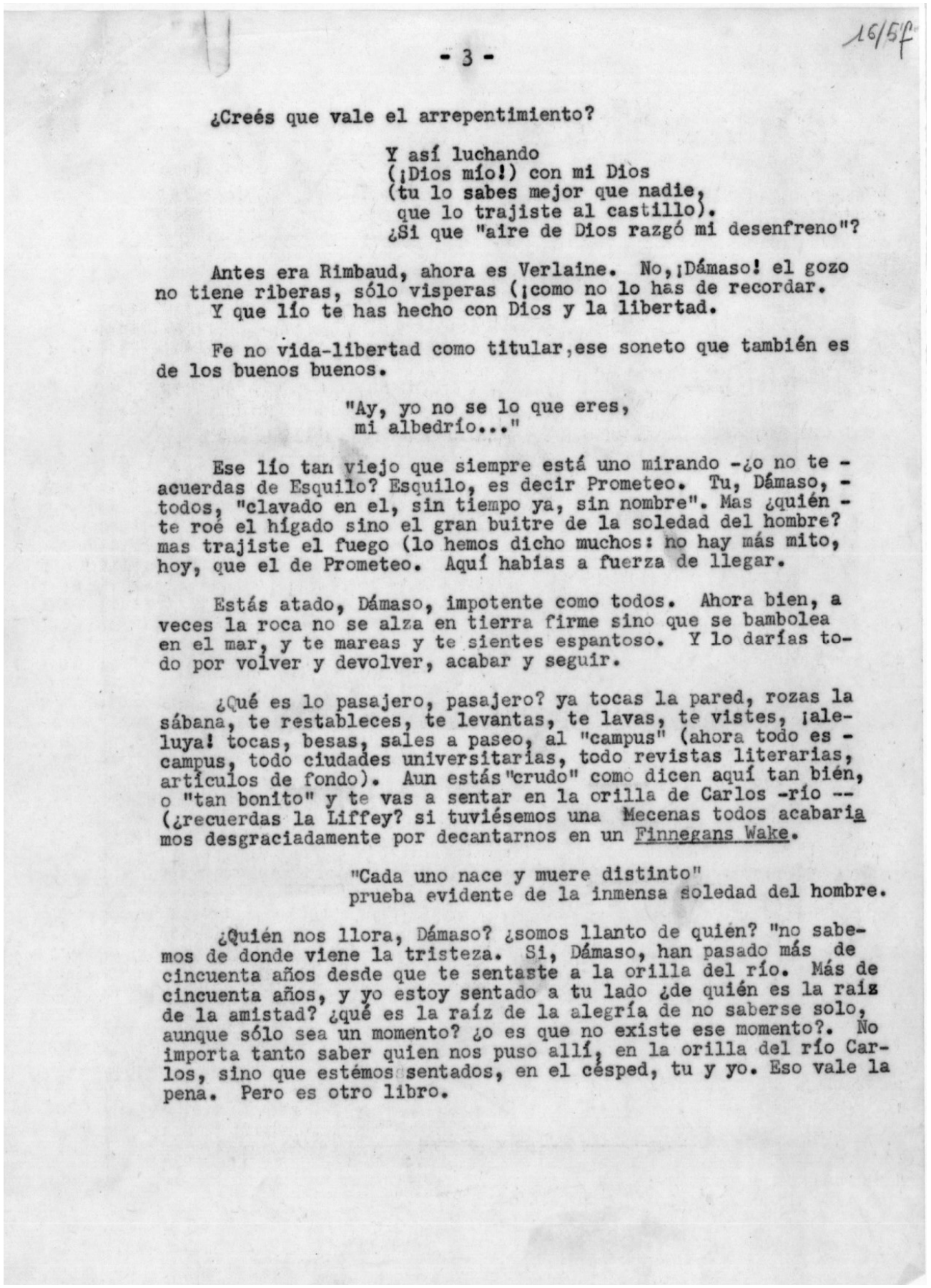

hermosa pierna, como dicen tus amigos los franceses). ¿Dónde mandarles a Melchor ${ }^{20}$ a Gerardo ${ }^{21}$ a José María Cossío $22 ?$

Saluda muy afectuosamente a Elvira y recibe para ti mi más fraternal abrazo.

\section{Tu tierna miopía}

Nosotros, los cegatos; nosotros los miopes. Sí, pero ¿y los lentes? Claro, son industria, pero ¿no lo es la poesía?, ¿no es la poesía anteojos? -anteojos para otros que mutilan el horizonte-. Habrá que cantar las gafas - los Quevedos- ¿o no? ¿quién ve claro? Nadie. ¿Y qué? Allí, los profetas, los blasfemos, los que se atreven: tú.

¿Contra quién luchas?, ¿contra quién te afanas?, ¿a quién majas, galán? Te arremolinas tremolinando, a veces niño con tremenda rabieta a topetear con el aire más duro. Te salen moraduras.

¿A quién hieres, a quién mamporreas, verdugazo de ti mismo? Zurras el bálago que por no decir la enhiesta verdad tan consonante, ¡cómo te quisieras atrincherar en tu miopía!, ¡qué no darías por ello! pero mientes: esa mentira en la que

${ }^{20}$ Melchor Fernández Almagro (1893-1966). Historiador, crítico literario y periodista granadino miembro de la Real Academia de la Historia. Amigo personal de Federico García Lorca y de otros miembros de la Residencia de estudiantes en el Madrid de entreguerras, frecuentaba numerosas tertulias literarias donde hubo de conocer a ambos autores.

${ }^{21}$ Gerardo Diego (1896-1987). Poeta ovetense, uno de los tres miembros "canónicos" de la conocida como Generación poética del 27 que permaneció en España tras la Guerra Civil. Su apoyo explícito al levantamiento militar y su afinidad a la ideología fascista le valió la enemistad de muchos de sus compañeros (la de Juan Rejano, por ejemplo, que le procuró el sobrenombre de "vergonzante juglar de la Falange" que haría fortuna). En 1955, cuando se escribe esta carta, Max Aub y Gerardo Diego no han reanudado todavía sus relaciones epistolares, hecho que sólo tendrá lugar con ocasión del libro de ensayos La poesía española contemporánea. La interpretación que Max Aub ofrece ahí sobre su obra ("Diego representó mucho más de lo que hoy significa en la España oficial"), ofendió al asturiano tan gravemente que, tras una breve misiva, decidió romper definitivamente sus vínculos con Aub.

22 José María de Cossío (1892-1977), escritor y polígrafo nacido en Valladolid, miembro de la Real Academia de la Lengua y presidente del Ateneo de Madrid desde 1962. Fue amigo estrecho de Max Aub en el periodo de la anteguerra, como prueba el prólogo que le dirige dedicándole su colección de poemas $A$, editada en 1933 
estamos envueltos en las más de las borracheras, en los brazos más suaves, en la rabia más placentera.

\section{Mi tierna miopía}

Ay, Dámaso, y la mía: diez dioptrías y me quedo corto.

No acercarse, quedarse con la imperfección, en la imperfección y regodearse en ella. Pero "la realidad (que puede ser hosca)" también - ¡lo sabes!- puede ser otra cosa. La cuestión es perder el miedo, perder el miedo a la cuestión, a la cuestión de la inquisición. He aquí que pides los límites de las cosas, los bordes, los ángulos suponiéndoles hirientes, duros. Palinodia: ${ }^{23}$ tu poema, falso en verdad, porque lo que quieres es seguir en tu dulce penumbra, acogerte a quien o que te la pueda proporcionar - en el límite- como dice el tango "a media luz los dos". ${ }^{24}$ Pero ¿y "la sangre derramada"?, ¿qué hacer, Dámaso, con ella?, porque tú lo gritas: es sangre y no otra cosa. "Inmensos Amazonas vierten sangre en los mares" 25 (dile adiós a Rimbaud, que cruza el fondo en su frágil esquife, arrastrado por una corriente fría en el horizonte. No te preocupes: caerá en la sima, da la vuelta, regresa).

¿Quién creó la injusticia? Tú lo sabes, y lo quieres callar, y ese es el silencio que te agobia $-\mathrm{y}$ no te ahoga, aunque tal vez quieras morir de ese dolor parteroparlero. ${ }^{26}$ Sí: quieres "vivir dentro del orden general / de tu mundo", 27 del mundo del “Gran Dios” (¿cuáles son los demás?).

${ }^{23}$ Poema "1a Palinodia: la inteligencia" (p. 114). Título del texto que se comenta en este párrafo ("Yo quiero / los límites estrictos de las cosas").

24 "A media luz". Tango compuesto en 1924 por los argentinos Edgardo Donato y Carlos Lenzi.

5 Poema "2 2 Palinodia: la sangre" (p. 116)

"Dame, oh gran Dios, los ojos de tu justicia. / Porque en el mundo reina la injusticia. / Tú no creaste la injusticia. Alguien ha creado la injusticia. / Alguien es el injusto, y yo necesito verle la cara a injusto" (p. 117). La referencia es especialmente significativa desde la lectura histórica y en boca de un exiliado republicano. La palabra "parlero" esconde, en ese mismo sentido, alusiones irónicas relevantes desde su sentido principal: "persona que habla mucho, que lleva chismes o cuentos de una parte a otra, o dice lo que debiera callar" (RAE).

${ }^{27}$ Poema "3a Palinodia: detrás de lo gris" (p. 118)

\section{$-2-$}

¿Que es eso de "total rijo sistema/ ...." rijo ide que? ¿de rijoso?. No descubras asi la manta de tu pecho. Es peor, no avisoro adonde te va a llevar tu orgullo. Porque pareces ces Gran Dios, ( $y$ mi perro y mi pluma, y este papel en el cue te escribo) nada valdria la pena de ser, siendo. Y si no lee asi:

Creación tiene un polo, Dámaso se llama oh tiranía, o fuerza de Dámaso aun a Dios mismo en mi cerebro bulle...

B1 sol: el Gran Dios es el sol el que descubres por una de tu cajita le incendia Dios = sol.

"Donde "Dios" (las corilllas no son mias) refulgir solo habrá un gran vacío".

¿Y las cenizas, Dámaso? ¿ya no recuerdas su gusto? olvídate de la Magdalena de Proust o de los riñones de Mr. Bloom. 81: vuelvete 1diota: borrad mi inteligencia que "para su plenitud Según tu solo el "gran vacio" es capaz de alojar al "Cran bobo. iGrand Dieu! como dicen los gabachos.

Así, en tus cabales, qque opinas de un inmenso lago sin --
la? ¿qué somos los demás, peces, infusđrios?. Es decir mudos (1) modestia. I si orilla es demasiado, bástate el junco (juncal) y el delgado recuerdo de Pascal -Pascual-: "Yo, tu Hombre, C'est lan lava de ahora).

iArrepientete pecador! brisa tu brizna en el polvo de la orilla. Y, si no, vamos a vernos las caras pero rehuyes, huyes a tu niñez, al canto cándido, a la estampita para no salir de estampia. Y cargas al pobre muchachillo, 10 abrumas : "niño malo", con filos dorados y godesvaidos y rojos, corazón fluminadol. si", y "cintas azules y blancas de congregantes...de nácar incrustados.

Dámaso, catedrático, ¿cuántos bautizmos "con una mano/ reves tido de estola" has administrado? "miles $\mathrm{y}$ miles". "Sobre cada occipucio una esponjita rubia sutilmente exprimiendo" unas gotas
de filologí románica para que puedan estar seguros de no caer en el limbo.

Perdóname, escribo a medida que 100 , ¿o leo a medida que escribo?.

Tanto yo, en t1

Aquí, de pronto, la miopía sube de grado y crea -no tantoinventa. Bs colaboracionista (Dios = Peíain, tenia buenos bigoMis ojos inventores crean la luz (ianatema!)
colaboran a cada millonésima parte de segund providentenas de la gran creación. 


\section{$16 / 5 d$}

Ahora bien: ¿crees de verdad que Dios (el Gran Dios) sólo puede ver por los ojos del hombre?. Tu, aficionado al cine, ¿crees eso? mira: y ve. Ios personajes de la historia, de cualquier his toria cinematográfica, son V1stos -a veces- los unos por los otros pero muchas o tras - 1 mayoria- son punto de vista de Dios, que es exacta) que ha señalado el Director en el "set".

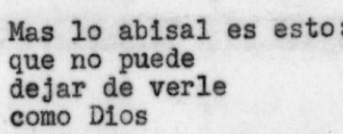

¿Y tu? tu, briago, equiparando al Gran Dios con una docena de high balls por muy high balls que sean) como claro está que a ese paso pasa:

\section{a) Soy dueño de mi albedrío}

b) Me forja (y forjo), obrando
(Marx, Lenin, dialectica marxista)

c) Yo me esculpo, hombre libre.
(Heiddeger, Sartre, fenomenologia, existencialismo.

Todo eso en tres versos. IY viva la Pepa y, sobre todo, como(sindicato único dependiente directamente del F.A.I., en espera de su comision y todos boca abajo "entre atonitos orces incinitos, ante la maravilla libre. Don Damaso Alonso, viajante de Dios, co-

$Y$ que, dejadme solo! -de repente el punto exacto, capitán de tu barco- long1tud $y$ latitud precisas el soneto centro ( $y$ exoneras se en los demás: aquí estoy yo, como quiero, como me da la gana, porque ya

"Mi Dios limita con mi voluntad".

es decir, ya no es sino vecino
y, si quiero alo la pared medianera
y no 10 recibo; desagradecido además

porque él me hizo libre".

Aqui, en el quinto comentario hemos adelantado mucho: "libertad es creacion" (ya no invencion) y siarlas amargas. No lo niego: hay hijos agradecidos. Ya hemos visto que tu no, y dudo mucho que Dios mire complacido como grabas criatura novisima haciendola surgir de la nada. Te estableces por tu cuenta; entablas competencia, ¿acabaras en tablas? (todos acaban the che pero estoy casi seguro de que él debe creerse mejor poeta que tu, que no le puede gustar aunque asegures, petulante, que "nunca su -mano imité".
No estás muy seguro de que tras la imagen del hombre, Dios, refulja el amor. No, no estás muy seguro. ${ }^{28}$ ¿Qué dieras, Dámaso, por un poco de fe? La vida no porque entonces no valdría la pena; sí, la muerte los hombres se la han ofrecido al Gran Dios en todos los idiomas, pintada con todos los colores, pero ¿de qué les sirve?, tiene carretadas de muertos en su huerto, ya no sabe que hacer con ellos. ¡Hay que ver cómo lo abonan!

\section{Hombre y Dios}

Cúrate en salud: "hombre es amor" y duerme tranquilo. No, repites, "hombre es amor y Dios habita dentro / de ese pecho...". ${ }^{29}$

Ahora bien: ¿crees de verdad que Dios (el Gran Dios) sólo puede ver por los ojos del hombre? Tú, aficionado al cine, ¿crees eso? Mira: y ve. Los personajes de la historia, de cualquier historia cinematográfica, ${ }^{30}$ son vistos -a veces- los unos por los otros; pero muchas otras -la mayoría- son mirados por los espectadores desde el ángulo de Dios, desde el punto de vista de Dios, que es el emplazamiento (iqué bonito!, y es la palabra exacta ${ }^{31}$ ) que ha señalado el director en el "set". ${ }^{32}$

Mas lo abisal es esto:
que no puede
dejar de verle
como Dios.

${ }_{28}$ Poema "3a Palinodia: detrás de lo gris" (p. 119). "Dime, Dios mío, que tu amor refulge / detrás de la ceniza. / Dame ojos que penetren tras lo gris / la verdad de las almas".

29 Poema "Hombre y Dios" (p. 123).

30 Poema "La bondad de Dios" (p. 113): “Oh fuerte Dios, / cómo suavizas tu film-creación (itan duro!) para mí". Téngase en cuenta, para completar la referencia, que Max Aub era especialista en cinematografía, llegando a impartir clases en la Universidad Nacional Autónoma de México sobre la materia. Su primera experiencia en el ramo la realizó junto a André Malraux en el rodaje de L'Espoir. Sierra de Teruel durante la Guerra Civil, donde colaboró en calidad de traductor, guionista productor. En su exilio en México, firmó cerca de treinta películas como guionista, adaptador textual arreglista junto a directores como Luis Buñuel (Los olvidados), Jaime Salvador (Marina), Celestino Gorostiza (Sinfonía de una vida, Ave de paso), Adolfo Fernández Bustamante (Barrio de pasiones, sobre un cuento de Dostoievski) o Julio Bracho (Historia de un corazón).

31 Emplazamiento: (Cine) Situación de la cámara. Punto de vista o ángulo que adopta el objetivo a la

32 Set: (Cine; anglicismo). Lugar donde se realiza el rodaje. Incluye los decorados y todos los demás elementos escenográficos necesarios para culminar adecuadamente la toma en dicha ubicación. 
¿Y tú? Tú, briego [sic], equiparando al Gran Dios con una docena de high balls $^{33}$ (por muy high balls que sean) como claro está que ese paso te lleva de la mano, o sostenido por los sobacos - hombres son muletas, hoy por ti...- a cantar la libertad. A ver qué pasa:

$$
\begin{aligned}
& \text { a) Soy dueño de mi albedrío } \\
& \text { (Santo Tomás, idealismo) } \\
& \text { b) Me forja (y forjo) obrando } \\
& \text { (Marx, Lenin, dialéctica marxista) } \\
& \text { c) Yo me esculpo, hombre libre. } \\
& \text { (Heidegger, Sartre, fenomenología, existencialismo) }{ }^{34}
\end{aligned}
$$

Todo eso en tres versos. ¡Y viva la Pepa! y, sobre todo, como dices, la libertad. Dulce terceto de la gente, único del Gran Dios (sindicato único dependiente directamente de la F.A.I., en espera de su comisión, y todos boca abajo "entre atónitos orbes infinitos", ante la maravilla libre. Don Dámaso Alonso, viajante de Dios, comisionista del Padre eterno, ${ }^{35}$ vendiendo libertad a cualquier precio.

Y qué, ¡dejadme solo! —de repente el punto exacto, capitán de tu barcolongitud y latitud precisas el soneto centro, y exonerarse en los demás: aquí estoy yo, como quiero, como me da la gana, porque ya

$$
\begin{aligned}
& \text { "Mi Dios limita con mi voluntad". } \\
& \text { Es decir, ya no es sino mi vecino } \\
& \text { y si quiero alzo la pared medianera } \\
& \text { y no lo recibo; desagradecido además } \\
& \text { "porque él me hizo libre". } 36
\end{aligned}
$$

Aquí, en el quinto comentario hemos adelantado mucho: "libertad es creación" (ya no invención) y si eres capaz de crear el Gran Dios, apuesto a que a la vuelta vas a pasarlas amargas. No lo niego: hay hijos agradecidos. Ya hemos visto que tú no, y

33 Nombre que denomina en inglés un combinado de bebida alcohólica y refresco; así llamado por ser habitualmente servido en vaso alto de cristal.

${ }^{4}$ Poema "Creación delegada", integrado en la serie "Cuatro sonetos sobre la libertad humana" ( $p$ 138).

35 La referencia puede hacer una alusión cómplice al título de su relato "El limpiabotas del Padre Eterno", incluido en su volumen No son cuentos de 1944, en el que Max Aub regresa sobre sus experiencias en el campo de concentración de Djelfa en la Argelia francesa.

36 Poema "Quinto comentario" (p. 140)

\section{Tu tierna miopla}

Nosotros, los cegatos; nosotros los miopes. S1, pero iy los lentes? claro, son industria pero ino lo es la poesla? ino es la poesía anteojos? nadie. ¿Y que? alli, los profetas, los blasfemos, los que se -.atreven: tu.

Contra quien luchas? ¿contra quien te afanas? ¿a quién majas, bleta a topetear con el a1re más đuro. Te sale moraduras.

¿A quién hieres, a quien mamporreas verdugazo de ti mismo?. Zurras el bálago que por no decír la enhiesta verdad tan consonan te, fcómo te quisiera atrincherar en tu miopíal qque no darías por las más de las borracheras, en los brazos más suaves, en la -rabia más placentera.

\section{Mi tierna miopia}

Ay Dámaso, y la mia: diez dioptrlas y me quedo corto. No acercarse, quedarse con la imperfección, en la imperfec-ción y regodearse en ella. Pero la reallad (que puede ser hosca)" tamblen - 10 sabes!- puede ser otra cosa. la cuestion es per in des, los ángülos suponiéndoles hirientes, duros. Palinodia: tu -poema falso en verdad, porque 10 que quieres es seguir en tu dulce penumbra, acogerte a quien "que ia la pueda po" porctor limite- como dice el tango "a media luz los dos". Pero ¿y"la san es sangre 1 no otra cosa. "Tnmensos Amazonas vierten sangre en -los mares (dile adiós a Rimbaud, que cruza el fondo en su frágil esquife, arrastrado por una corrlente frla en el horizonte. No te preocupes: no caerá en la sima, da la vuelta, regresa).

¿Quién creó la injusticia? tu lo sabes, y lo quieres callar, 作 uisieras morir de ese dolor partero- parlero. s1: quieres "vivir" (cuales son los demás?).

No estás muy seguro de que tras la 1mágen del hombre, Dios,

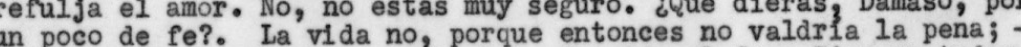
si la muerte los hombres se la han ofrecido al Gran Dios en todos los lalomas, plntada con todos los coloche pero re? tiene carretadas de modto

\section{Hombre y Dios} Curate en salud: "hombre es amor" y duerme tranquilo. No, --
repites, hombre es amor $y$, Dios habita dentro/ de ese pecho...". 


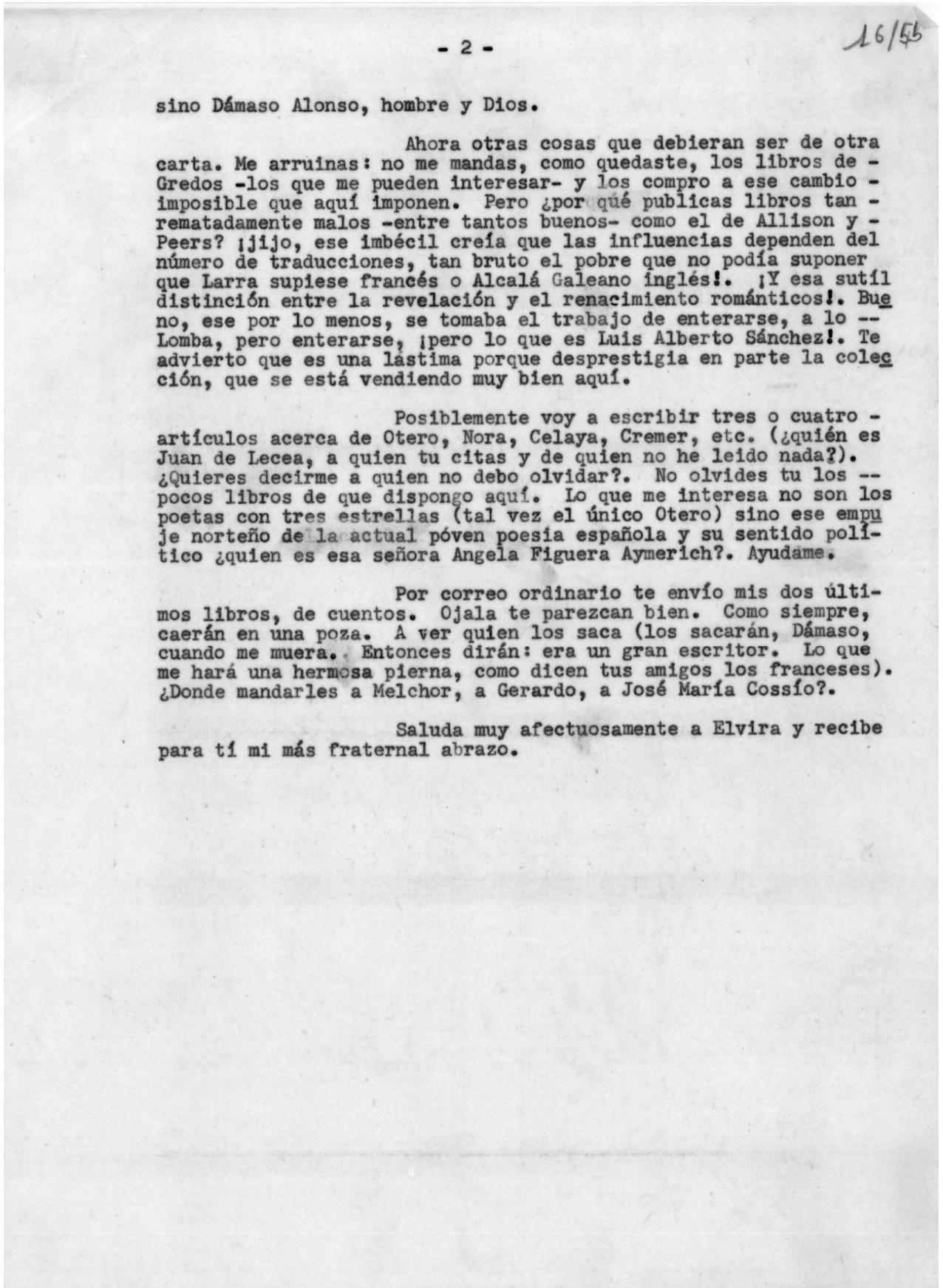

dudo mucho que Dios mire complacido como grabas, criatura novísima, haciéndola surgir de la nada. Te estableces por tu cuenta; entablas competencia, pero estoy casi seguro de que él debe creerse mejor poeta que tú, y es de generación anterior. Te aseguro - ¿no eres también crítico? - que no le puede gustar aunque asegures, petulante, que "nunca su mano imité".

¿Qué es eso de "total rijo sistema / ...", rijo ¿de qué?, ¿de rijoso?37 No me descubras así la manta de tu pecho. Es peor, no avizoro adónde te va a llevar tu orgullo. Porque pareces seguro de estar habitado por el Gran Dios, pero ¿y los demás?, ¿así nos desamparas? Porque si cada uno de nosotros alberga un Gran Dios, (y mi perro y mi pluma, y este papel en que te escribo) nada valdría la pena de ser, siendo. Y si no lee así:

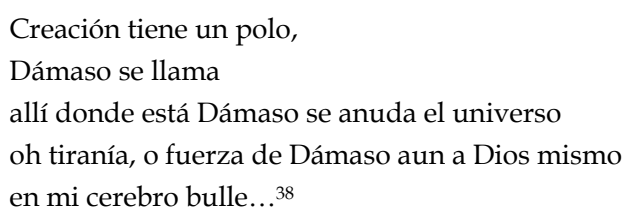

El sol: el Gran Dios es el sol, el que descubres por una sencilla ley física, a pesar de tu miopía. Un lente en la tapa de tu cajita le incendia Dios $=$ sol.

“Donde «Dios» (las comillas no son mías) refulgir solo habrá un gran vacío".

¿Y las cenizas, Dámaso?, ¿ya no recuerdas su gusto? Olvídate de la Magdalena, de Proust o de los riñones de Mr. Bloom. ${ }^{39}$ Sí, vuélvete idiota: borrad mi

37 Poema "Hombre y Dios" (p. 123). Los versos seleccionados por Aub se corresponden con los del primer terceto: "Amor-Hombre, total rijo sistema / yo (mi Universo)". El comentario de Max Aub destaca irónicamente la palabra "rijo" desligándola de su referencia gramatical (primera persona indicativa del verbo regir).

Max Aub sobrescribe aquí el poema "Segundo comentario" (p. 124) sustituyendo el sustantivo "hombre" del original, por el nombre propio "Dámaso". Paradójicamente, Aub refuerza así la humanización de su comentario, restando la categoría más universal y personalizándola en la figura del poeta. Se ha optado por hacer visible la variante manteniendo la letra cursiva para las citas literales y la redonda para la glosa.

39 Personaje principal de la novela Ulises de James Joyce, autor favorito de Dámaso Alonso de quien tradujo su Retrato del artista adolescente en 1926. La referencia a los riñones puede aludir al recorrido nocturno que Leopold Bloom y su amigo Stephan Dedalus realizan por los locales y tabernas de los barrios bajos dublineses 
inteligencia que "para su plenitud Dios necesita el hombre" - pero deshecho, quemado, polvo o bobo. Según tú, sólo el gran vacío es capaz de alojar al "Gran Dios", ¡Grand Dieu!, ${ }^{40}$ como dicen los gabachos.

Así, en tus cabales, ¿qué opinas de un inmenso lago sin orilla?, ¿qué somos los demás, peces, infusorios? Es decir, mudos y sin espacio; tu sola voz; sólo tú puedes cantar, oh espejo de modestia. ${ }^{41} \mathrm{Y}$ si la orilla es demasiado, bástate el junco (juncal) ${ }^{42}$ y el delgado recuerdo de Pascal -Pascual-: "Yo, tu Hombre", C'est Mon Homme (del tango de antes a la java de ahora).$^{4}$

¡Arrepiéntete pecador! Brisa tu brizna en el polvo de la orilla. Y, si no, vamos a vernos las caras; pero rehuyes, huyes a tu niñez, al cálido cándido, a la estampita para no salir de estampía. Y cargas al pobre muchachillo, lo abrumas: "niño malo", perezoso, aburrido. ¡Ay las blancas "racheadas ráfagas de piedad" con filos dorados y godesvaídos y rojos, corazón iluminado! Sí, y “cintas azules y blancas de congregantes.. de nácar incrustados". 44

Dámaso, catedrático, ¿cuántos bautismos "con una mano / revestido de estola" has administrado? "miles y miles". 45 Sobre cada occipucio una esponjita rubia sutilmente exprimiendo unas gotas de filología románica para que puedan estar seguros de no caer en el limbo.

${ }^{40}$ Max Aub utiliza de forma irónica la traducción literal de la expresión "Gran Dios" al francés, donde se emplea como exclamación en el lenguaje común.

41 "Dios es inmenso lago sin orilla [...] Yo, límite de Dios [...] Yo ribera de Dios, junto a sus olas grandes" (p. 128).

${ }^{2}$ Poema "Tercer comentario (Recuerdos del colegio)" (p. 139) "Yo soy tu junco. Yo quise ser tu báculo. Cuántas veces de niño vi las representaciones / groseras / de tu forma sin forma".

3 "Mon Homme". Célebre canción de cabaret popularizada en 1920 por la vedette, cantante y actriz del Music Hall parisino Mistinguett (Jeanne Bourgeois)

Poema "Tercer comentario" (p. 132). La utilización de los puntos suspensivos es significativa. Sustituyen éstos a párrafos alusivos a la conquista de América; en la lectura histórica propuesta, parece especialmente relevante de cara a la interpretación de un exiliado como Max Aub: "Todos lo heresiarcas se ponían en pie, juntas las manos, / y con cintas azules y blancas congregantes iban / recibir humildes el bautismo, y la sagrada comunión. / Detrás una borrosa caterva / (todos, indios, / más algún negro) silenciosa avanzaba / con plumas de colores, como en un cuadro, aquellos / (La conquista / de México, con equis) de nácar incrustados".

${ }^{45}$ Poema "Tercer comentario" (p. 132).

Méx10o, D. F., agosto 30 de 195

Sr. don Dámaso Alonso
Coionia del Zarzal San Martín de la Rosa,
Madrid, España.

Mi querído Dámaso:

tu poema, después de hab correr de los ojos, mientras que leía tomando unas notas, como sí hubléssels estado sentado enfrente
de mi. Te las mando, sin max ni más.

Recib1 tu libro, tan precioso por dentro cón una portada que la, 10 abrí con el cuchillo de postre y nos lo tomamos con el Tal vez no es un libro tan importante como
tus H1jos, porque aquellios abarcan más, pero es un poema, sólo de una pleza más resignado, to blosfemo $11 b r o$ más unido, más tu obra, muy importante, porque sólo el contemplador faltaba. Ya no te falta, te miras a tí mismo. Tu, el cáos, a veces mundo do ya to ves. que te hiciste pero, iy si te hubiesen creado a tu pespo sines saber1o? "solo el contemplador faltaba", el testigo, el test' tugailina-huevo, todo es cuestión de lo último, plure hay problema

que te abriste, nació ae da la impresión que tu poema, esa vena

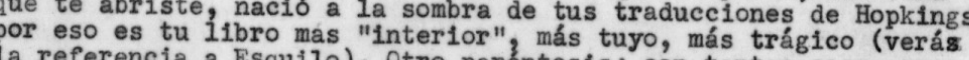
a Esquilo). Otro paréntesis : con tantas cosas com solación de la Carroña" antes de que Hopkings escribio su "Consu vejez viruelera. y luego él la puso en cristiano-jesuita, en

oder charlar cuando menca he sentido más no tenerte a mano para cada día más. He aquí un largo poema enconado como estamos y hombre Dámaso. Te sal16 como po verruga odo -enconiado- en el cialistas pronos ticaron Dios, hiciste muchos análisis - con jubi10, con ansledad- todos ay, negativos. 10 que es 10 mismo "Ilamadle como queráis". "Tu libro no debe

Dámaso Alonso

Hombre y Dios 
Perdóname, escribo a medida que leo, ¿o leo a medida que escribo?

Tanto yo, en ti.

Aquí, de pronto, la miopía sube de grado y crea -no tanto-: inventa. Es colaboracionista (Dios=Petain, tenía buenos bigotes, faltóle la barba46). No invento:

Mis ojos inventores crean la luz (janatema!)

colaboran a cada millonésima parte de segundo

en el plan (¿quinquenal?)

providentes de la gran creación. ${ }^{4 / 2}$

¿Crees que vale el arrepentimiento?

$$
\begin{aligned}
& \text { Y asíl luchado } \\
& \text { (Dios mío!) con mi Dios } \\
& \text { (tú lo sabes mejor que nadie, } \\
& \text { que lo trajiste al castillo). } \\
& \text { ¿Si que "aire de Dios rasgo mi desenfreno"? }
\end{aligned}
$$

Antes era Rimbaud, ahora es Verlaine. No, ¡Dámaso!, el gozo no tiene riberas, sólo vísperas (¡cómo no lo has de recordar!) Y qué lío te has hecho con Dios y la libertad. Fe no, vida-libertad como titular, ese soneto que también es de los buenos, buenos.

$$
\begin{aligned}
& \text { “Ay, yo no sé lo que eres, } \\
& \text { mi albedrío..."48 }
\end{aligned}
$$

Ese lío tan viejo que siempre está uno mirando - ¿o no te acuerdas de Esquilo? Esquilo, es decir, Prometeo. Tú, Dámaso, todos, “clavando en él, sin tiempo ya, sin nombre" ${ }^{49}$ Mas, ¿quién te roe el hígado sino el gran buitre de la soledad del hombre?; mas trajiste el fuego (lo hemos dicho muchos: no hay más mito hoy que el de Prometeo). Aquí habías, a fuerza, de llegar.

${ }^{6}$ Philippe Petain (1856 - 1951). Militar y político francés, jefe del estado entre 1940 y 1945. Su política de colaboración con el nazismo desde el gobierno de Vichy que dirigía, le valdría la condena a pena de muerte por traición a la patria en 1945, conmutada después por degradación y cadena perpetua. Poema "Cuarto comentario" (p. 134)

${ }^{48}$ Poema “Vida-Libertad" (p. 143). Se trata de un verso endecasílabo. Cortado así en el original. ${ }^{49}$ Poema "Soledad en Dios" (p. 144). 
Estás atado, Dámaso, impotente como todos. Ahora bien, a veces la roca no se alza en tierra firme sino que se bambolea en el mar, y te mareas y te sientes espantoso. Y lo darías todo por volver y devolver, acabar y seguir.

¿Qué es lo pasajero, pasajero? Ya tocas la pared, rozas la sábana, te restableces, te levantas, te lavas, te vistes, jaleluya!, tocas, besas, sales de paseo, al "campus" (ahora todo es campus, todo ciudades universitarias, todo revistas literarias, artículos de fondo). Aun estás "crudo" como dicen aquí tan bien, o "tan bonito" y te vas a sentar en la orilla de Carlos -río-50 (¿recuerdas la Liffey?) ${ }^{51}$ Si tuviésemos una Mecenas todos acabaríamos desgraciadamente por decantarnos por un Finnegans Wake. ${ }^{52}$

\section{"Cada uno nace y muere distinto" \\ prueba evidente de la inmensa soledad del hombre.}

¿Quién nos llora Dámaso? ¿Somos llanto, de quién? No sabemos de donde viene la tristeza. Sí, Dámaso, han pasado más de cincuenta años desde que te sentaste a la orilla del río. Más de cincuenta años, y yo estoy sentado a tu lado ¿de quién es la raíz de la amistad?, ¿qué es la raíz de la alegría de no saberse solo, aunque sólo sea un momento?, ¿o es que no existe ese momento? No importa tanto saber quien nos puso allí, en la orilla del río Carlos, sino que estemos sentados, en el césped, tú y yo. Eso vale la pena. Pero es otro libro.

${ }^{50}$ Se refiere al Charles River de Boston, río que separa la ciudad del distrito de Cambridge, donde se ubica la Universidad de Harvard. Dámaso Alonso impartió allí cursos de Lengua y Literatura españolas en el mismo año 1954. La referencia está ligada al poema que cierra Hombre y Dios, fechado ( Charles River), titulado "A un rio le llamaban Carlos (p. 150). La homonimia con el presente

${ }^{51}$ Por el contexto, Aub parece referirse al río Liffey de Dublín y al paseo que lo bordea conocido popularmente como "La Liffey". Dado que carecemos de noticias que sitúen a Max Aub y a Dámaso Alonso juntos en Irlanda, cabría entender, tal vez, una nueva alusión a algún pasaje o novela de James Joyce. La referencia es hoy, en todo caso, indescifrable.

52 Célebre canción popular irlandesa, habitualmente cantada en funerales, que ironiza sobre la resurrección a través del güisqui. Tiene relación con el sentido etimológico de la palabra "whisky" en gaélico ("el agua de la vida") y ha adquirido un carácter simbólico como representación del ciclo vita del hombre. La balada dio título a la última novela de James Joyce, a la que probablemente alude Aub jugando a la vez con la canción funeral, la alusión alcohólica y la referencia bibliográfica. 
biográfica como la perspectiva de quienes tuvieron un papel preponderante en la formación de su personalidad. ${ }^{3}$

La estructura permite hablar de novela diferida en cuanto no es ya él - que también tendrá su papel preponderante en el último apartado, el narrador - sino que serán los otros, sus familiares, los que facilitarán su visión particular, o mejor dicho, sus visiones particulares:

No me interesaba una visión directa del personaje, sino que me gustaba más relatar lo que pensaban otras personas que estuvieron cerca de él y se me ocurrió que fueran ellos los que contaran sus experiencias, para que se desvelaran sus roces con la vida, desde cinco puntos de vista fundamentales: el padre, la madre, la amante, su mujer y él mismo. ${ }^{4}$

La técnica del poliedro, organizado sobre el monólogo interior de los personajes que nos ayudan a conocer la realidad personal y vital de Thomas de Quincey, organiza el esquema narrativo, pero también la del contrapunto de ideas, perspectivas y situaciones determina el edificio narrativo, aunque bien es verdad que Rafael Ballesteros ha tendido a no repetirse y adentrarse en los acontecimientos más trascendentes, soslayando aquellos que ha considerado inanes:

Cada personaje ilumina a De Quincey y, al mismo tiempo, ilumina zonas de la personalidad de los demás y del propio narrador en cada situación; con lo que la eficacia del texto aumenta y las posibilidades de interpretación se abren para el lector..$^{5}$

Creo que la novela ofrece un gran esfuerzo de contención porque es habitua en este tipo de obras explayarse innecesariamente, toda vez que es fácil, tanto por las autobiografías del propio escritor como por documentos de la época, adentrarse en una verborrea innecesaria:

La base de la narración son los propios textos del autor (Confesiones de un inglés comedor de opio; Los últimos días de Emmanuel Kant...) y los de sus biógrafos. Amplia documentación, pues, en la base de este libro, que no resta un ápice de creatividad y equilibrio al resultado.

3 D. Ródenas de Moya, «La perspectiva como arte», Libros, El Periódico de Catalunya, 15 de febrero (2007), p. II.

R. Cortés, «Ballesteros novela la vida y obra de Thomas de Quincey», Sur, 10 de noviembre (2006).

5 A. Garrido Moraga, «Thomas de Quincey y los puntos de vista», Sur, 26 de enero (2007), p. 76

${ }^{6}$ R. Romojaro, «Cuando el autor cede su voz», ABC de las Letras, 779 (2007), p. 15
Literarios» celebrados en el colegio marista donde Dacio ejercía como docente. En el sábado dedicado a los «Poetas palentinos de ayer y hoy» (celebrado el 23 de febrero de 1946) Carriedo leerá su «Romance a José M. ${ }^{a}$ peregrino por Granada», pues a esta ciudad Fernández Nieto se había desplazado para estudiar la carrera de Farmacia. Probablemente por obra de nuestro poeta se contactó también con una publicación granadina que será comentada en el número 2 de Nubis (octubre, 1946) en la sección «evista de revistas».10

La presencia de Fernández Nieto en «Nubis» sería decisiva. En su mandato al frente de la Peña será conocido, según consta en acta de la asociación fechada el 7 de junio de 1947, como «El Indulgente, la República».11 Además su denodado interés por la poesía, así como su innata facultad para el género habían quedado ya sobradamente de manifiesto con la concesión de diversos premios en esos años: el de la Asociación de la Prensa en 1942, por su composición «Elegía y muerte del río Carrión»,12 Flor Natural en el Certamen Nacional de 1943, también en los Juegos Florales del centenario de Zorrilla en 1944, en la Fiesta de Exaltación Palentina de $1945^{13}$ o en el certamen provincial organizado por «Nubis» en un «Homenaje a Rubén Darío» celebrado el sábado 12 de enero de 1946. Además, contaba en su haber con un librillo, Ramillete de poesías (1944), que recogía su primera (y tal vez más ingenua) producción. ${ }^{14} \mathrm{Su}$ libro Sin primavera, editado en este momento, contiene diecinueve poemas de variada hechura formal que ya reflejan una de las constantes de su obra, un afán de clasicismo (plasmado en sonetos y romances

${ }^{10}$ Dicha publicación se llamaba Avellano y llevaba por subtítulo, en cierta coincidencia con la palentina, «Pasquín de las ideas y de las letras», dirigida por F. del Darro y con Pedro de Granada como redactor-jefe. Tenía el mismo carácter heterodoxo, no solo poético, de Nubis, pues incluía, junto a las colaboraciones literarias, «pasatiempos, crucigramas, sección de modas...». Vid. Fanny Rubio, op. cit., p. 396.

${ }^{11}$ Vid. César Augusto Ayuso, op. cit., p. 643.

${ }^{12} \mathrm{Vid}$. César Augusto Ayuso, op. cit., p. 637.

${ }^{3}$ Como se dice en Nubis, 1 (septiembre, 1946), pp. 12-13.

${ }^{14}$ Editado en Almería, según Fernando Presa González: «En él hay huellas de muchos nombres importantes de nuestra Literatura, en especial de los poetas del 27 y de los vanguardistas hispanoamericanos, aunque también de los clásicos del Siglo de Oro se dejan entrever». Cfr. Fernando Presa González, «José María Fernández Nieto. Medio siglo de poesía», PITTM, 62 (Palencia, 1991), p. 30.

LECTURA Y SIGNO, 4 (2009), pp. 189-212 
fundamentalmente) y una cierta mirada hacia la modernidad (marcada por la polimetría y el versolibrismo). La influencia del 27 y de Machado (tal como ocurría en sus primeros versos) es patente, aunque el peso de la nostalgia presente en las composiciones se mitiga con un anhelo de esperanza y deseo de redención para los hombres, es decir, un ansia de infinitud que estará muy presente en muchas de sus composiciones posteriores.

Su participación en los múltiples eventos anteriormente citados será total y plena, por lo que no es extraño encontrarlo también en la lectura pública realizada, junto a Carriedo, el 14 de junio de 1946 en el homenaje celebrado en el Teatro Principal al Nobel español (1922) Jacinto Benavente. Pero, sobre todo, en el «Juicio Literario al Modernismo» celebrado el 8 de junio de ese mismo año y en el que, de nuevo junto a Carriedo y acompañados por Buisán, tomará partido a favor de este movimiento frente a sus detractores, encabezados por Mariano del Mazo. También tomará parte activa en recitales radiofónicos como el «Retablo romántico de noviembre», el día octavo de ese mes, otra vez en compañía de Carriedo y Buisán, con la presencia ahora, además, de Jesús Unciti Urniza.

\subsection{Presencia poética en Nubi}

En lo que a la revista se refiere, su presencia es abundante en la primera etapa (1946-1951), etapa en la que mantiene el subtítulo de «Silva de las ideas y de las letras». ${ }^{15}$ Comentamos sólo algunos ejemplos significativos. En su primer número (septiembre 1946), protagoniza la sección «Nueva lírica» de las páginas centrales. Allí es calificado como poeta de «fibra y raigambre netamente castellana». El soneto publicado, «Ser sin ti», es una composición de juego conceptista y ecos netamente

${ }^{15}$ En homenaje «a aquella Silva Palentina, renacentista, obra del filo erasmista Alonso Fernández de Madrid, Arcediano del Alcor y Canónigo de la Catedral de Palencia». Cfr. César Augusto Ayuso, La poesía de Gabino-Alejandro Carriedo, Oviedo, Universidad de Oviedo, 1990, p. 71. además de un número singular e importante de colaboraciones en revistas y periódicos. Entre sus obras podemos nombrar A las puertas de Macbeth, Suspira de Profundis (1845), (continuación de las Confesiones), Juana de Arco (1847), El coche correo inglés (1849) y Apuntes autobiográficos (1853).

Ante esta biografía resumida, ¿cómo plantea su novela Ballesteros? Una de las grandes advertencias para cualquier narrador es cómo debe organizar su novela, qué punto de vista introducir, qué narrador debe desarrollar la trama, qué estructura $u$ orden/desorden debe llevar, cómo ha de ser su lenguaje, su estilo... En definitiva, la arquitectura narrativa. Por cuanto, la construcción de una novela es como la de un edificio, con sus habitaciones, salones, cuartos de baño, sumideros y puntos de luz y sombras.

Ballesteros ha confesado que inicialmente quiso que su protagonista se hiciera pasar por un alumno de Kant, al que visita con frecuencia y con el que habla de política y filosofía. Y a través de esos encuentros iría relatando la degradación y muerte de Kant, de forma imaginaria; sin embargo, no lograba «encontrar el tono» a su novela desde esa perspectiva, por lo que optó por una estructura narrativa diferente:

Para Rafael Ballesteros, como en su día para Borges o Baudelaire, De Quincey evoca en cambio todo un convulso mundo, cuyos altibajos conocemos bien gracias al carácter autobiográfico de sus Confesiones de un inglés comedor de opio. En ellas se halla, sin duda, el origen de esta caleidoscópica novela, cuyo título y planteamiento son, a su vez, un guiño al ensayo inglés Los últimos días de Emmanuel Kant. ${ }^{2}$

A través de la visión de sus seres más queridos, el lector va adentrándose en la personalidad del hombre y del escritor Thomas de Quincey:

Ballesteros ofrece un recorrido cronológico no tanto por la azacaneada vida de De Quincey como por la forja de su carácter. Lo que le interesa no es tanto la trama

${ }^{2}$ R. Ruiz Garzón, «Los últimos días de Thomas de Quincey», Qué leer, febrero (2007), p. 95.

LECTURA Y SIGNO, 4 (2009), pp. 213-222 
Lo que se propone Rafael Ballesteros en Los últimos días de Thomas de Quincey (DVD Ediciones, Barcelona, 2006) es novelar una vida, la del escritor inglés nacido en Manchester el 15 de agosto de 1785 y muy apreciado en su momento por Charles Baudelaire, Edgar Allan Poe, y, en general, por los decadentistas del XIX, sobre todo en su descripción de los mecanismos de la mente en las pesadillas:

La novela bebe de aquellos momentos históricos tan relevantes con los que, al nacer en 1785, coincidió su paso por la vida. Vivió de cerca las consecuencias de la Revolución Francesa, vive de lleno todo el hervidero del Romanticismo y participa del utilitarismo inglés que desembocó en la revolución industrial. ${ }^{1}$

Opiómano, consumidor habitual de la adormidera (de uso legal en Europa hasta 1813), Thomas de Quincey escribió tratados teóricos sobre narrativa, filosofía y economía, siendo muchos de sus textos publicados por entregas en las revistas de la época. En este sentido podemos citar su obra El asesinato considerado como una de las bellas artes (1927), resultado de su trabajo como director de la Westmorland Gazette.

Como estudiante de griego en la Universidad de Oxford, De Quincey tiene su primer contacto con la droga en 1804, pero también conoce por entonces a los poetas Coleridge (opiómano como él), y Wordsworth, su gran maestro. Se casa en 1816 con Margaret Simpson. A partir de entonces, Thomas de Quincey se verá obligado a escribir para mantener a su familia, y se sentirá agobiado a este respecto hasta que murió en Edimburgo en 1859, oprimido por la pobreza.

Las páginas más enternecedoras de su vida se refieren al encuentro con una joven enferma y aprensiva. Sin embargo su amor platónico será Ann, una muchacha de la calle, que se convertiría con el tiempo en una de las visiones más frecuentes en sus delirios de opiómano.

La producción ensayística de Quincey es de gran valor y destacamos, aparte de la citada, los estudios sobre filósofos alemanes como Kant, Lessing, Richter...,

C. G. Montilla, «Rafael Ballesteros dedica una novela a Thomas de Quincey», El Mundo, 20 de noviembre (2006), p. 10. áureos, quevedescos, en la que el poeta manifiesta su vacuidad ante la ausencia de la amada:

$$
\begin{aligned}
& \text { Sin ti ya no soy lo que pretendo, } \\
& \text { mezcla de tu existencia y de la mía, } \\
& \text { y ¿cómo voy a ser lo que sería } \\
& \text { si ni siquiera soy lo que voy siendo? }
\end{aligned}
$$

$\mathrm{Al}$ mismo tiempo, en un apartado de noticias breves, «Al son del cimbalillo» (p. 24), se dice que el ya citado Sin Primavera, publicado en enero de ese año, «ha sido acogido calurosamente por la crítica de toda España, destacando por su elogio las recensiones de José Sanz y Díaz ${ }^{16}$ y las revistas Espadaña y Valor y Fe». ${ }^{17}$

En el segundo número, también en la sección «Nueva lírica» (pp. 12-13), dedicada ahora a Carriedo, se incluye el poema «A un clavo en la pared», soneto que por su temática se emparentaría con la producción de muchos de sus contemporáneos, no sólo palentinos. El texto va acompañado de unas breves notas bio-bibliográficas, así como de otras composiciones de poetas de la ciudad del Carrión: «Estío», de Gabino-Alejandro Carriedo; «Retorno», de Jesús Unciti Urniza; «Estanque azul», de Félix Buisán Citores, y «Tu amistad», de Enriqueta Palacios.

En Nubis, 3 (diciembre, 1946), el poema de Fernández Nieto ya no aparecerá en las páginas centrales, en la sección «Nueva lírica», sino en la página siguiente que, hasta entonces había estado destinada a la adaptación por nuestro autor de autores extranjeros como el irlandés Cecil Day-Lewis, ${ }^{18}$ con «El álbum» (Nubis, 1, p. 14) o la norteamericana Idella Purnell (Nubis, 2, p. 14). El poema del palentino aparecido en este número tercero, y titulado «Los hombres», es una extensa composición que, aunque en la intensidad y el uso de determinadas imágenes recuerda al

${ }^{16}$ Según se recoge en las actas de la Peña, José Sanz y Díaz, de la tertulia madrileña de «Pombo», había escrito una carta dando ánimos al joven poeta.

17 También en Espadaña, 22 (1946), s. p., aunque 2, donde se puede leer: «En la ciudad castellana se ha creado un núcleo poético cuya primera manifestación es este librito de poemas, en el que su auto muestra su bien dotada personalidad poética, a pesar de ciertas indecisiones y de las tenues pinceladas, de poso romántico que restan originalidad a los poemas. No obstante, en José M Fernández Nieto hay un poeta de vena delicada, digno de atención».

${ }^{18}$ Cecil Day-Lewis (1904-1972) poeta y autor de novela negra bajo el seudónimo de Nicholas Blake.

LECTURA Y SIGNO, 4 (2009), pp. 189-212 
Tremendismo cremeriano, culmina mostrando un sentimiento de piedad y de espiritualidad que no será ajeno a buena parte de su producción. Por otro lado, el deseo de comunión con el ser humano parece una clara respuesta a las críticas recibidas por su artículo sobre Gabriel y Galán publicado en la página 7 de Nubis, 2 (octubre de 1946). También el cierre del poema:

$$
\begin{aligned}
& \text { (Solamente unos hombres } \\
& \text { A quienes otros hombres suelen llamar poetas, } \\
& \text { Entienden el milagro de ascender a la altura } \\
& \text { Burlándose del cuerpo como globos cautivos } \\
& \text { Que rompen sus cadenas. } \\
& \text { Pero a veces, tan sólo...) }
\end{aligned}
$$

En aquel artículo, titulado «José María Gabriel y Galán. La negación del artista», Fernández Nieto, siguiendo a Eugenio D'Ors, alababa las virtudes del salmantino como transmisor del sentir popular, pero calificándolo fundamentalmente de sociólogo que «puede llegar también a tocar nuestra emoción», antes que poeta. El artículo será contestado en el número siguiente por Fernando G. Blanco, ${ }^{19}$ quien acusa a Fernández Nieto de defender una concepción del arte como algo elitista pensado para minorías. Pero lo que realmente ofrece interés en el texto de Fernández Nieto es la visión que aquí aporta del arte literario y que podría leerse a modo de primera Poética:

El Poeta, con esa mayúscula que le da el lirismo, es todo lo contrario del pausado razonador, del que pregunta, del que contesta. Es el que tiembla de por sí sólo cuando va encontrando los vientos que mueven sus fibras y las lluvias que humedecen sus ojos. Él no se para a ver por qué esto es así o por qué es de la otra manera. Es un puro temblor del alma al chocar con otras almas. No el indignado espíritu que clama porque está observando que un grupo de hombres padece sufrimientos de hambres o de desesperanzas. Es el clamor de su mismo sufrir universalizado en todos los que sufren.

El tono de la reflexión, esa crítica implícita a una lírica de raíz exclusivamente social, de algún modo anticipa preocupaciones análogas que, años después, plasmará en los editoriales de Rocamador. Para él la poesía no debe ser un instrumento de

\section{LOS ÚLTIMOS DÍAS DE THOMAS DE QUINCEY DE RAFAEL BALLESTEROS}

\author{
FRANCISCO MORALES LOMAS \\ Universidad de Málaga
}

Novelar vidas de escritores posee la magia de la versatilidad, la adaptabilidad al medio, la seducción, pero también confina en su seno una perversión: el crear una sola imagen, el encerrar una perspectiva abierta, la de la vida de un escritor, $y$, en definitiva, el cercenar la amplitud de una existencia. Es un fenómeno complejo y difícil por cuanto cualquier cosa que hagamos siempre puede ser fácilmente reducida a la arbitrariedad crítica. Un riesgo que asume el novelista ab initio y su capacidad para llevar a cabo semejante contingencia debe ser también ensalzada.

"Recibido: 12-03-2009 Aceptado: 04-05-2009 
1982), Nueve sonetos eucarísticos (Palencia, 1992), Fulgores de ascensión (Colección Rocamador, Palencia, 1993)...

En fin, se trata de una amplia y densa trayectoria que, partiendo de la experiencia acumulada a la luz de su presencia en estas dos revistas, se ha visto marcada por una absoluta coherencia y madurez, con la que el poeta ha cultivado por igual con secreta y hábil maestría, como se ha dicho, formas tanto tradicionales como modernas. Su forma de entender el hecho poético desde una óptica muy personal, para algunos discutible, no está reñida con una estética equilibrada y una firmeza a prueba de dudas. Su claridad expresiva, su certeza verbal, una evidente mesura en la palabra, una sensibilidad trabajada, llena de melancolía y nostalgia..., todo ello han venido a confirmar el hecho de que es la suya una de las voces líricas más singulares y personales que, sin duda, ha podido dar la poesía palentina de la segunda mitad del siglo XX. denuncia sin más, sino que debe plantear como primer objetivo un impulso estético y sensible. Que esta sensibilidad pueda llevar al poeta a percibir y plasmar el sufrimiento de otros es plenamente legítimo, pero no como primer o único objetivo. Consciente de la dificultad que ello supone se pregunta: «¿Qué voluntad poética puede sustraerse a la propagación infecciosa de este germen sin consentir una influencia fatal para la literatura?».

\subsection{Culminación de una etapa}

Aunque el fulgor inicial de Nubis se irá poco a poco apagando, la trayectoria de Fernández Nieto continúa imparable. En estos años tiene lugar la publicación de nuevos poemarios como Aunque es de noche (Palencia, 1947), libro de carácter místico cuyo título procede de San Juan de la Cruz y en el que destaca la presencia de un Dios cercano, casi humano. También Paisaje en sangre viva (Madrid, Musa nueva, 1949), ${ }^{20}$ aunque compuesto en 1947 y enviado igualmente a participar en el Adonais (junto con El cerco de la vida, de Carriedo), aunque con el título de El alma en carne viva. ${ }^{21}$ Se trata de un libro de sonetos dedicados a objetos poéticos concretos tras los que late la presencia de Castilla y que se emparentaría precisamente, en un ámbito cercano, con la tercera sección, «El alma de las cosas», de El cerco de la vida (1947) de Carriedo. ${ }^{22}$ El cultivo de estos textos dedicados a realidades intrascendentales había

\footnotetext{
${ }^{20}$ El poeta, que pese a su avanzada edad y delicado estado de salud, mantiene una excelente vitalidad, señala en correo electrónico, fechado el 19 de diciembre de 2008, al autor de este artículo: «E nombre que yo pretendía era Paisaje en carne viva pero que por alguna mala interpretación me cambiaron por SANGRE. No recuerdo bien, pero es posible que lo enviara [al Adonais] algún año antes con el título de El alma en carne viva. Yo creo que es un conjunto de sonetos de aprendizaje de oficio y nada más».

${ }^{21}$ Los títulos son, en general, muy reveladores: «A una sola nube en el cielo», «A un agua estancada», "A una espiga quebrada», «Al humo de una chimenea», «A un reloj parado», «A una campana sin badajo», «A un ruiseñor herido», «A una abeja dormida», «A un topo muerto», etc.

22 Uno de los sonetos incluido de Paisaje en sangre viva, el titulado "A un clavo en la pared», lo publicaría, como ya hemos dicho, en Nubis, 2 (octubre, 1946). Además de Fernández Nieto y Carriedo se inclinarían por derroteros similares otros miembros de la Peña como Carlos Urueña, con su soneto "A una herradura vieja», o Félix Buisán Cítores con sus sonetos englobados bajo el epígrafe «Poesía de las cosas» y publicados en El Diario Palentino entre 1953 y 1954, según se dice en César Augusto
} 
tenido cierto predicamento en los poetas de Garcilaso, ${ }^{23}$ pero también en Espadaña u otras publicaciones análogas, ${ }^{24}$ por lo que no sorprende encontrar esta práctica en los poetas de Nubis.

Pero, sobre todo, destacaría de los libros de este periodo La muerte aprendida, editado en la Colección Halcón de la revista homónima, en Valladolid en el año 1949. Ahora la libertad estética alcanzada es mucho mayor. Las estructuras poemáticas se sustentan en el uso del heptasílabo y del endecasílabo en unos textos en los que abunda, como el propio título indica, el tono elegíaco. La presencia, tanto de Manrique como de Juan Ramón, autores que cita al inicio, es constante.

En estos años Fernández Nieto seguirá colaborando esporádicamente en la revista Nubis, cuya segunda etapa se inicia en 1950 con diferente formato y apenas cabida para la poesía. Así, en un número extraordinario de octubre de 1951, «Homenaje a los Reyes Católicos», coeditado por la Diputación Palentina, encontramos, junto a textos de Mariano del Mazo Zuazagoitia o Laurentino Herrán, entre otros, una extensa composición en cuartetos alejandrinos y en tres tiempos

Ayuso, «Sobre El cerco de la vida de Gabino-Alejandro Carriedo. Razones para una datación correcta Ayuso, «Sobre El cerco de
PITTM, 74 (2003), p. 384.

23 Recorden silencio de Gerardo Diego, el soneto «A un río helado de Rafael Romero Moliner o el «Sonto a en

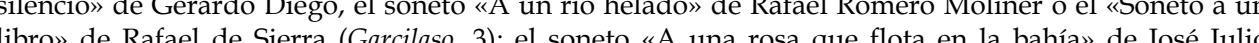
libro» de Rafal de Siera (Garcilso, 3); é Rodriguez (Garcilaso, 8); la uElegia de un árbol seco en privaveras de Lope Mateo (Garcilaso, 3); o e soneto burlesco "A una zambonba estropeada» de Francisco de Loredo (Garcllaso, 20), por citar unos ${ }^{24} \mathrm{En}$ Espadaña tentativos que además guardan relación temática con los poemas de Fernandez Nieto. En Espadaña tenemos en el número 8 (1944) el soneto de Rodrigo F. Carvajal titulado «A un árbo bajo el viento»; o los «Cuatro poemas» de Luis Lopez Anglada, todos ellos sonetos excelentes, incluidos en el núm. 32 (1948), especialmente el titulado «Canta a un pozo en el que se miró su amada». También podriamos incluir en este conjunto "El soneto de la Casa Muerta», de Carlos Edmundo de Ory, dedicado a Chicharro y publicado en la vallisoletana Halcón, 13 (1949), también los «Sonetos al volcán», de Luis López Anglada, en Halcón, 7 (marzo, 1946) o más significativamente el poema (aunque no sea soneto) titulado «Elegía a un árbol caído» de Alfredo de los Cobos, también aparecido en Halcón, 1 (septiembre, 1945). También algunos de los poemas de Manuel Alonso Alcalde reunidos bajo el título «Presencia de las cosas», publicados entre los números 2 y 6 de Halcón, de noviembre de 1945 a marzo del año siguiente. Incluso como antecedente se podría citar el soneto en verso alejandrino de Miguel Hernández titulado «Ascensión de la escoba», publicado también en Halcón, 9 (mayo, 1946) las vicisitudes de lo cotidiano. Es, por ello, muy relevante una insistencia en su esperanza en el futuro, en la vida, en los hombres, una esperanza de tintes religiosos, de una espiritualidad entendida de un modo muy personal. «Creo que mi poesía [...] es esencialmente religiosa», ha llegado a decir.67 También la doble condición del hombre y poeta, la duplicidad manifiesta o, incluso, contradictoria, de esa naturaleza dual, presente en la forma de ver el mundo de ambos y que se hace patente en algunos de los textos de este período. Por otra parte, abundan también los poemas de tono hondamente elegíaco, la temática amorosa, el amor materno-filial, la importancia de la sencillez, de la humildad tantas veces reivindicada en los editoriales, etc.

\section{A MOdo DE CONCLUSIÓN}

Aunque la fructífera experiencia de Rocamador se truncará bruscamente por culpa de la falta de empatía, por decirlo de algún modo, con las autoridades políticas de la dictadura, su obra no se interrumpirá aquí ni mucho menos. Sí podría decirse que esta experiencia servirá al vate palentino para ir consolidando con firmeza una carrera cada vez más firme y asentada. Antes, durante y después vendrán colaboraciones en numerosas revistas poéticas, algunas de ellas de entre las más renombradas del momento. Tal es el caso de Espadaña (1944, León), Verbo (Alicante, 1946), El molino de papel (Cuenca, 1954), Quaderna vía (Madrid, 1961), Poesías (Zaragoza, 1962), Aquí el alma navega (Cuenca, 1970)...

Con los años verán la luz también nuevos poemarios en los que pondrá en práctica el aprendizaje realizado a través de estas dos publicaciones. Serán libros como Villancicos para zambomba y transistor (Palencia, 1969), Galería intima (Colección El toro de granito, Ávila, 1972), La claridad compartida (Editorial Clara, Bilbao, 1972), Memoria del amor (Colección Rocamador, Palencia, 1973), La nieve (Colección Provincia, León, 1974), Poemas de amor de cada día (Colección Rocamador, Palencia, ${ }^{67} \mathrm{Ibidem}$. 
auténticamente constructivo que mueve al hombre hacia Dios».63 Para ellos, «sin duda alguna encierra más valentía el hecho de enfrentarse con un tema tan humano y a la vez tan manido como es el amoroso, que hacerlo con temas que por actualidad o esnobismo pueden interesarnos más». ${ }^{4}$

\subsection{Aportación de José María Fernández Nieto}

En los tres primeros números de Rocamador se publicará una sección que, bajo el título de «Álbum de cuentos poéticos», recoge algunas muestras de relato breve de nuestro poeta. Son textos en los que se retratan personajes sencillos, ingenuos, un tanto angelicales, pues la temática de estos relatos, más que de orden narrativo, será de orden estrictamente poético. Nos hablan de la eternidad, pero también de la desorientación o la sensación de extrañamiento de unos seres que, como los poetas, habitan en un mundo en el que de alguna manera se sienten ajenos.

Pero si en los relatos de José María Fernández Nieto percibimos la presencia de una serie de temas recurrentes que, a menudo, son caros al autor, en los poemas publicados en Rocamador encontraremos también algunos de los aspectos presentes en el conjunto de su obra, así como en los libros de esos años, ${ }^{65}$ coincidiendo en gran medida con muchas de estas ideas expuestas en los editoriales, y que merecerían un análisis más detallado. Si bien, como el propio poeta ha declarado, es más importante, a la hora de hablar de su lírica, hablar del «cómo» y no del «qué», en referencia a este último podría decirse que los temas principales de su producción serían: «el amor, el hombre actual, los problemas sociales, la muerte, la inquietud religiosa»,66 y en esto no van a ser diferentes las composiciones incluidas en la revista. Éstas suelen estar marcadas por una actitud positiva, optimista y vital ante

\section{Ibidem}

64 «Poesía amorosa», Rocamador, 19 (verano, 1960), pp. 1-2.

65 A orillas del Carrión (Palencia, 1957), La Trébede (Colección Alrededor de la mesa, Bilbao, 1961), Capital de provincia (Colección Ababol, Madrid, 1961), Un hombre llamado José (Colección Ágora, S. Sebastián, 1965), Buzón de alcance (Editorial Club de Prensa, Barcelona, 1966).

66 «Poética» en Marcelino García Velasco (ed.), op. cit., p. 70. firmada por nuestro poeta y que llevaba por título «Loa Nupcial de los Reyes Católicos».

Nubis (ahora sin subtítulo) tratará de resucitar con el antiguo formato en 1957, comandada esta vez por Mariano del Mazo, quien ejerce las funciones de director. Se intentará, al mismo tiempo, retomar el planteamiento inicial, como se dice en el editorial de las primeras páginas, de abrir Palencia hacia el exterior para «no se encierre en sí misma».25 Por ello, no es difícil apreciar que, tanto en formato como en contenidos, la revista no ha sufrido variaciones considerables. En ella se percibe todavía la firma de algunos antiguos «nubianos» como Ruy Planter, Félix Buisán, Antonio del Mazo... También de nuevas incorporaciones como el futuro crítico de arte Santiago Amón o colaboraciones externas, en lo que a poesía se refiere, de autores como Francisco Pino ${ }^{26}$ o Mario Ángel Marrodán. ${ }^{27}$

Sin embargo ahora, la ausencia de Fernández Nieto es significativa. La razón habría que buscarla en el hecho de que llevaba ya dos años embarcado en una nueva aventura poética, la revista Rocamador, junto a Marcelino García Velasco, ${ }^{28}$ quien en el primer número del nuevo Nubis publica una hermosa «Carta a Juan Ramón», que el año anterior había recibido el Premio Nobel. En ella el joven poeta lo advierte:

$$
\begin{aligned}
& \text { No vuelvas a Moguer, te digo y me despido, } \\
& \text { Platero murió, ya sabes cómo. } \\
& \text { Ni la luz de Moguer es ya tan blanca, } \\
& \text { ni el silencio del puerto tan marinero. }
\end{aligned}
$$

Podría decirse que la «Peña Nubis» fue, en su conjunto, una iniciativa cargada de ilusión y buenas intenciones que, sin embargo, decaería, entre otras razones, por

${ }^{25}$ Texto sin título y sin firma. Nubis, 1 (enero, 1957), s. p., aunque 1.

${ }^{26}$ En el número Nubis, 2 (febrero, 1957), s. p., aunque 10, leemos el poema «La pila» de su libro Vida de San Pedro Regalado, sueño, Valladolid, Meseta, 1956. También en las dos páginas siguientes Santiago Amón dedicará un extenso artículo a este libro.

27 En Nubis, 2 (febrero, 1957), s. p., aunque 9, leemos su soneto religioso «Apenada presencia».

${ }^{28}$ También este, entonces jovencísimo, poeta había escrito una composición dedicada al Greco en un pequeño suplemento que acompañaba al número 2 de la nueva Nubis, en 1957. 
la disparidad de criterios de sus integrantes. ${ }^{29}$ Esta diversidad había sido denunciada ya por Carriedo en el número 3 de la primera etapa de la revista (diciembre de 1946) en su artículo «Tendencias de la Peña o neomelopea de los ismos» (p. 23), artículo incluido en la sección «El pulso de la Peña». Allí habla de «clasicistas», «pletoristas» (por él comandados), «modernistas», «humoristas», «moderados del centro», «independientes»... Aunque al final del artículo juzga como positiva esa enorme variedad, tampoco duda en calificar con extrema lucidez a todos ellos de «círculos concéntricos», «consecuencia inevitable de la manera de ser de cada uno». Esta diversidad se percibía también en la cantidad de boletines «paralelos», generalmente mecanografiados, que se hacían eco de las divisiones internas, como La Puya, ${ }^{30}$ del que es autor el propio Fernández Nieto, Medianoche (de Antonio del Mazo), Reflejos (de Jesús Unciti), Avance (de Mariano del Mazo), etc. También en este sentido ha señalado Marcelino García Velasco: «Todos sus colaboradores tenían alma de director». ${ }^{31}$

Finalmente «Nubis», como institución de vida efímera, dejará la simiente necesaria para que en 1949 surja el Centro de Estudios Palentinos o Institución Tello Téllez de Meneses, que aunaba el impulso de «Nubis» al de un «Instituto Palentino de Estudios e Iniciativas» que habría surgido con escasa proyección unos años antes, el 30 de junio de 1941, vinculado a la Diputación Provincial.

${ }^{29}$ Aunque algunas iniciativas propuestas desde el núcleo de la institución salieron adelante, como hemos visto, otras resultarán fallidas, tal vez por requerir una infraestructura y una continuidad no siempre fáciles de conseguir. Entre ellas está la organización de producciones teatrales, la creación de la «Cátedra Nubis» o la publicación de un libro de greguerías y de una novela colectiva.

${ }^{30}$ Según él mismo declara en Fernando Presa González, op. cit., p. 27.

${ }^{31}$ Verbo, 32 (enero-marzo, 1963), p. 39, aunque cito a través de Fernando Presa González, op. cit., p. 128 es religiosa. Buscará unas veces a Dios en la Belleza». ${ }^{58}$ Para añadir a continuación: «Se volverá otras veces, con íntimo desgarrón, hacia el centro humeante del misterio, llegará quizá a la blasfemia». Sobre el carácter trascendente de la poesía regresan a menudo,59 aunque lamentando en alguna ocasión que la lírica de su tiempo, en lugar de dar respuestas, sea «una constante interrogación, una continua siembra de dudas existenciales».60

d) Actitud política. Para ellos, una cosa es la actitud vital del hombre y otra la del poeta, y ambas deben ir desligadas, no debiendo estar la segunda al servicio de la primera, pues haría peligrar la calidad de la obra artística. Sin embargo, no hay duda de que «el poeta debe y tiene que cantar a pleno pulmón, sin bozal de censuras mezquinas, sin cortapisas ni ataduras. De cada poema», continúan, «puede desprenderse, a veces, una actitud incluso política en lo que la política tiene de contacto con la dimensión espiritual del hombre». ${ }^{61}$ Sin embargo, al mismo tiempo, consideran que la poesía «no puede ser cauce de resentimientos ni arma de insultos ni flecha envenenada de revanchas ideológicas», pues «la Poesía si no es un instrumento positivo para el hombre, si es un arma de destrucción no vale la pena sentirla y escribirla». 62

e) Importancia de la temática amorosa. Por eso consideran que «el núcleo esencial y auténtico de la poesía debe de ser el Amor que es el elemento

${ }^{58}$ Dámaso Alonso, «En busca de Dios», Poetas españoles contemporáneos, Madrid, Gredos, 1958, pp. 375 y ss.

59 Por ejemplo nos dirán que la «Poesía es una proyección del hombre hacia lo trascendente», pues «hay en el verso un pálpito de lo desconocido, como un atisbo de sondeos trascendentes». «Función de la poesía», Rocamador, 14 (invierno, 1959), pp. 1-2.

${ }^{61} \mathrm{I}$ «Poesía y política», Rocamador, 15 (primavera, 1959), pp. 1-2. De nuevo se trata de justificar la publicación de textos de autores tal vez un tanto «incómodos» para el régimen, tal es el caso de Vallejo y Neruda «cuya etiología política no desconocíamos», dirán, pero cuyos textos seleccionados «no iban etiquetados por una temática política».

62 «Amor y poesía», Rocamador, 20 (otoño, 1960), pp. 1-2.

LECTURA Y SIGNO, 4 (2009), pp. 189-212 
a) Función estética: «La poesía», afirman, «no es una religión, no es una medianera de la filosofía», su misión es «estética, formativa de almas».53 Pero, al mismo tiempo, consideran que tampoco debe caerse en la facilidad compositiva y retórica, pues el arte poético no necesita de esa claridad lógica, «casi matemática», ${ }^{4}$ matizan, que algunos pretenden achacarle, tal vez en clara referencia al descuido estético preconizado por la lírica social.

b) Subjetividad y misterio: La poesía será, pues, «la expresión íntima subjetiva del hombre» $y$, por lo tanto, como expresión de lo inefable de la naturaleza humana, debe ser misteriosa, cargada de sugerencia, pero, al mismo tiempo, invitar a la indagación íntima, a la introspección, a la reflexión interior. Acaso el hombre, se preguntan, «¿no es una incógnita, un problema en sí mismo?». Pues el fin de la poesía de hoy es, para ellos, «descifrar esa incógnita humana».55

c) Preocupación trascendente: Así, dirán, más que «religiosa», como algunos la han calificado, es necesaria una "poesía de preocupación trascendente, y de ahí», nos dirá el editorial de turno, «su misterio trasformado en oscuridad al quererse expresar». Esto explicaría, continúan, «esas constantes alusiones a Dios en la poesía moderna que son como asideros, como puntos de apoyo que el poeta quiere buscar para expresarse a sí mismo».56 Ello no implica un confesionalismo marcado ni mucho menos, sino la búsqueda constante de la esencia humana y de su lado más espiritual. Se trataría de lo que, en otro editorial, 57 denominan poemas con «sentimiento religioso», frente a los que califican de «piadosos», coincidiendo así, de alguna manera, con Dámaso Alonso, a quien aluden y que en esos mismos años señalaba: «Toda poesía

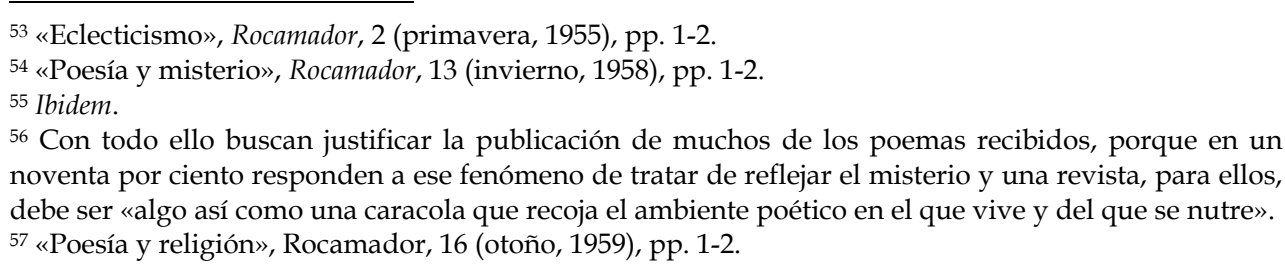

${ }^{56}$ Con todo ello buscan justificar la publicación de muchos de los poemas recibidos, porque en un noventa por ciento responden a ese fenómeno de tratar de reflejar el misterio y una revista, para ellos, debe ser «algo así como una caracola que recoja el ambiente poético en el que vive y del que se nutre». 57 «Poesía y religión», Rocamador, 16 (otoño, 1959), pp. 1-2

\section{ROCAMADOR O EL VALOR DEL IMPULSO POÉTICO}

\subsection{Creación de Rocamador}

La revista poética Rocamador surgirá a partir del feliz encuentro entre los dos poetas, Fernández Nieto y García Velasco, y contará en su trayectoria con tres etapas claramente delimitadas. Las diferencias entre ellas serán visibles incluso en el propio formato de la publicación que sufrirá algunos cambios.

La primera abarca desde el número inaugural (enero, 1955), hasta el décimo tercero (invierno, 1958). En este período la revista cuenta con una subvención oficial de la Diputación de Palencia. Ello obliga a que conste en el interior de la portada un lema que dice que está editada por «El Grupo de Poesía del Círculo Cultural del Movimiento». Los ocho primeros números irán ilustrados, tanto en la portada como en las páginas interiores. La portada, así como todos los dibujos del número inicial, fueron realizados por Oliva. La presencia de ilustraciones realizadas por diversos colaboradores se mantendrá hasta el número 14 , al inicio de la segunda etapa. ${ }^{32}$

En la portada en color, junto al nombre de la revista, encontramos una columna y en el centro de la misma una viñeta con una ilustración de la ermita palentina de Rocamador, ilustración que se mantendrá en los dos primeros números siendo sustituida, hasta el octavo, por un dibujo abstracto que varía casi en cada nuevo número.

Los cambios habidos en la Diputación Provincial obligan a una alteración del formato que supondrá, como consecuencia más inmediata, que el tamaño de Rocamador se reduzca a la mitad. Ello afecta, sin ir más lejos, a la propia portada, pues ahora el rótulo con el nombre, que antes iba en la base, la atravesará en diagonal. La

32 Entre los autores de esas ilustraciones podemos encontrar a Carmen Saldaña, $\mathrm{M}^{\mathrm{a}}$ Luisa Madrilley (entonces esposa de Ángel Crespo y colaboradora de revistas como Deucalión, El Pájaro de Paja y Doña Endrina), Marcelino García Velasco, Rafael Millán, la niña $\mathrm{M}^{\mathrm{a}}$ Luz Muelas (hija de Federico Muelas), Michel Rioufol, Mariano Torres, Ángel Crespo, Sino Granja, J. Valle-Inclán o Pesqueira Salgado.

LECTURA Y SIGNO, 4 (2009), pp. 189-212 
viñeta de carácter abstracto irá colocada sobre él. Los colores utilizados serán solamente el negro y el verde. Si hasta entonces el escudo del Movimiento aparecía discretamente en la parte interior, a partir de este momento, en los números del $10 \mathrm{al}$ 13, ambos incluidos, ocupará el centro de la contraportada debido a una decisión totalmente extraliteraria tomada por el nuevo presidente de la Diputación, responsable a su vez de este nuevo formato que con el que buscaba abaratar costes de una publicación que no se consideraba como algo imprescindible, ni mucho menos. ${ }^{33}$ A partir del número 6 de esta etapa figurará, junto a Fernández Nieto como director, Marcelino García Velasco como subdirector.

Durante el segundo período, que abarcará del número 14 (invierno, 1959) al 32 (invierno, 1963), el sustento de la revista será exclusivamente privado, por lo que no sólo desaparece el escudo oficial de la contraportada, sino que, incluso, todas las ilustraciones, pues ello sirve de nuevo para reducir costes, pues ya no se cuenta para editarla con el respaldo económico de una institución poderosa como puede ser una Diputación Provincial. Esta etapa, libre de anteriores servidumbres, terminará sin embargo con un editorial (n. $\left.{ }^{\circ} 32\right)$ en el que se advierte de que, a partir del número 33 y siguientes, se cobrará subscripción, aunque ello, aseguran, no les hará perder ni un ápice de independencia a la hora de escoger los textos a publicar o de realizar las críticas. $^{34}$

A partir, pues, de esta tercera etapa, desde el número 33 (septiembre, 1964) al 45 (con fecha del 31 de julio de 1968), la revista contará para su sustento con suscripciones. Reaparece ahora el dibujo de portada.

El cierre abrupto de la publicación, en apenas cuatro años tras el inicio de este nuevo período, se deberá a problemas con las autoridades tal y como ha explicado Marcelino García Velasco:

33 Ver de nuevo Fernando Presa González, op. cit., pp. 133 y ss.

34 «Despedida, saludo y más cosas», Rocamador, 32 (invierno, 1963), s.p., aunque pp. 1-2. incluso descubre caminos y cierra otros».50 Para ellos algunos sectores de la crítica actual y de los jurados de premios literarios presentan una serie de problemas como son la preferencia por el hermetismo, la falta de eclecticismo en el gusto o cierta tendenciosidad, la excesiva preferencia por temáticas propias de la época (como la lírica social) frente a otras posibles, o el, para ellos injusto, rechazo de la poesía tendente a lo que consideran «clasicismo», es decir, una poesía sustentada en los valores de la tradición literaria heredada del Romanticismo.

Aunque «el valor permanente de un libro, de un poeta no lo podrán catalogar ni los premios, ni los críticos», aseguran que «los Premios establecidos estimulan a los poetas a escribir más, hasta el punto de que si no fuera por ellos la producción poética posiblemente quedaría reducida a la décima parte».51 Así, en el número siguiente harán pública la convocatoria del Premio Rocamador de Poesía, para menores de 30 años. $^{52}$

\subsection{Rocamador y el Arte Poético}

Resulta interesante también la visión de la poesía, que se plasma a lo largo de los editoriales de diferentes números, pues se nutren de apreciaciones que podrían leerse hoy a modo de Arte Poética. Aunque cabe decir que, en más de una ocasión, algunos de estos textos habrían de surgir como justificación por la publicación de obra perteneciente a poetas que, con probabilidad, no siempre habían de ser bien acogidos en el ambiente poético provinciano, tal es el caso de Vallejo o Neruda.

Sea como fuere, para ellos, en fin, la poesía tendría características que podríamos, a grandes rasgos, resumir en las siguientes:

50 «Crítica poética», Rocamador, 9 (invierno, 1957), pp. 1-2. También Rocamador recibirá ataques por sus críticas, pues hay quien les achaca que comenten muy brevemente demasiados libros, como leemos en «Crítica», Rocamador, 35 (noviembre, 1964), pp. 1-2.

51 «Premios», Rocamador, 29 (primavera, 1963), s. p., aunque pp. 1-2.

52 «Premio Rocamador de Poesía», Rocamador, 31 (otoño, 1963), pp. 1-2.

LECTURA Y SIGNO, 4 (2009), pp. 189-212 
«valores esenciales y transcendentes». ${ }^{41}$ Sin embargo, no dejan de criticar lo que consideran dificultad, elitismo o el hermetismo de algunos autores, que exige una «preparación especial que no sea específicamente espiritual».42 En esta vertiente incluirían a Ezra Pound, cuyos cantos no son más que un «cruce frustrado», nos dirán, «de erudición y de las barbas del abuelo Whitman».43 Alaban, sin embargo, a Dag Hammarskjöld, sueco, segundo secretario general de la ONU y Premio Nobel de la Paz (póstumo) en 1961 y de quien en 1966 publicó la editorial Seix Barral su libro de prosas y poemas Señales en el camino. ${ }^{44}$

Su valoración de los poetas patrios se plantea, sin embargo, sin fisuras, independientemente de la dificultad de estos. Así, no faltarán alabanzas a Ramón de Garciasol, ${ }^{45}$ a Vicente Aleixandre ${ }^{46}$ o a Juan Ramón Jiménez a propósito de la concesión del Nobel en 1956. El de Moguer es para ellos «un poeta muy superior si se quiere a los de su época, quintaesenciado, pero dentro de la línea del vanguardismo más avanzado».47 Tampoco dejan de admirar a Antonio Machado, a quien homenajean en el 25 aniversario de su muerte y de quien ensalzan su «figura cabalmente humana», pues en él «confluyen todos los caminos de la Poesía».48 Lo mismo sucede con Unamuno, al que consideran «ante todo un poeta». 49

Otro de los temas frecuentes en sus editoriales será el de la crítica poética, pues cuando deja de lado cualquier sectarismo es necesaria porque «enseña, corrige,

${ }^{41}$ «Saint-Jhon Perse», Rocamador, 21 (invierno, 1960), pp. 1-2.

Ibidem

« «Poesía y Política I. El fenómeno Ezra Pound (2)», Rocamador, 41 (abril, 1966), pp. 1-2 y 24

44 «Poesía y política II. Dag Hammarsjold y sus Señales en el camino», Rocamador, 42 (30-VI-1966), pp. $1-2$ y 24.

45 «Una poesía humana», Rocamador, 45 (31-VII-1968), pp. 1-2 y 16

${ }^{46}$ «Fuentealeixandre», Rocamador, 22 (primavera, 1961), pp. 1-2.

47 «Premio Nobel a la poesía española», Rocamador, 8 (otoño, 1956), pp. 1-2.

48 «La voz de Antonio Machado», Rocamador, 33 (septiembre, 1964), pp. 1-2. Sobre la figura de

Machado volverán en «Otra vez Don Antonio», Rocamador, 44 (30-V-1968), pp. 1-2 y 16.

49 «Unamuno desde aquí», Rocamador, 34 (octubre, 1964), pp. 3-4.
«Creo que, para sonrojo de las instituciones oficiales, debo declarar que esta tarea de lanzar al aire nacional revista v colección de libros, se debió al sacrificio económico de un poeta, José María Fernández Nieto - compensado con el fervor, supuesto, del señor Director General de Información de entonces, Ministerio de Información y Turismo, que propició la desaparición de la revista por haber incurrido el mecenas en el delito supuestamente ¿insultante?, de ofrecer criterios distintos a los de la Dirección General en un Congreso de Escritores en San Sebastián - que se gastaba en este menester lo que ganaba en los juegos florales y que - velay, lo absurdo de la presunción de culpabilidad sin conocer a la madre del cordero $-[\ldots] » .35$

\subsection{Los editoriales de Rocamador}

Leídos en su conjunto y en la distancia, los editoriales de Rocamador resultan hoy un claro y, en ocasiones controvertido, manifiesto poético. Pero son también reflejo del tiempo en el que se escribieron, un tiempo en el que no sólo había que lidiar con la censura, sino también con las dificultades que suponía, desde cualquier ciudad de provincias de un país que vivía bajo una malhadada dictadura, acceder a la ingente cantidad de publicaciones que circulaban por el mundo literario. A esto hay que añadir otra dificultad más, la de difundir su propio legado desde una postura de franca independencia y libertad que pudiera, como sin duda ha ocurrido, ser malinterpretada. ${ }^{36}$ En el fondo, más que inclinarse hacia una opción política o tendenciosa, estos editoriales mostrarán un peculiar modo de entender el hecho poético, discutible si se quiere, pero personal y coherente, sobre todo con la trayectoria de uno de los poetas fundadores, el que aquí nos ocupa.

Lo que no puede negarse en absoluto es que de su falta de tendenciosidad o partidismo nos hablan más que explícitamente las páginas de la revista. Páginas por las que desfilan nombres tan diferentes entre sí como: Carriedo, Crespo, Celaya,

\footnotetext{
35 Marcelino García Velasco (ed.), 19 poetas. Antología de la poesía palentina del siglo XX, Palencia, Aretusa, 2000, p. 18

${ }^{36}$ Sin estar totalmente faltas de razón, algunas apreciaciones realizadas por Fanny Rubio (op. cit., pp. 308 y ss.) resultan hoy día un tanto tajantes. Aunque es acertado el juicio de considerarla «abanderada contra una poesía comprometida», resulta a todas luces excesiva la calificación de Rocamador como «revista doctrinaria, confesional». Si bien es cierto, que esta autora valora el mérito que corresponde a Rocamador de no convertirse «en reducto de grupo, abriendo sus páginas a quienes podía contravenir
} las máximas teóricas de las editoriales de la revista».

LECTURA Y SIGNO, 4 (2009), pp. 189-212 
Ángela Figuera, Aleixandre, J. A. Goytisolo, Manuel Pinillos, José Miguel Ullán, Pere Gimferrer, Alfonso Canales, Félix Grande, Ramón de Garciasol, Pablo Neruda o César Vallejo. Amén de los poetas palentinos y los tres fundadores.

En el heterogéneo conjunto de opiniones que dan forma a estos editoriales se trata todo tipo de temas: gusto por el eclecticismo, crítica a aquellas revistas que fomentan el amiguismo o el sectarismo poéticos y la tendencia de algunos autores a dejarse llevar por el influjo de las nuevas corrientes sin reflexionar sobre ello o sin cuestionarlas.

En este sentido «Nuestra presencia», el editorial que abre el primer número resulta, pese a algunas contradicciones, especialmente significativo. Aunque en números sucesivos irán mostrando sus filias y fobias, ello no impide que se mantenga en todo momento, a lo largo de la trayectoria de la publicación, esa defensa del «eclecticismo» aludida, como dirán en el número 2, así como una actitud abierta y tolerante, la misma que ahora proclaman: «No tenemos ningún postulado, ningún mensaje poético», «queremos que en nuestras páginas quepa, en toda su variedad, la flora poética actual», a la que ellos aportarán «el sello mismo de los poetas palentinos». Aunque entran en contradicción con lo que harán posteriormente al anunciar que «no habrá crítica de libros» (algo que no se cumple a partir del número 3), pero sí «recensión de los que recibamos», mantendrán siempre una saludable coherencia al cuestionar a las revistas que, según ellos, «hacen círculo cerrado de la Poesía» con sus críticas, así como a los poetas que «elaboran su proclama o su pregón poético» antes que su obra. También la «superabundancia actual» de libros y revistas, culpable del «retoricismo poético».

Sobre algunos de estos temas volverán en editoriales posteriores. Por ejemplo cuando critican la «despersonalización» de algunos autores que se dejan arrastrar por las corrientes del momento, pues la poesía debería cantarse, nos dirán, «como salga la voz, sin engolarla con el recuerdo del último cantor de moda». ${ }^{37}$ El vate debe buscar su propia voz, una voz ajena a los dictados de la crítica, ${ }^{38}$ debe acercarse a su obra con humildad, sin alardes, «calladamente», «dándonos en ella como si estuviéramos dando una limosna de espíritu, pero seriamente, como hombres y no como locos o como dioses», evitando ese elitismo que ha hecho que muchos poetas sólo escriban para otros poetas y para los críticos (los cuales a su vez también son poetas). ${ }^{39}$ Todo ello, vendrán a decir, inevitablemente ha acarreado un considerable descenso en el número de lectores, pues el lector ansiado ya no es sólo una persona sensible, sino alguien con una amplia formación poética y cultural.

\subsection{La poesía española, la crítica, las revistas y premios}

Se observa, en general, una preferencia bastante clara por los autores en lengua castellana frente a los extranjeros. En el fondo, consecuencia de una actitud vital presente en la España del medio siglo, cerrada sobre sí misma y con una necesidad de autoafirmación que tendía a condenar lo foráneo.

Aún así, de la poesía argentina destacarán discretamente su «honda preocupación por los problemas del hombre actual desde muy variados ángulos de vista».40 También, aunque celebran el Nobel otorgado al francés Saint-Jhon Perse en 1960, pues ello, así como la concesión el año anterior al italiano Salvatore Quasimodo, supone el reconocimiento a nivel internacional de la Poesía «como la más alta jerarquía intelectual y espiritual», sobre todo esa «poesía quintaesenciada», «la que tiene», dirán, «sustancialidad suficiente para no confundirse con esa otra poesía rayana en el espectáculo o en la especulación literaria», la que tiene, insisten,

\footnotetext{
37 «Eclecticismo», Rocamador, 2 (primavera, 1955), pp. 1-2.

38 «Crítica poética», Rocamador, 9 (invierno, 1957), pp. 1-2.

$39 \mathrm{Ibidem}$. Volverán sobre ello al decir en alguna ocasión que se hace más «poesía poética que poesía humana». «Círculo cerrado», Rocamador, 28 (invierno, 1962), s. p., aunque pp. 1-2.

40 «Poesía argentina actual», Rocamador, 39 (septiembre, 1965), p. 1.
} 
generación de los 50, a la que se la ha adscrito por la naturaleza de sus intertextos: Perse, Trakl, Lorca, los surrealistas, etc. ${ }^{2}$ La lírica del asturiano, criado en Castilla, se extiende desde el recuerdo melancólico y frustrado de una infancia triste, marcada por la vesania de la guerra civil española, hasta la muerte. Como él mismo nos dice «[...] la memoria es siempre conciencia de pérdida [...], de consunción del tiempo correspondiente a mi vida y, por esto mismo, conciencia de ir hacia la muerte». ${ }^{3}$ Ese óbito, con mucho escepticismo, le gustaría que se convirtiera en un renacimiento moral del ser humano en un pasado ideal más allá de la historia. De todos modos, no se establece un programa social, sino uno simplemente regenerador en lo ético y moral. Nos encontramos ante un poeta laico que es deudor de una larga tradición ontológica de autores que fueron en busca de un pasado inexistente y depurado para tratar de reformar desde la lírica y la interiorización la injusta historia que les tocó vivir. Estamos en la era de la «indetermanencia» según Ihab Hassan. ${ }^{4}$ Este crítico propone una mirada sin ilusión personal ni colectiva y con mucha indeterminación hacia el interior del ser humano, lo inmanente. Ella pretende superar una obvia crisis de valores de lo histórico en unos siglos XX y XXI marcados por la ruindad de las luchas por el poder y sus devastadores efectos. Pedro Serrano lo resume así con respecto a Gamoneda: «Sus poemas son fotografías exactas de la miseria y lo inmisericorde, y de una voluntad de vida que florece a pesar de la opresión y en la opresión». 5

Así pues, su lírica dialoga con una secuencia literaria que va en busca del origen del ser y de la vida como evasión de una realidad agria y como intento utópico de redención humana. En su naturaleza está el aliento postromántico en pos

2 Estas filiaciones se encuentran en L. García Jambrina (ed.), La promoción poética de los 50. Ángel González, José Manuel Caballero Bonald, Carlos Barral, José Agustín Goytisolo, Jaime Gil de Biedma, José Ángel Valente, Francisco Brines, Claudio Rodríguez, Madrid, Espasa Calpe, Colección Austral, 2000, p. 24.

${ }^{3}$ En A. Gamoneda, El cuerpo de los símbolos, Murcia: Huerga y Fierro, 1997, p. 24

4 En The Postmodern Turn: Essays in Postmodern Theory and Culture, Columbus, Ohio State University 4 En The Postmoder
Press, 1987, p. 91.

${ }^{5}$ En «Gamoneda: la escasez y la necesidad», Letras Libres, 84 (2005), p. 85.
Ballesteros sigue, en cierto modo, la singladura de la narrativa isabelina en general, muy circunspecta a la hora de ofrecer detalles y con un sentido bastante inglés del equilibrio narrativo, de lo que debe ser y lo que no debe ser desde un punto de vista escritural. Pero es obvio que no todo el proceso posee una aceleración similar. La novela va adquiriendo, a medida que avanza, una gran fuerza literaria (iría de menor a mayor): «El avance de la narración va concatenando los capítulos de manera que unos aclaran, continúan o refuerzan lo tratado en los otros».7

Si al principio podemos observar ciertos titubeos, a partir de la entrada en liza de Ann Northom, la amante de Thomas, la novela adquiere un inusitado interés y parece que el narrador se contagia de esa situación novelesca: «Es a partir de ahora cuando empezamos a conocer mejor la personalidad de De Quincey». ${ }^{8}$

Este hecho también va a ser destacado por Ruiz Garzón, que afirma en torno a ello lo siguiente: «La novela exhibe su mejor tono en las documentadas recreaciones de la amante, Ann, y la esposa, una entregada Margareth Simpson, cuya voz transmite con sosiego las dolencias y adicciones del autor».9

Sobre todo por el carácter libresco de ésta y su impronta literaria. Este hecho precedente entendemos que sucede porque existe una necesidad en los capítulos precedentes de crear la imagen familiar encarnada por el padre de Thomas y su madre, Elisabeth Penson, pero es una necesidad, no una concentración de intensidades para el escritor.

En realidad, Elisabeth de lo que menos habla es de Thomas. Ofrece más bien una visión familiar general, limitándose a hablar del señor Flearty, el tutor de Thomas, y de sí misma: su espíritu inconformista, su carácter soñador... Se trata de una persona culta, intelectualizada, que ama la poesía.

A. Moreno Ayora, «Los últimos días de Thomas de Quincey», El maquinista de la Generación, 13, (2007), p. 62

8 Ibidem.

${ }^{9}$ R. Ruiz Garzón, op. cit.

LECTURA Y SIGNO, 4 (2009), pp. 213-222 
A través de un proceso organizativo fragmentario, en breves y raudas escenas, Ballesteros va de un tema a otro con la obsesión de que el exceso no sea una incontinencia innecesaria y sí la creación de los perfiles adecuados. Es como si estuviera un tanto inquieto por saber zanjar a tiempo la escena o la situación. Y de hecho, como si fuera partícipe de las ideas del escritor, dirá Elisabeth Penson «Quiero acelerar la historia de estos hechos que me producen inquietud y zozobra».10

Sólo al final del capítulo hará algunas reflexiones sobre Thomas y enumerará algunas ideas o rasgos de su carácter, como cuando afirma que lo dominaba una inquietud incontenible que le producía pesadillas y vómitos cuando su padre, de pequeño, le contaba terribles historias. Pero también nos advierte de que

Era un niño retraído y solitario. También débil y esquivo. Estaba siempre con Jane y Elisabeth que jugaban con él como se juega con un juguete muy querido o con un cachorrillo de perro. Con suavidad y tiento. Cariñosamente [...] Thomas era un niño triste y feliz. Muy pronto advertí que tenía las manos más bellas del mundo: finas, elegantes y presurosas y me llenaba de orgullo su frente altiva, plean de volunta, de entereza y de aires soñadores. ${ }^{11}$

Incluso era muy temeroso de la autoridad del padre, meticuloso y lento, poco hablador, fácil en su comportamiento pero nunca llega a producir paz, tranquilidad o reposo.

La exposición del padre en el capítulo segundo aportaría también poca información sobre Thomas de Quincey. Sabemos que le cuenta historias terribles a su hijo, como la que interpola de Sofrás, con intención de transformar a su débil hijo en un ser fuerte:

El padre será el encargado de desvelarnos la visión masculina de la necesidad y obligación de tomar decisiones firmes y de tener una voluntad infatigable, su doble moral dividida entre el amor respetuoso y a veces hasta tierno y cómplice con su esposa y la secreta preferencia por el fetichismo sexual, además de su animadversión hacia el carácter soñador y enfermizo del hijo a quien educa en la superación de los miedos

${ }^{10}$ R. Ballesteros, Los últimos días de Thomas de Quincey, Barcelona, DVD, 2006, p. 30.

${ }^{11}$ R. Ballesteros, op. cit., pp. 36-37.

\section{LA POÉTICA DE ANTONIO GAMONEDA: EL REFERENTE ESOTÉRICO*}

\author{
JORGE MACHÍN LUCAS \\ The University of Winnipeg
}

\section{INTRODUCCIÓN}

«¿Que cuál es el espacio de la Lírica? Pues, es el espacio comprendido entre mi memoria poética, el extremo de memoria poética, y el extremo de mi temor, de mi

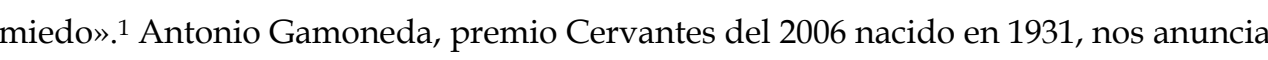
con aquel extracto el itinerario ideológico que va a seguir su cada vez más existencialista y oscura poesía. Esta ha sido separada por la mayoría de la crítica de la

Recibido: 08-04-2008 Aceptado: 09-06-2008

En F. Martínez García, Gamoneda, una poética temporalizada en el espacio leonés, León, Universidad d León, 1991, p. 34 
muchos casos, pero también nuevos hallazgos, sin fusionar, empero, la experiencia con la culturalidad. ${ }^{29}$ mediante relatos espectrales que dejarían huella en la posterior vida literaria y personal del escritor.12

Nos ayuda a comprender también las ideas del escritor a partir de las conservadoras del padre. De hecho tuvo nuestro escritor ideas conservadoras, aunque su creación fuera arriesgada y atrevida. La fragmentariedad y la interpolación se hace dueña de este capítulo con la «historia amorosa» de su padre y la señorita O`Learty, con la que vive un idilio de voyeur:

Yo no tocaba nada, sólo miraba... Y abría sus piernas. El olor a cenizas de su sexo. La savia salobre que germinaba allí. La rosa bulba que bullía [...] Y el cuerpo de la chica desaparecía detrás de la puertecilla; y entonces, sí, ahora me miraba a los ojos suplicándome algo que nunca supe descubrir. ${ }^{13}$

El tercer personaje-narrador de los acontecimientos será una mujer: su amante. Thomas conocerá a Ann Northom en la calle. Era una mujer del arroyo a la que se le fueron muriendo sus diez hermanos. Pero frente al idílico amor que él sintió por ella; Ann, en realidad, de quien estaba enamorada era del portugués Antonio Andrade; Thomas le importaba poco. Hacia el final del capítulo lo dirá con líricas y bellas palabras: «¿Qué nos unía en verdad? Mi amargura con su desamparo. Mi soledad con su ansia de vida. Mi final con su principio». ${ }^{14}$

Efectivamente, una mujer que venía de vuelta y un hombre que comenzaba a vivir. Es la visión que nos ofrece esta mujer soñadora que entrará en un internado en Londres del que Ballesteros reproduce los once artículos que lo gobernaban: «Dentro de mí se agotaba una especie de serenidad que inexplicablemente había mantenido en el alma». ${ }^{15}$

Sobre Thomas, como su padre y su madre anteriormente, apenas si ofrece

29 Según Ángel L. Prieto de Paula, «La progresión culturalista viene determinada por el avance en la desvinculación entre quien escribe y la "experiencia" - que no tiene por qué ser personal - escrita. En el grado máximo de esta desvinculación, el sentimiento personal puede desaparecer de la superficie del poema, como cuando la voz del autor queda irreconocible en la cascada de otras voces o realidades culturales heterogéneas: la propia pluralidad de registros emborracha con su mezcolanza la nitidez del yo, tal como sucede en Eliot. En otras ocasiones en que esa heterogeneidad no existe, la confusión proviene de las vacilaciones en la conexión entre el autor y la materia literaturizada, al no establecerse con exactitud la condición experiencial de esa materia. Pero son más abundantes los casos en que la muestra culturalista se ajusta a los rasgos psíquicos del poeta, con lo que resulta de utilidad al propiciar un confesionalismo menos impúdico que ele tradicional.» op. cit. p. 182 nas pinceladas:

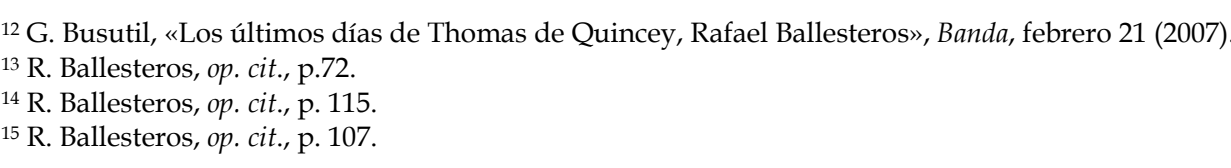


Me pareció un chico desvalido, abandonado a su suerte [...] Vi el fuego que llevaba en sus ojos. Era una mirada plana, profunda, asentada en unos ojos oscuros, grandes, que inmediatamente huyeron hacia otro lugar de la taberna; al último rincón de oscuridad.16

El capítulo más extenso e intenso corresponde a la mujer de Thomas, Margareth Simpson, hija de un granjero con la que tuvo ocho hijos. Podemos decir que en su recorrido existe mucho de novela sentimental en las relaciones que comienza con Thomas, su intento de suicidio, su permanente abandono cuidando de la plebe:

Llegaron a ser trece años, ¡trece años!, de aquí para allá, llegando a una casa, abandonando ésa para ocupar otra; aquí, la familia sola y allí, de inquilina con otra familia; vivimos en el campo, en pequeños suburbios, en las afueras de ciudades desconocidas [...] Y éramos nosotros solos. Quiero decir: los niños y yo. ${ }^{17}$

Thomas se ausentaba largamente en Londres y Edimburgo para abrir sus posibilidades de escritor, pero también vivían en una permanente zozobra por tener que hacer frente a las múltiples deudas y al agobio de los acreedores: «Y los acreedores... Dios, los acreedores, ¡Cómo sufría Thomas! Cómo lo humillaban, cómo lo avergonzaban; lo perseguían, le iban minando la salud».18

Finalmente el opio, al que necesitaba imperiosamente. Todo el proceso de la enfermedad y la adicción lo describe Margareth con fortaleza e interés para el lector cuyas páginas en este momento ofrecen una gran intensidad a partir del momento en que le increpa para que lo asfixie y así poder perder la vida definitivamente:

- ¿Qué me pides, Thomas? ¿Me pides que te mate, que te asfixie?

- No, te pido que me liberes del sufrimiento más terrible Yo no puedo, no puedo resistir... es imposible resistirlo. Tienes que tener valor. ${ }^{19}$

Es, sin duda, el apartado más conseguido, el más literario, el más intenso y e más penetrante.

$$
\begin{aligned}
& { }^{16} \text { R. Ballesteros, op. cit., p. } 110 . \\
& { }^{17} \text { R. Ballesteros, op. cit., p. } 156 . \\
& { }^{18} \text { R. Ballesteros, op. cit., p. } 157 . \\
& { }^{19} \text { R. Ballesteros, op. cit., p. } 170 .
\end{aligned}
$$

\author{
Estar los dos juntos sería suficiente. \\ ¿huida? Las cosas se rescatan. Sufren. \\ La superficie no es negación de la mano. \\ El árbol de oro es azul. Sin embargo \\ el devenir es lo que importa. Guard \\ esto entre los pliegues de tu capa. \\ Acepta. La belleza es sólo un instante. \\ ¿Recuerdas?

\section{El pino endulza tu cuerpo} \\ El iris blanco te embellece. ${ }^{27}$
}

El goce existencial se une a la contemplación de la belleza del entorno y a la remembranza del pasado glorioso. La perspectiva del yo-poético, podríamos afirmar, se sale del texto para buscar en la otredad el disfrute del momento eternizante que se fija en el poema. ${ }^{28}$ No es el caso de la poesía riquiana de Juegos del Mediterráneo, en la que la subjetividad, el sentimentalismo - al estilo de "Sepulcro en Tarquinia" de Antonio Colinas, como ejemplo también emblemático-, son anulados casi completamente.

Se confirma nuevamente que la poesía de Carlos de la Rica, en especial la de su etapa final, comparte elementos temáticos con la poesía culturalista, pero se distancia de la misma en cuanto al subjetivismo y a la función emotiva del yopoético. El resultado es el de un tipo de poesía menos hedonista y emotiva, aunque de índole culturalista. Un tipo de poesía de cariz épico-lírico, alejada de los presupuestos estéticos de los novísimos y de otros poetas culturalistas de los setenta y ochenta. La poesía riquiana hace propios ciertos rasgos culturalistas, tradicionales en

\footnotetext{
27 Op. cit. p. 129

Como señala Juan Cano Ballesta, (...) Luis Antonio de Villena busca su utopía paradisíaca en la literatura, que casi siempre es griega, romana, helenística, árabe, medieval o renacentista. All encuentra un paraíso sensorial y pagano de armoniosos cuerpos jóvenes y bellos efebos, evocado de la mano de algún poeta clásico o árabe, en un ambiente bucólico o urbano, bañado por el esplendor de la luz generalmente mediterránea." En Las estrategias de la imaginación. Utopías literarias y retórica política bajo el franquismo, op. cit., pp. 151-2.
}

LECTURA Y SIGNO, 4 (2009), pp. 223-238 
Más allá de la recreación de espacios míticos, de la admiración por la belleza del arte y de la arquitectura, del hombre antiguo, del Humanismo, el léxico es el centro formal y estructural del texto. La auténtica belleza resalta en la eufonía y la riqueza léxica, que por sí misma genera imágenes de plasticidad considerable. Pero Villena se diferencia radicalmente en la fruición de su concepto de bizantinismo. El propio autor de Hímnica y El viaje a Bizancio define su bizantinismo de forma muy plástica, acorde a los planteamientos estéticos de su poesía:

A esa Bizancio apela el título de este libro. En mito, homenaje, amor y realidad de juventud. Extasis en el texto. Edad sagrada. [...] Además, y como todo texto, Bizancio es el cuerpo de un placer. Quiere ser el insustituible laberinto de sí mismo. El autor se anula, y el receptor reina. Connotación, delfines que arrastran. Y el fulgor al fondo - el mitodonde los adolescentes viven su pasión eterna. Lo bello y condenado. Unos ojos. Un cuerpo. ${ }^{26}$

El motivo del instante es lo que señala una frontera estética infranqueable entre la poesía culturalista y la poesía riquiana de "Opera Tertia". La noción de que podemos recuperar el pasado o reconocernos en el presente a través de una reescrituración de la poesía, es compartida. Hay una necesidad de re-encontrarse en un pasado en cierta manera utópico, del que puede ser rescatada una parte, la que enlaza el poema con la realidad.

Sin embargo, como ocurría al contrastar la poesía de José María Álvarez con "Roma", en "Oda a Bizancio" de Carlos de la Rica, la fruición del instante, el goce a través del cual el yo-poético puede sumirse en otras realidades anheladas, apenas existe. Para la poesía de Villena es fundamental, el instante es uno de los elementos generadores de su poesía. En "Páginas de un pujante deseo", de El viaje a Bizancio, leemos:

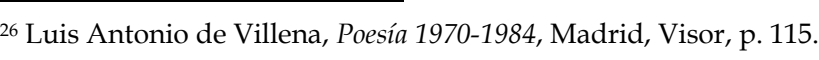

En el último capítulo es el propio Thomas de Quincey el que toma las riendas del relato $\mathrm{y}$, con el mismo comienzo in media res del resto de la obra, comienza hablando de su amigo Truchk y, acto seguido, lleva a cabo un ataque fehaciente contra los profesores que no supieron inculcarle los valores de las culturas griegas y latinas.

Pronto observamos su espíritu lírico a medida que se va adentrando en ese aire bucólico que llega de su amor a los lagos y a los días soleados, pero también la necesidad de conservar el optimismo, a pesar de la concepción del perdedor de la que está imbuido: «Perder es la base de la vida. Perder los hijos, los amores, la alegría, el placer». ${ }^{20}$

Su encuentro con Wordsworth ocupa algunas páginas. Cuando lo conoció tendría cuarenta años y nos habla de la gran influencia que ejerció sobre él y cómo se emociona el maestro cuando le lee sus composiciones poéticas. También nos habla de Coleridge y su afición al opio, su mirar impetuoso, su misterio, su carácter avasallador. Admira Quincey la belleza del orden y la trascendencia de la filosofía que él amó.

Va formando pequeñas parcelas de la memoria, breves, concisas, raudas, y va conformando una visión. Es como si a Ballesteros le hubiera importado mucho organizar su mundo en torno a fragmentos de la memoria limitándose ex profeso y evitando los excesos tanto verbales como las reiteraciones innecesarias. Esta urbanidad en la expresión puede ofrecer la sensación de orden y perfección pero también un exceso de autoridad sobre el relato, como si todo estuviera demasiado organizado y estructurado, demasiado atado de pies y manos, y no se pudiera escapar un momento la narración de sí misma proyectándose a su albur. Sin embargo, hay todo un espíritu lírico que subyace en la historia, en su escritura, y actúa casi como corriente interna, una simbiosis entre la tragedia y la poesía que

${ }^{20}$ R. Ballesteros, op. cit., p. 191.

LECTURA Y SIGNO, 4 (2009), pp. 213-222 
organizan un mundo con un elevado valor simbólico con el que Ballesteros ha querido proyectar esta lírica vida al margen de cualquier convención. Al respecto decía Garrido Moraga:

No es una prosa lírica, no es una novela poética, ni por la intención, ni por el estilo, pero la sensibilidad en forma de lirismo, de humana y cálida visión de las cosas es una constante en estas páginas. ${ }^{21}$

Para concluir, Quincey nos ofrece su análisis psicológico, su visión de sí mismo y la atracción que tuvo para él el opio, su batalla para vencerlo y la constante sensación de felicidad a pesar de todos los percances que tuvo que soportar a lo largo de su existencia. Como dirá Moreno Ayora:

Lo cierto es que la dignidad y el sufrimiento son las dos notas comunes a las experiencia de todos los personajes. De Quincey, en su particular visión de sí mismo, confirma, pues, todas las aproximaciones biográficas que de él se han ido haciendo en los capítulo precedentes, y acaba dando una impresionante lección vital al resumir su existencia como una lucha «para hacer frente al fracaso, la adversidad, la desdicha y los infortunios».22

Ballesteros es un escritor que sabe imbuirse del tipo de novela que en cada momento está desarrollando, sabe controlar los tiempos, los espacios y los procesos. Y esta organización tan estructurada, si bien nos aporta una visión pedagógica, puede evitar los arranques de la incontinencia que puede poseer la literatura. Estamos en presencia de una obra sólida que bien puede ser la resultante de una visión del mundo, aunque es verdad que más que organizar y dirimir la existencia del escritor, en realidad observamos en mayor medida su entorno y los que vivieron con él, también una época de la historia de Inglaterra, una forma de vida, de ser y de estar en el mundo.

\footnotetext{
${ }^{21}$ A. Garrido Moraga, op. cit.

${ }^{22}$ A. Moreno Ayora, op. cit.
}

Lejos de cualquier tipo de arqueologismo fatuo, el poema recala en la estética de lo bello, en la perfección de las formas artísticas bizantinas.

En cuanto a la técnica de construcción léxica del poema, que en "Roma" era ya fundamental, en "Oda a Bizancio" se repite y aumenta. El léxico es el recurso principal del poema, sin necesidad de generar apenas imágenes. Dos campos semánticos se superponen y hacen gravitar las descripciones y las alusiones: el campo semántico pagano y el cristiano. Forman un hábeas sincrético que da forma a la reconstrucción poetizada del pasado bizantino.

Y, de igual forma que en "Roma", la «visibilidad» del yo-poético se ha reducido al máximo, es apenas perceptible en el texto. Las emociones subyacen a las descripciones altamente plásticas y certeras del pasado heredado y que el poeta extrae, como un palimpsesto, de las piedras, los libros y los paisajes. En esto coincide Carlos de la Rica con la estética de los novísimos y del culturalismo de los años setenta y ochenta. ${ }^{24}$ Sin embargo, la fruición del instante como motor del poema no existe en “Oda a Bizancio". La propia ciudad, su imperio, son símbolo suficiente para Carlos de la Rica. Símbolo ideal de la reconstrucción de un pasado glorioso, que, desaparecido, destruido, se reconstruye en la realidad del poema, como en la realidad histórica.

Es obligado mencionar El viaje a Bizancio de Luis Antonio de Villena, poemario compuesto entre 1972 y $1974 .{ }^{25}$ El título remite, a su vez, a la poesía de Yeats, en concreto a Navegando hacia Bizancio, poema extenso de título homónimo a otro que Villena concibe en El viaje. Tanto en la "Oda a Bizancio" de Carlos de la Rica, como en la mayor parte de textos de El viaje a Bizancio de Villena, el fragor del lenguaje es una de las claves esenciales del poema.

\footnotetext{
${ }^{24}$ En palabras de Guillermo Carnero, una de las claves de la "nueva poesía" es "la renuncia a la expresión directa del yo confesional y sentimental" en Revista de Occidente, 23 (1983), p. 50. ${ }_{25}$ Luis Antonio de Villena. El viaje a Bizancio, Málaga, Edición Diputación Provincial, 1978.
} 
Media cristiana, la convierten en un símbolo para cualquier humanista. ${ }^{22}$ Constantino, Teodosio o Justiniano devienen personajes casi mitológicos, radicados en la Historia pero elevados en el poema a la esfera del mito bizantinista.

Pero “Oda a Bizancio" simboliza uno de los elementos generativos del ideario estético riquiano, el del sincretismo espiritual y artístico que supuso el Cristianismo para la cultura antigua. No es un tema más, una singladura más en un viaje sentimental. El yo-poético de "Oda a Bizancio" parece asentarse en un espaciotiempo histórico de auto-reconocimiento pero, sobre todo, de recuerdo. Es una perspectiva mucho más acentuada que la que encontramos en "Roma", aunque en una línea similar de identificación entre la materia poetizada y el yo-poemático. Toda la obra riquiana, al margen de cambios estéticos, se asienta, como una impronta, sobre la noción de sincretismo que, de hecho, el Cristianismo conlleva, en especial en la orientación católica. Por ello, el símbolo de Bizancio es perfecto para cerrar un periplo mediterráneo, que incluya la cultura clásica y la tradición cristiana:

$$
\begin{aligned}
& \text { Los sagrados Concilios, a Teodora } \\
& \text {-consultado el aguador hereje -. Espumas; el mágico }
\end{aligned}
$$$$
\text { talismán llamado con razón Bizancio (Constantinopla, }
$$$$
\text { como más tarde los turcos }
$$$$
\text { le dijeran Istambul). }
$$

Saber y gloria rozando tan próximo los alcanzados dedos del sacro, múltiple

$$
\text { Mediterráneo. }^{23}
$$

La métrica y la sintaxis de "Oda a Bizancio" - también las de "Oda a Barcelona" - son diferentes a las empleadas en "Roma", como parece lógico por la diferencia del momento de escritura entre uno y otro poema. Reencontramos, al estilo de la mayoría de textos de Juegos del Mediterráneo, una sintaxis organizada a base de encabalgamientos e hipérbatos, que recuerdan a la poesía barroca. El tono, como en "Roma", es elevado y se adecua perfectamente al objetivo estético riquiano.

22 En varias ocasiones, Carlos de la Rica me confesó su admiración por el arte bizantino. En cuanto al poema me lo dio a leer en 1996, manifestándome su identificación absoluta con el tema y la factura del

${ }^{23}$ Op. cit., 177 .

\section{"ROMA" Y “ODA A BIZANCIO". HUMANISMO CULTURALISTA EN JUEGOS} DEL MEDITERRÁNEO DE CARLOS DE LA RICA*

\section{JuAn CARLOS MERChán RUIZ}

IES Mercé Rodored

Juegos del Mediterráneo ${ }^{1}$ da título al conjunto poético póstumo de Carlos de la Rica. Éste, fallecido en 1997, no lo vería publicado por voluntad manifiesta, ya que había decidido pulir sus textos a lo largo de un buen número de años. Simbolizando en sí mismo al poeta humanista, prefirió dar a la imprenta ciertos textos, otros mantenerlos en los círculos reducidos de sus allegados y amigos.

\footnotetext{
Recibido: 27-02-2009 Aceptado: 02-04-2009

${ }^{1}$ Juegos del Mediterráneo, Madrid, Huerga y Fierro editores, 2001
}

LECTURA Y SIGNO, 4 (2009), pp. 223-238 
De este modo, De la Rica fusionaba vida y obra hasta el final de sus días. El título, sin embargo, forma parte de un proyecto antiguo, al que se fueron adhiriendo los poemas a medida que nacían. Un título, el de Juegos del Mediterráneo, que armoniza con una de las constantes temáticas de la poesía riquiana, la del mundo clásico. Hemos de aceptar para estos Juegos riquianos no la etimología de pasatiempo o broma, la de jocus, sino la de ludus, que designa a las celebraciones grecolatinas en honor a un dios.

Carlos de la Rica, erudito de la cultura clásica, ha buscado un título significativo para unos textos que ha ido madurando a lo largo de años y en los que ha volcado buena parte de sus motivaciones más personales y originales. Desde mucho antes de su fallecimiento, el poeta estuvo conformando sus personales ludos a Mediterráneo. Éstos están concebidos como un homenaje poético a los lugares emblemáticos de un periplo mediterráneo, el suyo, que pasa tanto por la experiencia como por el arte o la literatura.

Años de lecturas y de viajes fueron generando un itinerario que los poemas recrean, desde el Mediterráneo más próximo al autor hasta los confines del mismo. Es, justamente, el mencionado periplo el que estructura la obra. Ésta posee una unidad externa innegable, organizada en actos, pero vertebrada internamente por la singladura eterna que van aportando los diferentes poemas al conjunto. De hecho, es esta última, la interna, la que, más allá de la organización casi arquitectónica del poemario, otorga el verdadero sentido unitario al conjunto. De este modo se explica que textos escritos en fechas dispares puedan reunirse en Juegos del Mediterráneo a modo de invocación estética. El tema fundamental de todos los textos poéticos es su pertenencia al acervo creativo del autor, quien ha hallado inspiración en las fuentes mediterráneas, ya sean éstas vitales o estéticas.

Cuando Carlos de la Rica inicia su trayectoria poética y literaria, en el contexto castellano-manchego de los años cincuenta, su formación humanística - y cristiana -
La base constructiva del poema se aleja de la anécdota culturalista y permite a la voz poética adentrarse libremente en el imaginario cultural propio del mito. De esta forma se explica la forma épico-lírica adoptada por Carlos de la Rica en "Opera Tertia". Aunque la estética de Juegos del Mediterráneo elude por sistema el uso de cualquier máscara de índole culturalista, sobre el mito clásico se asientan las diversas construcciones poéticas, remitiendo al lector a un mundo acrisolado de alusiones artístico-literarias. Y aunque la experiencia vital del yo-poético sobrevuela las imágenes de los textos, la originalidad creativa de éstos reside en la inclusión del mencionado mundo de alusiones en un proceso que, a modo de palimpsesto, rescribe todo el corpus heredado.

Es un tipo de culturalismo que se aleja de cualquier canon y ensaya su propio cauce. Este culturalismo riquiano es de filiación radicalmente humanista y, apoyado en la técnica de la re-escritura y de la indagación léxica y sintáctica, persigue la recreación de un universo mítico tradicional.

Si en "Roma" los referentes literarios, como la Eneida de Virgilio, esmaltaban las imágenes alusivas, en "Oda a Bizancio" lo hacen la Historia o el Arte. ${ }^{20}$ Pero también el cristianismo, como fenómeno histórico y artístico-cultural aunque teológico, se revela como otra fuente de motivos que estructura el poema:

$$
\begin{aligned}
& \text { De modo que la liturgia solemniza los inciensos, } \\
& \text { Casullas y los sagrados mantos, } \\
& \text { Ejerciendo su oficio el pastoreo de prelados y patriarcas, } \\
& \text { Las dalmáticas de jóvenes diáconos... }
\end{aligned}
$$$$
\text { Purificados todos en las sacudidas aguas de la mar. }{ }^{21}
$$

La evolución de las formas artísticas y culturales en general que supuso Bizancio durante siglos, desde sus remotos orígenes griegos hasta el final de la Edad

${ }^{20}$ No obstante, en la estrofa sexta del poema, Eneas vuelve a ser mencionado: “(...) la cauda de los mares y el ponto que, al parecer, / vástago también del humano Anquises, / de Troya huyendo entre llamas / y las crueles antorchas." Op. cit., p. 177.

${ }^{21}$ Op. cit., p. 175. 
verdadera identificación en la dramatización del decorado histórico. Una muestra emblemática de la citada identificación entre el yo-poético y la realidad histórica poetizada la hallamos en un poema de Antonio Colinas como «Giacomo Casanova acepta el cargo de bibliotecario que le ofrece, en Bohemia, el conde de Waldstein».

De nuevo, las ciudades y los paisajes europeos se hacen eco en los versos, en e seno de una recreación histórica de gran calado estético: «Fui abad entre los muros de Roma y era hermoso / ser soldado en las noches ardientes de Corfú. / A veces he sonado un poco el violín / y vos sabéis, Señor, como trema Venecia / con la música y arden las islas y las cúpulas.»17 También en Juegos del Mediterráneo el mito clásico mediterráneo es el gran referente, ${ }^{18}$ en el que se armonizan el imaginario cultural y la noción de viaje.

Pero la génesis creativa riquiana no se conforma con una brillante y evocadora recreación del pasado. En los textos de "Opera Tertia" el yo-poético anhela el autoreconocimiento en el seno de la palabra poética. Y, mediante tal auto-reconocerse, se produce la recreación de los lugares, del mito. La técnica aprehendida del postismo consistente en construir y deconstruir la lógica del discurso poético por medio de la experimentación léxica y sintáctica, permanecen en la etapa de madurez de Carlos de la Rica, como demuestran estos poemas. ${ }^{19}$

\footnotetext{
17 Vid. Juan José Lanz. Antología de la poesía española 1960-1975, Madrid, Austral, 1997, p. 414.

${ }^{8}$ La vocación mítica de la poesía riquiana no es nueva. Proviene de los primeros conjuntos poéticos - El Mar, La Casa-, continúa con Edipo el rey, principalmente, y, ya a partir de la década de lo ochenta en adelante se potenciará en Columnario de Cuenca y Oficio de alquimista.

La concepción poética riquiana está más próxima de los presupuestos expresados por Diego Jesú Jiménez que del culturalismo. Así el mensaje estético de los siguientes versos de Jiménez -Bajorrelieve (1990) - se aproximan, en su profundidad y originalidad, a los de Carlos de la Rica. Se establece una especie de puente espiritual y estético: "Destruir y crear. He aquí dos palabras, dos bellos gestos que / nos producen placer. ¿No surge el arte / de las más dolorosas y turbias experiencias / de la razón? Construir un paisaje / con las ruinas de otro, y con la sombra de un vocablo / iluminar la vida. / He atravesado así / el santuario en el que las palabras son destino / y origen, tiempo sobre el que razas primitivas / transcribieron su historia. Signos, trazos helados, cuyo llanto es / eterno." De Diego Jesús Jiménez. Iluminación de los sentidos. (Antología). Madrid, Hiperión, 2001, 169-170.
}

da a su obra una impronta estética universalista. Y para un verdadero humanista, el Mediterráneo es una fuente inagotable de referencias históricas, culturales, poéticas en definitiva, con las que De la Rica ha ido dando forma definitiva a sus Juegos. Diferentes tiempos, diferentes formas pero un mismo tema, esta es una de las claves fundamentales en la elaboración peculiar del poemario riquiano póstumo.

En la última sección de Juegos del Mediterráneo, titulada "Ópera Tertia", hallamos el mejor ejemplo de sincronía poética basada en la unidad temática. Quizá por ser la última sección del poemario y, en puridad, también la última de una larga trayectoria, original y coherente en sus motivaciones internas, estos tres últimos poemas poseen una dimensión más profunda, definitoria de su autor. "Ópera Tertia" la forman tres poemas extensos: "Roma", "La Gloria de Bizancio" y “Oda a Barcelona".

Los tres textos son símbolos de la gran significación que tiene la tradición grecolatina y el mediterráneo en general en la poesía de Carlos de la Rica. Como en la mayoría de poemas de Juegos del mediterráneo, estos tres, especialmente, representan una de las muestras más coherentes con la voluntad que el título propone. De ese hilo conductor que sugiere una iniciación artística y vital tras los pasos del poeta.

Queda lejos de la estética heterodoxa de estos textos el culturalismo de los novísimos, al que podríamos denominar oficial. ${ }^{2}$ El que alentó con vigor a partir de la década de los setenta, y aunque la estética riquiana participe del mismo interés por la arquitectura clásica, el arte antiguo en general, las letras o el paisaje, hay rasgos divergentes muy manifiestos. Posee un cariz más profundo, que aletea en la obra riquiana desde su inicio y que supone una aprehensión de lo clásico en su espíritu prístino. No se buscan ni la añoranza cultivada ni la mera ensoñación ni tampoco la evasión más refinada. ${ }^{3}$

${ }^{2}$ Cfr. Ma del Pilar Palomo, La poesía en el siglo XX (desde 1939), Madrid, Taurus, 1988, pp. 159-160. ${ }^{3}$ Seguimos a Juan Cano Ballesta cuando trata de la poesía española culturalista: "Varios lustros de una poesía rica en soluciones individuales, pero cuya tendencia más aclamada se orientaba hacia lo 
Los poemas finales de Juegos del Mediterráneo pueden permitirse un desfase notorio en las fechas de escritura, porque el conjunto está en conexión atemporal con los criterios estéticos internos de la obra riquiana.

El pasado siempre es presente en estos textos, y no se persigue con ellos evocar realidades sugerentes en última instancia, sino como se asienta el verso en el espíritu - también la forma - clásico. No sucede el éxtasis estético tras la lectura, se trata de una identificación entre el yo-poético y la realidad poetizada. Esta manifestación estética prescinde del estado transitorio del poeta, de su estado de ánimo, sumido en la captación del instante o del ambiente, o del imaginario cultural incorporado al texto de forma más o menos directa.

En los poemas de "Ópera Tertia", la experiencia del poeta se diluye en la figuración de las ciudades mediterráneas que han dado pie a los textos. Son ellas exclusivamente el centro de atención temático, por encima de cualquier otro motivo circunstancial o tangencial, por pertinente que pueda llegar a ser. El botín del Mundo de José María Álvarez, ${ }^{4}$ en su brillantez culturalista, es un conjunto poético que posee ciertas premisas estructurales no muy alejadas de Juegos del Mediterráneo de Carlos de la Rica.

Sin embargo, la estética de la que emerge la poesía de Álvarez contrasta con la riquiana y, en ese contraste, se vislumbra el aporte de originalidad de ésta. El botín del Mundo se asienta en una estructura similar a la de Juegos, puesto que en ambos poemarios el viaje es el eje temático vertebrador. Los textos reviven un itinerario estético a la par que vital, ajustándose al metaforismo del título. De cada rincón

testimonial, el realismo documental, la protesta y la lucha política, habían hundido el lenguaje poético en el prosaísmo de lo banal y cotidiano. [...] Los novísimos (en torno a los años 1966-1980) vuelven la espalda a la realidad social del entorno para consagrarse a la imaginación evocativa, que en este caso les conduce a explorar utópicos mundos de gran belleza. [...] La huida de la realidad conduce cas inexorablemente hacia los reinos de la fantasía y el sueño, lleva a la búsqueda de ambientes apetecibles y de utopías, que dados sus intereses y gustos suelen tener carácter estético." Vid. Juan Cano Ballesta, Las estrategias de la imaginación. Utopías literarias y retórica política bajo el franquismo, Madrid, Siglo XXI, 1994, p. 148

${ }^{4}$ José María Álvarez, El botín del Mundo, Sevilla, Renacimiento, 1994.
Mediterráneo, no se nos hace partícipes de una mera emoción hallada en el camino. Por el contrario, el yo-poemático recrea una búsqueda, la de sí mismo, en el destino que simboliza cada uno de los textos. Es en la estrofa final donde el yo-poemático declara abiertamente el sentido del viaje y, por tanto, el del texto en sí: «Vuelvo, puedo, pongo lábaro, / friso y remo / por seguir, oh Roma, en tu casulla.» ${ }^{16}$

La concepción de la creación poética que se constata en los textos de Juegos del Mediterráneo de Carlos de la Rica, antepone la propia palabra poética a cualquier tipo de emoción inmediata, incluso de índole sentimental. La palabra en sí se desvela como el objetivo fundamental del poema. Las vivencias del yo-poético quedan, si no relegadas, sí supeditadas al máximo a la evocación generada por las palabras. Éstas se estructuran alrededor de una sintaxis barroca, que aleja del texto si cabe aún más del protagonismo del sentimiento fugaz del instante, más propia de estéticas ya mencionadas anteriormente.

La noción de poema que emana de "Roma", y del resto de textos de "Opera Tertia", es la de contener una determinada función reveladora, asentada en la tradición clásica y también en la tradición posterior. La poesía de Juegos del Mediterráneo revela aquello que permanece de la Naturaleza y, sobre todo, de la Historia. El poeta emerge del esplendor del pasado común mediterráneo, fuente primordial de la temática general del conjunto. La idea de poeta y de poesía que surge de "Opera Tertia" se halla lejos de los presupuestos estéticos del culturalismo, a pesar de que comparte, superficialmente, cierto tono y, sobre todo, la inspiración de algunos temas.

Lo efímero se acepta en el poema si forma parte del conjunto, nunca como motivo configurador o como objetivo estético final del mismo. No existe una

una realización espiritual exige del hombre el que se despoje de su yo corriente y habitual a fin de volverse verdaderamente «sí mismo», transformación que va acompañada del sacrificio de aparentes riquezas y vanas pretensiones, es decir, de humillación y del combate de las pasiones de que está tejido el «viejo yo»." De Símbolos, J. Olañeta Editor, Barcelona, 1997, p. 34. ${ }^{16}$ Op. Cit., p. 172 
Si comparamos el final de "Budapest" - «Ya todo es mundo. Oh sentidos, desvaneceos / en esta plenitud.» - con el final de "Roma" de Carlos de la Rica, se observa la radical diferencia de planteamiento estético, aunque en ambos textos el componente cultural sea determinante. $\mathrm{El}$ «YO» manifiesto de "Roma" no ansía una desintegración o disolución de su condición, porque se auto-reconoce en el arte, la arquitectura, la historia o la poesía del entorno romano: «Pude volver y vuelvo, Roma / loba o diosa, a tus colinas; / pude volver, llegué. Virgilio / si animal de Frigia o Troya.»13

Es un yo-poemático amparado por la variada y larga tradición, que los versos van recorriendo a lo largo del texto. Pero un yo-poemático que, a diferencia del de los textos de los novísimos, se vuelve a veces imperceptible. Se trata, en todo caso, de una poesía donde predomina el yo implícito. ${ }^{14}$ En "Roma", se da una correlación objetiva entre la recreación del tema romano y la emotividad del yo-poemático. Alternan las paraestrofas en las que el sujeto de la acción es la primera persona y en las que se desplaza a una segunda o tercera persona. Se persigue con ello, ante todo, la analogía espiritual entre el poeta y el motivo de inspiración, sin que se hagan demasiado explícitos ni el sentimentalismo ni la emotividad.

El Mediterráneo es el destino del viajero y las ciudades de "Opera Tertia”, por extensión, son su materialización. Tras los muros milenarios de Roma, el yo-poético evoca un pasado mediterráneo compartido, en el que se reconoce a sí mismo. Una vez despojado de las sensaciones efímeras, el poema emula a las piedras o al mar y se construye como una evidencia de supervivencia de la Historia. En ella, el poeta reencuentra, como Ulises o como Eneas, Pedro o Pablo, el origen, el destino al que se arriba después del periplo. ${ }^{15}$ En la mayor parte de los poemas de Juegos del ${ }^{13}$ Op. cit., p. 172.

${ }^{4}$ Vid. Ángel L. Prieto de Paula, Musa del 68. Claves de una generación poética, Madrid, Hiperión, 1996. Respecto al análisis del yo-poemático, es especialmente útil el capítulo final «Poeta y sujeto poemático», pp. 329-368.

${ }^{5}$ La imagen que el poemario construye del yo-poético es la de un viajero, en la que se materializa, de alguna forma, el mito del regreso de Ulises. Como señala Titus Burckhardt: “Toda vía que conduce a visitado se extrae una reflexión o una emoción, una identificación, en definitiva, entre el poeta y la aprehensión de lo circundante.

Como en Juegos del Mediterráneo, en El botín del Mundo hay ciudades - algunas también mediterráneas-, que motivan poemas a causa de las reminiscencias históricas, artísticas o literarias. Los títulos de los poemas son, per se, significativos: "El embrujo de Shanghai","Fiesta en Venezia, citta nobillisima et singolare" ,"Estampa de Murcia“, "Budapest", “Homenaje en Petrópolis“. En sí, ni el yo-poético cautivado por el arte o la belleza ni los homenajes a escritores son conceptos poéticos ajenos a la poesía riquiana.

En poemarios anteriores a Juegos, como en Columnario de Cuenca y, sobre todo, en Oficio de alquimista, el homenaje poético es una estructura que se reitera y que supone una de las características fundamentales de la poesía de Carlos de la Rica en la década de los noventa. Entre la gran variedad de poetas culturalistas, nos hemos centrado, por similitudes temáticas e importancia, en El botín del Mundo de José María Álvarez. ${ }^{5}$ En los textos de El botín y similares, el yo-poético es el factor principal en la perspectiva del texto, más allá incluso de la materia poetizada. El motivo de inspiración media entre el yo-poemático y la realidad poetizada en sí misma. De forma diferente, este proceso se subvierte en los textos de Juegos del Mediterráneo, donde el yo-poético se difumina, resultando integrado en el lenguaje mismo. ${ }^{6}$

De la Rica persigue alcanzar un estadio intelectualizado de la vivencia, superar el goce del instante inestable y promover el pasado en su visión presente, como una especie de herencia humanista inmarcesible. Si, por ejemplo, comparamos "Homenaje en Petrópolis" de José María Álvarez con cualquiera de los textos de

${ }^{5}$ Vid. Luis Bagué Quílez, «La recuperación del sentido clásico en la última poesía española», Hesperia. Anuario de Filoología Hispánica, VI (2003), para la aquilatación de las diferentes directrices estéticas de la poesía culturalista.

${ }^{6}$ Como afirma Antonio García Berrio: «La imaginación cultural, en el fondo, no es sin embargo ajena a la confidencia conflictiva o gozosa del yo que alimenta directamente la imagen de la inspiración antropológica; pero lo es indirectamente, por vía mediada.» En Teoría de la literatura (La construcción del significado poético), Madrid, Cátedra, 1994, p. 479. 
"Ópera Tertia", advertiremos cómo la motivación culturalista es distinta de la del yopoeta-humanista de De la Rica. O, en todo caso, el culturalismo de los textos riquianos se situaría en una búsqueda del despojamiento emotivo. ${ }^{7}$

El poema culturalista recrea un monólogo imaginario, espiritual, del poeta, dirigido hacia Stefan Zweig. Álvarez ha proyectado su evocación hacia un momento simbólico de la Historia y de la literatura occidentales del siglo XX, el suicidio del matrimonio austriaco, perseguido por Hitler, del que hay una famosa fotografía, tomada en 1942 en la ciudad brasileña de Petrópolis. El poema evoca la instantánea y se produce un monólogo, una dramatización, en la que el yo-poético pretende hacerse oír:

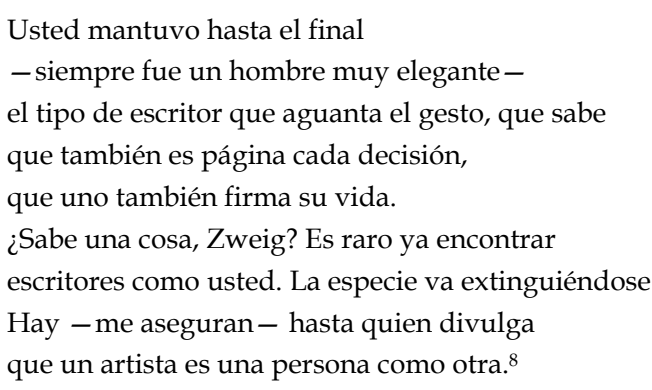

La poesía riquiana, en cambio, dialoga básicamente consigo misma. De ahí e empleo de uno de sus recursos estilísticos más genuinos, el de la interrogación retórica. El monólogo se dramatiza, por tanto, y a diferencia del que hallamos en "Homenaje en Petrópolis", ${ }^{9}$ internamente, sin perspectivas externas a las del propio texto. En el primero de los tres poemas, incluidos en la última sección de Juegos del

Luis Bagué define una de las trayectorias estéticas en el seno de la poesía culturalista: «La asunción de la lírica grecolatina conlleva también un importante progreso en la superación del culturalismo $d e$ cita externa propio de los "novísimos". En éstos, el acercamiento al mundo clásico se articulaba sobre un doble plano: la cita literaria como apoyatura referencial, o bien como homenaje culturalista. Entre los frecuentadores más asiduos de la primera faceta se hallaría José María Álvarez. [...] Al homenaje culturalista se adscriben, en cambio, aquellas composiciones que remiten a un sustrato específicamente neoclásico, ya sea en su acotación cronológica, en su referente temático, en su despojamiento emotivo o en su técnica lógico-discursiva.» Art. cit., pp. 28-29.

${ }^{3}$ Cf. José María Álvarez, El botín del Mundo, op. cit., p. 103.

${ }^{9}$ Op. cit., pp. 102-103.
Mediterráneo, "Roma", ${ }^{10}$ De la Rica recurre a una personificación para disponer un monólogo no de mera evocación del pasado glorioso de Roma, sino de reafirmación del presente como un todo:

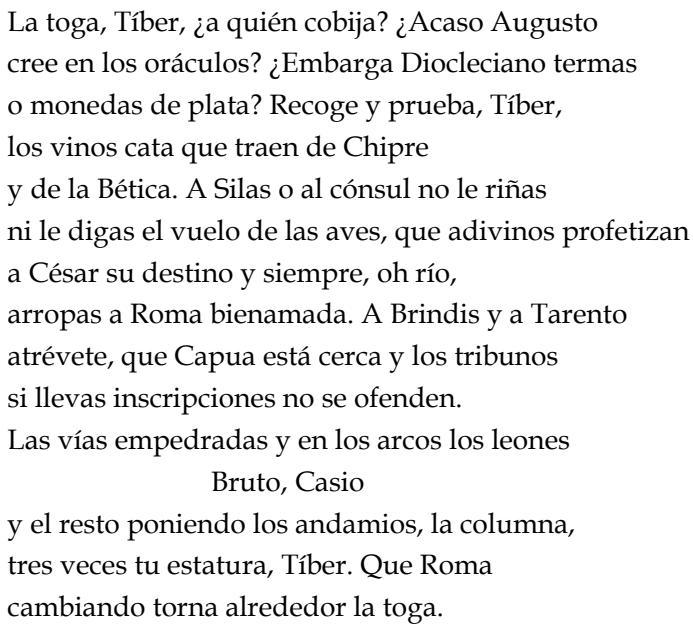

El poema halla el cauce expresivo, precisamente, en la técnica dramatizadora que aportan las aposiciones, las ya mencionadas interrogaciones retóricas o el empleo de la segunda persona verbal. Con ello, en el poema se establece un diálogo interno entre el yo-poético y la eternidad del presente, que simboliza la ciudad de Roma: «YO / junto a la terraza / añorando el velo y las cenizas / los edículos. (...) / Tal, Roma, / en mi hendidura quedas, amante más y poseída / en mi sueño.»11 En otro de los poemas de El botín del mundo, "Budapest", se reproduce una escena de contemplación extática, en la que el yo-poético se ha visto inmerso:

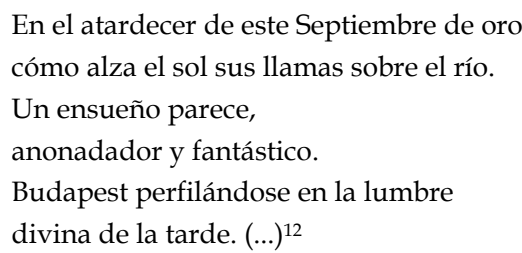

${ }^{10}$ Roma, Cuenca, El toro de barro, 1981. El proceso de escritura de este poema es muy anterior a su publicación definitiva en Juegos del Mediterráneo, en 1997. Pero forma parte sustancial del proyecto final de Juegos.

${ }^{11}$ Op. cit., p. 170

12 Op. cit., p. 52. 
la protección, el ser benefactor que no pide nunca cuentas a sus hijos de sus errores, el abrigo frente a la injusticia y a la soledad, la única que lo perdona todo con sinceridad.

En el poema «Hablo con mi madre» de Blues castellano el poeta le pide que le muestre de nuevo la tierra de la que él procede. La madre biológica y la naturaleza se funden en una clara alusión de resonancias panteístas:

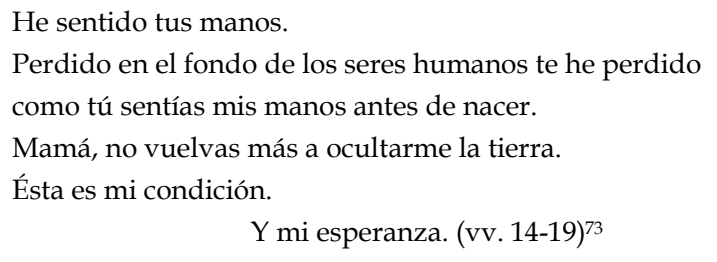

En Descripción de la mentira se alude a esa reversión del viaje interior hacia e pasado con el arquetípico término de Gamoneda, y de sus críticos, denominado «retracción». Este movimiento reversivo es el que va a vertebrar el desarrollo de la «diégesis» poética desde el principio de su obra hasta prácticamente el final: «[...] mi obra es la retracción, la retirada hacia una especie maternal». ${ }^{74}$ En la misma obra, de manera metonímica, se alude a ese génesis desde los pezones de los senos maternos. Es la época de lactancia, el alimento líquido con el que se inicia la vida tras el de la placenta. Así pues, una serie de distintas «aguas» se acaban reuniendo para regenerar al ser y llevarlo hacia una raza superior de hombres que manifiesten esa supremacía al valorar su radical igualdad en derechos y en deberes: «[...] si yo despierto y tus pezones manan sobre mi boca y no sé tu nombre y me alimentas antes de abandonarme,/ mi respuesta entra en ti y existe el tiempo como una reunión de aguas: estoy en ti y no he temido tu desaparición./ [...]/ Yo estoy naciendo en otra especie $[\ldots] \gg .{ }^{75}$

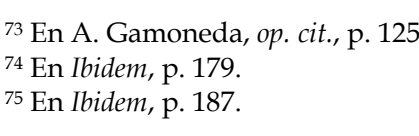

de una quimera del ser y de la palabra hacia lo primigenio. Está hecha desde tropos que en su representación ilógica de lo no contingente de la personalidad humana le acercan más a la órbita del surrealismo de un Larrea, Vallejo o Westphalen y del creacionismo de un Huidobro. Esa deuda se deja ver en la imagen onírica y en el rapto alucinatorio que también tuvieron los místicos. Así lo expresa el mismo Gamoneda: «La palabra "trascendencia” me da mucho miedo: no sé manejarla. En mi trabajo poético puede haber contaminación de lenguaje religioso, pero no convicciones. No soy hombre religioso aunque pueda estar habitado por voces religiosas».6

Con su influencia inhibe los mecanismos pretendidamente cognitivos y racionales del yo para llegar a manifestar la verdad pararracional y emocional del yo lírico. Para él, la palabra es más importante que lo referencial, mimético y representativo hacia un discurso autorreferencial, semiótico y simbólico. Debicki lo llama «poesía de descubrimiento», aquella que forja nuevas visiones desde el uso creativo de un lenguaje de a diario, de acontecimientos anecdóticos y de evocaciones personales.7 También el mismo crítico la califica de «esencialista» y sitúa su apogeo en los años 80. ${ }^{8}$ Esta poesía estaría según Silver en esa tradición dual española de «relación ambigua con la realidad»y de «curioso movimiento de atracción hacia los objetos naturales a la par que de repugnancia ante ellos». ${ }^{9}$ Es decir, el poeta parte del campo de lo real para representar de manera comprensible lo surreal. Por su parte, Fernando Castro ha denominado su obra como «[...] [c]anto del origen y de la soledad», en clara alusión a esa introspección en el mundo, en la otredad y en el yo. ${ }^{10}$

\footnotetext{
${ }^{6}$ A. Gamoneda, op. cit., p. 173

En A. Debicki, Poetry of Discovery: The Spanish Generation of 1956-1971, Lexington, Ky, The University Press of Kentucky, 1982, p. 18

${ }^{8}$ En A. Debicki, Historia de la poesía española del siglo XX: desde la modernidad hasta el presente, Madrid, Gredos, 1997, p. 259

9 En P. Silver, La casa de Anteo: Ensayos de poética hispana (De Antonio Machado a Claudio Rodríguez) Versión española de Salustiano Masó, Madrid, Taurus, 1985, p. 46.

${ }^{10}$ En F. Castro Flórez, «Manos de tierra» en AAVV, Antonio Gamoneda, Madrid, Calambur, 1993, p. 36.
}

LECTURA Y SIGNO, 4 (2009), pp. 239-271 
El ovetense, formado en León, ha negado insistentemente que su obra se inscriba dentro de las tradiciones místicas canónicas. La verdad es que él quiere advertirnos de su desvinculación de un mensaje de orden teofánico o estrictamente religioso. La mística habla de una relación individual del hombre con la divinidad y ese nunca ha sido su propósito ni en lo vital ni en lo poético. Este pensamiento no sigue las reglas de lo religioso y da libertad al examen personal de la muerte y de la posibilidad de lo trascendente. No cabe duda de que esta poesía trata de buscar esa trascendencia irreal e imposible de la que se duda con un modelo similar pero invertido hacia una exploración inmanente. Dicha inversión consiste en que vamos de la exaltación de lo divino a la de la ipseidad y a la de la creación de la vida. Además, es palmaria su simpatía hacia la izquierda, el compromiso hacia el materialismo sociohistórico (véase la admiración e influencia hacia el poeta comunista turco Nazim Hikmet) y un innegable pesimismo en el porvenir de la humanidad y, por extensión, del ser humano como ente concreto.

No obstante, ciertas problemáticas que se encuentran en su obra poética van a incidir en ciertos temas recurrentes en la denominada «poesía del silencio» de innegables tonos esotéricos. El poeta, según Mayhew, se erige en un demiurgo, transformándose «[...] from a concrete historical individual into a transcendent force». ${ }^{11} \mathrm{Su}$ obra acaba convirtiéndose en una mística revertida hacia lo profano si se evalúan ciertas ideas e imaginería que usa. Por ejemplo, la figura de Dios aparece en su obra entre la decadencia del ser y del ambiente degradado que le rodea. Esta figura es enunciada con una «d» minúscula que evidencia su agnosticismo y la creencia de que no hay una divinidad que nos una a todos, sino sólo los dioses particulares que nos creamos a causa del miedo al sufrimiento y a la desaparición total con la muerte. De acuerdo con Manuel Vilas, la teosis en su poesía «está cargada 11 En J. Mayhew, «Rhetoric and Truth in Gamoneda», in The Poetics of Self-Consciousness. Twentieth
Century Spanish Poetry, Lewisburg, Bucknell University Press, London and Toronto, Associated University Presses, 1994, p. 89 valor de un arquetipo y nos devuelve al tiempo de los orígenes, que la poesía busca una y otra vez».71

Las resonancias cristianas tanto en la religión como en el arte son evidentes en su obra: la imagen de la pietà o del stabat mater enfrente de la cruz. La obra de Gamoneda se centra y se recrea en el dolor y por ello podemos considerarla, sobre todo desde Exentos II, como un martirologio, como una penitencia mortificatoria del yo lírico. De esta manera, se produce una purificación de este ser en su llegada al momento cúspide de la desaparición. Allí, la madre recupera y reengendra al hijo y le da nueva forma como una generación más en sus descendientes. De todas formas, recordemos que el sentido trascendente está ausente en esta obra. Es un deseo de evocar una arcadia perdida en la que la inocencia blindaba al sujeto frente a la turbamulta del mundo. El canto del origen es un deseo de olvidar la locura del mundo real, que usa a los individuos y que tan pragmática como cínicamente se hace llamar como «razón de estado», para articular un espacio maternal de resonancias telúricas. Esperanza Ortega lo pone en estos términos: «Es la voz de la tierra, la voz del origen, la voz de lo material y maternal».72

Psicológicamente hablando, es un proceso de anclaje para situar a un ser descentrado ante la angustia frente a la muerte que se siente como inminente. La neurosis de insatisfacción vital, amatoria y erótica que preside las páginas de sus poemarios es la causa de esta obsesión. Es una fobia de anticipación ante algo que se sabe que ha de llegar: el final de la vida. Por ello, el estro literario de Gamoneda se convierte en una manera de sublimar el horror ante lo perecedero, una manera de justificar la existencia y de pretender perpetuarla mediante la palabra. Asimismo, la vuelta a la madre no sólo es un ideal de resurrección, sino también algo más cercano:

\footnotetext{
${ }^{71}$ En A. López Castro, «Antonio Gamoneda: la poesía de la memoria», en Voces y memoria. Poeta leoneses del siglo XX, Valladolid, Junta de Castilla y León, 1999, p. 161.

72 En E. Ortega, «La música de la oscuridad. Antonio Gamoneda», Campo de Agramante, 5 (2005), p.
} 
Hablan los manantiales en la noche, hablan en los imanes del silencio. Siento la suavidad de las palabras olvidadas. (p. 340)66

\section{$[\ldots]$}

La mujer cuyo corazón es azul y te alimenta sin descanso,

ésa es tu madre dentro de la ira;

la mujer que no olvida y está desnuda en el silencio

ésa fue música en tus ojos.

Vértigo en la quietud: en los espejos entran sustancias corporales y arden palomas. Tú dibujas juicios y tempestades y lamentos.

Así es la luz de la vejez, asi

la aparición de las heridas blancas. (vv. 6-12)

\section{LA MADRE COMO LOCUS ORIGINARIO}

Nos dice Álvaro Valverde que su obra «es un discurso circular: va y vuelve sobre la memoria cíclicamente»68 para recuperar, depurar y reformar un origen personal y colectivo a través de la obsesiva figura de la madre y de la ausencia paterna: «Toda ella se debe a una estética de la retracción que va de lo real o exterior (despojamiento, brevedad, ajuste, intensidad, cortedad, elipsis) a lo simbólico o interior (vuelta a lo materno, a lo original, a lo primario)».69 Es un problema de identidad porque siente que no tiene «padre ni especie» (v. 1) en Exentos $I I,{ }^{70}$ ya que fue privado de esa figura cuando era un niño. Esta carencia le ha castrado emocionalmente y le ha conducido a ese deseo edípico de volver a la placenta materna representada por las aguas del mar y de la muerte. La madre, por ende, deviene en un centro desde el que se va a irradiar la vida del nuevo ser y del nuevo cosmos, y sus aguas simbolizan las de la suppa primigenia desde la que se originó la vida. Como bien dice Armando López Castro: «El símbolo de la madre asume el

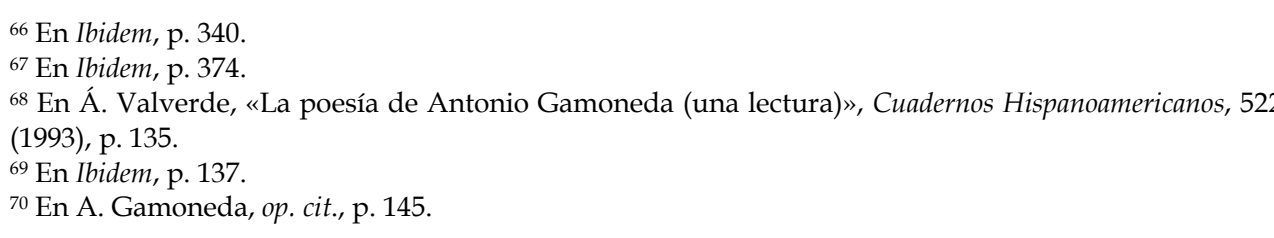

de un simbolismo negativo; es como si el dolor humano sepultase también la esperanza divina». ${ }^{12}$

Gamoneda está unido a una amplia corriente que en este siglo ha penetrado, con mayor o menor calado, en la literatura hispánica en las obras de Carlos Bousoño, Octavio Paz, José Lezama Lima, María Zambrano y Clara Janés, entre otros. Y sobre todo está vinculado a la de su amigo José Ángel Valente, la más directa. Por ejemplo, hay unas actitudes de «escepticismo», «ataraxia» y «preparación ascética» frente a una caediza realidad que le unen a Valente para Amelia Gamoneda y Fernando R. de la Flor hacia un «éxtasis final "blanco"» en el «momento en que el sujeto ha culminado su trabajo de reconstrucción de sí mismo».13 De hecho, Jorge Rodríguez Padrón lo ve como una «mística del revés: descenso [...] hasta la verdad que es mentira habitual». ${ }^{14}$ Como veremos, en el caso de este último, hay un escepticismo materialista y un sentido agnóstico en el itinerario de Gamoneda que se detiene mucho antes de que se pueda atisbar esa unión personal que se producirá en el centro de la ipseidad con la esencia de lo originario que formó lo cosmológico y al ser.

Él mismo reconoce lo siguiente en su estudio sobre Valente: «Creo que permanezco en un materialismo visionario y en un agnosticismo pasivo. Sin embargo, yo me he acercado también a la luminosidad del no ser, o mejor, la he atraído hacia mí (...)».15 Por otra parte, considera que la crítica ha situado al gallego «en un orden metafísico y hasta místico» y a él mismo en el «hermetismo e irracionalismo», algo que niega ya que lo irracional no puede generar la lógica de un

12 En M. Vilas, «La muerte, y su hermano el miedo: la "edad" de Antonio Gamoneda» en AAVV Antonio Gamoneda, Madrid, Calambur, 1993, p. 52.

${ }^{13}$ En A. Gamoneda y F. R. de la Flor (eds.), «Preliminar» en Sílabas negras, Salamanca, Ediciones Universidad de Salamanca y Patrimonio Nacional, 2006, p. 59 y nota 110.

${ }^{14}$ En J. Rodríguez Padrón, «Desnudo ante el agua inmóvil» en AAVV, Antonio Gamoneda, Madrid, Calambur, 1993, pp. 135-144, p. 140.

${ }^{15}$ En A. Gamoneda, Valente: texto y contexto. Santiago de Compostela, Universidade de Santiago de Compostela, 2007, p. 66. 
poema. ${ }^{16}$ De todos modos, ambas actitudes, desde dos ángulos opuestos, convergen en ese punto de aislamiento de la historia hacia un origen situado en lo que se puede denominar como un archipretérito o pasado ideal, arquetípico. Allí, desde el útero materno, se podría reconstituir una nueva Historia con «H» mayúscula, un nuevo ser y un nuevo logos. Es un retorno pagano hacia una naturaleza matriz que, como bien advierte Juan Carlos Mestre, representa «la pasión mística y romántica de una voluntad tan próxima a la herejía como al panteísmo».17 El uso de vocabulario que alude a lo fronterizo de los «bordes» o «límites» entre la vida y la muerte, o de animales, de plantas y de líquidos taumatúrgicos que simbolizan la descomposición de la identidad, de pájaros espirituales, de «dioses» individuales, de niños que van en busca de su madre, de olvidos, de fulgores, de vértigos, de quietudes, de transparencias y de silencios, así como alusiones a la pintura abstracta y a un paratexto de resonancias esotéricas de Lezama Lima que dice que «la luz es el primer animal visible de lo invisible» (en Material Memoria de Valente de 1977 y en la más reciente Cecilia escrita entre 2000 y 2004 por Gamoneda) son algunos de sus incontables parecidos que los entroncan.

Pero volviendo a nuestro autor, huelga decir que existen ciertas topografías literarias por las que discurre su obra. El punto de partida es un alejamiento de la historia real, fenoménica, injusta, ascética. Posteriormente, se adentra en una ultrahistoria o historia interior, psicológica, alienada, iluminativa, del ser en búsqueda de sí mismo. Y finalmente, pretende ir hacia esa nueva Historia gnoseológica, ilusoria, unitiva, que se detiene en los albores de la muerte sin apenas esperanza de eternidad. Es un viaje interior en busca del amor humano más allá de la muerte. Como nos advierte Antonio Colinas: «Toda la obra de Gamoneda es como

\section{${ }^{16} \mathrm{Ibidem}, \mathrm{p} .67$}

7 En J. C. Mestre, «Sublevación inmóvil» en AAVV, Antonio Gamoneda, Madrid, Calambur, 1993, pp $87-94$, p. 90 . iluminativo que va de una purgación personal a una unión interior que nunca se producirá completamente en su obra. Lo importante es ver la riqueza de la imaginería y de las metáforas para expresar la inefabilidad del trayecto ideológico y poético que se emprende. Gamoneda, en pocas palabras, es heredero de la amarga autorreflexividad de que hicieron gala los místicos de la Cábala, del Sufismo o del Cristianismo en la España medieval a la hora de expresar lo intangible de la percepción esotérica. Esa falta de significantes, así pues, se suple con ese nuevo lenguaje que, en contra de lo que se piensa, no es conservador (no en vano se aparta del poder) sino progresista (ya que pretende un cambio en el pensamiento, en la historia y en la realidad).

Veamos cómo formula esa palabra originaria redentora en Libro del frío:

$$
\begin{aligned}
& \text { Hay un muro delante de mis ojos. } \\
& \text { En el espesor del aire hay signos invisibles, } \\
& \text { hierba cuyos hilos entran al corazón lleno de sombra, } \\
& \text { líquenes en el residuo del amor. (vv. 1-4) })^{65}
\end{aligned}
$$

Finalmente, otro aspecto importante que conviene destacar es el papel del silencio. Es el resultado de la desarticulación del lenguaje convencional y de su expansión en los territorios de un conocimiento pararracional. Para construirlo, se busca esa palabra depurada que remite, en balde, a la primera palabra del lenguaje, la ideal de abolengo verlainiano o juanramoniano. El hecho de que el silencio represente todo aquello que los sentidos humanos no pueden percibir, esa realidad oculta que nos puede ayudar a conocer mejor la verdad, no implica que sea completamente inmaterial. Está antes o más allá de la percepción del hombre, pero en él reside toda una ciencia del destino. Tiene un poder convocador de nuevos sonidos y palabras, los del origen. En él espera la madre para introducir de nuevo al yo lírico en su seno y hacerle renacer. En la misma obra, nos lo muestra de este modo en los dos siguientes fragmentos:

${ }^{65}$ En Ibidem, p. 375.

LECTURA Y SIGNO, 4 (2009), pp. 239-271 
Véase ese valor de lo musical como revelación después de la muerte en Sublevación inmóvil:

$$
\begin{aligned}
& \text { Cantidades de tiempo } \\
& \text { sitúan cantidades } \\
& \text { de sonido. Escucho } \\
& \text { más allá de la muerte. } \\
& \text { La música se alza } \\
& \text { de un pozo de silencio; } \\
& \text { es labranza del aire } \\
& \text { en tímpanos de fuego } \\
& \text { y ha entrado en mí. Ahora es } \\
& \text { música mi pensamiento. }{ }^{62}
\end{aligned}
$$

O en este iluminador fragmento de vaciamiento interior y de llegada a la plenitud órfica en la inmaterialidad del silencio de Descripción de la mentira: «Escuché hasta que la verdad dejó de existir en el espacio y en mi espíritu,/ y no pude resistir la perfección del silencio». ${ }^{63} \mathrm{O}$, por último, en este otro extraído de Lápidas, situado en la iluminación no de la unión, sino de la muerte. Es un espejismo antes de llegar a un oasis de extinción personal: «Aquel aire entre el resplandor y la muerte se hace sustancia que no alcanzan a borrar los días y los vientos. El contenido de la edad son estos lienzos transparentes. Signos exactos e incomprensibles. Están en mí con el valor de una llaga; algunas cifras arden en mis ojos».64

Por consiguiente, en su obra la palabra se va haciendo cada vez más conceptual y el discurso entero se atomiza para intentar captar esa nueva realidad que se resiste a aparecer ya que reside en los espacios en blanco entre los poemas. A saber, es el lector el que va a ir completando ese rompecabezas conceptual con su arbitraria descodificación semiótica. Este proceso de disgregación es paralelo al de desintegración del ser frente a la gnosis. De una expresión lírica y más testimonial vamos a otra más abstracta y sintética del mismo modo en que del cuerpo se escinde la psique y finalmente se reabsorbe en esa búsqueda identitaria. Es el movimiento

$$
\begin{aligned}
& { }^{62} \text { En Ibidem, p. } 68 . \\
& { }^{63} \text { En Ibidem, p. } 173 . \\
& { }^{64} \text { En Ibidem, p. } 253 .
\end{aligned}
$$

una soterrada batalla entre la crueldad de la realidad y la ternura humana», usando el tema de España sin la retórica fácil de posguerra. ${ }^{18}$

Su obra, así pues, se propone evadirse de lo real yendo a lo que Lyotard llamaría el sublime, la expresión postmoderna de lo inefable. ${ }^{19}$ Lamentablemente, el poeta no cree que haya nada más allá del último estado del ser en el tiempo, la muerte, aunque lo desearía. La única posibilidad factible de redención es la perpetuación a través de la palabra. Esta continuidad y evolución de la vida van ligadas al intento de buscar un significante que posea la plenitud de los significados en su interior y que redima a los humanos. Él está más allá del «umbral», de los «límites» o «bordes», palabras que prefiguran la separación entre la vida y la muerte, entre el eros y el tánatos, el ordo amoris y el ordo tremoris. Es un nuevo espacio, entre lo rural depurado y lo interior, y un nuevo tiempo, el que se proyecta hacia la muerte desde un retorno a una infancia idealizada. Ambos vectores están incardinados en una premodernidad estetizada en la que el ser y el mundo todavía no se habían constituido. Desde allí se debe recomenzar la historia sin cometer los pasados errores y alcanzar una «justicia» de carácter social que una de nuevo al hombre con el mundo y con su arkhé. ${ }^{20}$ Esa es la nueva Historia ideal, una ilusión de comunión, de solidaridad, de salvación y de eternidad humanas.

Ni que decir tiene que esta llegada al momento de la generación telúrica de la vida es para él una vuelta a la madre. Ella tiene un significado dual: la biológica y la panteísta de la creación de lo cosmológico, de lo natural, de los seres y del yo lírico. Lo plasma en sus versos con un doble motivo: para dejarlos con la intención de que los recojan las siguientes generaciones y para conjurar un quimérico estado de depuración de la agonía anterior a la muerte. Ese es el de una nueva vida que se

${ }^{18}$ En A. Colinas, «Lápidas, de Antonio Gamoneda: un humanismo para el fin de siglo», Ínsula, 487 (1987), p. 17.

19 En J. F. Lyotard, The Postmodern Condition, 1979, Translated from French by Geoff Bennington and Brian Massumi, Minneapolis, University of Minnesota Press, 1993, pp. 78-81.

20 En J. C. Suñén, «La expresión de un deber desconocido (Poesía y conciencia en Blues castellano)» en AAVV, Antonio Gamoneda, Madrid, Calambur, 1993, p. 100.

LECTURA Y SIGNO, 4 (2009), pp. 239-271 
desea que se repita con más armonía y que conlleva un nuevo conocimiento que se representa a través de lo fragmentario, en cuyos intersticios parece hallarse un saber que la articulación convencional del lenguaje y del discurso se resisten a captar. A falta de un conocimiento total, ese saber se puede mostrar discursivamente sólo de manera limitada en su multiformidad. Esta poética asume la imperfección de los humanos para llegar a codificarlo, así como que lo racional es tan sólo un débil intento de manifestar lo real. Por ende, lo irracional se erige como una ampliación, no como una subversión, epistemológica del conocimiento convencional e institucionalmente aceptado. Si se apela a una nueva realidad, que está más allá de lo sensorial y que es sólo representable desde el orden simbólico y metafórico, y que los hombres son imperfectos para alcanzar el conocimiento pleno, con razón se entiende que esa palabra matriz se debe hallar más allá del sonido que pueden percibir, tal vez traspasados los límites del silencio, que para Gamoneda es «[...] el espacio de la memoria, el de la duda, el del miedo... [...] es un modo de existir». ${ }^{21}$

Esta dialéctica entre lo exotérico, la realidad común visible, y lo esotérico, la realidad interior invisible, ha existido a lo largo de todos los tiempos, aunque adaptada a la estética postmoderna de la que Gamoneda es heredero. A saber, se trata de una recuperación a través del recuerdo impostor de una historia en descomposición para sublimarla con una vuelta a un origen depurado. De hecho, volver la mirada hacia el pasado ha sido la constante que ha detectado Fredric Jameson en lo formal y en lo coyuntural en la postmodernidad del tercer tercio del siglo XX. Es obvio que el crítico estadounidense cree que esa vuelta a la historia, producto de la saturación de la novedad propia de la era moderna, recupera de una manera tan impostada el pasado que lo hace desaparecer tal y como era para depurarlo estéticamente según los gustos del presente. Así lo enuncia: «In the

$\overline{{ }^{21} \text { En A. Gamoneda, op. cit., p. } 184}$ cuando el oprimido sólo puede expresarse en la lengua del opresor, ésta se torna una lengua revolucionaria» (p. 159). ${ }^{59}$ Es una subversión del lenguaje del poder, tan exiguo en sus significaciones.

Por ello cabe decir que se articulan una serie de discursos a lo largo de su obra que están relacionados con esta evolución ideológica que él mismo marca. Desde Primeros poemas hasta Blues castellano se puede apreciar ese tránsito que va desde un tono intimista y evocativo hasta el acento más social, pero todavía en una lengua poética que usa un lenguaje más figurativo y menos metafórico que el que vendrá posteriormente. Es uno que sigue relativamente cercano al del opresor para comunicar el desasosiego interior frente a la historia al máximo número de lectores. Lo curioso es que cuanto mayor es su compromiso con la sociedad y con lo referencial, más impotente y frustrado se siente de revivirlo y de comunicarlo. A partir de Exentos II hasta prácticamente el final de su obra, la misma aporía sucede pero a la inversa. El lenguaje se altera para captar y crear nuevos significados que sólo son descifrables por minorías formadas literariamente, no tanto por el gran lector. No obstante, es entonces cuando él busca con más anhelo un reencuentro con el otro desde la inmanencia. Quiere que la historia recomience, aunque lo vea extremadamente difícil, y por ello anhelaría una nueva palabra y discurso que puedan dar los elevados significados de una justicia universal. Ellos son irrepresentables dada la limitada naturaleza del lenguaje que existe, pero se metaforizan desde la música («música de los límites» en Libro del frío: v. 3) ${ }^{60}$, el silencio y los signos abstrusos («signos (...) vacíos» o «palabras incomprensibles» en Arden las pérdidas: vv. 1-5).61

59 En A. Gamoneda, «Sobre Nazim Hikmet, los negro spirituals y mi Blues castellano» en AAVV, Antonio Gamoneda, AAVV, Madrid, Calambur, 1993, p. 159. (También en El cuerpo de los símbolos, pp. 81-98)

${ }^{60}$ En op. cit., p. 372

${ }^{61}$ En Ibidem, p. 415

LECTURA Y SIGNO, 4 (2009), pp. 239-271 
poesía en Exentos I: «[...] la única poesía,/ es la que calla y aún ama este mundo,/ esta soledad que enloquece y despoja» (vv. 3-5). ${ }^{57}$ Este comentario metapoético lo opone a las ideas de transformación del mundo de Gabriel Celaya o de la «verdad práctica» como fin en sí misma de Louis Aragon y sus opuestas de Rafael Morales de una poesía que se justifique a sí misma tan sólo en la «belleza». Para él, el lenguaje lírico debe aspirar a romper con la escasez semántica del oficial. Mientras eso no suceda, el poder revelador del significante poético seguirá estando limitado por esa insuficiencia del significado. Así aparece en «Cuestión de instrumento» en Blues castellano:

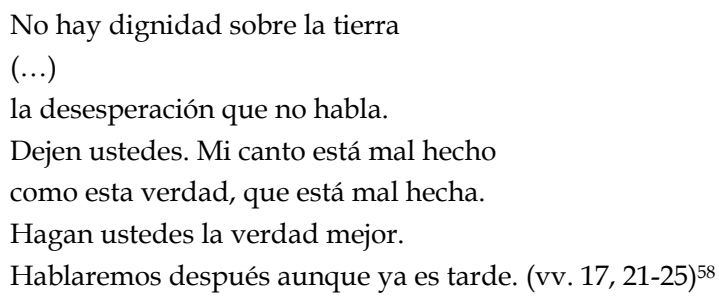

Estos versos nos conectan de nuevo con la idea de esa aspiración de pureza y de redención con un nuevo verbo ideal. Por otra parte, todo nuevo significante lingüístico supone la creación de nuevos significados. La realidad para Gamoneda está dentro del lenguaje ya que esa es una de las manifestaciones de la conciencia subjetiva a la que apela para llegar a una conciencia universal perfecta. No existe un referente objetivo ni tampoco un lenguaje unívoco. Por tanto, si se transforma el logos poético se puede pretender incluso alcanzar una nueva alternativa de dicción y de realidad que vayan más allá de lo que otros lenguajes literarios han podido expresar. Mientras la lírica no se consiga deslindar del lenguaje oficial denotativo y vacío, su capacidad connotativa sólo puede aspirar a violentar o a subvertir lo real, nunca a reemplazarlo. Ese tránsito intermedio anterior a la llegada de ese último lenguaje total, que aspira a depurarse hasta llegar a una palabra pura y originaria, es tan sólo un lenguaje revolucionario. Para ello parte del Orfeo negro de Jean Paul-Sartre: «[...]

\section{En A Gamoneda, op. cit., p. 87. \\ ${ }^{58}$ En Ibidem, p. 97.}

postmodern, then, the past itself has disappeared (along with the well-known "sense of the past" or historicity and collective memory)».22

En el fondo, eso es lo que hace Gamoneda, apropiarse del pasado para depurarlo en su peculiar y pesimista estética de la muerte. Absorbe esa tradición mística, la desmitifica, la humaniza y la reencamina hacia lo profano. Quiere con ello representar esta unión de los seres aquí en la tierra, que se augura imposible en la realidad. Este es un intento corrector de los excesos de la postmodernidad en cuanto a la alienación del ser, a los abusos de poder, al materialismo, al consumismo y al hedonismo. Es un itinerario que va del yo y del tú separados por el individualismo y el egoísmo a la solidaridad del nosotros y finalmente a la unificación del yo recompuesto. También es un desplazamiento de lo real a lo autorreferencial y de la necesidad del recuerdo con la memoria al miedo hacia el deceso futuro pasando por el eje axial que componen el binomio «verdad» y «mentira» en su obra maestra Descripción de la mentira (1975-6 y 2003). En su poética implosiona la confianza en el progreso y ese optimismo se convierte en negatividad hacia lo fútil del ser humano y de su identidad. Nuestro poeta considera que todos los intentos de evolución humanos dictados por el racionalismo se dirigen primero hacia la entropía y luego hacia la nada más absolutas.

En pocas palabras, es un yo lírico cuya identidad reside en el «tormento» frente «a una nada que se sufre, a un dolor que aniquila» de acuerdo con Diego Doncel. ${ }^{23}$ Él emprende un viaje melancólico de lo utópico, la búsqueda de la justicia social absoluta, a lo universal, la reintegración del hombre con el cosmos. Bajo esta actitud subyace un sentimiento íntimo de fracaso personal y de incapacidad de regeneración ética y moral. La crítica a la injusticia se convierte en crisis personal y se abre en una estructura trimembre. Primero la agnosis, el descubrimiento de un

22 En F. Jameson, Postmodernism, or, The Cultural Logic of Late Capitalism, Durham, Duke University Press, 1991, p. 309.

23 En D. Doncel, «Las experiencias de Antonio Gamoneda» en AAVV, Antonio Gamoneda, Madrid, Calambur, 1993, p. 13.

LECTURA Y SIGNO, 4 (2009), pp. 239-271 
problema identitario y su consiguiente purgación para depurarse en esa historia convencional. Segundo, la crisis hacia una iluminación verbal y lógica en esa interiorización o ultrahistoria. Tercero y último, el fallido intento de alcanzar esa catarsis inmanente y esa unión frustrada con la madre en el pasado ideal de la gran Historia del ser. Es el itinerario canónico de la mística cristiana desde una visión agnóstica ante el imperio destructor de la muerte.

Hay que destacar que hay tres vectores que unidos forman el cañamazo estructural de su viaje poético y ontológico en espiral hacia esa nada que los místicos veían como un estado de unidad y de plenitud del ser consigo mismo y con el cosmos. Se expresaba desencarnando la palabra hasta alcanzar los máximos niveles de depuración en el significante y en el significado que nos permite el lenguaje convencional. Es una doble actitud entre lo órfico, la prospección en el ser, y lo hermético, la que se produce en el lenguaje, según Gerald Bruns. ${ }^{24}$ El primer vector es la paulatina depuración de los modos de la historia gobernados por un silente «dios» en minúscula. Son representados por las nociones de tiempo y de espacio hacia ese pasado arquetípico de la humanidad. Desde él se pudiera reconducir la historia referencial hacia una Historia ideal. Ello se produce a través del solipsismo o ultrahistoria del ser. El segundo es el proceso de depuración de la palabra en busca de un nuevo logos que defina y redima el nuevo mundo y ontos, el ser. El tercero lo constituyen sus ideas de un proceso nostálgico hacia el origen representado por la vuelta a la madre biológica y a la natural. La conclusión, derivada por síntesis de las anteriores ideas, es que se trata de un proceso de evasión frente al materialismo moderno y de recuperación de la igualdad humana desde una ética y una estética místicas en las que el auténtico eje es el descubrimiento del fracaso de la vida en la muerte.

${ }^{24}$ En Gerald Bruns, Modern Poetry and the Idea of Language: A Critical and Historical Study, New Haven and London, Yale University Press, 1974, pp. 1-7, 232-262.
En Exentos III (1990-2003 y 2004) ese pasado intemporal es el de un espacio agrario con sombras y luz invisible. Es el de la infancia en la que ya se está adentrando: «Esta hora no es tiempo; sólo existe el pasado/ y algunos rostros invisibles» (Ibid., p. 516).55 Como colofón, en Mudanzas (1961-2003) se apela a ese «dios» de justicia social con poca esperanza además de hacerse un recuento de plantas y comestibles relacionados con la magia que ayudan al hombre a encontrar potencialidades taumatúrgicas y visionarias en un diario apócrifo. Con esta técnica epistolar, el tono se convierte en uno más lírico y menos abstracto aunque con una forma erudita a modo de criterio de autoridad. Es interesante ver cómo se relacionan lo falsamente empírico con lo poético, y cómo la especulación intuitiva de este acaba subvirtiendo y violentando el discurso racionalista de aquel. Tal vez es el reconocimiento de que sólo desde fuerzas paranormales se puede cambiar o modificar una historia que la lógica ha destruido.

Con ello, su poética pretende ser un doble viaje, primero hacia el futuro, el del deceso, y luego hacia el pasado, un renacer para recomenzar la historia. Es un proceso cíclico ideal que se detiene en la frustrada experiencia del poeta con la inapelable muerte.

\section{EL SONIDO, EL SILENCIO Y LA PALABRA}

Como el mismo Gamoneda señala, lo poético es «el resultado de una interiorización de la realidad más intensa que ninguna otra» así como una «fuerza de representación de la realidad interiorizada».56 Es, así pues, un viaje que transita por las lindes entre lo íntimo y lo místico. Le da por tanto una carta de naturaleza autorreferencial, como simple canto, al lenguaje poético que lo aparta del lenguaje convencional. Es un canto de soledad y de convocación de una nueva realidad: lo ideal es que el logos deje de significar y se convierta en ser. Así describe a este tipo de

${ }^{55}$ En Ibidem.

${ }^{56}$ En A. Gamoneda, «Poesía y conciencia: notas de una revisión», Ínsula, 204 (1963), p. 4.

LECTURA Y SIGNO, 4 (2009), pp. 239-271 
«Ahora mis ojos ven en el pasado: grandes flores inmóviles, madres atormentadas en sus hijos, líquenes fertilizados por la tristeza». ${ }^{51}$ Ese cronotopo se muestra con los líquenes de la suppa primigenia. Aparece un espacio rural dotado de toques místicos con luz y muerte. Luego hay sombras en los límites del crepúsculo, rostros que abandonan al yo lírico. Todo finaliza con la desaparición y el sucederse a sí mismo, reconociendo que la sabiduría total está en el olvido de lo histórico.

En la tercera fase se vuelve algo a la historia aunque deformado por el prisma de la extrañante luz de la revelación inmanente. Cecilia (2000-2004) vuelve a recuperar el amor en brazos de su nieta a la que ve ingresar en su madre en esa curiosa estética de la retracción. Es una parábola de ese proceso de reabsorción y posterior transformación del ser y de lo múltiple en lo uno. Está rodeada por esa luminosidad que precede a la muerte y que también puede venir después de ella. La vida es un hiato de oscuridad frente a esas dos posibles iluminaciones. Cecilia vive, para el yo lírico, en dos planos ya que le acompaña en el presente y es una encarnación de ese renacimiento en el pasado.

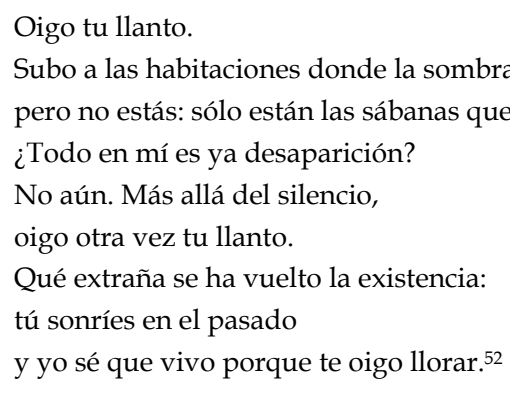

El presente, el pasado y el futuro se unen en el baile de generaciones en un espacio diluido de mística, amor y luminosidad. Es, como él nos dice, su «última flor» (v. 2) $)^{53}$ que crece en ese pretérito ideal: «Esta hora no es tiempo; sólo existe el pasado/ y algunos rostros invisibles».54

$$
\begin{aligned}
& { }^{51} \text { En Ibidem, p. } 454 . \\
& { }^{52} \text { En Ibidem, p. } 494 . \\
& { }^{33} \text { En Ibidem, p. } 510 . \\
& { }^{54} \text { En Ibidem, p. } 516 .
\end{aligned}
$$

\section{MODOS DEL «DIOS» INDIVIDUAL, DE LA HISTORIA, DEL TIEMPO Y DEL ESPACIO EN EL} YO LÍRICO

Según Álvaro Valverde este proceso en la obra de Gamoneda es un «[s]ilencio de la vida y silencio de la muerte que halla un correlato en el más duro silencio de Dios». ${ }^{25}$ Su obra es una búsqueda inmanente que suple a un «dios caído en el dolor», «inmóvil» (vv. 2, 5), ${ }^{26}$ que está «sucio de profecías» (v. 6) ${ }^{27}$ y que es «fugitivo» (v. 4) ${ }^{28}$ cuyas únicas manifestaciones son la nada, el vacío y la desesperanza. Por tanto, aunque lo anhele, el componente trascendente, la mística convencional, no existe. Para elaborar este discurso abstracto que represente a esta divinidad no eterna en el centro del ser, se construye un discurso autorreferencial saturado de símbolos y de metáforas para mostrar la gnosis. Se puede decir que es una mística reflexiva, del sujeto lírico hacia sí mismo, en su interior. El «peregrinaje vital en busca de la luz» que ve Pérez Lasheras es en la inmanencia. ${ }^{29}$ La única dirección hacia la que nos lleva este viático interior es la muerte, depurada y estetizada como la deseada antesala de un origen que se resiste a existir. Gamoneda está en la línea de un Martin Heidegger que veía que el tiempo es un «estar vuelto hacia la muerte» en la historicidad del ser.30 Así nos dice: «[...] mi comprensión de la vida consiste en una memoria mortal y en una perspectiva mortal, aunque no excluya el amor a la vida, ni el placer». ${ }^{31}$

La vida es un transcurso amargo por la historia convencional: su pupila lírica se detiene en la memoria, en las catastróficas consecuencias de la guerra civil

${ }^{25}$ En Á. Valverde, «La travesía del silencio (Pasión de la mirada)» en AAVV, Antonio Gamoneda, Madrid, Calambur, 1993, p. 105.

${ }^{26}$ En A. Gamoneda, Esta luz: poesía reunida (1947-2004), Epílogo de Miguel Casado, Barcelona, Galaxia Gutenberg-Círculo de Lectores, 2004, p. 43.

${ }^{27} \mathrm{Ibidem}, \mathrm{p} .47$.

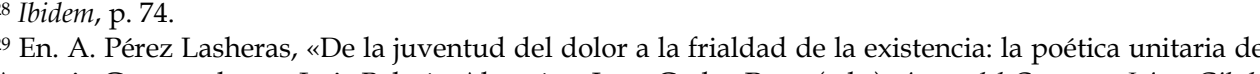
Antonio Gamoneda» en Luis Beltrán Almería y Juan Carlos Pueo (eds.), Actas del Congreso Jaime Gil de Biedma y su generación poética, Vol. II, Zaragoza, Diputación General de Aragón, 1996, p. 660.

30 En M. Heidegger, Ser y tiempo, Traducción, prólogo y notas de Jorge Eduardo Rivera C., Madrid

Trotta, 2003, p. 402.
31 En S. Martínez, «Antonio Gamoneda: “La poesía sirve para nombrar lo desconocido”.», Lateral, 83 (noviembre 2001), p. 9. 
española sobre los humanos y en la injusticia social en general. La ultrahistoria, o proceso solipsista, es manifestada a través del paso de la verdad oficial a la mentira ideal con la evocación de las figuras del padre y de la madre en Descripción de la mentira. Esa mentira es el nuevo discurso que nos debiera de abrir un nuevo saber en los albores de la muerte. Es una apertura epistemológica de la insuficiente razón convencional. Aun así, como ella va más allá de todo discurso racional, sólo se puede manifestar a través de imágenes que representen el silencio, donde está ese saber total que la imperfección de los humanos no puede percibir. Si consideramos que más allá de la materia pudiera estar la realidad posterior a la muerte, su expresión debiera estar en el ultrasonido, en el espacio del silencio. Como salvación frente a la incapacidad de aprehender esta otra realidad se centra en las figuras de la madre, del padre ausente que germinará su vida entre sus piernas, del origen global del mundo y de la vida en esa Historia ideal que se duda que se vaya a producir de verdad.

Para articular el contexto cronotópico de este itinerario, Gamoneda se vale de una diversidad de tiempos que expresan lo proteico de este proceso interior. Él mismo los enumeró en ocho del siguiente modo, de una manera más intuitiva que reflexiva. Por un lado, para el poema, primero el gramatical o de la sintaxis; segundo el físico, el que materializa en la historia el acto de escribir el poema; y tercero el de la conducta, la dimensión oral, la estructura musical. Por otra parte, para el poeta se ven el de la memoria del pasado, el del miedo al futuro y el que supone la confluencia de los dos en el momento de la contemplación en ese presente que «fugit irreparabile», que huye para siempre. ${ }^{32}$ También, según él, en el propio discurso se pueden implicar el futuro y el pasado. ${ }^{33}$ Lo que parece claro, de manera mucho más sintética en cuanto a lo ideológico, es que se evoluciona de un tiempo que mira hacia un pasado traumático, el histórico de la posguerra, a otro que mira hacia un futuro desolador, el de la muerte, que se desearía que llevara a los humanos a un pasado

32 En F. Martínez García, Gamoneda, una poética temporalizada en el espacio leonés, León, Universidad de León, 1991, p. 40.

${ }_{33}$ Ibidem, pp. 40, 46 pobreza vamos hacia la pureza de los límites: «Alguien ha entrado en la memoria blanca, en la inmovilidad del corazón./ Veo una luz debajo de la niebla y la dulzura del error me hace cerrar los ojos./ Es la ebriedad de la melancolía; como acercar el rostro a una rosa enferma, indecisa entre el perfume y la muerte.»47

Son un tiempo y un espacio inexistentes que sólo cobran dimensiones en esa infancia estetizada y en los amores perdidos: «Esta hora no existe, esta ciudad no existe, yo no veo estos álamos, su geometría en el rocío./ Sin embargo, éstos son los álamos extinguidos, vértigo de mi infancia./ Ah jardines, ah números».48 Remembranzas de amores melancólicos que llevan a reflexiones sobre la dialéctica que dinamiza la creación y la existencia: el eterno ciclo del eros («tu lengua») y del tánatos («la sombra»). El uno, movimiento de perpetuación, no se puede entender sin el otro, el de destrucción y entrada a un nuevo estadio generacional. Son las dos caras del sempiterno movimiento cíclico de la vida.

$$
\begin{aligned}
& \text { Ha venido tu lengua; está en mi boca } \\
& \text { como una fruta en la melancolía. } \\
& \text { Ten piedad en mi boca, liba, lame, } \\
& \text { amor mío, la sombra. }{ }^{49}
\end{aligned}
$$

La agonía se representa ante el muro que separa la muerte de la vida, ante el agua inmóvil y la blancura del final. Todo acaba sin esperanza en los líquenes del origen en lo invisible, en una nada en otra edad, la del origen, cuando el yo lírico arde con llama de depuradora pasión esotérica: «Ardes bajo las túnicas carnales./ Ha sido inútil la sutura negra:/ no hay agua en ti. Todas las fuentes manan en otra edad [...]» (vv. 1-3). ${ }^{50}$ Ello mientras va viendo cómo su último rostro desaparece y sólo hay luz ante sus ojos.

El cuarto y último libro de poemas es Arden las pérdidas (1993-2003 y 2004) en el que se insiste en ir a la muerte a través de la infancia, de la madre y de otro tiempo:

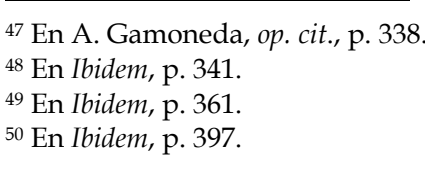


El segundo es Lápidas (1977-1986 y 2003). Su título es un signo disémico típico de Carlos Bousoño (Teoría) como puede ser el de la madre biológica y natural: su doble connotación alude a la muerte y a su carácter casi aforístico. Lápidas son también las frases con valor gnómico, apotegmático, sapiencial. En esta obra continúa ese descenso hacia la mentira redentora en la madre y ante la muerte. El espacio es interior y el tiempo se revierte, violentando la lógica tradicional. Ambos están presididos por recuerdos de infancia y presagios de muerte inminente. Gamoneda predica la redención de los oprimidos pero acaba descubriendo que «dios» tiene una máscara para ocultarse. Cuando esta cae, sólo se advierte el vacío: «Cae/ la máscara de dios: no había rostro./ ¿Quién habla aún al corazón amarillo?» (vv. 6-7). ${ }^{44}$ Es el silencio divino y una expresión de fe agnóstica. El origen se define por su ausencia, su invisibilidad y su incomunicabilidad y él no tiene semilla para reengendrar como la paz no tiene esperanza.

El tercero es el Libro del frío (1986-1992, 1998 y 2004). En él nos advierte en una clara referencia metapoética del tránsito espacial y temático (articulados desde la nostalgia al deseo inmanente) que se ha efectuado desde el primer ciclo poético hasta el segundo: «Hubo un tiempo en que mis únicas pasiones eran la pobreza y la lluvia./ Ahora siento la pureza de los límites y mi pasión no existiría si supiese su nombre». ${ }^{45}$ Se trata del mismo proceso en espiral que se va viendo en este y en los dos anteriores poemarios. Mientras se encamina hacia ese olvido el yo lírico se desdobla en el «vigilante de la nieve», una especie de alter ego, en la vejez y ante la muerte, que quiere volver al amor materno. Ese personaje o esa máscara del yo lírico fue inspirado por Jorge Pedrero, un obrero del vidrio y pintor que se suicidó, al que Gamoneda una vez se encontró diciendo solo que estaba cuidando de la nieve. Como bien afirma el poeta en El cuerpo de los símbolos: «No se equivocan plenariamente los críticos [...]: quizá alguna vez yo he sido o voy a ser el vigilante de la nieve».46 De la

${ }^{44}$ En Ibidem, p. 293

${ }^{45}$ En Ibidem, p. 335

${ }^{46}$ En A. Gamoneda, El cuerpo de los símbolos, Murcia, Huerga y Fierro, 1997, p. 233. ideal en el origen. Por añadidura, en su obra poética el espacio se va diluyendo desde uno de soledad y de desasosiego interior frente a la realidad y a los recuerdos hacia un tú amatorio, y de búsqueda baldía de reconciliación con el ser humano, hasta otro luctuoso y autorreferencial: «Hay úlceras en la pureza, vamos/ de lo visible a lo invisible».34 Estos versos nos muestran los estratos interiores de un ser que se descompone hacia un pasado y un conocimiento ideales que desembocan en la muerte. Finalmente, la nieta del poeta, Cecilia, le descubre un nuevo amor a las puertas de la extinción y de los reinos de lo invisible. Estas categorizaciones espaciotemporales se podrían sintetizar así en este viaje interior del ser hacia la nada.

En sus Primeros poemas: la tierra y los labios (1947-1953 y 2003) se articulan un tiempo y espacio que son configurados por una mente evocativa, llena de soledades por las ausencias del padre y las desapariciones de la guerra. Esa se define por un pasado de frustraciones amatorias hacia un tú no especificado. El tiempo se proyecta hacia un presente congelado en el dolor que tiene premoniciones de un futuro predeterminado por un destino de muerte. Así pues, se prevé que el yo lírico se convertirá en un homo viator hacia la desaparición en el fondo de su mente o inmanencia. Sublevación inmóvil (1953-1959 y 2003), que para Valverde «va de lo real o exterior [...] a lo simbólico o interior [...]», nos muestra ese «dios» íntimo en minúscula que se encuentra en la inmovilidad del centro del yo. ${ }^{35}$ Él es la estación de término de este viaje interior. A él le lleva su desconfianza y frustración ante la historia y el dolor producido por la pérdida de la alteridad en forma de un amor. La presencia de los espacios rurales en su tercera parte recupera las esencias de un pasado que vuelve hacia el presente congelado y deformado por una memoria que adultera, recrea e idealiza lo vivido. El tiempo mental sigue en este proceso de desplazamiento desde ese pasado agónico hasta ese futuro de aniquilación pasando por un presente referencial que no evoluciona. Es allí donde sitúa su discurso poético

${ }^{34}$ En A. Gamoneda, op. cit., pp. 4-5.

35 En Á. Valverde, «La poesía de Antonio Gamoneda (una lectura)», Cuadernos Hispanoamericanos, 522 (1993), p. 137.

LECTURA Y SIGNO, 4 (2009), pp. 239-271 
el yo lírico. Esta noción de impasse temporal la representa el mármol: «En la columna viva, / el fugitivo tiempo/ se detiene. [...]» (vv. 5-7). ${ }^{36}$

Exentos I (1959-1960 y 2003) continúa la evocación de este amor nostálgico de juventud. Es el único tiempo que se ha podido aprehender gracias al recuerdo, el resto escapan de la absorción de la muerte: «Ah verdadero amor, / qué sensación de tiempo/ poseído [...]» (vv. 5-7). ${ }^{37}$ El silencio del corazón lo preside. No obstante, ya empieza a aparecer la figura de la madre, a la que se va a encaminar pronto en un proceso de retracción hacia el arkhé. Blues castellano (1961-1966 y 2004) es culminación de la anterior etapa y un primer punto de inflexión. Del binomio yo y tú, que no desaparece del todo, vamos al nosotros, la solidaridad frente a la desgracia ajena a ritmo de blues y de gospel. No obstante, sigue sin vislumbrarse la esperanza. Las evocaciones de la infancia, de la madre, de la destrucción de la guerra y del desánimo de la posguerra se poetizan para mejorar un presente de impiedad.

Exentos II: Pasión de la mirada (1963-1970 y 2003) abriría el segundo ciclo en el que empieza la «retracción», palabra muy manida por la crítica gamonediana y por él mismo. ${ }^{38}$ El espacio y el tiempo se contraen para empezar el repliegue desde la injusticia histórica:

Espacio siempre frente al tiempo. No

hay mayor lentitud que esta paciencia

que $[\ldots]$

[...] habita en la mirada

de la desolación (vv. 1-5).39

Asistimos a un espacio cóncavo, el del ser que se reabsorbe y que se abre hacia la muerte. Es un espacio invertido y teratológico, en el que animales extraños representan la depuración del yo ante el nuevo conocimiento. El tiempo gira su cronología lentamente desde este presente evocativo de un pasado frustrado hasta

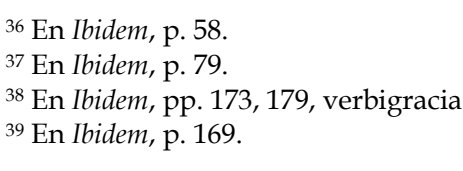

${ }^{38}$ En Ibidem, pp. 173, 179, verbigracia.

${ }^{39}$ En Ibidem, p. 169

ese pasado ideal instalado en el olvido de la vida. Es la hipotética vuelta a un origen que desearía que se reiniciara la historia para poderla redirigir hacia una noción maniquea de un bien universal. Este proceso se muestra detalladamente en los cuatro siguientes poemarios que avanzan en espiral y que abren la técnica del fragmentarismo tanto en lo formal como en el contenido de escisión del ser en busca de su otro yo hacia la eternidad.

El primero es Descripción de la mentira (1975-1976 y 2003). En él ya estamos en un espacio de depuración somática y en un tiempo que fluye en dirección contraria a la cronología convencional en busca de la muerte en un pasado ideal. Para ello el yo lírico escenifica un itinerario trascendente similar al proceso de purgación, iluminación y unión que experimentan los místicos cristianos. El yo poético se evade de la historia y de la verdad social del franquismo en «Un país cerrado», ${ }^{40}$ para entrar en el solipsismo de la ultrahistoria del ser en la época de la apertura democrática en «Un país sin verdad», ${ }^{41}$ en referencia a la «verdad oficial impuesta». Busca al padre y a la madre en el momento de la mentira previa a la muerte en un pasado recreado del origen.

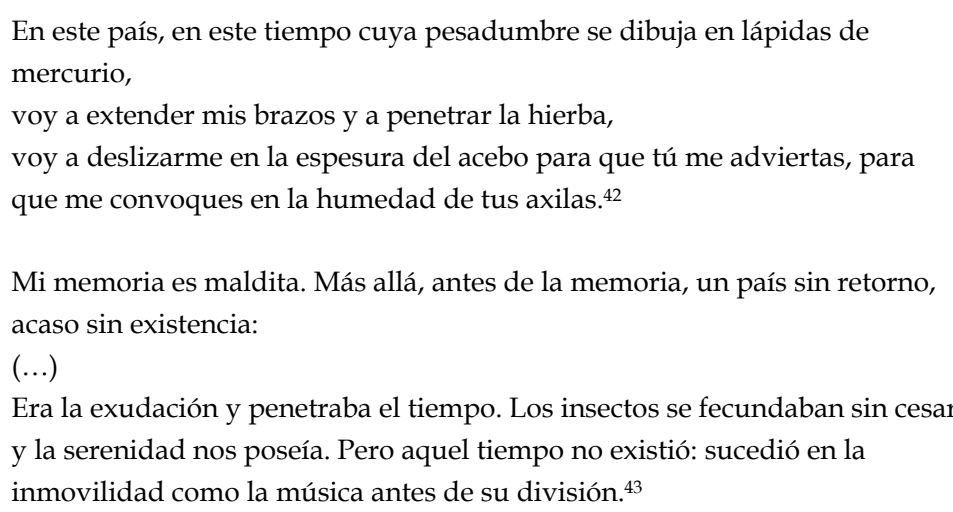

\section{En Ibidem, p. 178 \\ 2 En \\ ${ }^{43}$ En Ibidem, p. 183}

LECTURA Y SIGNO, 4 (2009), pp. 239-271 
No hay metáforas. Sí, comparaciones. Pocas alegorías. Y una evocación de la verdad de las cosas, una sinceridad expresada y recibida por medio de un lenguaje sin adornos: las palabras comunes del hablante instruido, con alguna concesión ocasional al color local ${ }^{22}$. Sus nombres, sobre todo, y sus adjetivos son a un tiempo precisos y evocadores: sus connotaciones van siempre en dirección a lo más íntimo del hombre, hacia su encuentro con Dios - más íntimo al hombre que el hombre mismo 23 - : «la casa» llama ahora al hogar, a lo tangible, a las raíces, y también al cuerpo que alberga un alma; «el camino» es el actuar comprometido y arriesgado; «el tapiz» es el haz y el envés, lo que ve uno y lo que ven los demás de la propia vida, lo que vemos nosotros y lo que ve Dios; «el crepúsculo», «los sueños», «la nostalgia», «los pasos»... y «el cáncer»: memento, homo! ¡Y los adjetivos: desde las dos primeras palabras, «Lo importante» (p. 9), hasta las últimas páginas, «este abrupto final» (p. 42), «aquella casa» (p. 45).

De hecho, prácticamente, cada poema podría condensarse en uno de esos sustantivos de uso común, que van preñados de los sentimientos del poeta. Así, los títulos - los poemas vienen sin él: en el índice se denominan con el primer versopodrían muy bien ser: «Mi voz» (p. 9, v. 6), «La realidad» $(10,1)$, «Una salida» $(11,4)$, «Este tapiz» $(12,5)$, «La corriente» $(13,4)$, «Saber terminar» $(14,2)$, «La nostalgia» $(15$, $1)$, «LA VIDA» $(16,1)$, «Errores» $(17,1)$, «Sueños» $(18,10)$, «Crepúsculo» $(19,13)$, «Sola» $(20,13)$, «El sueño» $(21,8)$, «Camino» $(22,8)$, «Un cáncer» $(23,4)$, «La mano» $(24,7)$, «Demasiado» $(25,1)$, «Campanas» $(26,2)$, «Alegría» $(27,11)$, «Agradecida» $(28,12)$, «Lo que busco» $(29,5)$, «La hora de morir» $(30,2)$, «La luz» $(31,18)$, «La encontradiza» $(32,13)$, «El dolor» $(33,6)$, «Mi caso» $(34,1)$, «Disfrutar» $(35,28)$, «iOjalá! » $(37,10)$, «Un gran banquete» $(38,9)$, «La pesca milagrosa» $(39,13)$, «Las sandalias» $(40,1)$, «Aquel silencio tuyo» $(41,9)$, «Este abrupto final» $(42,18)$, «Tu

22 Véase el empleo del término «reboño» con la acepción de 'canal' o 'acequia'. El DRAE no la trae en su última edición (2001). En las 12 ediciones que median entre los años 1925 y 1992 viene con el significado de: « [En] Cantabria. Suciedad o fango depositado en el cauce del molino».

${ }^{23}$ Tu autem eras interior intimo meo (San Agustín, Confessiones, III, 6, 11).
El recuerdo le lleva a ver cómo se acabó la inocencia y empezó la historia de injusticia de la que se trata de huir. La salida por la vagina materna dilatada y la sequedad de los pechos maternos son los últimos momentos en que el yo lírico era libre y puro. Es una invitación a empezar por allí otra vez: «[...] y los muslos que yo conocí con mi lengua se cerraron y los pezones que estuvieron en mis labios se endurecieron como sílice». ${ }^{76}$ Asimismo, en su obra se alude a que el renacimiento se ha de producir desde las aguas. Ellas tienen un doble significado: el de la charca originaria de la que nació la vida y el líquido amniótico materno, simbolizados también por la presencia de los «líquenes»,77 de los «légamos»,78 de las «aguas inmóviles» ${ }^{79} \mathrm{o}$ de las «aguas coléricas». ${ }^{80} \mathrm{El}$ «tú» tanto se puede referir al padre como a la madre ya que el poeta va dirigiéndose a ellos sin dar previo aviso. Es interesante esta estrategia andrógina: nos muestra las dos caras de un mismo ser, lo masculino y lo femenino: «Tu voz en dátiles sangrientos surge de las sustancias distribuidas sobre el mar $[\ldots] »^{81} \mathrm{o}$ «Días de labranza extendidos más allá de las aguas/ [...]/ así es el mundo delante de mis ojos». .2

La figura de la madre, en ese proceso de abstracción paulatina que va sufriendo su obra, se va ahuesando, se convierte en un puro espectro, en un motor de vida sin figura. El carácter surreal de la obra, clara deudora de ese movimiento vanguardista, como toda mística moderna, se incrementa en Lápidas: «Madre indistinta, líbrame de quien se oculta entre palomas, cubre mi rostro, sálvame del viernes» (v. 3). ${ }^{83}$ Así se expresa en el Libro del frío, en donde el paso de la existencia a la inexistencia, un ciclo de generación, destrucción y regeneración, está marcado por esta figura anfibológica: «La inexistencia es hueca como las máscaras y su visión es

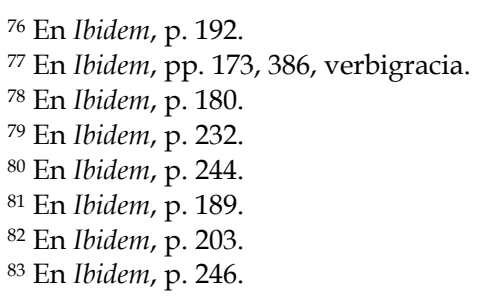


lívida, pero tú oyes el grito de las madres del agua y acaricias los ojos que vieron la inexistencia». ${ }^{84}$ En Arden las pérdidas se identifican las aguas con la muerte y el renacer en la vulva materna, que recordemos que es también una encarnación de la mandorla en donde está el pantocrátor cristiano iluminando la creación del mundo. Es ese punto de intersección entre la tierra y el cielo, lo inmanente y lo trascendente, el día y la noche, lo material y lo espiritual o lo masculino y lo femenino: «Vi la vagina maternal que llora y el dolor en una cuenca dorada [...]» (v. 2). ${ }^{85}$ La vida convencional, la muerte y la vida eterna se funden en un punto en la totalidad de la visión poética:

\section{Miro mi desnudez. Contemplo la aparición de las heridas blancas. \\ Envuelto en sábanas mortales, \\ bebo en las aguas femeninas \\ la dulzura y la sombra. ${ }^{86}$}

Como colofón, en Cecilia le acaba recomendando a su nieta, la cual le devuelve fugazmente la ilusión por la vida, que vuelva hacia su madre como símbolo de perpetuación de la especie a través de la mujer: «Entra en tu madre y abre en ella tus párpados,/ entra despacio en su corazón./ Vuelve a ser fruto en el silencio». [...] (vv. $1-3) .87$

\section{CONCLUSIONES}

En conclusión, aunque lo niegue, Antonio Gamoneda está siguiendo los patrones de la mística sincrética cuando construye su entramado poético. Esta vuelta al pasado ideal para recomenzar la Historia y esta dislocación de las nociones convencionales de Dios («dios» para él, y para su amigo José Ángel Valente), ser inmanente, tiempo en reversión y espacio interior, ambos de la conciencia, además de las de una palabra y de una madre originarias, pretenden buscar un modelo

$$
\begin{aligned}
& { }^{84} \text { En Ibidem, p. } 357 . \\
& 85 \text { En Ibidem, p. } 421 . \\
& { }^{86} \text { En Ibidem, p. } 426 . \\
& { }^{87} \text { En Ibidem, p. } 491 .
\end{aligned}
$$

Es el verbo creador y redentor del poeta.

\section{MEMENTO MORI, CONTEMPLANDO EL ROSTRO DE LA MUERTE}

En 2003 publica Las casas abandonadas. Después de tantear el camino en busca de su voz - su yo y su estilo- (Los primeros avisos); después de haber recorrido con esfuerzo un sendero a través del bosque - desde la selva hasta el jardín - trabajando su yo por la ascesis, y su estilo por el esfuerzo perseverante de desbroce y de poda (Recuerda a un bosque), en Las casas abandonadas la vida ha llegado a plenitud serena, la forma ha encontrado su madurez en la desnudez.

Las casas abandonadas tratan del final del camino, la muerte, que, cuando llega, deja la casa vacía, y el cuerpo vacío (la casa es la imagen del cuerpo, habitado o «abandonado»). En paralelo, el estilo del autor se ha ido desprendiendo también de lo material, de lo adjetivo: ya no se viste con joyas prestadas - adiós a las referencias cultas, a las palabras mágicas, a la sujeción a una misma estrofa-. Su arte se ha hecho pobre para hacerse rico:

$$
\begin{aligned}
& \text { Lo importante es la voz, dar con la voz } \\
& \text { de aquel que vive dentro y al que sólo } \\
& \text { presentimos a veces, como en sueños. } \\
& \text { Tú me tienes a mí, tú que no esperas } \\
& \text { más que la hora de morir: permite } \\
& \text { que te preste mi voz, que sea útil (p. 9). }
\end{aligned}
$$

Sólo queda el ritmo y la palabra más ajustada. No hay rima, no hay una estrofa común. Sólo queda el endecasílabo disciplinado y andadero. En tan solo dos ocasiones combina los versos de once sílabas con sendos heptasílabos, tratados como si fueran hemistiquios huérfanos, con el mismo acento mayor en la sexta: «que esto ha sido muy corto, que ha durado / menos de lo debido» (p. 19, vv. 4-5); y

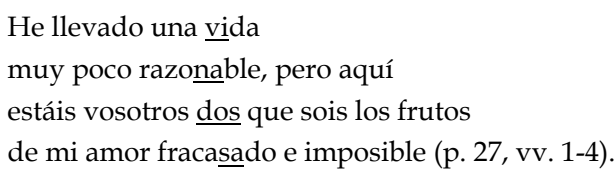


una buena pesadilla / te puedo ofrecer esta». ¿Tú?, ¿yo?, ¿o acaso es el lector el interpelado?

Sólo el 'yo' quiere decir yo en la estrofa en que, al final del libro, el poeta se sincera de esta manera:

$$
\begin{aligned}
& \text { También tengo otros bosques más amables } \\
& \text { que, por cierto, me suele gustar menos } \\
& \text { contaros, recordar: como si hubiese } \\
& \text { un extraño pudor que me impidiese } \\
& \text { hablar con alegría de la vida, de las cosas } \\
& \text { que debo agradecer, por la que vivo. }
\end{aligned}
$$

Pero, en el centro del libro, la lírica se hace 'lírica del tú', un tú que tiene nombre, María - lo avisaba la dedicatoria: «A María» - . Es amor en coloquio con la persona amada. Un cambio de tono, una inevitable embriaguez se desata al evocar a su mujer, a partir de estos versos:

$$
\begin{aligned}
& \text { Qué clase de locura es este bosque } \\
& \text { que me ofreces ahora, los jardines } \\
& \text { que sólo tienes tú y en que pretendes } \\
& \text { me pierda, te me entregue. Ya se adensa } \\
& \text { la selva tras de mí como una noche } \\
& \text { cerrada y sin caminos. No me queda } \\
& \text { ninguna escapatoria; ni la quiero. }
\end{aligned}
$$

Finalmente, me place resaltar que la sobria contención de Manuel Ballesteros no consigue ocultarnos la filosofía de su escribir, su poética personal, que manifiesta casi sin darse cuenta en la siguiente composición (séame permitido desvelarlo por medio de unas atrevidas trasposiciones que el lector también habrá sabido leer tras los velos de las palabras):

$$
\begin{aligned}
& \text { Un bosque de palabras son tus versos [mis versos], } \\
& \text { imágenes sonámbulas que vienen } \\
& \text { de lejos hacia ti [hacia mí] y que despiertan, } \\
& \text { sin orden ni concierto, muchas cosas } \\
& \text { antiguas que creías [que creía] olvidadas, } \\
& \text { que estaban olvidadas y aguardaban } \\
& \text { tan sólo a que tu voz [mi voz] las rescatase. }
\end{aligned}
$$

idealista de «justicia social». Esa justicia se postula en un más allá tan difícil de alcanzar como en nuestro mundo real. Su obra en general es una corrección postmoderna a la globalización, al hiperconsumismo y a la desnaturalización de la realidad por parte de la cultura de masas. Es también un alegato en contra de los desórdenes, abusos y corruptelas del poder y de su sometimiento de los libres impulsos individuales en la historia. Frente a ellos, se erige la evasión esotérica del yo lírico en esta poesía de conocimiento interior. La única «verdad» para nuestro poeta es la muerte y la «mentira» es una ilusión de eternidad que no se llega a plasmar en esta obra por insuficiencias del lenguaje y de nuestro conocimiento. Tal vez, estos últimos versos del Libro del frío son lo máximo que ha podido captar su diapasón poético: «[...]/ es la agonía y la serenidad./ Quizá soy transparente y ya estoy solo sin saberlo. En cualquier caso, ya/ la única sabiduría es el olvido». 88
${ }_{88}^{8 n}$ En Ibidem, p. 475 .

LECTURA Y SIGNO, 4 (2009), pp. 239-271 


\section{BIBLIOGRAFÍA.}

AAVV., Antonio Gamoneda, Madrid, Calambur, 1993.

BOUSOÑO, C., Teoría de la expresión poética (hacia una explicación del fenómeno lírico a través de textos españoles), 2 vols., Madrid, Gredos, 1985.

BRUNS, G., Modern Poetry and the Idea of Language: A Critical and Historical Study., New Haven and London, Yale University Press, 1974.

CANDAU, A., «Antonio Gamoneda: la conciencia y las formas de la ironía», Hispanic Review, 62.1 (1994), pp. 77-91.

CASADO, M., «Un ejercicio de comparación: “Lapidario" y “Lápidas”» en AAVV, Antonio Gamoneda, Madrid, Calambur, 1993, pp. 119-134.

CASTRO FLÓREZ, F., «Manos de tierra» en AAVV, Antonio Gamoneda, Madrid, Calambur, 1993, pp. 29-48

COLINAS, A., «Lápidas, de Antonio Gamoneda: un humanismo para el fin de siglo», Ínsula, 487 (1987), pp. 16-17.

DEBICKI, A., Poetry of Discovery: The Spanish Generation of 1956-1971, Lexington, Ky, The University Press of Kentucky, 1982.

_. Historia de la poesía española del siglo XX: desde la modernidad hasta el presente, Madrid, Gredos, 1997.

DIEGO, J. M., «Antonio Gamoneda, el valor de la marginalidad», Ínsula, 543 (1992), pp. 11-12.

DONCEL, D., «Las experiencias de Antonio Gamoneda» en AAVV, Antonio Gamoneda, Madrid, Calambur, 1993, pp. 9-16.

GAMONEDA, A. y F. R. DE LA FLOR (eds.), «Preliminar» en Sílabas negras, Salamanca, Ediciones Universidad de Salamanca y Patrimonio Nacional, 2006, pp. 7-96.

GAMONEDA, A., Esta luz: poesía reunida (1947-2004), Epílogo de Miguel Casado, Barcelona, Galaxia Gutenberg-Círculo de Lectores, 2004. rima), pero se apoya en la recurrencia de la medida (once sílabas siempre bien contadas), y en muchos casos también - dejándose llevar por el oído más que por el lápiz- en una cadencia regular. De todas formas, donde está verdaderamente presente la delicada y oportuna repetición poética es en los nombres, en los objetos nombrados por sustantivos, siempre los mismos: selva, bosque, jardín, nostalgia, esperanza... y, sobre todo, en las distintas etapas de un caminar esforzado - ahora con entusiasmo, luego a contrapelo- que comienza y vuelve a comenzar una y mil veces.

Poesía en cierta medida épica: canta las pequeñas - ¿o grandes? - hazañas de un hombre - el hombre - a través del «camino de la vida» de que habla el primer verso, el sempiterno topos del iter vitae ${ }^{21}$. Pero es, todavía más, lírica. Habla de evoca, descubre, revela y suscita - sentimientos. En el primer canto la lírica es ‘lírica del $y o^{\prime}$, de un yo nunca mencionado, siempre escondido tras la figura del bosque o del jardín; o detrás de una frase impersonal:

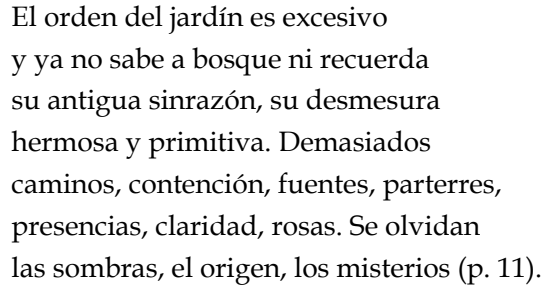

En los cantos III y IV también se examina y se exhorta el poeta a sí mismo con una forma de ocultamiento - ¿de pudor, de buena educación? - . El tú es yo. Y lo es, gramaticalmente, a través de esa virtualidad de que dispone la segunda persona para expresar lo mismo un impersonal («Tú caminas / por una senda que atraviesa un monte» (p. 45, vv. 1-2), que un indudable yo («Un bosque de palabras son tus versos», p. 57, v. 1). A veces el tú de Ballesteros no se sabe bien quién puede ser: «Si quieres

\footnotetext{
${ }^{2}$ Cfr. Roman Jakobson, «Lingüística y poética», Ensayos de lingüística general, Paris, 1963. ${ }_{21}^{1}$ Séneca, principalmente, entre otros lugares, en De brivitate vitae, 9, 5, y en la epístola Ad Lucilium, 14
} 
aderezó el nombre de manera que resultara un endecasílabo perfecto: «Éste que veis aquí, de rostro español y quevedesco, de negra guedeja y luenga barba, soy yo: $\underline{\text { don }}$

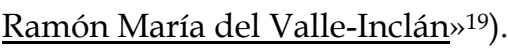

Ballesteros hace un uso personal de lo viejo: no sigue a los humanistas del Renacimiento que ya no copiaban del natural sino de los clásicos. Ballesteros, como los clásicos, copia del natural. Más, toma de los nuevos ese prurito de la «poesía pura» de no acopiar citas cultas, ni invocar autoridades del olimpo o del palacio o del catálogo de los héroes. Tampoco, como ellos, hace ya literatura de la literatura.

Esa misma tendencia, ensayada por otros desde finales del XIX, le lleva al verso libre, a la composición de siete versos libres, difícil de encasillar. Sin embargo, no sigue a la poesía pura en sus extremismos de racionalización $-\mathrm{y}$ consiguiente deshumanización -, sino que se inspira en ella al modo que lo hizo Juan Ramón, para depurar el verso y dar contundencia a lo sencillo. En la obra de Ballesteros abunda y manda la frase nominal. Hace su papel por todas partes, pero sobresale cerrando los versos finales de los poemas: una frase nominal conclusiva, compendiosa, que podría dar título a la composición. Así, la tarde. (p. 9), nuestros sueños. (p. 11), los misterios. (p.10), el fuego. (p. 14), y del mismo modo hasta el final Estos finales, que el autor puntúa con coma, bien podrían ir en algunos casos precedidos de los dos puntos que aún pondrían más de manifiesto el carácter de conclusión, de condensación de lo que sigue y acaba.

La sobriedad del verso es mesetaria. No hay rima, no hay hipérbaton, y no hay apenas metáforas (imágenes sí, muchas y bellas; y comparaciones, y una permanente alegoría).

Si la función poética del lenguaje se expresa mediante recurrencias o repeticiones, como propuso Jakobson ${ }^{20}$, Ballesteros prescinde de la más evidente (la

19 Así comienza su fabulosa autobiografía en «Juventud militante. Autobiografías», Alma Española, $\mathrm{n}^{\circ}$ 8, 27 de diciembre de 1903. (El subrayado es nuestro).
. «Poesía y conciencia: notas de una revisión», Ínsula, 204 (1963), p. 4

_. «Sobre Nazim Hikmet, los negro spirituals y mi Blues castellano» en AAVV, Antonio Gamoneda, AAVV, Madrid, Calambur, 1993, pp. 145-159. (También en El cuerpo de los símbolos, pp. 81-98)

_. El cuerpo de los símbolos, Murcia: Huerga y Fierro, 1997.

_. Valente: texto y contexto. Santiago de Compostela, Universidade de Santiago de Compostela, 2007.

GARCÍA JAMBRINA, L. (ed.), La promoción poética de los 50. Ángel González, José Manuel Caballero Bonald, Carlos Barral, José Agustín Goytisolo, Jaime Gil de Biedma, José Ángel Valente, Francisco Brines, Claudio Rodríguez, Madrid, Espasa Calpe, Colección Austral, 2000.

HASSAN, I., The Postmodern Turn: Essays in Postmodern Theory and Culture, Columbus, Ohio State University Press, 1987.

HEIDEGGER, M., Ser y tiempo, Traducción, prólogo y notas de Jorge Eduardo Rivera C., Madrid, Trotta, 2003.

JAMESON, F., Postmodernism, or, The Cultural Logic of Late Capitalism, Durham, Duke University Press, 1991.

LÓPEZ CASTRO, A., «Antonio Gamoneda: la poesía de la memoria», en Voces y memoria. Poetas leoneses del siglo XX, Valladolid, Junta de Castilla y León, 1999, pp. 151-189.

LYOTARD, J. F., The Postmodern Condition, 1979, Translated from French by Geoff Bennington and Brian Massumi, Minneapolis, University of Minnesota Press, 1993.

MARTíNEZ, S., «Antonio Gamoneda: “La poesía sirve para nombrar lo desconocido".», Lateral, 83 (noviembre 2001), pp. 8-9.

MARTÍNEZ GARCÍA, F., Gamoneda, una poética temporalizada en el espacio leonés, León, Universidad de León, 1991. 
MAYHEW, J., «Rhetoric and Truth in Gamoneda», in The Poetics of Self-Consciousness. Twentieth Century Spanish Poetry, Lewisburg, Bucknell University Press, London and Toronto, Associated University Presses, 1994, pp. 80-95.

MESTRE, J. C., «Sublevación inmóvil» en AAVV, Antonio Gamoneda, Madrid, Calambur, 1993, pp. 87-94.

MIRÓ, E., «Una colección y dos poetas: José Antonio Gabriel y Galán y Antonio Gamoneda», Ínsula, 377 (1978), pp. 6-7.

MOLINA, C. A., «Dos visiones épicas de lo contemporáneo», Camp de L’Arpa, 84-85 (1981), pp. 65-67.

ORTEGA, A., «La realidad plástica en Descripción de la mentira» en AAVV, Antonio Gamoneda, Madrid, Calambur, 1993, pp. 109-117.

ORTEGA, E., «La música de la oscuridad. Antonio Gamoneda», Campo de Agramante, 5 (2005), pp. 101-115.

PÉREZ LASHERAS, A., «De la juventud del dolor a la frialdad de la existencia: la poética unitaria de Antonio Gamoneda» en Luis Beltrán Almería y Juan Carlos Pueo (eds.), Actas del Congreso Jaime Gil de Biedma y su generación poética, Vol. II, Zaragoza, Diputación General de Aragón, 1996, pp. 655-664.

PUERTO, J. L., «El animal de la memoria» en AAVV, Antonio Gamoneda, Madrid, Calambur, 1993, pp. 17-27.

RODRÍGUEZ, I., «Una conversación con Antonio Gamoneda» en AAVV, Antonio Gamoneda, Madrid, Calambur, 1993, pp. 61-85.

RODRÍGUEZ PADRÓN, J., «Desnudo ante el agua inmóvil» en AAVV, Antonio Gamoneda, Madrid, Calambur, 1993, pp. 135-144.

SERRANO, P., «Gamoneda: la escasez y la necesidad», Letras Libres, 84 (2005), pp. 8487.

SILVER, P., La casa de Anteo: Ensayos de poética hispana (De Antonio Machado a Claudio Rodríguez), Versión española de Salustiano Masó, Madrid, Taurus, 1985. en selva, ora se aclara y ordena en jardín (paradiso). Selva y jardín se disputan el bosque en un tira-y-afloja, que es figura de una lucha interior: «las dos ciudades» combatiendo dentro del hombre ${ }^{18}$.

Si hubiera que encuadrar este poemario en un género literario, quizás habría que considerarlo heredero de las epístolas horacianas, atendiendo a la intención didáctico-moral: cada composición de Recuerda a un bosque tiene, además de una confesión, un mensaje discretamente sugerido.

El tomo se distribuye en cuatro cantos de doce poemas cada uno. Las estrofas son siempre de siete versos endecasílabos sin rima. El ritmo - a veces brillantemente conseguido- se logra gracias al metro muy cuidado, a veces cantabile en endecasílabos cuyo acento descarga en la $2^{\mathrm{a}}$ [ó, eventualmente, $3^{\mathrm{a}}$ ], la $6^{\mathrm{a}}$ y la $10^{\mathrm{a}}$ sílabas, que invitan a cantar partiendo cada verso en dos por la sexta:

$$
\begin{aligned}
& \text { El bosque y el jardín son las dos caras } \\
& \text { de la misma moneda. Una moneda } \\
& \text { que tiene por un lado un rostro amable, } \\
& \text { aseado, sonriente y por el otro } \\
& \text { un paisaje sombrío en el que habitan } \\
& \text { dormidas las imágenes de antaño, } \\
& \text { y, ㅁvos, los naufragios y los sueños (p. 17). }
\end{aligned}
$$

Los versos son frescos, naturales, aparentemente espontáneos. Pero son refinados. A un castellano, cuando versifica, fácilmente le acuden octosílabos a la boca y a la pluma - es su verso connatural y más arraigado-; el endecasílabo es verso de cultura, prestigiado desde Italia por Dante y Petrarca, e importado en España, definitivamente, a través de Boscán y Garcilaso; y adaptado a las posibilidades de nuestra lengua por este último mediante una adecuada distribución de los acentos. Desde entonces, el endecasílabo se ha hecho tan amable a nuestro oído que nos hemos acostumbrado a él, se ha hecho cómodo al escritor y al lector o, por mejor decir, al oyente: el polifacético Valle (que se llamaba Ramón Valle Peña) se

${ }_{18}$ Cfr. S. Agustín, De civitate Dei, XIV, 28. 
segunda vida en la fama. La evocación de la Biblia le conduce al campo de la lucha interior, al palenque donde se gana la tercera, que es «eternal y verdadera»15.

\section{DE VETERA ET NOVA: CON UN DECIR DEPURADO}

En Recuerda a un bosque, Manuel Ballesteros toma lo mejor de lo viejo y de lo nuevo en su poesía. Recuerda a un bosque es obra de madurez de un poeta maduro en la edad y en el ejercicio de las letras. El autor deja traslucir en su obra un profundo conocimiento de las humanidades y firmes convicciones religiosas que, lejos de adormecer su conciencia, le impelen a una militia, a una ascesis permanente, púdicamente oculta detrás de la alegoría.

Se mueve con soltura en la selección del sustantivo y el adjetivo más oportuno en la frase sencilla, castiza, de construcción elemental. Comienza este poemario con fuerza desde el primer poema, desde el primer verso:

$$
\begin{aligned}
& \text { Mediado ya el camino de la vida } \\
& \text { la selva se hace densa, va perdiendo } \\
& \text { su alegre levedad, retira todas } \\
& \text { las promesas antiguas y nos niega } \\
& \text { también la vuelta atrás. Entonces muchas } \\
& \text { preguntas sin respuesta van formando } \\
& \text { el rostro del crepúsculo, la tarde (p. 9). }
\end{aligned}
$$

El lector advierte el calco intencional del primer verso de la divina Commedia, Nel mezzo del cammin di nostra vita, ${ }^{16}$. Desde este momento es fácil entrever el asunto del libro que comienza.

En efecto, el autor, próximo a cumplir sus cincuenta años, se ve caminado per una selva oscura, una selva selvaggia e aspra e forte ${ }^{17}$, y se propone subir la montaña que se abre ante él - no ya guiado por Virgilio, sino por aquel a quien el mantuano condujo-, por un camino que serpea entre un bosque (purgatorio) que ora se espesa
${ }^{15}$ Cfr. Jorge Manrique, Coplas por la muerte de su padre, XXXV, supra.
${ }^{16}$ Dante, Inferno, I, 1 .

${ }^{17} \mathrm{Ibid}, \mathrm{vv} .2$ y 5.
SUÑÉN, J. C., «La expresión de un deber desconocido (Poesía y conciencia en Blues castellano)» en AAVV, Antonio Gamoneda, Madrid, Calambur, 1993, pp. 95102.

VALENTE, J. Á., Obra poética, 1999, 2 Vols., Madrid, Alianza, Vol 1, 2ª reimpresión, 2000; Vol. 2, 3 ${ }^{\mathrm{a}}$ reimpresión, 2001.

VALVERDE, Á., «La travesía del silencio (Pasión de la mirada)» en AAVV, Antonio Gamoneda, Madrid, Calambur, 1993, pp. 103-108.

_. «La poesía de Antonio Gamoneda (una lectura)», Cuadernos Hispanoamericanos, 522 (1993), pp. 134-142.

VILAS, M., «La muerte, y su hermano el miedo: la “edad” de Antonio Gamoneda» en AAVV, Antonio Gamoneda, Madrid, Calambur, 1993, pp. 49-60. 
El estilo de Ballesteros está haciéndose. El poeta experimenta a lo largo del libro. Este lector - yo-, que le había conocido por Recuerda a un bosque, publicado un año antes, se sorprendió desde la primera línea. Interrumpió su lectura y averiguó que el orden de edición era inverso al de su composición: Los primeros avisos es «vino nuevo en odres nuevos». Y el lector volvió entonces a leer con un interés añadido: intentar descubrir cómo se hace un poeta. Los primeros avisos contienen poemas escritos a lo largo de dos años. A través de ellos, el hombre-Manuel escapa de algo, busca otra cosa, se muestra insatisfecho: se está buscando a sí mismo, al tiempo que huye de sí. El poeta-Manuel, también: quiere desprenderse todavía más - ya no acude apenas a las metáforas, no usa rima, no se sirve de licencias literarias... - , pero quiere aprender a escapar de las palabras mágicas, preñadas de prestigio de otros poetas de otros tiempos, a las que aún acude: «Anábasis», «dioses», «Grecia» (p. 14); «París» (p. 15); «Parnaso» (p. 35). Tiene que decidirse por una tendencia artística u otra: ¿Un eclecticismo? Sabemos que la búsqueda de Los primeros avisos, después de unos pocos años iba a dar alcanzar un fruto sazonado en Recuerda a un bosque.

Como los cultivadores de la «poesía pura» de principios de XX, renunciará a hacer literatura de la literatura, y sólo dejará entrever - a veces involuntariamenteel sustrato cultural, el fondo de lecturas. Ese apuntar a un universo cultural, todavía erudito y entre volutas barrocas, lo advertimos en Los primeros avisos desde su poema preliminar (p. 11). El «ofidio» que «repta»y muestra «obsceno, las curvas relucientes», «su gran musculatura [...] que un día acabará por abrazarte», coloca ante una encrucijada al lector, que se pregunta: ¿A dónde apunta ese reptil? ¿A la serpiente bíblica12, o a las sierpes de Virgilio ${ }^{13}$ ? ¿O quizás a los dos contextos? La evocación de Virgilio - de li altri poeti onore e lume ${ }^{14}$ - transporta al lector a la

$$
\begin{aligned}
& { }_{12} \text { Por ejemplo, Génesis, } 3 . \\
& { }^{13} \text { Cfr. Eneida, canto II, vv. } 199 \text { y ss. } \\
& { }^{14} \text { Dante, Inferno, 1, 82. }
\end{aligned}
$$


El arranque de esta tercera parte es pesimista: «Tu nombre, / igual que nuestros nombres, no estará / nunca en los manuales» (p. 36); pero luchador: «tercos, / siempre incapaces de callar / [...] ya comenzamos a ensayar un ritmo / al que poner palabras» (p. 37). Una inflexión se produce tan pronto como invoca a su mujer, («Para María», p. 39). A partir de ese momento se anuncia un nuevo mundo nocional y espiritual: la lucha diligente por la conquista del yo en la perspectiva de aquella otra vida que termina en la gloria celeste. En este reencuentro con María, aparece en germen el nuevo libro, Recuerda a un bosque: se trata del único poema que se estructura en la misma forma que lo harán todos los del libro siguiente: la estrofa de siete endecasílabos libres. En estos siete versos, cumple llorar con arrepentimiento, reconocer compungido el pasado error: «Con tantos ojos, sí, y, al fin, tan ciego» (p. 39). A partir de ahora comienza un renovado caminar; ahora sí, tras lo auténticamente verdadero, bello y bueno.

A vino nuevo, odres nuevos: «Y es hora de frenar, de andar despacio, / de dar con otro estilo» (p. 45). A un mundo nuevo, a una forma nueva, se ha de ir por un camino estrecho, por un despojarse de adornos y de glorias prestadas (la erudición explícita). El nuevo universo se presenta iluminado por el Dios creador y providente, principio y término de la vida humana (la tercera vida):

$$
\begin{aligned}
& \text { Sólo Tú me conoces. Cuando hayan } \\
& \text { pasado muchos años y no quede } \\
& \text { ningún rastro de mí, cuando el olvido } \\
& \text { se haya apoderado de mis cosas, } \\
& \text { y nadie pueda recordar el eco } \\
& \text { de mis palabras, ni mi rostro, Tú } \\
& \text { me mantendrás intacto en Tu memoria, } \\
& \text { todavía más vivo, conquistado, } \\
& \text { hecho más realidad, reconocido (p. 47). }
\end{aligned}
$$

$Y$ en este renacer a un nuevo referente, a una nueva poesía, a una nueva motivación de la vida, el poeta experimenta la alegría de despertar y -así acaba el poemario - «abriendo los ojos, comprobar / que es todo realidad. No hay nada que sea un / sueño» $(p, 53)$.

FIDEL SEBASTIÁN MEDIAVILLA

Universitat Autònoma de Barcelona

El poeta Manuel Ballesteros (León, 1954) no ha dicho todavía su última palabra, pero ha dicho ya bastantes como para poder estudiar su obra publicada hasta el momento.

Desde su más temprana juventud le acompaña siempre un lápiz afilado que saca en cualquier parte para tomar nota de una impresión, una idea, un sentimiento que más tarde, en casa, intentará desarrollar y componer en verso.

"Recibido: 05-11-2008 Aceptado: 13-01-2009 
En los años 70 promovió en León, con otros escritores, el grupo y revista Yeldo ${ }^{1}, \mathrm{y}$ los premios de poesía «Diario de León». Su primer libro de poesías lleva el título Invitación al viaje (1995), al que siguieron El amanecer de la alabanza (1996), Recuerda a un bosque (2001), Los primeros avisos (2002) y Las casas abandonadas (2003). Está próximo a aparecer un nuevo libro de poemas, Al otro lado, en proceso de edición ${ }^{2}$.

El profesor José Enrique Martínez, en su enciclopedia de la poesía leonesa de 1900 a nuestros días ${ }^{3}$, encuadra a Ballesteros dentro del grupo de poetas de las últimas y penúltimas promociones caracterizados por una mirada existencial y simbólico-trascendente, junto con Pilar Blanco Díaz, José Luis Puerto, María Fernanda Santiago Bolaños, José Manuel Gutiérrez, Adolfo Ares y Tomás Sánchez Santiago ${ }^{4}$.

Según el mismo estudioso, la poesía realista y de la experiencia ha ido, en los últimos años, derivando en España «hacia un desarrollo reflexivo que evita la anécdota o la usa como punto de partida hacia la meditación sobre las grandes verdades del hombre» ${ }^{5}$. Este es el ámbito y la poética en que se mueve la lírica de nuestro autor, que Martínez califica 'órfica'6. La voz de sus primeras obras, según el

${ }^{1}$ Formaron parte del grupo, además de Ballesteros, Vicente Presa, Angel Benavente, Agustín Tuñón y el pintor José María Ampudia, que ilustró los dos números que llegaron a salir (1973 y 1974), el último de los cuales configurado como homenaje a Vicente Aleixandre. Se declaraban críticos con panorama poético del momento, por la mezcla de tendencias que se daban, y llegaban a añorar la

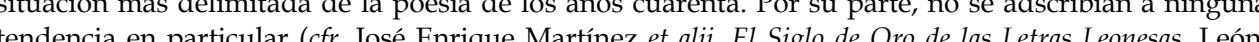
tendencia en particular (cfr. José Enrique Martinez et alli, El Siglo de Or, die las Letrus Leonesas, León Edilesa, 2007, p. 98)

La referencia bibliográfica completa de las obras mencionadas es la que sigue: Invitación al viaje, Madrid, Devenir, 1995; El amanecer de la alabanza, Gijón, Premio Ateneo Jovellanos, 1996; Recuerda a un bosque, Barcelona, Seuba, 2201; Los primeros avisos, Madrid, Devenir, 2002; Las casas abandonadas, Sevilla, Algaida, 2003

Es el autor del apartado dedicado a la poesía en el mencionado volumen colectivo El Siglo de Oro de las Letras Leonesas (pp. 10-131)

${ }^{4}$ Ibid., pp. 117-120.

5 Ibid., p. 117.

«Esta poética órfica o de la plenitud parte de Claudio Rodríguez y Antonio Colinas principalmente. En realidad es una de las bifurcaciones de la tradición simbolista, a través de Rilke, el poeta que escogió la tradición romántica y la herencia simbolista para darles una dimensión trascendente y

\author{
Amor aconsonantado, \\ sufrimiento en asonante \\ la muerte siempre brillante \\ final para lo narrado. \\ Nostalgia: todo el pasado \\ al servicio del poema. \\ Sólo combustible, tema \\ la vida para el cantor \\ que escribe y escribe por \\ salvar la piel de la quema (p. 29).
}

Luego, al poeta:
No creas que tu suerte será otra
después de esta elección, este camino de componer palabras memorables
[...]
Todos te olvidarán y aunque ocurriera
que nadie te olvidase habrías muerto (p. vv. 1-3, 9-10),

al libro (p. 32), a la fama (p. 34). No son odas. Son más bien elegías, marcadas por la nostalgia de un ayer que atrae, y del horror de otro ayer que aún duele. A la vez, se comparte con el autor, en estos poemas, el temor a la recaída en la miseria personal, y el deseo irrefrenable de volver al origen (la innominada y omnipresente isla de Ítaca). De este modo se llega a la antesala de la fama con un rictus de ironía, de desencanto:

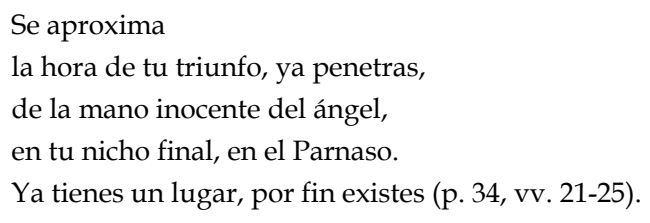

La tercera y última parte del libro se centra en el final del camino, la muerte ( $\mathrm{p}$. 36 y ss.). Los últimos poemas se mueven en el clima habitual de nostalgia y melancolía. Tras la muerte del cuerpo, ¿cuánto tiempo durará la vida en la fama?

${ }^{11}$ La segunda y última composición rimada será un soneto, variación sobre otro de Miguel D’Ors, p 
aficionado, cuando vivía y la disfrutaba, pocos poetas la consiguen después de incinerados ${ }^{9}$.

El autor conoce, sin embargo, una tercera vida que la antigüedad clásica olvidaba o tenía reservada para los pocos inmortales.

La perspectiva y el incentivo de la segunda vida del alma (en la fama) y una tercera y eterna (en el cielo), ha sido versificada en el más bello y conocido poema de la literatura española, la elegía de Jorge Manrique a la muerte de su padre:

$$
\begin{aligned}
& \text { No se os haga tan amarga } \\
& \text { la batalla temerosa } \\
& \text { que esperáis, } \\
& \text { pues otra vida más larga } \\
& \text { de la fama tan gloriosa } \\
& \text { acá dejáis; } \\
& \text { aunque esta vida de honor } \\
& \text { tampoco no es eternal } \\
& \text { ni duradera, } \\
& \text { mas con todo es muy mejor } \\
& \text { que la otra temporal, } \\
& \text { perecedera. }{ }^{10}
\end{aligned}
$$

La consideración trascendente del camino - la vida en los tres niveles - se patentiza desde el poema dedicado a Víctor Botas:

$$
\begin{aligned}
& \text { pasado } \\
& \text { el tiempo, cuando nadie ya recuerde } \\
& \text { ni mis poemas ni mi nombre, entonces, } \\
& \text { [...] yo seguiré existiendo (p. 28). }
\end{aligned}
$$

Primero, el vivir futuro en la fama. Es el momento de cantar a la poesía con una primera $-\mathrm{y}$ prácticamente única ${ }^{11}$ - estrofa canónica, precisamente una décima «Amor aconsonantado»:

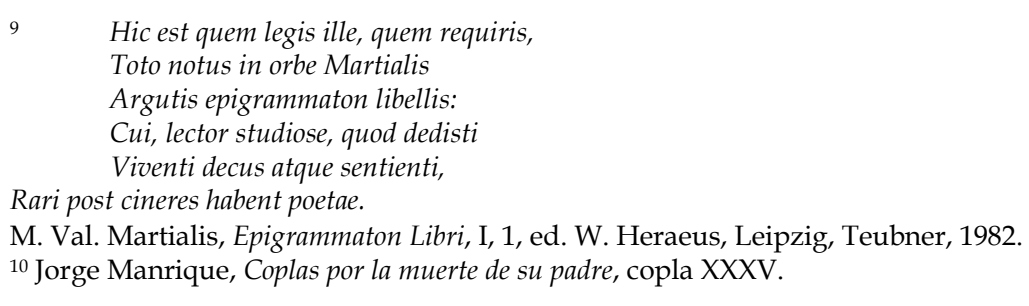

profesor leonés, es «una voz reflexiva y conceptual, intelectualizada, indagadora de esencias, camino de la abstracción, en poemas consecuentemente condensados, cercanos a la "poética de silencio"». Más adelante, «la voz, siempre pulcra rítmicamente, fue haciéndose más cálida y cercana en los poemarios últimos, cuyos núcleos temáticos son la soledad existencial, el sentido de la vida, el tiempo y la muerte» 7 . De estas últimas obras nos vamos a ocupar en las líneas que siguen.

Los autores recientes y contemporáneos que más han influido en su poesía, cuyas trazas aparecen entre líneas - a veces explícitamente mencionados-, son Antonio Machado, Dámaso Alonso, Leopoldo Panero, José María Valverde, Antonio Colinas, Carlos Pujol, Juan Luis Panero, Víctor Botas y Miguel d'Ors.

Es mi propósito analizar en estas páginas la obra de madurez de Ballesteros, a través de sus tres últimos títulos, hasta el momento: Los primeros avisos, aunque publicado después, fue escrito con anterioridad a Recuerda a un bosque, por lo que le daremos preferencia. Tres libros con tres temas unitarios en que se confunden al menos dos planos: el exterior y el íntimo, que se dan la mano. En Los primeros avisos, el viaje y la vida en su hacerse; en Recuerda a un bosque, del bosque al jardín, y de la naturaleza a la cultura, al cultivo de sí; en Las casas abandonadas, las mansiones desiertas y el abandono del cuerpo tras la muerte.

Mensaje y técnica. Voces y conceptos. Ascesis personal y estilística llevada a cabo con esfuerzo y al través de los años y de las hojas escritas y corregidas y vueltas a escribir.

ntregarlas al siglo XX; la otra bifurcación se acoge a una línea mallarmeana y propende a expresa estados no de plenitud, sino de carencia o de precariedad: son las poéticas prometeicas que encabeza entre nosotros, Antonio Gamoneda». Ibid., p. 118

${ }^{7} \mathrm{Ibid}, \mathrm{pp} .117-118$

LECTURA Y SIGNO, 4 (2009), pp. 273-291 


\section{VINUM NOVUM IN UTRES NOVOS O LA BUSCA DEL ESTILO}

Sepa de antemano el lector de la obra de Manuel Ballesteros, que Los primeros avisos, publicado en 2002, después de Recuerda a un bosque (2001), fue compuesto antes que él y contiene - en principio, secuenciadamente- los frutos de una esforzada y tenaz transformación por vía de simplificación.

Hasta cierto punto miscelánea de asuntos varios y formas varias 8 , el texto mantiene la unidad que le proporciona su filiación al autor que, en su devenir, permanece uno y el mismo. De un modo u otro, a lo largo de todo el libro actúa la tensión del viaje, del viaje de la vida: la vida como viaje.

Ballesteros hace siempre autobiografía: honesta, oculta detrás de los diversos recursos de que se vale el pudor. Su poesía es en cierto modo narrativa. Narra la vida del hombre sobre la tierra, la vida de todos los hombres, la vida más íntima del autor.

El iter vitae es tópico antiguo y siempre fecundo. Un referente cultural concreto va a ser en este libro, el viaje de Ulises, el odós homérico, la Odisea.

Esta intención de recorrer junto al lector el camino de su vida se hace explícita desde el segundo verso de la presentación:

$$
\begin{aligned}
& \text { Como un ofidio en lo que escribes repta } \\
& \text { el tema del viaje, sigiloso, } \\
& \text { mudándose de piel, mostrando, obsceno, } \\
& \text { las curvas relucientes, ese brillo, } \\
& \text { su gran musculatura, la potencia } \\
& \text { que un día acabará por abrazarte. }
\end{aligned}
$$

Y la confirma el título del primer poema, «Invitación al viaje».

\begin{abstract}
${ }^{8}$ La versificación se estructura en estrofas de longitud indeterminada. No hay rima. Se mima la métrica. Preferentemente endecasílabos, los versos son en otras ocasiones octosílabos o alejandrinos. Tienen en común estos metros el pertenecer a la más pura tradición del castellano, por ser muy adecuados al temperamento español: el octosílabo del pueblo, el octosílabo del romancero; el endecasílabo italiano que españolizó Garcilaso; el alejandrino, en fin, del antiguo mester de clerecía. La excepción a los versos libres del libro son dos poemas rimados: una décima y un soneto (vid. infra, nota 11).
\end{abstract}

La primera sospecha de que Homero está latente en este discurrir, se corrobora pronto con el poema «Perplejidades del viajero», con una evocación de la industriosa esposa de Ulises:

$$
\begin{aligned}
& \text { Tejerse y destejerse de tu alma } \\
& \text { que te invita a viajar, } \\
& \text { te lleva a ir y venir (p. 19, vv. 5-7). }
\end{aligned}
$$

Otro título, «El Náufrago» (p. 21), acaba de perfilar el modelo de viaje en que se espeja el poeta.

El caminar-navegar invita a considerar la meta. Ballesteros considera la muerte - la suya-, con ánimo realista, valiente y esperanzado: será la hora de la verdad. Solo - nadie ni nada, salvo sus obras, le acompañan - , solo ante Dios:

$$
\begin{aligned}
& \text { No te despedirán como soñaste. } \\
& \text { Tus amigos, tus hijos, tus hermanos, } \\
& \text { las figuras de antaño, el mundo todo } \\
& \text { en que creíste vivir, la luz, el aire, } \\
& \text { habrán desaparecido cuando haya } \\
& \text { que pronunciar tu adiós. Y estarás solo. } \\
& \text { No te despedirán: serás recibido (p. 26). }
\end{aligned}
$$

Una segunda parte del libro, sin perder el hilo del iter vitae, se construye en torno a otro tópico literario de antigua progenie, la supervivencia a través de la fama Ballesteros hace hablar a los libros para que ellos den testimonio:

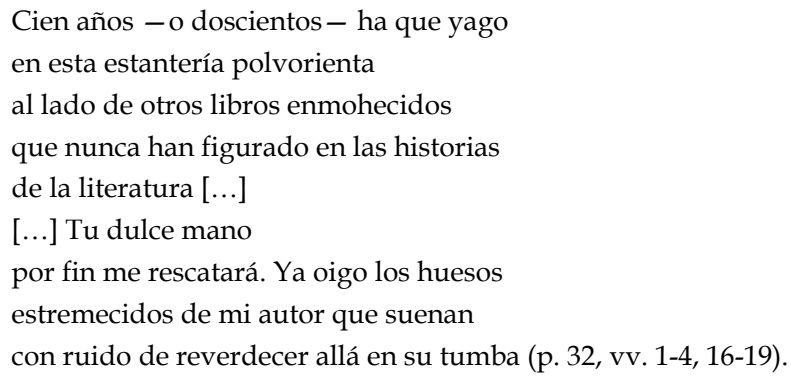

No todos lo consiguen. Marcial bilbilitano lo decía de forma muy parecida en el siglo I:

He aquí a quien lees, a quien buscas, a ese famoso Marcial conocido en todo el mundo por sus picantes libritos de epigramas: la gloria que le diste, lector 
En composiciones como "El hombre olvidado" o "Una mujer acude a la oficina", encontramos una clara temática urbana muy visible en las referencias al escenario en el que se mueve la vida del hombre. Esa ciudad es vista como espacio antagónico de encuentro y desencuentro, aunque, en el fondo, casi siempre predomine cierta imagen amable, cómplice, que pretende alejarla de aquella configuración finisecular de espacio propicio para el hacinamiento o la alienación. También esta visión encierra una ironía canalizada a través del humor, el pastiche, la parodia o, tal vez, la alusión a la música popular moderna en ese último poema citado, así como en "El hombre que aprende a volar" $\mathrm{o}$, tal vez, en "Una mujer que vivía en el bello noroeste".

Pese a lo dicho hasta ahora, ya lo hemos apuntado al comienzo, se encuentran en el poemario ciertas diferencias con la poesía de la experiencia que representarían la línea más personal de Raquel Lanseros. Tal vez predomina en su obra una mirada más colectiva si cabe, mostrada gracias a esa fragmentación del yo en muchos personajes con entidad absolutamente propia. También una indagación más honda en la condición psíquica del hombre, al superar los análisis superficiales y el excesivo distanciamiento irónico a favor de una compenetración o identificación con los personajes creados o recreados. Es destacable además una huida consciente de la métrica tradicional y del versolibrismo (reinvidicados ambos explícita o implícitamente por los experienciales) a favor, sobre todo, del verso libre amétrico, que la alejaría del sesgo clasicista de muchos poetas de aquella tendencia, obteniendo con ello resultados líricos mucho más radicales, pues es el ritmo de la frase o de la palabra el que se impone sobre el ritmo del verso. Pero, también es preciso hacerlo constar, la esmerada elaboración del texto huye de toda improvisación, de toda espontaneidad fácil y poco adecuada.

Por último, aunque la obra de Raquel Lanseros pueda coincidir con la de muchos de los poetas de la experiencia en la búsqueda de esa pretensión de normalidad, en ese tono que dota de sentido común sus apreciaciones y conclusiones y que resulta ajeno a la margi- oración» $(43,23)$, «Aquella casa» $(45,16)$, «La casa en que viviste» $(46,14)$, «Casas abandonadas» $(49,1)$.

Pero el lector quiere conocer el mensaje conceptual. ¿Quién es quién? ¡Cuál es la historia y cuál el mensaje, cuáles la «conseja» y el «consejo» ${ }^{24}$. Como bien dijo en prosa un poeta, es preciso leer despacio ${ }^{25}$, y otro de los grandes advertía la importancia de volver sobre lo ya leído; que en cuestión de poesía, quien no relee no lee ${ }^{26}$. Como en las viejas traducciones escolares de Latín, a este lector -a mí- le ha sido preciso ir averiguando en cada poema - como si se tratase de una larga frase de Cicerón - dónde está el Sujeto, por así decir.

El lector de Ballesteros ya sabe por los libros precedentes, que el autor es pudoroso; que se resiste a airear lo más íntimo de lo suyo y de los suyos; que diluye a veces el yo detrás de un tú o de un impersonal. No es fácil averiguar qué persona real responde al yo o al tú gramatical. En Las casas abandonadas no engaña, pero se oculta y se reserva para el lector realmente interesado, para quien quiere saber más y con más seguridad. Parece que el poemario se desarrolla en los siguientes términos:

El poeta ofrece su voz («permite que te preste mi voz», p. 9) a una persona muy familiar («Tú me tienes a mí», ibid.) que no espera «más que la hora de morir» (ibid.). Esta persona es una mujer («sonámbula», p. 16; «soy yo Fulana», p. 31), hermana del poeta («Para mi madre», p. 30), asume la realidad de que va a «morir siendo joven» a causa de un «cáncer», y dejar «dos hijos huérfanos» (p. 23). En los tres poemas que siguen al primero (pp. 10-13) habla un genérico nosotros detrás del que tanto se puede ver la persona del autor, la del tú o la del mundo en general: son reflexiones didáctico-morales acerca de «la realidad» en la perspectiva de la muerte

${ }^{24}$ Cfr. Mateo Alemán, Guzmán de Alfarache, «Del mismo al discreto lector».

${ }^{25}$ Así decía Jorge Salinas: «No sería pertinente alegar aquí mi propio caso; pero en los de muchos de mis amigos de alta marca intelectual, es cosa confesada que con el más y más leer se aprende a leer más despacio, no más a la carrera, y se disfruta de esa lentitud, por las delicias que deja» (Pedro Salinas, «Defensa de la lectura», El defensor, Madrid, Alianza, 1986, p. 133).

${ }^{26}$ Cfr. Jorge Guillen, Lenguaje y poesía, Madrid, Alianza, 1972, p, 70.

LECTURA Y SIGNO, 4 (2009), pp. 273-29 
(10), del «camino» que queda por recorrer (11), del esfuerzo felizmente consumado (12). A partir de aquí, es el tú, la hermana desahuciada, quien reflexiona en primera persona, con algunas salvedades, como son, precisamente los dos poemas inmediatos (pp. 14 y 15) en que de modo impersonal se formulan nuevos apotegmas.

En dos ocasiones toma la palabra el autor ('yo' es yo) para dirigirse, en la mitad del libro, a la cara consorte - el tú de estos versos-, al calor del hogar conyugal (p. 25), a la intimidad del lecho común (p. 26). Por un momento el poeta se toma un respiro y habla desde el tiempo real, en que escribe, que no es el mismo tiempo - pasado - sobre el que escribe. El primero dice así:

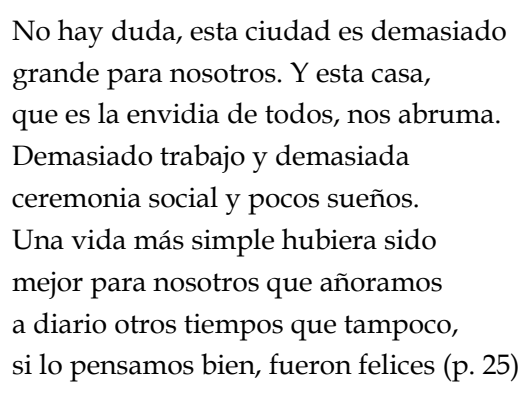

En los más de los poemas, el poeta presta su voz a la sufriente para que hable en voz alta. En otros, ella habla consigo misma, conjugando el yo y el tú en soliloquio (pp. 20, 40, 43, 46), y, acercándose al fin del poemario -y de su camino-, ésta se dirige al Tú de Dios, ya en la figura de padre del «hijo pródigo» que es ella (p. 37), ya en la del Maestro resucitado que espera desde la orilla la llegada de la pesca milagrosa (p. 39).

El poeta, narrador invisible, omnisciente, aborda el último poema conclusivo - para describir una casa abandonada, la vieja casa de sus padres rememorada amorosamente en los versos precedentes, pp. 43-48: el jardín, el despacho, la iglesia contigua, el pueblo. $Y$ permite adivinar, a quien se esfuerza en comprender, que «la casa» es el cuerpo de los hombres, lo que se queda aquí, lo corruptible. Las «casas abandonadas» son los cuerpos de los muertos, las vidas cierta universalidad sobre la vida, sobre los sentimientos, sobre la propia conciencia moral, una reflexión que pueda serle de utilidad, aunque no le aporte la seguridad anhelada, porque, al cabo, hay que plantarle cara a la vida pues, sin duda alguna, "la vida va en serio", nos dirá en "Un joven poeta recuerda a su padre".

En algunas composiciones como "La mujer herida", "El hombre casado", "Una mujer enferma", "Una mujer insoportablemente leve" o "El hombre desnudo", entre otras, se impone una más amplia presencia del autobiografismo, entendido éste como sutil artificio literario. En ellas, a través de la utilización de una primera persona que, como sucede en los otros poemas, no necesariamente deberemos identificar con la autora, y que se combina con la segunda o, incluso, con la tercera, percibimos esa clara disposición, aparentemente confesional, que le permite analizar su propia sustancia vital, recrearla literariamente ficcionalizada. Participa así de eso que José Carlos Mainer ha denominado "topografía borrosa" del yo. La poeta se muestra, pessoanamente, como fingido- ra, una fingidora que, tal vez, se confiesa a los ojos del lector, pero adoptando siempre ese sentido teatral, ese distanciamiento brechtiano profundamente literario que suele exigir toda creación artística. Hay en estos textos un mayor acendramiento de lo individual, pero a través de un intimismo canalizado, como en las otras composiciones, mediante la técnica objetivadora del monólogo dramático buscando así la huida de confesionalismo romántico, que aún hoy colea, hacia la elaboración de un artificio sabiamente meditado y contenido. Esa ficcionalización del sujeto combinada con el uso de diferentes máscaras para cada composición supone una clara diferenciación entre el yo empírico de la poeta y su recreación a través del yo lírico. Se busca con ello desacralizar su intimidad a través de la mirada externa que supone la máscara, en algunos casos, o la visión exterior del personaje en otros a través de un "yo" que no es sino un mero artificio verbal de tintes, tal vez, posmodernos, como también sucede a menudo en la poesía de la experiencia. 
por otra parte, resultan, a través de la construcción poemática, objetivadas, puestas ante el lector para seducirlo o persuadirlo, como ya dijimos, a través de ese simulacro de verosimilitud, procurando, al mismo tiempo, un lugar de encuentro entre el lector y la poeta. De este modo, en este terreno ficticio creado en el poemario, ambos comparten reflexiones, lecturas o, incluso, tratan de ir más allá a través de la identificación con escritores o con personajes mitológicos o literarios cuya capacidad de seducción a través del arte se plantea como vía de realización personal. Así, se insinúa en “La mujer sin nombre [o Eurídice revisitada]", cuando la voz poética asevera: “será que sólo tengo / un jardín de palabras unidas a un puñado de buenas intenciones. // Y ganas frustradas de haber nacido Orfeo".

La reivindicación de la experiencia y de la emoción de las que el lector puede abstraer otras ideas, otras experiencias, está también muy presente. Con la conciencia, eso sí, de la diferenciación clara entre la realidad y su representación poemática como "simulacro de experiencia real", que diría Gil de Biedma.
Las experiencias de cada uno de los personajes recreados por Lanseros se proponen por la poeta como motivos de reflexión, como ejemplos certeros acerca de lo precario de una existencia en tanto que ésta no ofrece ningún tipo de certidumbre de absoluto una vez caídos los viejos dogmas del pasado. Como el ser humano real, también ellos pueden verse, en muchos casos, como seres perdidos, desnortados, que anhelan alguna certeza a la que aferrarse, alguna solidez y salvación que dén sentido a sus vidas desorientadas. Salvación que, a veces (y ello se propone como idea al lector), se halla en la misma literatura, en La insoportable levedad del ser, de Kundera, o en los versos de Walt Whitman, pues “Las sombras de los árboles / se parecen a los versos de Whitman / porque siguen creciendo eternamente". De este modo, la vida se sustentaría también en esas vivencias propias o vicarias, en esos fugaces instantes que la constituyen y que, con suma precisión, la poeta va exponiendo de modo preciso en cada uno de sus textos. Así, a partir de ese terreno compartible con la autora, el lector deberá obtener un motivo de reflexión de pasadas... Pero esos cuerpos, lo mismo que esas casas llenas de recuerdos, se miran con un cariño que no se puede extinguir, porque ellos serán un día transformados para ser compañeros eternos, en la morada eterna. A esa casa abandonada queremos siempre volver, como quieren volver los hombres enamorados a visitar en sus tumbas los restos de sus difuntos.

Las casas abandonadas no es propiamente una elegía, por cuanto no discurre tanto sobre los sentimientos y lecciones de una muerte consumada, cuanto de una muerte que se anuncia próxima e inexorable. Delante de ella el hombre se cuestiona su vida pasada y emprende un camino de rectificación, de vuelta a la religión con las disposiciones del «hijo pródigo», con la esperanza de encontrar en la muerte la vida. Se dejará la casa, el cuerpo corruptible - ca-ro da-ta ver-mibus, ya - para entrar en la mansión permanente (non enim habemus hic manentem civitatem, sed futuram inquirimus ${ }^{27}$ ).

Pienso que el clima de expectación de la muerte en compañía, a la vez con esperanza, con compasión y con esa especie de sentimiento tan humano ante el salto a lo desconocido se expresa se capta perfectamente en el poema dedicado «Para mi madre, in memoriam»:

$$
\begin{aligned}
& \text { Supongo que sabré que ha llegado } \\
& \text { la hora de morir por algún signo } \\
& \text { que me harán sólo a mí. Como la nieve } \\
& \text { que aquella madrugada iluminó } \\
& \text { en tu ventana el páramo y nos hizo } \\
& \text { saber a ti y a mí que esa mañana, } \\
& \text { esa misma mañana, partirías. }
\end{aligned}
$$

Recuerda a un bosque nos invita a hacer una meditación de la muerte. Que, como decía Gracián, «es preciso meditarla muchas veces antes, para acertarla hacer bien una sola después» 28 .

\footnotetext{
27 Ad Hebraeos, $13,14$.

${ }^{28}$ Baltasar Gracian, El discreto, XXV, in fine
} 
tonalidad casi conversacional que rechaza toda grandilocuencia e impostación y se centra en la búsqueda en un amplio grado de lo que podríamos denominar "verosimilitud poética". No hay facilidad en la composición, sino una sencillez arduamente elaborada que pretende persuadir al lector, tratando, al mismo tiempo, de involucrarlo en el texto, como si de una obra narrativa se tratase.

Por ello, no es extraño encontrar en estas composiciones una marcada progresión argumental propia del género narrativo, pues todos los poemas se muestran como pequeños relatos, pequeñas historias de seres desvalidos en ocasiones o que, en otras, emergen del fondo de una experiencia dolorosa transmutados, maduros, rehechos como en "La mujer herida", marcada por "serenas cicatrices sobre viejas heridas". En algunos casos concretos la narratividad del poema se perfila a través de una clara estructuración de la anécdota con alusiones al pasado y al presente del personaje para comprender su evolución (“Un joven poeta recuerda a su padre”, “Una mujer vivía en el bello noroeste"), para recordarnos el paso inmisericorde del tiempo y la importancia de la memoria frágil ("El hombre olvidado"), para mostrar, desde el pasado, el presente como un mundo, que siendo entonces futuro, albergaba un anhelo de esperanza que resultará no siempre realizada, no siempre alcanzada, como sucede en "Un hombre cree identificar...", "La mina más linda" o en la hermosa composición que cierra el poemario, "Beatriz Orieta". Concretamente en ésta, ese deseo de un futuro promisorio se trunca con la muerte de la protagonista aunque, de fondo, pervive el latido de una esperanza cifrada en un porvenir en el que la muerte, $y$ su incierto destino, pueda unir a los dos amantes para la eternidad, pues "la muerte / vuelve a acercar los labios / de los que un día se amaron".

En el fondo, esta narratividad esconde, como en los poetas experienciales, una visión de la poesía entendida como género de ficción, así como una visión de la literatura como juego, como artificio artístico, sin que por ello la poesía de Raquel Lanseros renuncie, al mismo tiempo, a una sinceridad que pudiera ser reveladora de las inquietudes de su yo personal. Inquietudes que, 
Los ojos de la niebla es un poemario breve, integrado por diecinueve composiciones en las que la poeta, a través de la técnica del monólogo dramático, se desdobla por lo menos en otras tantas voces, en diferentes personajes poemáticos para, a través del distanciamiento que propone este artificio, hablarnos de algunas de las preocupaciones fundamentales presentes en su poesía: la reflexión sobre la vida, la conciencia de la pérdida y los fracasos, la renuncia, el olvido, el paso del tiempo, el valor de los sueños... Todo ello sin renegar de un cierto vitalismo característico de otros textos de la autora que se percibe en grado sumo en composiciones de este libro como "El hombre que brillaba como un ángel".

Es cierto que algunas de las características, tanto temáticas como formales, de Los ojos de la niebla, podrían servir para incluir este libro y a su autora en esa corriente, que viene dando sus ya últimos coletazos, llamada "poesía de la experiencia". Sin duda, la precisión en las imágenes y en el lenguaje de que hace gala, la visión de la poesía como artificio artístico, la importancia de la experiencia o de un cierto autobiografismo, del humor, de un marcado tono elegíaco en algunas composiciones, así como de la temática urbana tan cara a estos poetas, inclinarían la balanza en este sentido. Estaríamos, pues, hablando de un ejemplo claro de epigonismo con respecto a los poetas experienciales. Sin embargo, no sólo se deberían cargar las tintas en ese sentido, pues es preciso aclarar que, en el caso de Raquel Lanseros, hay algo más.

La precisión lingüística aludida se muestra en el uso de un lenguaje coloquial que no rehúye el prosaísmo, un lenguaje que busca acercarse al lector a través de una elaborada selección del léxico cotidiano y que está presente ya desde la primera composición (“Un joven poeta recuerda a su padre") en la que además, a nivel de contenido, se nos habla de lo "obvio", el "vivir cotidiano", "la fiesta de las cosas sencillas". En este poema, que junto al que cierra el libro marcan el tono, un tanto elegíaco como ya hemos apuntado, de todo el conjunto, la autora opta a menudo por una inteligibilidad de la imagen, una narratividad estudiada, una sobriedad y una marcada 
RAQUEL LANSEROS, LOS OJOS DE LA NIEBLA, MADRID, VISOR, 2008, 48 PP.

MARIO PAZ GONZÁLEZ

INSTITUTO LOS LLANOS. CAMARZANA DE TERA. ZAMORA

El trayecto poético de Raquel Lanseros (Jerez de la Frontera, 1973) se ha ido afianzando con una rapidez poco usual. Sus dos libros anteriores (Leyendas del promontorio, de 2005, y Diario de un destello, de 2006) daban fe de una voz poética rica en matices, con unos rasgos de madurez bien perfilados y una solidez compositiva carente de titubeos. Podríamos hablar de un proyecto poéti- co firme que, tras el accésit del Adonais por el último de los libros citado, viene a apuntalar el presente título, Los ojos de la niebla (2008), galardonado con el XXI Premio Unicaja de Poesía por un jurado compuesto por José Manuel Caballero Bonald, Felipe Benítez Reyes, Luis García Montero, Manuel Alcántara, Alfonso Canales y Jesús García Sánchez. 
ELENA VEGA SAMPAYO, LA POESÍA ESENCIAL DE JOSÉ CORREDOR-MATHEOS, LEÓN, UNIVERSIDAD, 2008, 572 PP

JUAN CARLOS MERCHÁN RUIZ IES MERCE RODOREDA

La Universidad de León publica una obra oportuna y necesaria para acercarse de una forma científica y sugerente a la obra poética del Premio Nacional de Poesía 2005 por El don de la ignorancia. Se trata de una nueva tesis doctoral, leída en 2007, que nace bajo la sabia dirección del catedrático don José María Balcells. Para todos aquellos lec- tores y eruditos que hayan seguido el curso de la poesía española de los últimos decenios, el nombre de José Corredor es un sinónimo de calidad y originalidad. Las palabras introductorias de trabajo definen aquello que todo buen conocedor de la poesía española reconoce: «osé Corredor-Matheos hace de su poesía una búsqueda de lo esencial que 
abarca más de cinco décadas de creación. El análisis de su obra poética completa, sin duda la de uno de los más interesantes y valiosos autores de la llamada "promoción del cincuenta" y que se encuentra inexplorada en buena parte salvo por marcadas excepciones, fundamenta la razón de este estudio.»

Esta tesis es de una pertinencia absoluta por lo que de esclarecedor pueda contener hacia una figura poética que, como las palabras citadas señalan, ha sido un epígono de la fértil promoción o generación del cincuenta. Ésta, sin lugar a dudas, ha sido justamente estudiada en lo que respecta a los grandes nombres, pero no así para el resto de poetas que también aportan una obra poética de primer orden, como es el caso de José Corredor-Matheos. Quizá la discreción y humildad que siempre le han caracterizado, puedan ahora contemplarse desde una nueva perspectiva mucho más certera y profunda, pues creemos que, en efecto, este es uno de los logros de este libro. La biografía del poeta es sucinta, como la de tantos grandes poetas. Aunque alberga alguna noticia de la vida del vate, nacido en Alcázar de San Juan, pe- ro naturalizado en tierras catalanas desde su primera infancia. Es revelador que se nos recuerden facetas de José Corredor, como la del atletismo o la de sus conocimientos sobre cerámica. No es casualidad, por ejemplo, que el poeta se haya dedicado al mundo editorial, en el que ha destacado en su faceta de asesor $\mathrm{y}$, sobre todo, su otra vertiente de crítico de arte. Su espíritu creativo le ha llevado a ser un gran conocedor del arte $-\mathrm{y}$ en el presente estudio se tienen en cuenta las conexiones entre poesía y pinturapor lo que, entre otras distinciones, es académico correspondiente de la Real Academia de Bellas Artes de San Fernando. También hay premios de renombre, además del fundamental Premio Nacional de 2005, como el Boscán de poesía de 1961 o el Ciutat de Barcelona 2008 por Un pez que va por el jardín.

En definitiva, una labor continuada, rica y constante que empieza a ser reconocida en su trayectoria, a pesar de que ello no sea crucial para el desarrollo de una obra poética, aunque sí para los estudiosos de la poesía española del siglo veinte o para los degustadores de poesía a secas. El propio poeta lo afir- dar que hay nociones que no han perdido el sentido. Todo está arraigado en una ética y una estética, en un conoci- miento y en una metafísica. A su sombra, en su jardín, crea el poeta. 
dad absoluta en la que no cabe la carencia, la nostalgia, la ausencia. El amor, más allá del tiempo, no conocerá límites. Es el máximo del hombre, y su acceso a la divinidad.

No hay mística, glorificación, sin ascesis, y el poeta mira todo con ojos purificados, con ojos interiores que, lejos de ocultarle la verdadera sacralidad de lo natural, le recuerdan otro destino. Celebra la belleza del mundo y, más allá de los cepos que en su materialidad le tiende, piensa en la trascendencia. No hace, por otra parte, diferenciaciones entre la belleza de la juventud, la de la naturaleza o el gozo del saber. La contemplación conlleva la meditación y la fruición, con la finura propia del intelectual que siente más allá de sí pero dentro de él. Y todo le implica, le enriquece y le da alas. No anclan las cosas a la tierra, invitan al vuelo. Nada es accidental, felizmente, y aquí quiebra la modernidad, pues, en su esencia de manifiesta belleza, todo se salva. El amor y la belleza son consustanciales, se exigen mutuamente, y tendrán su definitivo cumplimiento en la resurrección.
Muchas veces, el poema no surge de una experiencia visual, sino de una lectura o de un apunte libresco. No pocas, aplica lo leído a lo visto, o vivido. Da lo mismo, sacará siempre el mejor partido, y sensación y pensamiento afluirán, en sabio injerto, por el verso siempre claro y armonioso. Hay, en su humanismo, la elegancia de la expresión renacentista. La actualidad, aun en cualquier detalle, es vista bajo el prisma de esa luz armoniosa que tiende a la belleza y a la perennidad, al sentido que les da el artista, el filósofo que las contempla. Léase, por ejemplo, “Doncel con dálmata", en que se resignifica el mito.

Escribe el propio autor de este hermoso libro en su prólogo que un poeta es alguien que dice verdades elementales, o las recuerda. Lo que no dice es que para ello se necesita una sensibilidad muy aguda capaz de fijarse en todo, de contemplarlo con amor y pasarlo por el tamiz de todos cuantos antes, siglos antes, lo miraron también con el amor que engendra la sabiduría y lo dijeron con el resplandor de la belleza. En estos tiempos, un ejercicio de ascesis, de librarse de demasiada hojarasca. Y recor- ma, al autodefinirse como "al margen". El respeto que el poeta siente por la literatura y el arte, y muy especialmente por la labor poética, le han impelido siempre a persistir en la expresión de su voz poética, sin demasiados gestos ni llamadas al tendido mediático. De enorme utilidad es también la organización de la obra corredoriana en etapas, basada en los diferentes tiempos de escritura. Los diez conjuntos poéticos analizados - hasta 2004- se agrupan en una hipótesis de clasificación. Tanto para un lector ajeno a la trayectoria de José Corredor, como para quien desee estudiar su obra, dicha organización puede ser un excelente punto de partida. Elena Vega-Sampayo propone una primera etapa de "Poesía de la vida cotidiana", la de los inicios, por Ocasión donde amarte (1953) y Ahora mismo (1960); la segunda, la "Poesía de la existencia", que englobaría la década de los sesenta, con Poema para un nuevo libro (1962), Libro provisional (1967), Pequeña Anábasis (1962-1964), y La patria que buscábamos (1965-1971); y la última etapa, la "Poesía del despojamiento", por Carta a Li-Po (1975), Y tu poema empieza (1987), Jardín de arena
(1994) y El don de la ignorancia (2004) Pero, como la autora explica, «Los seis primeros libros de Corredor-Matheos aquéllos publicados junto a Carta a Li-Po en el volumen editado por Ángel Crespo en 1981-, podrían ser leídos como un preludio poético. Esta lectura de los poemarios escritos antes de 1970 se encuentra cegada por el esplendor del libro publicado en 1975, que preña de un nuevo significado a posteriori toda la obra anterior a su aparición, incluso la posterior no puede dejar de leerse, sino como heredera de esta luz. Pero sólo hasta la aparición de El don de la ignorancia.»

Es remarcable que el análisis de los diez conjuntos poéticos de Corredor se adentra en una de las claves de su poesía, la de los límites. El espacio se halla en el centro de una reflexión poética de primer orden para Corredor. El anhelo de autoconocimiento, la aceptación de los límites espacio-temporales, se instituyen en esta poesía a lo largo de su trayectoria. Tras el análisis de la trayectoria y las etapas de la poesía corredoriana, Vega realiza una incursión reveladora en la teoría poética, que subtitula "La 
búsqueda de lo esencial". En ella, se recorren los escritos de José Corredor sobre su concepto de poesía y, después, un estudio pormenorizado de los escritos de éste acerca de otros poetas coetáneos. En ocasiones son, además, amigos del poeta, como es el caso de Ángel Crespo o Lorenzo Gomis; otras veces se trata de artículos sobre algunos poetas del 27 (Lorca, Dámaso Alonso, Aleixandre, Alberti). De manifiesto interés son, por ejemplo, los recuerdos de la tertulia madrileña del Café Gijón, en la que destaca la figura de Gerardo Diego. Éste representó para Corredor la primera influencia poderosa de un poeta contemporáneo. Además, tiene de él un recuerdo afectuoso: «Cuando iba a Madrid, por asuntos de Espasa, frecuentaba las tertulias del Café Gijón, presididas en silencio por Gerardo Diego, a quien llegué a apreciar mucho. Era una persona excelente y un gran poeta.»

La primera parte del estudio sobre la obra de José Corredor culmina con dos breves capítulos. Una exposición sobre la faceta de crítico de arte y las posibles conexiones teórico-prácticas entre poesía y pintura, y una breve incursión en las influencias o resonancias de otros poetas. Dejando a un lado los ecos machadianos o juanramonianos, entre otros, descuella, por su relevancia en los textos corredorianos, el apartado dedicado a la mística. La poética del despojamiento y la búsqueda de la esencialidad, que caracterizan esta poesía, tienen una influencia mística profunda. Desde Carta a Li-Po hasta El don de la ignorancia, la mística y la literatura oriental han dejado su influjo evidente en su poesía. Junto al análisis de la mística europea, hay un inevitable acercamiento corredoriano al budismo, al sufismo y al taoísmo. A partir de aquí, el estudio de VegaSampayo se transforma en un aquilatamiento detenido del corpus poético. La autora ha optado por un acercamiento sincrónico a la poesía de Corredor. Primero la métrica, el versolibrismo, el soneto o el haikú, estudiados desde una perspectiva retórica. Tanto el empleo del soneto como el del haikú aportan una información muy pertinente para el acercamiento a las técnicas expresivas del poeta. De igual forma, resulta interesante el análisis del encabalgamiento. Su uso es recurrente en la poesía corredo- la presencia de la persona, su unidad radical. Valga como ejemplo magnífico el poema "Si me despierto en medio de la noche", en el que habla de una realidad no ya sólo que representa la belleza o la bondad - "Siento en tu piel al ser humano bueno" - , sino la verdad definitiva que serán un día los cuerpos del amor, como dice en el que cierra el libro:

"Hay algo en el amor". El amor, esa hilazón, esa comunión con el amado, visto unitariamente en la elocuencia de su cuerpo, llena de sentido la propia existencia, que sólo así halla su lugar en el cosmos, se reconoce y se proyecta como bien más allá de la mera existencia o cómputo temporal, más allá del espacio físico, reconocible, en que los cuerpos se encuentran y se relacionan.

Así la vida física es presentida como desbordamiento de cuanto la sujeta al aquí y al ahora. El poema que abre el libro es programático. Su título, “Exceso de vida", hace del amor una metafísica, una superación de los meros datos de la conciencia:

En mi vida no cabe este exceso de vida Mejor, si te dijera que medito las cosas (fronteras y distancias) en los términos propios de la resurrección, cuando nos alzaremos sobre las coordenadas del tiempo y del espacio,

independientemente del mar que nos

separa.

Sueño con el momento perfecto del abrazo $\sin$ prisa, de los besos que quedaron $\sin$ darse.

Sueño con que tu cuerpo vive junto a mi cuerpo

y espero la mañana en la que no habrá límites.

El cuerpo del amor es un tú inmortal, y por ende, el nosotros, los cuerpos resurrectos. El "polvo enamorado" de Quevedo, superado en lo que tiene de dualismo cristiano, es trascendido por una entidad más sublime. Si el amor es más fuerte que la muerte, parece decirnos el poeta, sólo se realizará en plenitud sobrepasando a ésta, no pereciendo en ella. Los griegos primitivos veían al hombre no precisamente como una realidad dual, ni tampoco es esa la representación que de él se hace en la literatura hebrea. Para el antiguo pensamiento hebreo la sexualidad no era solamente la unión de cuerpos, sino el encuentro de las personas, una relación fecunda, pura religiosa. También para este poeta, el amor, la plenitud de la realidad existencial humana, sólo puede concebirse como presencia permanente, como reali- 
tino de todo lo que es humano más allá del milagro de existir sin más. ¿Y qué es lo que no atañe al hombre, si es la medida de todas las cosas?

En esta poesía nada queda reducido, nada parece limitado a la dimensión alicorta y egoísta de la modernidad, sino que se desborda, surte más allá del horizonte mecanicista y estrecho del hombre demediado de nuestros días. Y cuyo mejor ejemplo para ilustrar tal medianía, tal amputación, es la pobreza, el brillo mate a la que se ha reducido el lenguaje que le revela el mundo y que lo revela a él. La palabra, lejos de su diafanidad, oculta y distorsiona, y le esclaviza, en lugar de acrecentarle en su humanidad. Por eso el poeta vuelve a los clásicos, que iluminan la realidad del hoy de otra manera, devolviéndole a la mirada el brillo de la revelación, y así encontrar el aura perdida de las palabras, "las viejas metáforas", que dice en el poema "Contracandela", y "leer el diccionario como un libro de horas". Es decir, el brillo de lo sagrado, que es el de la belleza y el de la verdad, y el del bien.

He aquí la fulguración de esta poesía, porque no renuncia a nada, porque aspira al máximo, y no cree en la limitación ni en el discurso reductor, destructor, del pensamiento que sólo deja cenizas tras de sí. Léase el poema "Felicidad natural". Hay una contemplación jubilosa, afirmativa, de la realidad que se trasciende ante la presencia y el destino del contemplador. $\mathrm{Y}$ tantos otros.

El contemplador, el hablante, el poeta, que siente su palabra encendida por esa fuerza oculta y misteriosa que, como decía Dante, mueve el sol y las estrellas y cuanto existe. Eros es más, y se le supedita el logos. Eros no es una abstracción, sino una apoteosis que se encarna en el cuerpo. Esta poesía es una celebración del cuerpo, pero no meramente del cuerpo físico, en su intensidad sensorial, sino de una realidad más compleja, unitaria, germinal. Trascendente. Hay una mística del cuerpo que echa por tierra las consabidas visiones deformantes o reductoras, tan extendidas, del dualismo platónico, fosilizado en el Cristianismo, por una parte, y del materialismo más grosero, por otra.

“Aristóteles dice: un cuerpo bello / ha de ser percibido en su totalidad". Para el poeta, el cuerpo y sólo el cuerpo es riana y pueden observarse evoluciones estéticas desde este punto de vista formal. Esta segunda parte de la tesis se reanuda con el estudio de nociones trascendentales para la aprehensión de la esencia poética de Corredor-Matheos.

En primer lugar, Vega-Sampayo se ocupa de lo cotidiano. Es un aspecto de la obra corredoriana que afecta principalmente -aunque no exclusivamente - al estadio inicial de su trayectoria, a los primeros conjuntos poéticos, Ocasión donde amarte y Ahora mismo. Y, junto a lo cotidiano, aparece lo social. Es destacable el seguimiento que se hace de este tema en La patria que buscábamos. Asimismo, incluido en este acercamiento temático de lo social, destaca el motivo del vientre, que permite contrastar su uso en otros poetas. Son aproximaciones temáticas a la obra, vectores que iluminan asociaciones y relaciones intrapoéticas. Además de lo cotidiano y lo social, el análisis se completa con un recorrido por el tratamiento del tiempo, la nada, la mirada y la naturaleza. El último capítulo está dedicado a la metapoesía corredoriana. Partiendo de la recurrencia de la metapoesía en la trayectoria de Corredor-Matheos, la autora extrae conclusiones importantes en cuanto a su concepción del verso y del arte poético. Nos llama la atención, por lo reveladora e interesante, la noción del "runruneo metafísico". Concepto que Corredor extrae de Ramón Gaya, otro intelectual catador de arte como el propio CorredorMatheos. Como aclara Vega-Sampayo, lo del "runruneo metafísico" «aunque el autor del libro El sentimiento de la pintura considere el runruneo metafísico como lo primero que percibe el poeta de la realidad, Corredor-Matheos extrema el postulado y considera que ese mismo runruneo, aire o ritmo inicial es ya el poema»". 
JUAN ANTONIO GONZÁLEZ-IGLESIAS, EROS ES MÁS, MADRID, VISOR, 2007, 78 PP. CÉSAR Augusto AYUSO
InSTITUTO ALONSO BERRUGUETE. PALENCIA

Ya en su libro anterior, Un ángulo me basta (2002), el salmantino Juan Antonio González-Iglesias había plantado irrefutablemente su tienda en la actual poesía española. Con Eros es más, la admiración crece. Una referencia deslumbradora por única, por distinta, y por hermosa y profunda. Lo mejor de la tradición cultural de Occidente lo vierte en su verso moderno, igual que lee la heterogénea realidad de hoy a la luz de los maestros de siempre, de modo que, en su mirada, cuanto escribe adquiere la certeza de la perennidad y el temblor del tiempo desmedido, o la desmesura de deslumbramiento que está por llegar. Su poesía no habla de una realidad pasajera, inevitable o contingente, sino del des- 
Como muy bien señala Miró, Juan de Arguijo hizo del soneto "al itálico modo" su bandera poética. No olvida mencionar cuán relevante fue en tal empeño el influjo del gran maestro sevillano, Fernando de Herrera, cuyos cultismos semánticos y una cierta artificiosidad retórica ennoblecerían el verso castellano; un verso ligero y sentido que Arguijo habría leído en Garcilaso.

Por otra parte, explica con claridad que sus sonetos mantienen una estructura fija y sin variantes, según la cual los cuartetos presentan el tema del poema y los tercetos concentran su enseñanza moral. Esta supuesta rigidez, que implicaría, para algunos, un cierto formulismo embellecedor, no impide que Arguijo destaque por la musicalidad de sus estructuras rítmicas y fonéticas, ni tampoco que en su poetizar el adjetivo eleve y mejore, en términos semánticos, la composición. El editor consigue argumentar así que los dioses, los mitos, los triunfos, las caídas, la suerte, el infortunio... se convierten en la pluma de Arguijo en una síntesis formal equilibrada de la cultura humanística y expresan una emoción contenida.
Oriol Miró se enfrentaba al editar este volumen de la Poesía Completa a un reto nada menor: aportar más luz a las ediciones publicadas sobre Juan de Arguijo; las de Stanko B. Vranick (1972, 1985), concebidas ambas, por vez primera, desde criterios estrictamente filológicos, y la de Gaspar Garrote Bernal y Vicente Cristóbal López (2004), un ingente estudio cuyo exhaustivo y valioso volumen de notas críticas poco margen dejaba para cualquier investigador.

Con todo, no ceja en su empeño y edita, a la postre, y esto es lo más relevante, toda la Poesía completa del sevillano. Especial interés merece el apartado que destina a explicar los Testimonios de la poesía arguijiana, testimonios que se dividen en la Rama Medina y la Rama Espinosa.

Oriol Miró edita, en concreto, el manuscrito de la Rama Medina que reposa en la Biblioteca Nacional de Madrid, objeto de un análisis muy pormenorizado que le permite reconstruir la ajetreada historia de los versos arguijianos; una labor muy digna, por complicada y minuciosa, de ser mencionada aquí. nalidad o a lo extraordinario que ésta conlleva, hay una característica fundamental que, a nuestro modo de ver, distancia la obra de esta poeta de aquella tendencia y que, a la luz de sus libros anteriores, parece ser ya una sutil característica de la producción de esta autora, un rasgo propio que se ha ido perfilando con sobriedad. Nos referimos al hecho de que, en su caso, la confesión autobiográfica se muestra (para bien) carente de un humor o ironía demasiado explícitos $y$, tal vez por ello, gastados. Raquel Lanseros no tiene miedo a reconocer una franca postura de optimismo vital que no le impide, sin embargo, ser consciente de que la vida no es fácil para sus criaturas, "la vida", nos dirá en otra composición, "ha sido siempre implacable". Su poética personal no se sustenta, pues, en ese cinismo o en ese escepticismo existencial tan propio de la poesía de esa corriente hegemónica. Sin renegar en absoluto de la clarividencia que se supone tras esa visión, sabe ir más allá, dar otra vuelta de tuerca, optar por un distanciamiento sano y provechoso, menos apocalíptico, pero igualmente lúcido, preciso y, por supuesto, necesario. 
Acto III de la Tragedia de san Hermenegildo, cumbre del teatro jesuítico español, algunos cuentos, facecias varias y una crónica de festejos taurinos), destaca, en efecto, por la búsqueda de la perfección estilística, pero va más allá del tan manido formalismo que le achaca la crítica. "Esta visión un tanto parcial que se ha tenido del poeta Arguijo ha sido alimentada por una ausencia total de cualquier referencia al paisaje y a mujeres que no pertenecieran al ámbito del mito o la historia antigua" (p. 59). Si bien es cierto que en la poesía del venticuatro no dominan los temas amorosos ni la introspección íntima, aspectos que pudieran vincularlo con la tradición petrarquista, coincidimos plenamente con el editor en que sus poemas destilan un cierto análisis del yo: describen a un hombre sumido en la amargura y en la desesperanza. Un hombre que de la gloria pasó al olvido.

En efecto, Oriol Miró nos invita a leer de otro modo a Juan de Arguijo; nos lo aproxima a la vida, lo rescata de cierto preciosismo marmóreo, aunque no puede obviar que sus exempla y el tratamiento del amor (que colinda con temas co- mo la fugacidad del tiempo, las ruinas, las mudanzas de la fortuna, y la amistad) responderían a una asimilación de la moral horaciana y el neoestoicismo, que anteponen la consecución del bien a la obtención del placer. También añade que su aproximación al mundo de las emociones $\mathrm{y}$, en concreto, al universo femenino le resulta siempre incómoda, debido a un cierto desapego maternal, y a un matrimonio desprovisto de pasión.

En lo concerniente a la temática, estudia con rigor la impronta del contarreformismo jesuítico, el conocimiento directo de la historia clásica y la pervivencia de todo un universo mítico (Grecia Roma y Troya) que le brindaría un repertorio de valores ejemplares como el honor, el heroísmo o la virtud estoica. Destaca el estudioso que Arguijo acude directamente a las fuentes en latín: las Metamorfosis de Ovidio, la Eneida de Virgilio o las Geórgicas y Bucólicas, pero que halla en Horacio el sentido último de su poética, esto es, la concepción moral compartida por los poetas renacentistas de que la creación perdura más allá de la muerte, de tal modo que sus poemas funcionan como estampas morales. 
detalle hasta qué punto su vida influyó en su obra, consideración que le lleva a reconstruir su biografía para comprender cómo su poesía, que a simple vista pudiera parecer un mero corpus de composiciones mitológicas o históricas, fue, en verdad, el resultado de expresar en verso su pasión por la cultura clásica, pero también su experiencia vital, agitada y contradictoria. Juan de Arguijo heredó de sus progenitores un verdadero imperio comercial; empujado por su padre a entrar en política juró la venticuatría y conoció las mieles del éxito. Casóse por conveniencia con Sebastiana Pérez, y entró en contacto con la Compañía, de la que recibió una valiosa protección, amén de familiarizarse con los principios éticos de la literatura clásica, tan afines al cristianismo jesuítico contrarreformista.

Por aquel entonces, la ciudad del Betis era la cuna de la cultura humanística; las obras de Herrera (Anotaciones a la poesía de Garcilaso), Jáuregui (prólogo a sus Rimas), Mal Lara (prólogo a su Filosofía vulgar) y Medina (prólogo a las Anotaciones de Herrera y Apuntamientos y notas a los sonetos de Arguijo) ennoble- cían los cenáculos literarios en los que Arguijo ocupó un destacado lugar como mecenas.

Sin embargo, el poeta dilapidó sin orden ni concierto toda aquella fortuna. Algunos gestos de inusitada ostentación le acarrearon un gran desprestigio en aquel círculo intelectual, donde pasó de encarnar al perfecto cortesano a ser considerado como un personaje ególatra y caprichoso. Este fatal declive, muy bien rastreado por Miró, le induce a sostener que en Sevilla pudo existir una academia literaria en la que la reflexión creativa conviviera con las pullas literarias, habida cuenta de algunos versos ofensivos y crueles que sobre el poeta circularon por la ciudad. Y sobre todo le lleva a ahondar en una grave crisis que lo apartó del mundanal ruido, hasta que años después volvió a la vida literaria y, según parece, recopiló y corrigió sus sonetos, siguiendo las indicaciones del maestro Medina.

Su obra, conformada por sesenta y siete sonetos, tres canciones, tres silvas, un poema en esdrújulos, un poema en tercetos, dos décimas y una epístola, así como algunas incursiones en la prosa (el

RAFAEL BONILLA CEREZO, SUSPIRANDO A MUSIDORA. ENSAYOS DE LITERATURA Y CINE. DIPUTACIÓN DE CÓRDOBA, CÓRDOBA, 2008, 378 PP.

ISRAEL MUÑoz GALLARTE RIJKSUNIVERSTTEIT GRONINGEN

El nombre artístico de la famosa vampiresa francesa Jeanne Roques, de principios del siglo pasado, es el bello personaje femenino que da título y sentido a la presente obra del Prof. Rafael Bonilla Cerezo, Suspirando a Musidora. Su autor, uno de los más claros exponentes de la investigación centrada en el Siglo de Oro y el período Modernista de la literatura española, atiende, en esta ocasión, a un tema aparentemente distinto, pero interconectado, como es el análisis de afamadas películas y su relación con ciertas obras literarias españolas. El resultado, a modo de introducción, puede ser clasificado como "literatura a la luz del cinematógrafo y viceversa", un interesante ensayo sobre có- 
mo la literatura y el cine se han imbricado y alimentado mutuamente desde el 28 de diciembre de 1888.

Como el autor advierte en su prólogo (pp. 11-17), el viaje propuesto en sus distintos trabajos es ante todo personal, intimista: una selección de artículos escritos durante los años 2003 y 2005, cuyo principal nexo de unión es su pertenencia a un mismo autor, quien, en su peculiar estilo abigarrado, explora los límites del cine y la literatura.

El primero de los capítulos, "Salomé danza ante los tetrarcas modernistas: Valle-Inclán y Castelao. Plástica, caricatura y cine en un mito de Wilde" (pp. 19-52), comienza con la exposición de las características básicas del mito bíblico: la danza de la idumea ante Herodes y la petición, erótica y sádica, de la cabeza de Juan el Bautista en una bandeja de plata. A continuación, Bonilla atiende al desarrollo diacrónico del relato, confeccionado en sus puntos principales por Wilde en Salomé y reinterpretado por Valle-Inclán en clave esperpéntica en $L a$ Cabeza del Bautista. Para conseguir esa degradación, el dramaturgo gallego posiblemente siguiendo modelos popu- lares como el "Fausto Criollo" de Estanislao del Campo - estereotipa a sus personajes, deshumanizándolos, como títeres construidos en torno a una idea o cualidad: Don Igi-Avaricia, PeponaLujuria y Jándalo-Muerte. La peripecia, producto de estos tres valores, se desarrolla con el deseo amoroso del viejo Don Igi hacia Pepona, que, al igual que Salomé, ejercerá el dominio propio de una "femme fatale grotescamente deformada". En esta relación, cargada de morbosidad, entra la tercera punta del triángulo amoroso, el Jándalo. Planteada la situación, el autor trae a colación las referencias cinematográficas de Pepona: las más evidentes, Theda Bara en Salomé (1918) y Alla Nazimova en la película homónima (1923), pero también menos fáciles de intuir como Marlene Dietrich en El ángel azul (1930). El final trágico es necesario para este planteamiento y seguirá el esquema griego de hybris, ate y nemesis: Jándalo aspira a un amor imposible y, cegado por esta pasión, no observa los indicios que le advierten, por lo que recibirá el castigo de mano de la mujer a la que desea.

\section{JUAN DE ARGUIJO, POESÍA COMPLETA, ED. DE ORIOL MIRÓ MARTÍ, MADRID, CÁTEDRA, 2009, 308 PP.}

GLORIA LLEVET PLANAS

Esa fue la gran aportación del poeta Arguijo a la literatura. Y la perfección formal de sus sonetos. Y la recuperación de un legado histórico y mitológico que contribuiría a enriquecer, y mucho, el humanismo castellano de la España de los Siglos de Oro. (p. 63).

Con estas palabras, con este polisíndeton casi infinito pero contundente que cierra la Introducción del libro que nos ocupa, demos la bienvenida a la Poe- sía Completa del poeta Juan de Arguijo, en la magnífica edición crítica de Orio Miró Martí. Una edición que destaca sobremanera por el cuidado filológico, así como por el conocimiento profundo del legado literario de la escuela sevillana, y por extensión, de la literatura italoespañola del Renacimiento

Juan de Arguijo (1567-1622) fue un poeta peculiar. Oriol Miró explica con 
En este contexto, Bonilla hace hincapié no sólo en la influencia que la literatura pudo ejercer sobre las obras fílmicas, sino también en cómo el dramaturgo gallego compuso una obra teatral cargada de elementos cinematográficos, que se pueden rastrear, sobre todo, en sus anotaciones de escena y en el ritmo de la tragedia.

En la misma línea que el anterior, el segundo capítulo, “Max Aub y La vida conyugal: triángulo amoroso, drama policial, anarquismo en sombras plateadas de cine" (pp. 53-85), plantea el análisis de la obra de Max Aub, calificada de "drama policial", a la luz del cine negro clásico americano, principalmente. En opinión del autor, la primera característica cinematográfica de la obra es su intemporalidad, asemejándola a Las arrecogías del beaterio de Santa María la Egipcíaca (1974), El espíritu de la colmena (1973) o El Sur (1983). En cuanto a los personajes, son descritos claramente: Ignacio, empobrecido escritor utópico de ideología izquierdista, "inmutable ante los problemas del hogar", entre los que destaca su relación con su esposa, Rafaela; ésta es su contrapunto, tradi- cional y sencilla mujer apegada a su hogar, con claras referencias a la protagonista de El mundo sigue (1963); Samuel, amigo de la infancia de Ignacio, es el anarquista de la acción, comprometido con la causa; y, finalmente, la suiza Lisa, a diferencia de Rafaela, interpreta una mujer idealista y bohemia que ha tenido recientemente una aventura amorosa con Ignacio. Estos personajes orgullosos e idealistas, pero derrotados y cansados, se ven acorralados por el antagonista, Rubio, un delator favorable al régimen, a quien, tras un enfrentamiento verbal, Samuel acaba descerrajando un disparo.

Las escenas rememoran películas como The rope (1948) - basada, a su vez en otra obra teatral-, The Maltese Falcon (1941) o Casablanca (1942).

Siguiendo el hilo argumental, Samuel debe exiliarse - tras una escena, bien comentada por el autor del volumen, en la que se atestigua la influencia fílmica en el modo de contar el paso de tiempo hasta su marcha; sirva de ejemplo High Noon (1952) - - El clímax de la obra se produce después del enfrentamiento de Rafaela y Lisa, decidiéndose 
relativamente a favor de la esposa. Ésta, ante la llegada de los policías en busca de respuestas por el crimen cometido, al estilo de Antígona, se autoinculpa con soledad sofoclea, redimiendo así su propia angustia y cayendo con decoro.

"Cinetrompa y espiriletra en $L a$ lengua de las mariposas" (pp. 87-133) y "Mariposas y tilonorrincos en el fantascopio republicano" (pp. 299-335) abordan la adaptación cinematográfica, a cargo de José Luís Cuerda, de tres relatos breves de Rivas: La lengua de las mariposas, Un saxo en la niebla y Carmiña. Para esto, el autor del volumen, con un lenguaje lleno de referencias a las novelas de piratas - reminiscencia de una obra importante para el desarrollo argumental, Treasure Island-, comienza contextualizando las obras elegidas para el posterior análisis y resumiendo los avatares que llevaron a término el proyecto cinematográfico. Posteriormente se inserta una secuenciación comparada de la película y los relatos, a fin de clarificar el vínculo que existe entre éstos, el problema de la enunciación, el trasvase temporal, los añadidos y las supresiones. Como conclusiones parciales de la comparación, el autor rastrea los referentes artísticos de los añadidos en el drama, como la visita de Don Gregorio a la casa de Moncho o la pelea del protagonista y José María con Goodbye, Mr. Chips (1939) - adaptación de la novela homónima de James Hilton-; el cruce de Moncho y Roque sobre el puente, interpretado como el paso a la madurez, con el Lazarillo de Tormes; la luz y el color con que se grabó la clase de Ciencias Naturales, homenaje a La merienda campestre de Manet. Finalmente, el desarrollo llega a su clímax al final de la película, cuando el protagonista, instigado por sus padres, lanza a su "eterno Quirón" piedras y aparentes insultos, incomprensibles para el ajeno a la relación paterno-filial con el maestro - una referencia fílmica más a This land is mine (1943) - . Termina el artículo con un interesante párrafo, elogio del profesor, haciendo uso nuevamente del lenguaje propio de las películas de piratas, para cerrar en una bella ringkomposition.

El segundo de los artículos mencionados contempla la película a la luz de una pregunta distinta: ¿cómo se reflejan las reformas educativas de la Institu- ros a la lectura, porque configuran un mosaico de puntos de vista, una variedad de perspectivas, que estimulan la profundización de temas vinculados con la producción dramática del gran toledano. 
crita con seguridad y exclusividad a Rojas, Santa Isabel, reina de Portugal. En este texto dramático, que no pertenece sin duda a sus mejores producciones, Rojas "se escapa de los esquemas del teatro hagiográfico", con un "único y modesto recurso a las tramoyas" (p. 239). De hecho se trata, sin duda, de una "tragedia palatina con leves incrustaciones de comedia de santo" (p. 249) y por supuesto, si tomamos en cuenta el modelo lopiano de tragedia (como El castigo sin venganza) parece evidente que el dramaturgo toledano se debate entre serias "dificultades [...] para evitar el maniqueísmo en esa estructura dual y para presentar con naturalidad el curso ineluctable de la acción trágica, sin efectismos novelescos de baja ley" (p. 249). La única obra hagiográfica de Rojas, en conclusión, podría cobrar significado en el juego político de facciones en la corte de Felipe IV, más que en la mera glorificación religiosa de una reina.

Conviene acotar la habilidad con que Pedraza estudia los lugares imaginarios en Persiles y Segismunda, tanto en relación con la fuente cervantina como en las ampliaciones escénicas que realiza
Rojas, destinadas evidentemente (como en otras obras) a enfatizar el efecto espectacular. Los elementos dramatúrgicos se relacionan con los "alardes escenográficos" de Rojas, quien, a diferencia de muchos de sus contemporáneos, en esta obra se explaya en detalladas instrucciones para la realización de los decorados, del atrezzo y de los movimientos de los actores.

Para cerrar los ejemplos, indicaremos, en el rescate de Donde hay agravios no hay celos, el enfoque por así decir global: une la apreciación crítica por una de las obras maestras de Rojas al estudio detenido de la trasmisión textual de la comedia y a la reseña de su formidable éxito escénico hasta el siglo XIX, con un sinnúmero de representaciones y adaptaciones. A las adaptaciones de Hartzenbusch y Luceño se dedican páginas muy instructivas, sin deseos de privilegiar a priori un estado prístino del texto.

En conclusión, podemos afirmar que la variedad de métodos es fascinante. Los diferentes destinatarios iniciales de los trabajos recopilados en este libro explican la heterogeneidad de los registros, que sin embargo resultan placente- ción Libre de Enseñanza? A partir de este eje central el autor trae a colación otros vínculos posibles con largometrajes como Dead Poet's Society (1989), How Green Was My Valley (1941), Mother (1926), Secretos del corazón (1997) y Un lugar en el mundo (1992).

Con todo, en opinión del autor, José Luís Cuerda compuso una película de estructura tríptica, al estilo de Cuentos de la luna pálida (1953), que une el estilo lírico del cine oriental de la nouvèlle moralité de Rohmer con la cercanía del pueblo, un relato "intrahistórico, casi lugareño".

El siguiente capítulo, "Homero en Galway" (pp. 135-159), tal vez inspirado por la exclamación del minuto 110 de The Quiet man (1952), “It's homeric, that's what it is!", llena de optimismo las páginas del libro en las que se atiende al clásico de John Ford. Para Bonilla el protagonista es "una versión alegre y expansiva de Ulises" y, por tanto, el argumento trata el regreso del héroe heleno a una Ítaca irlandesa más verde que la griega. Partiendo de estas ideas, el autor construye puentes con otros largometrajes: su paisaje con The Searchers (1956), el ambiente del pueblo irlandés con How Green Was My Valley (1941), la relación silente y física del protagonista con Mary Kate Danaher con The Long Gray Line (1955), la famosa carrera de caballos en la playa con Hangman's House (1928), las escenas en la cantina con The Wings of Angels (1957) y el fin del largometraje con Río Grande (1950), sin desdeñar otras referencias secundarias. Cierra el artículo una breve sección en la que se menciona la filmografía citada en las páginas previas.

"Literatura y filmicidad: El vocabulario de los balcones (Almudena Grandes, 1998) en Aunque tú no lo sepas (Juan Vicente Córdoba, 2000)" (pp. 161-217) da título al cuarto capítulo, centrado en el análisis de la adaptación cinematográfica El vocabulario de los balcones a partir de la obra literaria Aunque tú no lo sepas. La autora de ésta última, Almudena Grandes, representante de la generación de mujeres post-feministas que plantean el tema sexual con sinceridad, es un claro exponente de escritora hondamente influida en sus páginas por el cine. Sin embargo, no fue de su agrado el resultado fílmico, al tratarse de una interiorización muy visual de su novela, trans- 
formada y adaptada a la niñez del director, Juan Vicente Córdoba. Bonilla pasa a analizar con minuciosidad la obra literaria, como si de una película se tratara, para, a continuación, ofrecer una segmentación de Aunque tú no lo sepas y una comparativa de ambas. De su análisis se extrae una conclusión clara: "Frente a los que piensan que el cine traiciona la novela, sugiero que, en nombre de la propia literatura, la herida resulta inocua". Sin embargo, también se reseñan ciertos "chirridos" en el guión cinematográfico, como la fallida revuelta contra los grises, en la que se dan cita sólo cinco o seis manifestantes y dos guardias. Continúa el artículo evaluando la elección de la banda sonora, muy ajustada a la época en la que se desarrolla y al argumento. Por todo es plausible situar la película en el desarrollo del cine español a caballo entre la suburbana Perros callejeros (1977) y El Bola (2000). Finalmente, se examinan varios tópicos como la lucha contra la violencia animal o la melancolía del metraje, por la que el autor la vincula a la famosa trilogía de Kieslowski.
“Luciérnagas, tinta roja y una sombra de carmín: Marsé embruja Shanghai" es el título del quinto capítulo. Al principio del mismo se plantea una interesante cuestión: son sabidas las relaciones existentes realidad-ficción y literatura-cine, en las cuales los segundos elementos se suelen alimentar de los primeros, pero, además, existe una tercera para el autor, "la ficción que se nutre de la pantalla", siendo un ejemplo de este fenómeno El embrujo de Shanghai (2002) de Juan Marsé. Se trata, por un lado, de un relato compuesto mediante ficciones y mentiras, leitmotios de los personajes: Daniel relata una historia compuesta por su recuerdo y Nandu Forcat, inserto en la historia del primero, compone una segunda historia de tintes propios de la novela negra. Por otro lado, la tradición de los personajes es extensa: Blay interpreta la figura del viejo chiflado de la novela picaresca en un paisaje esperpéntico; Susana, a su vez recuerda a las protagonistas de Lolita (1962) y Sleeping Beauty (1959); y, finalmente, Anita, a la heroína noir de The Lady from Shanghai (1947). crítica al menos hasta mediados del siglo $X X$. Sin embargo, no hay duda de que estamos hablando de uno de los dramaturgos más interesantes y complejos del Siglo de Oro.

Pongamos algunos ejemplos de la precisión del trabajo. En "Las graciosas de Rojas Zorrilla", se estudia un aspecto peculiar (y menos trillado) del consabido 'feminismo' del autor. En este ensayo el crítico subraya una observación metateatral (en Peligrar en los remedios): “Ello es fuerza/ que el gracioso y la graciosa/ sigan su propia tema..." (vv. 2885-2887), que introduce la idea de que para Rojas puede haber un papel femenino cómico, 'simétrico' al habitual donaire masculino. Estos personajes no "deben confundirse con $[. .$.$] las damas grotescas y risi-$ bles que abundan en Rojas (feas, desinteresadas del amor ideal, a la caza del varón...) como doña Hipólita y doña Beatriz en Abrir el ojo, doña Matea en Lo que son mujeres, doña Alfonsa en Entre bobos anda el juego...". A continuación, el estudio de las graciosas rojianas presenta un catálogo, que incluye al menos doce personajes en igual número de obras, para pasar a una fenomenología de este tipo dramático ("La dudosa fidelidad de las graciosas: alcahuetería e interés", "Elogios de la promiscuidad"; "Un caso de adulterio"; "Murmuradoras, borrachas y golosas"; "El retrato misógino de las graciosas"; "Referencias metateatrales"; "Escenas de lucimiento"). A pesar de la tradición misógina de la literatura y del tópico de la mujer fuente de "pecados y maldades",

las graciosas son criaturas simpáticas, que resultan atractivas, incluso admirables, al espectador. Quizá porque representan de forma más drástica y decidida que el gracioso los contravalores que dictan la inteligencia y el sentido común frente al universo idealizado hasta el encorsetamiento de las damas y los galanes positivos. (p.82).

Al concluir el ensayo, el crítico enfatiza la peculiaridad de la graciosa rojiana, que "tiene escenas de lucimiento y brillantez, y su caracterización, jocosamente degradadora, se compensa con la simpatía que despiertan su desparpajo y su aguda visión de la realidad social" (p. 86).

Para dar muestras de la variedad de enfoques que indicamos más arriba, veamos ahora otro artículo, que se centra en la única 'comedia de santos' ads- 
trabajos sobre Rojas. No se trata pues de una monografía strictu senso, sino de un panorama de las visiones críticas y filológicas. Si solo de esto se tratara, ya habría que saludar con regocijo la publicación de este libro; pero, además, su lectura permite ahondar en el conocimiento de Rojas desde distintas perspectivas, de la crítica textual al estudio de la conformación escénica imaginada por el autor, de la recepción a lo largo de los siglos a la presencia de la música, sin olvidar la evaluación crítica de los textos rojianos.

Cierta heterogeneidad de los trabajos, pues, no configura una dispersión de los enfoques críticos, sino que permite visiones diversas, da relieve a la figura del dramaturgo áureo, tanto o quizás hasta más que una monografía atenta de igual tamaño. Queda claro que, a diferencia de una obra sistemática, hay algunos aspectos menos tratados que otros (obras que apenas se citan, como por ejemplo Morir pensando matar, El Cain de Cataluña, Nuestra Señora de Atocha, o en ámbito temático, la presencia de fuentes bíblicas y medievales en el corpus rojiano, los problemas de autoría, o la delicada cuestión de la íntima postura del dramaturgo ante la convención escénica de la honra, pero no cabe duda de que esto obedece a una selección muy atenta y específica del autor, que remite con mucha atención a la abundante bibliografía rojiana). La gran variedad de cuestiones presentadas compensa con creces esta falta de sistematicidad: el lector tiene ante sus ojos un panorama crítico muy variado y muy esmerado.

El material está subdividido en cuatro bloques: "Sobre la comicidad y la figura del donaire"; "Estilo y temas"; "Textos y contextos"; "Parentesco estético y recepción escénica". No cabe duda de que la atención se centra con moderada prevalencia en las piezas cómicas de Rojas, en que el talento del toledano posiblemente tenga más espacio para desarrollarse. Pedraza, con toda razón, observa que Rojas no consigue la altura de Calderón en cuanto a estilo, versificación y soltura de la dramaturgia en las obras 'serias', porque muchas veces se deja llevar por el afán de construir algo novedoso, llegando a complicar en exceso la trama de sus obras, lo cual le valió una estimación reducida por parte de la
A continuación, el autor aporta otros referentes fílmicos de la obra literaria, desde Casablanca (1942) a Three Godfathers (1948), para exponer, finalmente, las similitudes o constantes de $E l$ embrujo de Shanghai, El espíritu de la colmena (1973) y El Sur (1982) con el cine de Von Sternberg.

Termina el volumen con "El teodolito de Aristarain: Un lugar en el mundo", descrito por su autor como "un cuento sobre la solidaridad en los sueños, el placer y la tristeza" (pp. 338-376). Las primeras páginas se dedican a situar la película en la filmografía de Aristarain. Tras esto, dibuja mediante precisos trazos a los protagonistas y el largometraje: Luppi y José Sacristán interpretan personajes llenos de dignidad, derrotados pero no vencidos, y la película se compone de largos planos secuencia y primeros planos, con un ritmo casi "literario" y gusto especial por los espacios abiertos, al estilo de John Ford. La investigación se centra, seguramente por la profesión del autor, en el tópico de la enseñanza: en primer lugar, en la de Domenicci y sus alumnos, en la que se rastrea el ideario krausista y el ruralis- mo de la Institución Libre de Enseñanza y, en segundo, la de Hernesto y Luciana, cargada de sensualidad. Tanto por el planteamiento, como por el fondo de la película, denuncia de la tecnocracia que intenta acabar con una Edad de Oro previa a la revolución industrial, el largometraje parece partir de distintas tradiciones como The Grapes of the Wrath (1940), How Green Was My Valley (1941) o The Quiet Man (1952). Termina el artículo y el libro con una breve bibliografía de la filmografía citada en el último capítulo

Una vez descritas las líneas principales del libro, pasamos a reseñar ciertos detalles del mismo. Así, la obra, a pesar de estar escrita de manera excelente adolece de una cierta falta de unidad estructural, es decir, al tratarse de una serie de artículos escritos durante un intervalo de tres años, es inevitable retomar ideas o tratarlas de otra manera - como bien advierte el autor en la n. 1 p. $301-$, pero los ejemplos denotan que no sólo las ideas, sino también las palabras, e incluso la bibliografía son utilizadas literalmente en distintas ocasiones, sirvan de ejemplo: 
El tema de la existencia o inexistencia del narrador en el cine se trata en la p. 109 y, prácticamente en los mismos términos, en la n. 51, p. 195.

Si es más sencillo adaptar un cuento o una novela es otro de los tópicos mencionados en las pp. 92 y 171.

La descripción de la Institución Libre de Enseñanza es un tema sobre los que vuelve el autor, haciendo uso de palabras semejantes; cf. pp. 311 y 347.

La opinión acerca de la fidelidad del largometraje con el libro es tratada, incluso insertando las mismas citas de Gimferrer, en las pp. 172-173 y 226.

También se echa en falta una serie de elementos ya acostumbrados en este tipo de obras, a caballo entre el texto científico y el ensayo literario, como un índice de obras mencionadas, de tópicos o de toda la filmografía citada completa,

lo cual facilitaría su uso. De hecho, se insertan dos filmografías mencionadas al final de los artículos cuarto y octavo, quedando el resto sin mención alguna. Finalmente, el lector espera que, aunque se trate de análisis tan diferentes, el autor extraiga alguna conclusión que aúne los trabajos, pero ésta no existe. Sin embargo, creemos que el libro, a pesar de los inconvenientes mencionados principalmente de edición-, tanto por el tema que trata, como por su acribia y profundidad, por su excelente calidad literaria, por lo sugerente y erudito de muchas de sus hipótesis, debería conservarse en los anaqueles de cualquier especialista o interesado en el tema de la Filología Hispánica y del cine.

FELIPE B. PEDRAZA JIMÉNEZ, ESTUDIOS SOBRE ROJAS ZORRILLA CUENCA, EDICIONES DE LA UNIVERSIDAD DE CASTILLA-LA MANCHA, 2007 (CORRAL DE COMEDIAS 21), 356 PP.

DieGo SíMIN

La celebración del IV centenario del nacimiento del gran dramaturgo toledano dio pie para que distintas entidades se encargaran de solemnizar la efemérides, aunque sin lugar a dudas su ciudad natal, y la Comunidad Autónoma en que hoy recae, fueron las que más brillo le otorgaron. De hecho, los centenarios no sólo cumplen la función de estimular nuevos estudios, nuevas evaluaciones de la importancia de la obra de un autor, en este caso Rojas Zorrilla sino que también permiten realizar ba lances, crear un "estado de la cuestión" para poder centrar el panorama crítico sobre un artista.

En el caso que nos interesa, Felipe Pedraza propone una selección de sus 
citados (y que, a su vez, arrancan del magnífico prólogo de Martínez Sarrión a la antología ya señalada), se ilumina con la inclusión de un análisis profundo de aquellos poemarios de los cuales, por permanecer total o parcialmente inéditos, no existía hasta el momento ningún comentario previo. Tal es el caso de: $E l$ cerco de la vida (1947), La sal de Dios (1948), El otro aspecto (1953) o El libro de las premoniciones (1972-1981). Aquí se halla, sin duda, la parte más jugosa de este libro, donde se revela en qué modo se fue produciendo la evolución de un poeta cuya obra resulta tan radicalmente distinta, fresca, original y visionaria de un poemario al siguiente. La meticulosa interpretación de los textos realizada por Mario Paz González viene a limar asperezas entre las distintas etapas, a iluminar puntos oscuros o de fricción entre ellas, mostrando la sólida coherencia de conjunto de una producción poética singular como pocas. A todo esto contribuye el hecho de que, como colofón a cada capítulo, se estudien los poemas que en esos años Carriedo fue publicando en múltiples revistas o de aquéllos otros que, en muchos casos, ni siquiera llegó a dar a la imprenta.

A esta interpretación y búsqueda de unidad de la obra del poeta contribuye en buena medida la segunda parte del libro, el bloque denominado “Textos", que a su vez se divide, como hemos apuntado más arriba, en dos subpartes: estudio de los temas y estudio de los elementos formales de su obra, además de un pequeño apartado dedicado a la prosa. En el primero, el autor pretende "vislumbrar esos elementos comunes que, a menudo, se pueden percibir a lo largo de sus libros y que van más allá de corrientes e influencias, que recorren su obra de forma transversal, desde sus inicios más remotos, llegando a las que se conocen hasta la fecha como sus últimas composiciones". Observamos así cómo, efectivamente, hay una serie de temas que se han ido incardinando de modo gradual a la producción de Carriedo: la presencia constante de la muerte y de las premoniciones; la reivindicación de la soledad y de los espacios que la acompañan, así como de su contrapunto, la solidaridad; el elemento autobiográfico, en el
Recuerda al lector que en el manuscrito que se conserva del siglo XVII (Sesenta sonetos de Don Juan de Arguijo Veinticuatro de Sevilla) intervinieron dos copistas, e insiste en que, para evitar errores y para que el lector maneje más ágilmente su cuerpo de notas, prefiere obviar esa bicefalia textual.

Así pues, el testimonio ARG, esto es, los Versos de don Juan de Arguijo. Año de mil y seiscientos y doce, se considera su testimonio apógrafo, por cuanto pudo, según muchos indicios, ser revisado por el autor en su período de reclusión. Ocupa el primer lugar de la célebre antología Cisnes del Betis (1612), que incluye composiciones de poetas como Rioja, Herrera y Lupercio Leonardo Argensola. El testimonio ARG recoge sesenta y cuatro sonetos, dos canciones, dos silvas y una epístola.

Miró aclara, debidamente, que este testimonio tiene su origen en una recopilación perdida, la cual dio lugar a los Apuntamientos y notas del maestro Francisco de Medina a los sonetos de don Juan de Arguijo, esto es, los consejos que Medina realizó al conjunto de los sesenta y dos sonetos que Arguijo le enviara, confiado en las prestigiosas dotes enmendadoras del mismo.

Según el editor, en sus Apuntamientos (1599), amables y concisos, Medina procuró, antes que nada, reordenar la poesía arguijiana para convertirla en un cancionero poético, sin desestimar la temática histórico-mitológica y moralizante. En las notas críticas se arguye que el objetivo último sería ajustar la forma de la composición poética para que contribuyera a la consolidación de una estética literaria en lengua vulgar, habida cuenta que el veinticuatro tendía, por su formación humanística, a retorcer la expresión con una sintaxis y un léxico latinizantes. Sin género de dudas, Miró considera esencial este compendio para explicar la génesis de la lengua poética española, y acierta, de nuevo, al recomendar al lector que consulte atentamente los comentarios de Medina mientras lee los poemas.

Varios motivos nos incitan a demorarnos en cómo Miró ha trabajado el manuscrito ARG.

En primer lugar, ha mantenido el orden de las composiciones pero ha in- 
dicado el que pudieran ocupar en otros testimonios.

En segundo término, y con excepción del soneto XII "Psiche a Cupido", ha preferido incorporar un título entre corchetes, a pesar de que Arguijo los desterrase en su última revisión; así el lector los puede recordar y relacionar con mayor facilidad. Del mismo modo, ha desestimado algunas falsas atribuciones, y ha dedicado un apartado adicional a los poemas no incluidos en Cisnes del Betis.

En tercer lugar, y esto dice mucho de las intenciones pedagógicas y analíticas con que el estudioso ha editado al poeta sevillano, nos ha brindado tres poderosos cuerpos de notas. En el primero y segundo se recogen los Testimonios y Variantes, indicados en alfabeto; se deja constancia de todas las variantes textuales, y se comparan con el testimonio ARG. En el tercer cuerpo de notas, Miró comenta, con audacia y rigor, algunos contenidos fundamentales para comprender, en toda su amplitud y hondura, la poesía de este sevillano a quien la historia, por el momento, no ha hecho justicia.
Lo más reseñable es que, en este cuerpo de notas críticas, se entreveran las alusiones a los Apuntamientos de Medina, reproducidos, con tan buen criterio, al final de este volumen, con una descripción de los recursos formales y del complejo mundo poético arguijiano.

Así, nos sorprendemos, entre otros asuntos, ante el rastreo minucioso de los latinismos léxicos y semánticos de su poesía, la explicación de determinados episodios históricos, o los avatares de una serie de personajes griegos y romanos como Pompeyo o Cicerón. También conviene mencionar algunas aseveraciones filológicas que bien pudieran engrosar el estudio de la pervivencia de ciertos mitos clásicos en nuestra literatura áurea; caso de Homero, que ha embellecido la imaginería popular desde Mena hasta Cervantes. También se detiene el investigador en cuestiones lingüísticas, y aclara determinados usos y variantes adjetivales que ganarían terreno en la literatura del Siglo de Oro. Estudia asimismo el origen clásico de algunas figuras retóricas (metonimias y sinécdoques), y detecta con precisión bastantes cultismos. libro, fruto de su tesis doctoral, ha sido el de optar por un esquema clásico para este tipo de trabajos, algo que, tratándose de una tarea tan amplia, resulta siempre de agradecer. Máxime cuando se trata de ofrecer una visión analítica del conjunto de una producción tan extensa como la de Carriedo. Por esquema clásico nos referimos a la opción del autor de dividir el resultado de su investigación en dos grandes bloques bien definidos, “contextos" y "textos" o, lo que es lo mismo, análisis de la vida y la obra, en el entorno humano y artístico en que se desarrollaron, y análisis de los temas y las formas que constituyen dicha obra. No es preciso destacar que ambos bloques son analizados con abundante y minuciosa profundidad.

Para el estudio de la vida del poeta, Mario Paz ha manejado multitud de fuentes documentales, algunas de ellas conocidas (como los estudios más arriba señalados) y otras totalmente inéditas. Entre estas últimas es en especial sobresaliente una parte de los diarios del poeta redactados al poco de su llegada a Madrid, cuando el Postismo daba sus últimos estertores, así como entrevistas en la radio y televisión o escritos del palentino poco o nada conocidos. Sobre todo, es de destacar, en este primer bloque, la aclaración de numerosos aspectos de la biografía de Carriedo que, hasta ahora, habían permanecido sin hila en toda su magnitud. Entre ellos su relación con el nonagenario poeta Fermín M ${ }^{a}$ García Sánchez, sorprendentemente localizado en su retiro murciano y entrevistado por el autor de este estudio También algunas vivencias relativas a los últimos años en Palencia y los primeros en Madrid, aportando documentación de gran interés sobre los happenings y otras "boutades" protagonizadas por los integrantes de esa vanguardia tan extemporánea que fue el Postismo. Además, el análisis de los últimos años de Carriedo, en los cuales estuvo vinculado al mundo de la arquitectura, como director de aquella emblemática Nueva Forma, y su interés de entonces por el Modernismo brasileño.

En lo que se refiere al estudio de la producción del palentino en el contexto en el cual se desarrolló, la estructuración por etapas, que remite en líneas generales a la realizada en los estudios previos 
de esto ha podido contribuir en exceso a dar a conocer una obra que, por sus cualidades innatas, hubiera necesitado una, a todas luces, mayor difusión. Porque Carriedo ha sido siempre un poeta de hoy y de mañana, es decir, un poeta querido, valorado y muy leído por otros poetas y en cuya obra, además de un constante amor por la palabra, se anticiparon siempre las líneas maestras de una poesía que presentaba una clara vocación de futuro.

Desde hace ahora más de veinticinco años, su amplia producción se ha venido recuperando en un proceso que engloba también a otros compañeros de aventura lírica. Primero fue, antes de su muerte, la edición de la antología de Hiperión de título perfecto, Nuevo compuesto descompuesto viejo (1980), a cargo de un estupendo poeta, ensayista y memorialista como es Antonio Martínez Sarrión. Luego una necesaria biografía firmada por Amador Palacios y una magnífica tesis a cargo de César Augusto Ayuso, que estudiaba por primera vez una buena parte de sus escritos. Más recientemente, Francisca Domingo recuperaba los últimos poemas del palentino en $E l$ libro de las premoniciones al tiempo que preparaba una antología hoy imprescindible, Poesía interrumpida (Huerga \& Fierro, 2006). A esta misma autora debemos un amplio estudio, fruto de su tesis doctoral, El constituyente imaginario en la obra de Gabino-Alejandro Carriedo. Finalmente, cabe señalar, hasta ahora, el colofón que han supuesto en esta labor de recuperación otras dos obras recientes. Por un lado la edición completa de su Poesía (Fundación Jorge Guillén, 2006), en la que se muestra la casi totalidad de sus composiciones, de las cuales más de la mitad habían permanecido inéditas en forma de libro. Por otro, este más que completo trabajo de investigación de Mario Paz González, que tendría el mérito de ser el primero en analizar con rigor y profundidad absolutamente toda la producción literaria del palentino, la publicada en libro y la diseminada en revistas, además de su, escasa, y tal vez menos interesante, creación narrativa.

La tarea, dicho en palabras del propio autor en el prólogo, podría pecar de "ambiciosa", por excesiva. Por ello, debe destacarse desde el principio que el enfoque adoptado al estructurar este
Destacaremos igualmente la importante labor llevada a cabo por Oriol Miró al establecer un paralelismo muy significativo entre la obra de Juan de Arguijo y la de Fernando de Herrera. En nota al lector, llega incluso a concretar el número de veces que en la poesía del venticuatro aparecen ciertos conceptos y fórmulas de la poesía herreriana. Del mismo modo, pone en relieve cómo tales recursos salpicaron la obra del resto de poetas sevillanos del Renacimiento.

En lo que a las cuestiones más formales se refiere, el editor ha preferido mantener las formas contractas de los versos, y respetar algunas grafías epocales, así como algunas alternancias vocálicas y consonánticas. Del mismo modo, ha demostrado una pericia notable al actualizar ciertas composiciones, acentuándolas según criterios modernos, as- pecto que siempre se agradece, y al puntuar algunos versos, con las consiguientes variaciones de significado, siempre, claro está, con las debidas notas comentadas. Ello no impide que el principa objetivo del estudioso haya sido en todo momento respetar los matices del texto original, constatando incluso cuán sutil puede resultar una exclamación, sentida con mayor o menor sinceridad, en boca del poeta.

Que esta edición que Oriol Miró Martí nos brinda con tanto esmero nos permita disfrutar de Juan de Arguijo, cuyo decir poético, hermoso y delicado, debe tenerse en cuenta por la verdad que encierra: "Que al fin es cosa cierta que se sigue/ tras la tormenta, guerra, noche oscura,/ buen tiempo, dulce paz, alegre día". Soneto LXIII [Esperanza], (p 246). 


\section{MARIO PAZ GONZÁLEZ, LA OBRA LITERARIA DE GABINO-ALEJANDRO}

CARRIEDO, LEÓN, UNIVERSIDAD, 2008, 538 PP

JUAN MANUEL FERNÁNDEZ ÁLVAREZ

La imagen del poeta GabinoAlejandro Carriedo se ha mostrado con un perfil borroso, de contornos poco definidos, a lo largo de muchos años. La razón de ello no hay que buscarla en la obra del poeta, perfectamente limada, templada y encaminada hacia un objetivo de pureza estilística y conceptual como pocas de entre sus contemporáneos. La razón de esa nebulosidad habría que procurarla, más bien, en las circunstancias extraliterarias en las que esa obra se desarrolló: pobre difusión a través de ediciones menores y con escasa tirada de ejemplares, excesiva dispersión de textos de notable interés en periódicos y revistas, fáciles encasillamientos en los que ha caído a menudo la crítica y (¿por qué no?) también los lectores... En fin, parece evidente que nada 
tual española y andaluza. Tal vez el caso de Balbina Prior Barbarroja sea único, porque sí es verdad que, mientras otras y otros han tomado por la calle de lo cotidiano-personal que puede equipararse con lo universal, ella es la única, único poeta que ha tomado su propia calle de enmedio para hacer la poesía universal, para contar, no la crónica de lo íntimo, sino la crónica social que es, también la universal y por la cual tal vez se nos recuerde a los sobrevivientes de este tiempo convulso, lleno de cambios y nuevas adaptaciones, el tiempo "sin subvenciones", el de la Edad Desnuda.

FIDEL SEBASTIÁN MEDIAVILLA, LA PUNTUACIÓN DEL QUIJOTE (1605 Y 1615). VIGO, EDITORIAL ACADEMIA DEL HISPANISMO, 2008, $160 \mathrm{PP}$

DESIRÉE PÉREZ FERNÁNDEZ

El presente trabajo supone una nueva muestra del interés y preocupación del autor por la puntuación de los textos literarios del Siglo de Oro y, en concreto, de las obras más relevantes de nuestra literatura. Tras observar la puntuación de obras como La Celestina, el Guzmán o el Lazarillo, Fidel Sebastián Mediavilla escoge como objeto de trabajo el Quijote. 
Los problemas que se derivan del registro y cotejo de la puntuación de algunos de los textos clásicos de nuestra literatura no son pocos (ausencia de normas que rigen tales cuestiones en la época, intervención de editores, impresores, cajistas o las del propio autor que, a menudo, podría haber acarreado numerosas corrupciones en el texto...). Estos inconvenientes, junto con los propios del texto en cuestión (ausencia casi absolutamente de puntuación en los manuscritos), aparecen reseñados en la introducción de la primera parte del estudio. Además, en la introducción de la segunda parte, se avanza el retroceso experimentado tanto en la calidad de la impresión (papel de peor calidad, pasta poco resistente, tipos burdos), como en la calidad ortográfica, lo que repercutirá sobremanera en la regularidad de criterios, existente en la Primera parte y no en la Segunda.

Para el análisis de la puntuación de la parte primera de la obra, el autor toma como referente la edición príncipe $y$, en concreto, el ejemplar R/ 28 que de la misma conserva la Real Academia. Para realizar comprobaciones recurre tam- bién a los ejemplares conservados en la Biblioteca Nacional, la Biblioteca de Palacio o la Biblioteca de Catalunya. De esta primera parte se ha realizado una cala aleatoria de 48 planas de la que se extraerán numerosos datos que ayuden a efectuar un estudio estadístico de frecuencias.

Por lo que respecta a la segunda parte, se utiliza también la edición princeps custodiada en la Real Academia (R/29). Y de nuevo, se realiza una cala de 48 planas, recurriendo, cuando sea necesario, a otras tantas ediciones y ejemplares que ayuden a determinar la puntuación del volumen objeto de estudio.

El grueso del libro lo conforman los apartados dedicados propiamente al estudio de la puntuación. Se analizan los mismos fenómenos en cada una de las partes del texto: el uso del punto y aparte, la sangría y la mayúscula inicial (1) el punto y seguido (2); la puntuación en los diálogos (3); las citas (4); la función metalingüística (5); las modalidades oracionales (6); las necesidades expresivas dentro de la frase (7); otros incisos (8); la enumeración de palabras y sintagmas mas : El “(T) De la inmortalidad poética", I y II, con la pregunta sin respuesta “¿A qué edad debe retirarse un poeta?", pregunta esta que encierra una irónica verdad/crueldad, pero que Balbina se atreve a formular; y la Teoría del Canon literario, este último una conversación, encuentro "tete a tete" y con té incluido, de la voz poética con una autora, no explícita, pero que por sus rasgos de circunstancia deducimos que se trata de Aphra Behn, a quien Balbina ha traducido del inglés: "Nadie, señora, nos recordará/ en la primera fila del Parnaso" (...) "pero no han de faltar algunas audaces poetisas/ que traigan flores o tabaco a nuestra tumba" (pág 31).

En "El árbol de la ciencia", los funcionarios controlan el perfil completo de cada individuo, desde el currículum académico hasta el ADN, y ahí se está denunciando la adoración al campo de "lo científico", ese ámbito sobredimensionado en nuestro tiempo y con tanta impostura superpuesta: "seguiremos atados/ con la dócil correa/ al árbol de la gaya ciencia." (pág 40).

También, en algunos poemas, esta Edad Desnuda parece alinearse con la actual crisis económica, como en estos versos: "las autoridades garantizan/ trabajo y víveres para pasar/ el invierno de la Edad Desnuda" (pág 51).

Como en un espectáculo televisivo, el dios al que todo se le ofrenda y en donde copulan realidad y ficción, se recrea, intertextualizada, la declaración de un soldado nazi, “Estaban desnutridos y no daban bien ante las cámaras" (pág 37).

En la última parte del libro, "Opúsculo incendiario", se incluye, como final, el poema "Sublevación en el gueto", alegoría del fin de nuestra cultura, o de esta era, en lo que se trata de una oposición a muerte entre "la autoridad" y el vecindario, que se refugia en bunkers contra la radioactividad después de haber sido antes atacados con sida y con gases y alzheimer, para terminar con unos versos rotundos de rebeldía: "Les enviaremos un mensaje cifrado/ desde las cloacas con honor,/ porque jamás nos rendiremos." (pág 52).

Da cuenta este libro de una realidad que, por sabida, no está mal que repitamos: la riqueza y la variedad de propuestas y lenguajes de la poesía ac- 
Como una banda enrollada que guardara dentro su muestrario - en este caso un muestrario general de la realidad-, se despliegan las diversas situaciones, aspectos de nuestra sociedad: En el "(T) En la aduana" hay "puertas diferentes para cada cultura» «y todo se reduce a sacar las automáticas, / escondidas desde siglos/ entre tu castigada piel y las cuatro tallas más/ de tus vaqueros vencidos» (pág 32) (...)«pues dentro de poco nuestra cultura/ no valdrá nada, y porque de todos modos,/ te la arrancarán del vientre/ como droga en la aduana» (pág 33).

En el poema "La cadena alimenticia", del III grupo, llamado "Timos asociales", se denuncia el turismo sexual, el tráfico infantil, juntamente con la hipocresía y el pillaje. «¿Por qué no instalan vigilancia contra el miedo?», se pregunta en el poema de la pág 41, "El cabo de cordada", en un quiebro de amarga ironía; y en la 42: «captados los suicidas/ de las bolsas de pobreza,/ se educan en el primer mundo/ con el dinero del miedo» (pág. 42, en "Recortes presupuestarios").
La ecología, los derechos de los animales, todo se muestra y todo se denuncia, y en esa denuncia está el tomar partido: la contaminación de los ríos, como en el verso referido a Jorge Manrique: «con tantas y tantas sustancias tóxicas mezclados» (pág. 15). O «hemos llegado al uso y al abuso/ de demasiados animales maltratados» (pág. 26).

Lo que más le interesa a la autora es plasmar este mundo, esta realidad, esta cultura del primer mundo que ahora intersecciona con el tercero, y donde los cambios son tan brutales que afectan a lo personal y circundante, aunque lo personal, ya lo hemos dicho, sean únicamente 2 ó 3 poemas, poemas siempre trasladables a lo común humano, como es el de la enfermedad, la heredad o el de "Envases e inertes": «hemos vuelto a pedir/ calderilla con faldas largas/ y pañuelo en la cabeza» (...)«Los viajes internacionales del Inserso/ van dejando un rosario de cadáveres/ concertados con funerarias extranjeras» $(. ..) \ll$ Los ancianos/ uno a uno se arrojan/ como envases y por inertes.» (pág. 39)

Entrelazado, el tema de la sociedad literaria, al que se dedican varios poe-
(9); los usos extralingüísticos de la puntuación (10) y las frecuencias de los signos de puntuación (11). La única diferencia manifiesta es la inclusión de un nuevo epígrafe en la segunda parte del trabajo que no aparecía en el primero: "algunos usos contrarios al común proceder actual, y errores manifiestos".

El registro de los casos que conciernen al uso del punto y aparte, la sangría y la mayúscula inicial (1) indica la ausencia de párrafos en la edición príncipe, el empleo de punto y aparte para acotar cartas, cédulas, notas, largas narraciones. Por su parte, el análisis del punto y seguido (2) deja en evidencia la existencia de numerosos errores, pues abundan los pasajes cuya puntuación resulta más que dudosa. El tratamiento de estos signos en la Segunda parte del Quijote es notablemente más copiosa. Con el punto y seguido ocurre todo lo contrario. Son numerosos los casos de la Segunda parte en los que debería aparecer. Sin embargo, se opta por un signo de menor entidad como la coma o el punto y coma.

En el caso de los diálogos (3), el inicio y fin del parlamento de cada per- sonaje aparece señalado. En el estilo directo se recurre mayoritariamente a los dos puntos, mientras que para el estilo directo se decanta por los dos puntos o por una coma seguida de "que". La Segunda parte mantiene los mismos moldes para tales casos, aunque se aprecia una menor uniformidad de criterios.

El caso de las citas (4) también resulta problemático desde nuestra óptica, ya que en la fecha no se incorporaban aún las comillas, para ello recurrían bien a un cambio de letra, a la introducción de los dos puntos o bien al empleo de la coma. El tratamiento de las citas en la Segunda parte apenas varía del realizado en la Primera, esto es, empleo de dos puntos o de coma. Sin embargo, no se apelará al cambio de letra.

Los casos en los que palabras o sintagmas adquieren valor metalingüístico (5) aparecen convenientemente reseñados ya sea mediante coma ya sea mediante dos puntos. Bien diferente es el tratamiento recibido en la Segunda parte donde este fenómeno no aparece acompañado de signo alguno de puntuación.

El empleo de los signos de interrogación y exclamación (6) es otro de los 
aspectos objeto del estudio. El examen de dichos casos concluye que únicamente se emplea el signo de cierre tanto en interrogativas directas como indirectas. Además se evidencia cierto desatino a la hora de colocar en su justo lugar dicho signo. Pero, además, dicho signo desempeña también labores estéticas al servir de colofón al final de algunos capítulos. Por lo que respecta al signo de exclamación, el examen concluye que tan solo es usado en dos ocasiones, lo que pone de manifiesto la escasa importancia y relevancia del mismo. En la Segunda parte únicamente se usará el signo de interrogación en las interrogativas directas. Pero lo realmente llamativo es la omisión y adición de dicho signo en ocasiones poco apropiadas conllevando no pocas dificultades de comprensión y numerosos errores. Tampoco en esta parte predomina el uso del signo de exclamación, ya que únicamente se registran diez usos.

El apartado dedicado a la puntuación de las oraciones yuxtapuestas, coordinadas y subordinadas (7) evidencia una falta de acuerdo. En caso de las yuxtapuestas y coordinadas parece exis- tir unanimidad, pues en el primer caso se recurre a la coma o a los dos puntos para separar las oraciones, $\mathrm{y}$ en el segundo, se tiende a colocar coma antes del nexo. En el caso de las subordinadas se observa la existencia de cierto acuerdo a la hora de puntuarlas, excepto en el caso de las consecutivas, finales y comparativa donde se aprecia cierto caos.

El análisis de los incisos (8) pone de manifiesto cómo los únicos incisos acotados son aquellos en los que se indica quién habla, mientras que en el resto de casos tan solo se indica su término. Lo mismo ocurre con las oraciones subordinadas insertas en otras proposiciones inmediatamente después de conjunción, o con las cláusulas absolutas y concertadas. Mayor variedad existe a la hora de acotar los vocativos o las aposiciones.

Por lo que respecta a la enumeración de palabras y sintagmas (9), el estudio señala que todos los elementos de la serie aparecen separados por una coma, coma que también se coloca delante de la conjunción.

En el apartado "usos extralingüísticos de la puntuación" (10), se someten de a la juventud. En algún momento, haciendo un correlato con el tiempo Cronos, se nos dice que la niñez dura 1 minuto, la adolescencia 30 segundos y la Edad Desnuda 15 segundos, porque tras de ella, o casi a la vez, llegan la enfermedad y el dolor: el despojamiento. Desaparecen los padres, tal vez la pareja, y no hay más remedio que plantarle cara a una realidad que se llena de nuevas responsabilidades.

Aunque en una primera lectura el lenguaje pueda parecer duro, rasante, sin apenas calificativos, también es cierto que las imágenes relampaguean sugestivas y poderosas: "muslos de cera", "la piel terciopelo de la aceituna", o "un bisturí de resplandeciente fuego" son algunas de esas imágenes que encontramos.

En la sección II, la de los "Timos Naturales", se sitúa por ejemplo, el “(T) De la angosta heterosexualidad": "pero si nos concedieran a todos/ la licencia de gozar en todos los frentes/ si socialmente no nos hubieran inhabilitado/ para cubrir toda clase de expectativas,/ no habríamos perdido la mitad del placer/ y quizás no habría tantas plazas de verdugo vacantes» (pág. 23). En el “(T) De la chapuza de la fertilidad" leemos: «Todo fue obra de una mente perversa/ y disculpable por su origen masculino/ que se reservó únicamente un papel placentero,/ mas nunca debieran haberle concedido/ a semejante chapuza el certificado de calidad» (pág. 24).

En el “(T) De la enajenada heredad" la voz poética se enfrenta a la venta, obligada por las circunstancias, del terreno de su infancia, una "loma de olivos" heredada de su padre y de su abuelo, lo que la autora utiliza para reflexionar sobre "la huida", el despoblamiento del mundo rural, que se traslada «como maltratado animal a la urbe».

El libro es una constante y mantenida reflexión/denuncia sobre la contemporaneidad, el capitalismo, la globalidad... en la que lo que late es la crónica diaria, general, de la devaluación de la condición humana y de los derechos clausurados y ofrendados a los dioses de la economía y del dinero «en un milenio vacilante de cambios» (...) «de seres y zonas reconvertidas sin anestesia» (pág 27). 
fiere a las edades de la humanidad, o de los humanos.

Cuando los poetas de mediana edad suelen ponerse a escribir elegías y a contemplar su vida, Balbina se empeña en seguir siendo testiga social de este tiempo, de su tiempo. Así, este libro trata del tránsito de las utopías, recorre el camino que va de la rebeldía a la realidad del consumismo, a la organización economicista, además de otras situaciones como son la inmigraciónemigración, las banderías de la situación política, la crítica de la posmodernidad, la alimentación, la basura, la guerra, el terrorismo... y la escritura poética junto con el lugar que las poetisas ocupan o dejan de ocupar en el canon y en la sociedad literaria.

Podría llamarse a esta "poesía social" si el término no estuviese tan manoseado y quizá, anquilosado, por connotado y denostado. Y enseguida habrá que decir que todo en este libro se escribe, por una parte, en lenguaje directo, pero por otra y al mismo tiempo, en lenguaje figurado, poético, con sugerentes imágenes y pleno de interconexiones, pero en donde el léxico parte, casi to- talmente, de lo actual, y obviando aquel otro hasta hace poco tenido por tradicionalmente "poético".

Casi nunca se escriben los poemas en primera persona, y aunque sí pueda comenzar con el pronombre o el verbo en primera persona, como para ser incardinado en una realidad cercana, enseguida y en el mismo poema se pasa a la segunda persona singular o a la primera del plural, al tú o al nosotros, como si la voz poética se propusiera dialogar con su tiempo, hacer siempre crónica general y no particular. También los escenarios y los elementos con los que se trabaja son plenamente actuales, lugares de paso y que indican tránsito: estaciones, autobuses, aduanas..., lugar ese del tránsito tan querido a la autora, que se sabe ciudadana del mundo y de la realidad multicultural e intercultural del mismo.

Podemos deducir, leyéndolo, que la Edad Desnuda es la edad en la que empieza el despojamiento de la vida, alli donde comienza el vislumbre de la poquedad del ciclo vital humano, que desemboca en la Estación del Silencio, así como la Edad de la Urgencia correspon- a estudio aquellos usos cuya finalidad no es otra que servir de ornamento y colofón a los capítulos.

Antes de las conclusiones el autor tiene a bien incluir un epígrafe en el que consigna la "frecuencia de los signos de puntuación" (11), con el fin de que podamos observar cuál de todos ellos es el más empleado (comas, puntos, dos puntos, paréntesis, interrogantes) y cuál el que menos (punto y coma, y signos de admiración). Los porcentajes extraídos del estudio de la Segunda parte atestiguan un aumento en el empleo del punto y coma y del paréntesis.
Para cerrar el estudio de la puntuación tanto de la Primera como de la Segunda parte del Ingenioso Hidalgo don Quijote de la Mancha, Fidel Sebastián Medivilla redacta las conclusiones a que tan detallado estudio le ha llevado. Estas no son otras que los resultados que ha ido obteniendo en el examen del uso y empleo de cada uno de los signos de puntuación registrados. Resultados que transcienden más allá del universo cervantino al arrojar luz sobre los modos y modas de puntuación y escritura de momento. 
BALBINA PRIOR, TIMOS DE LA EDAD DESNUDA, MADRID, SIAL, 2008, 56 PP.

JUANA CASTRO

Creo que fue un político andaluz, buen lector de poesía, quien me confesó que le gustaba leer poesía, entre otras razones, porque en ella encontraba la verdadera historia social, la de cada momento histórico, la interna y a la vez intensa, esa que no se encuentra en los clásicos libros de historia. Y quizá, leyendo la poesía de Balbina, pueda una llegar a entender los presupuestos de este político lector, porque en todos sus libros, y quizá más en los últimos, Balbina Prior quiere ser cronista - críticade su época. En 2001 publicó En los an denes de la Era Heisei, y ahora, a finales de 2008, este Timos de la Edad Desnuda. Pero mientras el primero hacía alusión desde su título, a una convención, el final de milenio, esta Edad Desnuda se re- 
periplo humano y literario de Joseph Roth, quien solía admitir la carencia de una casa y de enseres propios, a excepción de tres maletas. Una de las facetas de Roth, la del cronista periodístico, se desvela como en un negativo a lo largo de buena parte del libro y, especialmente, durante los primeros años. Como colaborador del suplemento cultural de Frankfurter Zeitung y de otros periódicos de lengua alemana, muchas cartas muestran la imagen interna del cronista, que, en ocasiones, es la del cronista frustrado. Censura aspectos crematísticos o de salud -el alcohol-, limitaciones de todo tipo, en suma, confieren a bastantes cartas un interés que trasciende la anécdota para iluminar la personalidad del novelista frente a la sociedad convulsa en la que se transformó Europa, tras la disolución del Imperio Austro-húngaro. Sin embargo, Roth es, ante todo, un escritor, no un periodista. Con las revistas y periódicos - escribe reseñas, artículos y crónicas - se gana la vida y se «promueve», pero, aunque también se hace famoso por sus artículos y crónicas destacan su viaje a Moscú de 1926 o sus crónicas berlinesas y parisinas-, Roth no puede renunciar ni un ápice a su concepto íntimo de escritura.

El 23 de abril de 1927 escribe al respecto en una carta dirigida a Benno Reifenberg, el responsable del suplemento del Frankfurter Zeitung: «No de tengo nada dinero. Me vi en la desagradable situación de aceptar un anticipo en el Prager Tagblatt - no soporto esta manera de viajar-. Soy lento, minucioso, me angustia la idea de que pueda ver algo falso, mi "estilo" no es otra cosa que un conocimiento exacto de la situación - sin él, escribo mal, como Sieburg en el suplemento de Pascua-. No soy un escritor del vacío. No tengo "ideas", sólo conocimiento.» (p. 124) La inmediatez, para Roth, es incompatible con la observación atenta del entorno y además con la pureza del estilo. De ahí que la calidad de los artículos publicados por Roth sea indiscutible, en ocasiones incluso superior a la de sus narraciones. Ya en su época no en vano se erigió en uno de los columnistas de mayor prestigio y más valorado de Alemania. En cuanto a la estructura interna de las Cartas, no queda otra opción que ser contemplada desde una perspectiva biográ- que se perciben nítidamente sus vivencias de la infancia y de la guerra; la presencia constante de la tierra y los elementos naturales que conforman el paisaje castellano, así como su valor simbólico; el componente social, inevitable en un poeta cuyo compromiso con la literatura no excluía un amplio compromiso vital; la reflexión metaliteraria; el mundo de lo cotidiano, así como temas con menor presencia pero, no por ello, menos importantes, tales como el amor o el elemento trascendente y la necesidad de respuestas a las preguntas existenciales.

Aunque menos atractivo, el recorrido por los elementos formales de la producción de Carriedo resulta igualmente necesario. En él Paz González trata de demostrar cómo buena parte de la producción poética de este autor se sustenta en un concepto de la obra artística proveniente de las vanguardias, lo que nos revelan algunos de los procedimientos de tipo léxico-semántico empleados por el poeta, tales como las palabrasclave y la simbología, así como el uso de tecnicismos, neologismos o la frecuente presencia del símil, la contraposición o la personificación. También, como parte de ese concepto de signo transgresor, estaría el uso del humor y la ironía, que translucen una visión lúdica del mundo manifestada a través de las abundantes animalizaciones y cosificaciones, el ingenuismo de signo naîf, la deformación del discurso, así como el uso de abundantes procedimientos desrealizadores del lenguaje como pueden ser el uso de vulgarismos y de expresiones coloquiales, o el gusto, en su etapa postista, por la provocación a través de la sicalipsis y la escatología. Además de la referencia a las figuras fonológicas de dicción o las alteraciones de rima y ritmo, es destacable el pormenorizado análisis de las formas poemáticas empleadas por $\mathrm{Ca}$ rriedo, que muestran cómo, a lo largo de su trayectoria, el poeta sintió una enorme preferencia por el verso endecasílabo, así como por el heptasílabo. Llama también la atención comprobar que, sin duda, podría decirse que fue uno de los mejores sonetistas de su época, aunque en los libros publicados en vida esta faceta permaneciese totalmente oculta.

El análisis de su prosa que cierra este bloque refleja que, lejos de una originalidad esperable a la luz de su poe- 
sía, su escasa producción narrativa se circunscribe en buena medida a las corrientes en boga del momento. La influencia del Postismo o de Cela es evidente en sus primeros textos, tal vez los más originales, aunque también se palpa un cierto gusto por el realismo en los últimos, entre los cuales se nos descubre uno publicado en Triunfo en los años sesenta y del cual no había noticia hasta su recuperación en este estudio.

Más allá de la amplia bibliografía final, tanto del autor como de las obras consultadas, correcta e indispensable como es habitual en este tipo de trabajos, llama poderosamente la atención el apartado de apéndices, pues en él se ofrece, por ejemplo, un más que minucioso "censo" de absolutamente todos los poemas de Carriedo, incluyendo referencias a su fecha de composición o de publicación, tanto en poemarios del autor, como en antologías o revistas. Su perfecta ordenación puede ser, desde luego, muy útil e iluminadora a futuros estudiosos de una obra que, hasta ahora, se encontraba en exceso desperdigada. También es destacable en este apartado la inclusión de tres poemas, así como de tres textos postistas todos ellos inéditos. Estos últimos sirven para entender mejor algunos aspectos de ese movimiento y cuál era la visión particular que Carriedo tenía del mismo. Como colofón se incluye el discurso de ingreso del poeta en la Legión de Humor, así como dos entrevistas inéditas ya mencionadas, la primera en Radio Estocolmo, en 1954, en pleno auge de la poesía social, y la segunda realizada por Andrés Trapiello en Televisión Española, poco antes de fallecer el poeta.

La de Carriedo es una lírica en la que cabe todo, lo irónico, lo sardónico, lo amargo, lo piadoso, pues se trataba de un poeta que vivió con plena intensidad la literatura y participó en primera fila en muchos de los acontecimientos de su tiempo. Para terminar, nos gustaría destacar la brillantez de las consideraciones, así como el estilo cuidadísimo (y, desgraciadamente, poco habitual) con que está redactado este libro. Al mismo tiempo, querríamos citar dos conclusiones que lo cierran y que consideramos muy acertadas. La primera hace referencia a la idea de que la vivencia en "los márgenes" de Carriedo no es sino una de una traducción y edición cuidadas de las mismas.

Sin las Cartas, igual que sin sus artículos, Roth se halla incompleto para quien desee adentrarse en el universo de su escritura. Y esta afirmación incluye el logro estilístico, propiamente literario, al margen del indudable interés biográfico o histórico. De ahí su suma importancia. Hay quien ha entrevisto en estas Cartas idéntico espíritu que el de algunas obras cumbre de Roth, como Judíos errantes y, sobre todo, Fuga sin fin. De hecho, un mismo espíritu, el del genial Roth, recorre toda su obra, sin apenas salvedades. Como explica Hermann Kesten en el Prefacio, las Cartas no fueron concebidas por Roth para ser publicadas y hoy podemos leerlas, en cierta manera, como un milagro literario e histórico. En palabras de Kesten: «Igual que el hombre que las redactó y la mayor parte de sus destinatarios, muchas de estas cartas padecieron el trágico destino de los perseguidos políticos de las dictaduras y la muchas veces mortal desbandada que suelen provocar los tiranos. Algunas fueron bombardeadas y gaseadas. Se las hizo desaparecer como si se tratase de testigos de cargo. Se suprimían las noticias penosas, la verdad incómoda. Yacen soterradas en los cementerios espectrales de una época asesinada con premeditación.» (p. 10). Conviene recordar, que tanto Kafka como Roth fueron «avisadores del fuego» - utilizando la terminología de Walter Benjamín-, que ambos eran de ascendencia judía y que ambos perdieron a sus amadas a manos de los nazis. Roth se exilió en París, huyendo de éstos y, de igual forma que Kafka murió antes de asistir a la peor parte de lo que se avecinaba. Las Cartas, por tanto, existen a pesar de su autor - quien las consideraba útiles sólo para sus propósitos inmediatos - y de la época turbulenta y trágica que le tocó vivir. Desde ambos puntos de vista, son conmovedoras. Traslucen de forma directa la obra pero también la biografía de uno de los narradores más importantes del periodo de entreguerras centroeuropeo. Las Cartas están dispuestas en orden cronológico, aunque las fechas tuvieron que ser deducidas muchas veces por su compilador.

Esta ordenación lógica de Kesten permite un seguimiento diacrónico de 
do, a un Max Brod, salvando la obra de su amigo Franz Kafka de unas llamas predestinadas por el autor. Es el caso de Hermann Kesten, también amigo de Joseph Roth y asimismo escritor y germanista. Éste abre el Prefacio del libro con una némesis simbólica de su relación con Roth: «Treinta años después de su muerte, mi más vivo recuerdo de Joseph Roth remite a una imagen en particular: estamos ante una mesa de café, en una calle de Berlín, París, Niza, Ostende o Ámsterdam; y escribimos, uno junto al otro, cada cual absorto en su propia labor».

Kesten, a pesar de confesar ciertas limitaciones como historiador de la literatura, se preocupa por lo que ahora es un texto compacto y fundamental, que se hallaba disperso, incluso perdido. En ocasiones, como la presente, la labor del filólogo se asemeja a la del investigador común, quien rastrea los conjuntos de epístolas por diferentes países y a lo largo del tiempo, hasta agotar las posibilidades. «Treinta años después de su muerte», lamenta Kesten. No es una novedad sensu strictu, porque, como es sa- bido, Kesten dio a la imprenta su encomiable labor en 1970 en Alemania.

Roth no fue nunca un autor olvidado, aunque debe tenerse en cuenta que el interés mayoritario de los lectores en lengua alemana se potenció, precisamente, a raíz de la edición alemana de las Cartas, base sustancial de la edición ahora vertida al español. Además, Kesten confeccionó las primeras obras completas de Roth -Werke-, que siguen siendo de referencia en la actualidad, publicadas en 1976 en Colonia. A este encomiable esfuerzo de Kesten, hay que sumar la biografía de Bronsen del 74. Tampoco se deben olvidar las contribuciones de Hermann Linden, Ada Erhart o Ingeborg Sültemeyer, entre las más destacadas de la bibliografía sobre Roth, en aquellos años cruciales para la difusión actual de su obra. En el ámbito de la filología hispánica, respecto a la obra de Roth, se han vivido unos años recientes con variadas y logradas traducciones la mayoría editadas en El Acantiladode buena parte de sus relatos y novelas. No obstante, la presente versión de sus Cartas viene a colmar la expectativa del lector en español, puesto que carecíamos reivindicación de «su propia exquisita libertad individual como baluarte único e inmejorable, como tabla de salvación ante esas circunstancias adversas que obligaban a una adscripción radical a una escuela u otra, a un bando u otro, a un compartimento estanco $u$ otro, pero también a desmarcarse al poco tiempo y con la misma radicalidad, de esas filiaciones febrilmente defendidas poco tiempo atrás». Por otro, la reflexión en torno al valor innato de la poesía que, en el caso del palentino y de sus compañeros de generación, sería uno de los móviles de toda su producción, ese «amor incontenible a la palabra como instrumento para la consecución, no sólo de belleza, sino también de comunicación artística plena, muy por encima de la realidad circunstanciada que les pudo haber tocado vivir». 


\section{JOSEPH ROTH, CARTAS (1911-1939), EDICIÓN Y NOTAS DE HERMANN}

KESTEN, BARCELONA, ACANTILADO, 2009, PP. 685.

JUAN CARLOS MERCHÁN RUIZ IES M. RODOREDA

Con este nuevo libro, Acantilado facilita al lector en lengua española una obra de gran calidad y, sobre todo, de enorme interés para concebir la narrativa de Joseph Roth de forma integral. En una cuidada edición, con traducción impecable de Eduardo Gil Bera, se vierten al castellano unos documentos privados tocados por la genialidad de uno de los mejores autores del siglo XX. Hay toda una historia, ya en origen, de la concepción del libro como tal. Cuando a la vida o a la obra de un escritor les persigue la adversidad - como es el caso de Roth - , ya sea personal o histórica -o ambas a la par-, nunca se agradece lo suficiente la intervención del amigoeditor. Quién no recuerda, en este senti- 
Vértices, mientras Aurora Saura aborda el mundo de lo onírico y la memoria como material poético para reivindicar la belleza olvidada. Diego Sánchez Aguilar disecciona la cotidianidad con unos versos cargados de humor e ironía, como muestran varios poemas de su libro Diario de las bestias blancas, sobre todo algunos en los que juega con múltiples referencias culturales de origen diverso, incluso aquellas extraídas del mundo de la televisión y de la cultura popular, como el poema titulado "Locus amoenus-barrius sésamos": "Un emisor y millones de receptores ante el mismo mensaje, / arriba, abajo, están dentro de la tarde y las meriendas". Aunque para ejemplo de prefiguración irónica del mundo están los "Pensamientos infames" de Vicente Luis Mora, en los que conjuga temas tan dispares como un comentario sobre la película En construcción de José Luis Guerín, con un haikai, o con alusiones exclusivamente literarias como una reflexión sobre Proust y Milton o un breve poema dedicado a Borges.

Otros autores que desfilan por la publicación son Luis Bagué, Raúl Quin- to, María Salvador, Alberto Hernández, Rodolfo Häsler, Ana Vidal Egea, Modesto Calderón; los mejicanos, de Chiapas, Nadia Villafuerte, Luis Daniel Pulido también María Rayo o Sergio Laignelet. Poesía dispar, heterogénea, rica en su variedad. En fin, como se anuncia desde el editorial: "El hecho de leer esta revista implica el encuentro no siempre feliz de poéticas encontradas, irregulares y a veces contradictorias entre sí. Pero en $H$ no entendemos la difusión de la literatura sin la apuesta por el riesgo, la imperfección y el hallazgo".

Por último, la sección de traducción corre a cargo, esta vez, de Ramón Dachs, quien bajo el epígrafe de "Una dulzura inusitada y nueva" reúne cuatro sonetos del Cancionero de Petrarca en una estupenda versión bilingüe que, gracias a la actualización plenamente poética que ofrece su traducción (pese a las dificultades innatas que ello supone), hace que se presenten totalmente vivos y llenos, como todo el contenido de la publicación, de una absoluta actualidad.

DIEGO HURTADO DE MENDOZA, POESÍA COMPLETA, EDICIÓN INTRODUCCIÓN Y NOTAS DE J. IGNACIO DÍEZ FERNÁNDEZ. SEVILLA FUNDACIÓN JOSÉ MANUEL LARA, CLÁSICOS ANDALUCES, 2007, CIII MÁS

694 PP.

DESIRÉE PÉREZ FERNÁNDEZ

La poesía completa de Diego Hurtado de Mendoza ya ocupa un merecido lugar en la Colección "Clásicos andaluces", que dirige el profesor J. Lara Garrido. De la mano de José Ignacio Díez Fernández, quien con anterioridad ya había editado al poeta, hoy podemos leer todas sus composiciones poéticas, incluidos aquellos versos omitidos, de manera voluntaria, por los primeros editores del poeta.

El prólogo al volumen, redactado y elaborado de una manera inteligentísima, te atrapa y envuelve desde las primeras líneas, invitando al lector a rellenar los vacíos registrados en la vida y obra del poeta. El silencio al que durante siglos fueron condenados algunos de 
sus textos y su manipulada biografía, plagada de éxitos y carente de sombras, quedan resarcidos con creces en dicho preámbulo.

El libro, tal y como es costumbre en la Colección, aparece introducido por una semblanza biográfica del poeta que, en este caso, sirve para desterrar, como ocurre en tantos casos, algunos de los tópicos que, durante siglos, se han cernido sobre la figura del poeta, y para evidenciar aquellas facetas menos conocidas o acalladas de la vida y obra del granadino.

La tan traída y llevada bicefalia de don Diego, que representaba magistralmente el papel de hombre de armas y de letras, es superada por el profesor Díez Fernández al adentrarse en las sombras del personaje. Sombras que resultan notablemente útiles y relevantes a la hora de trazar el periplo vital de este diplomático, historiador, bibliófilo, políglota y poeta que fue Diego Hurtado de Mendoza. Entre otros datos incómodos se reseña su doloroso regreso a España, la pérdida de Siena, el disfavor de Carlos V, el destierro en su Granada natal,... Encontramos, además, en esta biografía, no al uso, el repaso a algunos de los juicios vertidos en torno a la personalidad y obra del poeta que evidencian el subjetivismo y lo poco apropiadas que resultan en la actualidad las opiniones de aquellos, contemporáneos o no, que intentaron trazar un perfil del poeta. Antes de concluir, José Ignacio Díez Fernández reivindica la importancia del epistolario de don Diego, del cual se desprenden cuestiones como las preocupaciones del poeta o el calado de sus relaciones familiares.

Tras las líneas biográficas del poeta, el editor tiene a bien detenerse en las particularidades genéricas y temáticas de la obra poética. Sin duda, la más relevante es la dificultad de realizar un estudio de conjunto, dadas las copiosas dificultades derivadas de semejante tarea de edición (los numerosos procesos de atribución y autoría, la cantidad de manuscritos, la falta de un texto autorizado por el poeta, la posible autoría del Lazarillo,...). Si a las cuestiones propiamente ecdóticas, se suma el hecho de que al poeta le tocó compartir tiempo, espacio y vocación con Garcilaso y Boscán, parecen obvias las conclusiones de- sólo en números anteriores se alternaban en perfecto equilibrio nombres tan significativos y consagrados en el universo poético como Kepa Murua, Jorge Riechmann, Julia Otxoa, Felipe Benítez Reyes, Blanca Andreu, Chantal Maillard, Carlos Marzal o Vicente Gallego, con un denso número de creadores más jóvenes como Mercedes Díaz-Villarías, Mariano Peyrou, Antonio Lucas, Raquel Lanseros, Julián Cañizares, José Daniel Espejo, Luis Pablo Núñez o Joaquín Juan Penalva, todos ellos de reconocida calidad innata. Aunque cabría señalar que se observa una clara predilección por los autores de la llamada "Poesía de la experiencia", frente a la práctica ausencia de otras corrientes contemporáneas igualmente señeras. Pero esto no tiene porque ser una crítica negativa, ni mucho menos, es una opción plenamente aceptable y totalmente coherente.

Por otra parte, en varios de sus números anteriores se podía disfrutar de una pequeña sección, en las últimas páginas, dedicada a la traducción: Maurice Riordan, Nikiforos Vretakos, Odysseas Elytis, Danilo Breschi, Manuel de Freitas..., enlazando así con una tradición habitual en el ámbito de las revistas hispánicas que se remonta, sin ir más lejos, a aquellas publicaciones de mediados del siglo pasado como Garcilaso o, en el realismo social, Poesía de España.

Toda esta ejemplificación sirve para darnos cuenta del nivel de calidad de esta publicación. Nivel que viene a continuar y confirmar el número cinco que es el que aquí realmente comentamos y que, como dicen los responsables de la revista en su editorial, «nos encuentra aún sorprendidos, como en el primer número, por la amplísima variedad de lenguajes con que, de un autor a otro, se viste la poesía».

Si de las ilustraciones se ha encargado, con unas hermosas acuarelas, Pedro Cano, hiperrealista en sus inicios y ex-alumno de Antonio López, entre las colaboraciones poéticas destacan los originales haikais de Juan Bonilla que recogen algunos aspectos de la realidad no sólo literaria, como vemos en "Inmigrante": “En el cadáver / que el mar ha vomitado / sonaba un móvil".

Pilar Fraile y Lorenzo Oliván entregan algunos ejemplos de poesía esencial, en concreto este último, de su libro 
Murcia. Esa lenta gestación provoca, como consecuencia más inmediata, que la calidad y selección de los textos publicados esté fuera de toda sospecha. Sin embargo, no es sólo esto lo que hace excepcional a Hache, sino el hecho de que no se trata de una publicación al uso de las muchas que siguen proliferando hoy en día por el denso panorama de las letras hispánicas, sino que resulta, en su conjunto, una revista mucho más completa $\mathrm{y}$, al mismo tiempo, menos ingenua en sus planteamientos que otras aparentemente análogas. Tanto esa periodicidad anual, como la estupenda encuadernación en rústica, a lo que se añadiría el sumo cuidado de la presentación de los textos, han conseguido que, de alguna manera, se erija en un puesto de indudable singularidad respecto a muchas otras publicaciones que pudieran parecer semejantes, convirtiéndose así en una de las más completas antologías anuales que vienen recogiendo desde hace seis años lo más significativo de la poesía hecha actualmente en nuestro país.

En pleno siglo veintiuno, estando como estamos, desgraciadamente, acos- tumbrados a ver en las revistas líricas una estética sin lugar a dudas trasnochada, Hache sorprende no sólo por su indiscutible atractivo visual (del cual es sobre todo responsable Cristina Morano), sino por aunar al propio concepto más tradicional y común de revista de poesía el espíritu transgresor del fanzine literario. Con ello consiguen una propuesta más que sugerente y de altísima calidad, que ofrece una perfecta e inusual sintonía entre el material poético, la tipografía especial escogida para los textos y las singulares ilustraciones que los acompañan. Consiguen así que, para el lector, estos aspectos concurran en una integración plena como parte indisoluble e indiscutible del mismo proceso poético.

Para conseguir esto en el campo de la ilustración hemos asistido, en los cuatro números anteriores al que aquí comentamos, a la colaboración de autores gráficos como el valenciano Ángel Haro, o artistas del ámbito murciano, aunque con gran proyección internacional, como Antonio Martínez Mengual, Miguel Fructuoso o el fotógrafo José Luis Montero. En el terreno plenamente literario, rivadas del estudio de tal corpus. Sin embargo, Díez Fernández antes de analizar con más detenimiento la discutida formación de su cancionero, su vertiente octosilábica, en la que destacó sobremanera, la importancia de su corpus epistolar y sus textos burlescos y eróticos, donde Mendoza deja muestras de su gran talento, señala la escasa distancia que media entre las composiciones del poeta y la actualidad. Para ello propone como ejemplo las epístolas y la poesía erótica, pues resultan menos estereotipadas que su vertiente petrarquista, y se traducen en "una apuesta por la amplitud, temática y formal, que no está (o no está en el mismo grado) ni en Boscán ni en Garcilaso" (p. xxx).

La recepción de este corpus ha dado lugar a numerosas "reiteraciones y reticencias", título nada gratuito y muy revelador, bajo el que el profesor Díez recoge las valoraciones críticas sugeridas por el mismo. Con estos párrafos, se pretende superar aquellas ideas prefijadas y perpetuadas durante años: su descuido en la construcción de los metros, su contribución al triunfo y consolidación de la nueva poesía, su ansia de re- novación, el silencio al que fueron relegadas sus composiciones "menos serias", la consideración y estima de que gozaron sus redondillas,... También los aciertos y desaciertos de los estudios y ediciones más modernas (Díaz Hidalgo Morel-Fatio, Knapp, González Palencia, Mele, P. Bohigas, Díaz Larios, Gete Carpio,...) son revisados por el profesor Díez.

Como se desprende de lo reseñado en los epígrafes anteriores parece evidente que recrear la trasmisión textual de la obra poética de Diego Hurtado de Mendoza no es tarea exenta de riesgos y escollos. El complejo entramado de ediciones, la ausencia de textos publicados en vida bajo el cuidado del propio poeta, la difusión manuscrita de muchos de sus poemas y las atribuciones múltiples han impedido en buena medida, la delimitación y fijación de su corpus. Pero, sobremanera, han dificultado las tareas de edición, la filiación de los testimonios.. De todas estas cuestiones da cuenta Díez Fernández en la penúltima sección de la introducción "Ariadna sin hilo: una laberíntica transmisión textual". En estas páginas, además, se argumenta y justifi- 
ca la elección del texto base de la edición.

Dadas las paradojas registradas en el autógrafo y las peculiaridades de la editio princeps, el editor se decanta por una tercera vía: el ms. 4256 de la BNE, que, como reza en los "Criterios de edición", último apartado de estudio introductorio, es "la fuente más interesante para construir el texto base, tanto por el número de poemas que copia, como por representar un estadio anterior al de otras fuentes [...], como, finalmente, por ofrecer numerosas lecturas muy superiores a las de la edición príncipe" (p. lxxxix). También se explica en este apartado la división y distribución de los poemas en el volumen. Un primer grupo de textos lo constituyen todos aquellos poemas sobre los que no existe duda alguna de autoría. El segundo, en cambio, recoge los textos atribuidos al poeta. Ambos grupos están editados de manera rigurosa y acompañados de una anotación mínima, pero pertinente. La edición se clausura con un "Apendice" que alberga los preliminares de la edición príncipe, Las coplas de don Diego de Leiva y «No es mía ni mala».

Es evidente, tras lo arriba expuesto, que la obra constituirá, sin duda, un punto de referencia y marcará un antes y un después en la recepción y edición de la vida y obra de don Diego Hurtado de Mendoza, gracias, claro está, al cuidado, rigor y pulcritud del profesor Díez Fernández, pues el volumen no es más que una nueva muestra del buen trabajo al que siempre nos tiene acostumbrados.

HÉCTOR CASTILLA Y CRISTINA MORANO, (EDS.), HACHE 5 (MAYO, 2008), 112 PP.

MARIo PAZ GONZÁLEZ INSTITUTO LOS LLANOS. CAMARZANA DE TERA. ZAMORA

Al comentar una revista de poesía siempre da la impresión de que se está hablando de una empresa quimérica, tal vez, incluso, absurda, banal, ineficaz o transitoria. Por eso, al hablar de Hache («esta locura en negro y plata», en palabras de sus creadores) estamos hablando de un caso que resulta excepcional por muchas razones que aquí se podrían aducir. Una de esas razones sustentadora de esa excepción es la de su carácter anual, pues sólo ha sacado a la luz hasta el momento cinco números (siempre en primavera) desde que comenzó a ser editada en abril de 2004 por el poeta y locutor radiofónico Héctor Castilla y la también poeta Cristina Morano, en colaboración con el Museo de la Ciudad de 
JOSÉ MONTERO ALONSO, ANTOLOGÍA DE POETAS Y PROSISTAS ESPAÑOLES, EDICIÓN FACSÍMIL CON PRÓLOGO DE JOSÉ MONTERO REGUERA Y ALEXIA DOTRAS BRAVO, VIGO: TÓRCULO ARTES GRÁFICAS

2008, 450 PP.

CRISTINA COLLAZO GÓMEZ UNIVERSIDAD COMPLUTENSE DE MADRID

Como si de un juego metaficcional se tratase, aparece la doble condición: un libro que recoge otro libro. Con esta característica, José Montero Reguera y Alexia Dotras Bravo prologan la edición facsímil de la Antología de poetas y prosistas españoles. Ambos escritores (y profesores en la actualidad) ofrecen un reco- rrido por la vida de José Montero Alonso, así como su carrera profesional. Sin embargo, el campo no se limita a meros datos biográficos, sino que se completa con una aproximación a la historia de la literatura infantil y ciertas problemáticas que le atañen, trayendo a colación estudios y estudiosos sobre el tema. Asimis- 
mo, se finaliza con una panorámica del contenido que a continuación se muestra, no antes sin ofrecer dos cartas y dos artículos ilustrativos que los prologuistas citaron con anterioridad.

Con tamaña aseveración: “esta obra obtuvo el Premio Nacional de Literatura correspondiente al año 1928", se inicia la antología y predispone la aparición de aquellos autores y obras más relevantes de las letras españolas (desde el siglo XII hasta principios del siglo $X X)$.

La finalidad de la obra es pedagógica, pues resultó ganadora en un concurso en que se quiso premiar "un libro de lectura para las Escuelas nacionales de niñas y niños". Se pretende ofrecer una breve historia literaria que recoja los paladines de nuestra literatura siendo esta tarea harto dificultosa. No obstante, la presentación de los autores elegidos, así como la selección de fragmentos y poemas, revisten una estructura didáctica.

Se inicia la antología siguiendo una periodización tradicional por épocas y movimientos: parte de la poesía heroicopopular medieval, así como prosistas y realiza una amplia selección de las Coplas y Romances de Jorge Manrique, se sirve, a continuación, de Garcilaso para una renovación poética y del culteranismo iniciado por Góngora. La poesía ascética y mística viene de la mano de Fray Luis de León, Santa Teresa de Jesús y San Juan de la Cruz.

Da cuenta de los tesoros con que los grandes del Siglo de Oro nos deleitaron (Cervantes, al que dedica un amplio apartado, Quevedo, Calderón, Rojas Zorrilla..., pero también autores que recupera como Agustín de Moreto, para el género dramático o Vélez de Guevara con la visón caleidoscópica de su "diablo cojuelo", para el picaresco), de las luces de la Ilustración (Moratín o la fábulas de Samaniego e Iriarte), de la luz renovada del Romanticismo (como transición hace hincapié en Alberto Lista y Nicasio Gallego, así como Tamayo y Baus para el género dramático, autores quizás menos tratados, a diferencia de Larra, El Duque de Rivas, Bécquer o Rosalía).

Menciona también escritores de menor renombre (Bretón de los Herreros y Ventura de la Vega) paralelos a estos, pero que "no se incorporan en su labor al nuevo movimiento..." y pertenecen, sin embargo, al naturalismo. En este último grupo incluye a Valera, Pereda, Emilia Pardo Bazán y Galdós.

Antes de dar paso a la tan controvertida generación del 98 (Ganivet, Salvador Rueda), reserva numerosas páginas donde recoge el positivismo y materialismo representado por Maragall.

La presentación de cada autor reviste aspectos diferentes, resaltando unos $\mathrm{u}$ otros según su criterio, he aquí su importante labor crítica (no se debe obviar las dotes periodísticas de José Montero Alonso). La extensión de cada apartado puede verse dilatada por la inclusión de notas anecdóticas significativas (por ejemplo, la misteriosa mujer que inspiró los poemas de Bécquer, así como la que inspiró a Espronceda) e incluye también pequeños detalles que atañen a la personalidad de los autores ("Agustín de Moreto...es hábil, sutil, risueño..."). Su capacidad crítica aludida en líneas anteriores se ve asimismo reflejada en las continuas relaciones y comparaciones que José Montero Alonso realiza. De esta manera, aplica su visión relacionante a la poesía (“...Garcilaso es suave y amoroso en sus versos... Fernando de Herrera, por el contrario...vigoroso, arrebatado y marcial..."), prosa (hablando del género picaresco cultivado por Vicente Espinel: “...lejos de...la reflexión que hay en el Guzmán de Alfarache de Mateo Alemán...") y teatro (“...el teatro de Lope es de pasión, el de Calderón es de pensamiento...").

Otro elemento que se muestra clarificador y de gran utilidad pedagógica es el empleo de una síntesis de lo expuesto, fijando así conocimientos en un esfuerzo por recordarlo o acudir a dichas páginas.

La obra, por tanto, pone de manifiesto una selección de autores con sus aportaciones más destacadas, y constituyó un hito pionero en la historia de la literatura destinada a la infancia en España. 
fica. Nada hay más personal que un epistolario, cuando menos en lo que atañe a las contingencias de lo cotidiano y a las relaciones sociales, familiares o culturales. En su famosa novela Huida sin fin, Roth crea un protagonista, llamado Franz Tunda, con quien coincide, por desgracia, en los aspectos más luctuosos. Nos referimos a que la vida del escritor, fue también una «huida sin fin», desde su nacimiento en Brody, sus estudios de germanística en Viena, su paso por la Primera Guerra Mundial, la prisión en Rusia, sus viajes por Francia y Alemania, etc., hasta su muerte exiliada y prematura en París.

Las Cartas son un reflejo directo nunca completo - de esa odisea y, especialmente, de su exilio. Pero también lo son sus cuentos, relatos y novelas. Las Cartas forman, de hecho, parte de una supraunidad, la obra literaria de Joseph Roth. Al leer las cartas, se descubre multitud de referencias a la génesis de sus obras y se advierte la unidad profunda de la escritura del autor austriaco. He ahí el valor literario y filológico de estas Cartas. Es mucho más que un mero epistolario anecdótico, que, en el caso de
Roth, ya sería muy interesante y revelador. En realidad son una radiografía espiritual del verdadero Roth. Por último, no podemos pasar por alto al destinatario por excelencia de las epístolas de Roth. El grueso de las Cartas van dirigidas a Stefan Zweig, ejemplo emblemático, como el propio Roth, de la persecución ultranacionalista del Tercer Reich El terror fundado a la represión de Hitler es compartido. Ambos tuvieron que exiliarse y ambos murieron prematuramente lejos de su patria. Además, ambos compartían con el filólogo Víctor Klemperer una pasión - frente a los bárbaros del «infame alemán regañón», Roth dixit-, la del amor a la lengua alemana.

Quizá una de las estampas más emotiva - a la vez que literaria - sea la del autor de El busto del emperador y La Cripta de los Capuchinos haciendo guardia en la mismísima Cripta vienesa donde todos los miembros de la monarquía austriaca reposan, augurando quizá un futuro muy distinto: «[...] cuando murió el emperador Francisco José, yo era un "revolucionario", pero lloré. Me enrolé voluntario por un año en un re- 
gimiento vienés, una "tropa de élite"

que hacía guardia de honor ante la crip- ta de los capuchinos, y lloré de veras.

Una época quedó enterrada.» (p. 76)
MARAVAll, J. A., La cultura del Barroco. Análisis de una estructura histórica, Barcelona, Ariel, 1983 
Si se repite la misma obra o artículo y varía la página, se citará siempre del siguiente modo: J. A. Maravall, op. cit., p. 326; o vid. J. A. Maravall, op. cit., p. 328.

Si se repite de forma inmediata la misma obra y página, se pondrá: Ibidem; si cambia la página: Ibidem, p. 345 .

\section{EPÍGRAFES}

- Los epígrafes siempre irán numerados (nunca números romanos) en negrita y al inicio del párrafo. Si incluyen título deberán mantener el siguiente orden:

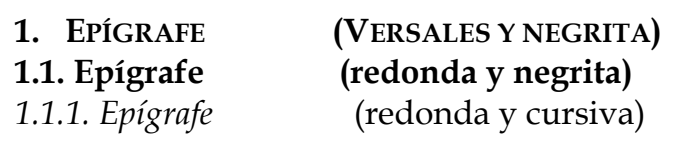

\section{BIBLIOGRAFÍA}

- Si el autor quiere añadir al final del trabajo una Bibliografía, la titulará (en letra versalita y centrada). Las entradas bibliográficas, que deberán llevar una sangría francesa de $1^{\prime} 5 \mathrm{cms}$., se harán de la siguiente forma:

a) Artículo en revistas: APELLIDOS, Nombre, «Título del artículo», Nombre de la Revista, Número o Volumen (año), páginas:

LARA, J., «Vicente Espinel, un poeta entre dos siglos. Romancero, música y lírica cantada desde un ramillete de nuevos textos», Canente. Revista Literaria, 2 (2001), pp. 83-166.

b) Artículo en obra colectiva: ApELLIDOS, Nombre, «Título del artículo», en Nombre Apellidos (Editor o Compilador), Título de la obra, Ciudad, Editorial, año, páginas:

García Montero, L., «Luis Cernuda y Andalucía», en J. Matas et alii (eds.), Nostalgia de una patria imposible. Estudios sobre la obra de Luis Cernuda, Madrid, Akal Universitaria, 2005, pp. 47-61.

c) Libro: ApelLidos, Nombre, Título del libro, Ciudad, Editorial, año:

\section{Resúmenes}

TíTULO: «Las cartas de un gentilhombre de placer: Gonzalo de Liaño, “Trompeta en esta corte"»

AuTOR: Nieves Baranda

RESUMEN

Gonzalo de Liaño (†1588) fue enano y bufón de Felipe II, pero sus habilidades eran mucho más amplias, ya que fue agente del rey. Durante los últimos años de su vida, a partir de 1579 al menos, viajó entre España e Italia. Su principal tarea era atender al traslado de objetos artísticos y valiosos entre las cortes. Conocemos sus viajes a través de las cartas que escribió a los Grandes Duques de Toscana, Francsco I y Bianca Capello. Sus cartas, una muestra excepcional del estilo jocoso, muestran que no fue un agente corriente, sino muy astuto, empleando el humor y el ingenio para acceder a los poderosos y conseguir sus fines. A fin de mostrar estas habilidades bufonescas, se editan algunas de sus cartas a la Gran Duquesa conservadas en el Archivio di Stato de Florencia.

PALABRAS CLAVE: Cartas. Relaciones España-Italia. Literatura bufonesca. Felipe II. Florencia

\section{Abstract}

Gonzalo de Liaño (d. 1588) was a dwarf and jester of the Spanish king Felipe II but is abilities were much broader as he was also an agent of the king. During the last years of his life, since 1579, he travelled between Spain and Italy. His main duty was to take care of artistic and valuable objects travelling from one court to the other. We know about his extensive travelling through the letters he wrote to the Grand Dukes of Tuscany, Francesco I and Bianca Capello. His letters, an unique evidence of the facetious style, reveal he was not a common agent but a very clever one who used humour, jokes and wit as a means of making his way to the members of the ruling class and getting his ends. 
As a way to show his facetious abilities some of his letters to the Grand Duchess of Toscana from the Archivio di Stato di Firenze are edited.

KEY WORDS: Letters. Relationships Spain and Italy. Fool Literature. Philip 2nd. Florence.

TíTULO: «Historia sagrada y loa sacramental en Calderón»

AUTOR: Vanessa Fortuño Gómez

RESUMEN

Antes de comenzar el estudio de la historia sagrada en las loas sacramentales calderonianas, se comprueba la existencia del tiempo tanto en el plano historial como en el alegórico. Con respecto ya al uso de la historia sagrada, se observa que ésta aparece generalmente mencionada a causa de la brevedad propia del subgénero dramático. Tanto las contadas excepciones en que esta materia aparece dramatizada como casi todas las citas bíblicas cumplen en el plano historial una función argumentativa, argumental, en algún caso alegórica y, para el espectador implícito de la fiesta, catequística; aunque unas pocas de esas referencias tienen una intención comparativa y no catequística. Mientras que en el plano alegórico, la historia sagrada está más cerca de la tradición de la Iglesia que del texto bíblico y su función resulta ser a un tiempo alegórica y catequística.

PALABRAS CLAVE: Calderón, teatro, loa sacramental, Historia Sagrada, alegoría.

Abstract

Before beginning the study of Sacred History in Calderón's sacramental 'loas', we verify the existence of time in these works. In general, due to the brevity of the genre, Sacred History is only mentioned. On the few occasions when this material appears in dramatized form in the 'loas', it performs the same functions as the biblical quotations: argumentation, argument, allegory, doctrine for the implicit spectator and, occasionally, comparison. As regards the allegorical side, Sacred History approaches the tradition of Catholic Church and rather forgets the biblical text; the function is allegorical and doctrinal.

KEY WORDS: Calderón, theater, sacramental loa, Sacred History, allegory.
- La supresión de texto dentro de una cita se indicará con tres puntos suspensivos entre corchetes: [...].

- Para las citas en el cuerpo del texto se utilizarán siempre las comillas latinas españolas «»; si dentro de esa cita hubiera que incluir otra, se haría con las comillas inglesas “"”.

- El número de la llamada de la cita o nota irá volado o en superíndice, sin paréntesis, y se colocará después del signo de puntuación.

\section{NOTAS A PIE DE PÁGINA}

- En las notas a pie de página, las citas bibliográficas deben hacerse de la siguiente manera:

a) Artículo en revistas: Nombre Apellidos, «Título del artículo», Nombre de la Revista, Número o Volumen (año), páginas:

J. Lara, «Vicente Espinel, un poeta entre dos siglos. Romancero, música y lírica cantada desde un ramillete de nuevos textos», Canente. Revista Literaria, 2 (2001), pp. 83-166.

b) Artículo en obras colectivas: Nombre Apellidos, «Título del artículo», Nombre Apellidos (Editores o Compiladores), Título de la obra, Ciudad Editorial, año, páginas:

L. García Montero, «Luis Cernuda y Andalucía», en J. Matas et alii (eds.), Nostalgia de una patria imposible. Estudios sobre la obra de Luis Cernuda Madrid, Akal Universitaria, 2005, pp. 47-61.

c) Libro: Nombre Apellidos, Título del libro, Ciudad, Editorial, año, páginas del libro:

I. A. Maravall, La cultura del Barroco. Análisis de una estructura histórica Barcelona, Ariel, 19833, pp. 226-267. 


\section{FUENTE}

- Fuente: 12 Book Antiqua para el texto y 10 para citas textuales y notas a pie de página.

\section{TÍTULO}

- El título del trabajo irá en mayúscula, en negrita, centrado y encabezando el trabajo.

- El nombre del autor del mismo ha de ponerse siempre, tras un interlineado en blanco, debajo del título, centrado y en letra versalita.

- Debajo del nombre del autor, en la línea siguiente, también centrado, y justo debajo de él, se pondrá en letra redonda la Universidad - u otro centro de trabajo - a que pertenece el autor.

- Las reseñas llevarán como encabezado la referencia completa del libro comentado, con el siguiente orden: Nombre Apellidos, Título, Nombre del editor, traductor o compilador, Ciudad, Editorial, año, número de páginas. El nombre del autor (o autores) de la reseña aparecerá bajo el título, alineado al margen derecho. Las reseñas no llevarán notas al pie de página, ni bibliografía al final

\section{Citas}

- Las citas textuales, que tengan una extensión de más de tres líneas, deben llevar un sangrado en el margen izquierdo de $2 \mathrm{cms}$., y el margen derecho debe ir justificado igual que el resto del trabajo; deben tener un interlineado en blanco antes y después de la cita, que no debe ir entre comillas:

Aceptar que el Jardín de flores curiosas es quizá una de las fuentes del Persiles y sumar a esta hipótesis el poco positivo juicio que tradicionalmente ha merecido la última novela de Cervantes es posible que haya repercutido, con justicia o sin ella, sobre la valoración de un autor, Antonio de Torquemada, que previamente había gozado de la sorna cervantina.
Tí́tulo: «Documentos sobre Jerónimo de Cáncer y Velasco (parte II)» AUtOR: Alejandro Rubio San Román y Elena Martínez Carro

RESUMEN

La figura de Jerónimo de Cáncer ha sido estudiada, en estas últimas décadas, desde distintas perspectivas. Sin embargo los datos biográficos conocidos siguen siendo muy escasos. El presente artículo pretende aportar algunos documentos inéditos sobre la vida del dramaturgo áureo, con el fin de abrir el camino a una biografía más completa y real.

PALABRAS ClAVE: Teatro, Jerónimo de Cáncer, documentos.

\section{Abstract}

Jeronimo de Cancer's figure has been studied during these latest decades from different views, however his known biographical details are still very limited. This article tries to suply some unpublished documents about the golden dramatist's life, with the aim of opening the way to a more complete and real biography.

KEY WORDS: Theatre, Jerónimo de Cáncer, documents.

Título: «Europa vista desde Ámsterdam: Laus urbium en la obra poética de Miguel (Daniel Leví) de Barrios»

AUTOR: Inmaculada García Gavilán

RESUMEN

El presente estudio explora la varia fortuna que ha venido experimentando el subgénero de la laus urbium, sin duda uno de los más dúctiles y atractivos de la literatura encomiástica, desde su formación en época helenística hasta finales del siglo XVII. Se examina en estas páginas una ejemplar muestra de esta dilatada pervivencia: los elogios incluidos por el poeta y dramaturgo sefardí Miguel (Daniel Leví) de Barrios (1635-1701) en uno de sus poemarios más logrados, Coro de las Musas (1672), y que dedica, desde su particular exilio flamenco, a diversas capitales europeas.

PALAbras Clave: Literatura encomiástica, Laus urbium, Daniel Leví de Barrios, Coro de las Musas, Europa. 


\section{AbStRact}

The present document studies the varied fate experienced by the laus urbium which, since its birth in the Hellenistic era to the end of $17^{\text {th }}$ century, undoubtedly is one of the most flexible and attractive sub-genre of the laudatory literature. One exemplary specimen of this extensive survival is studied in these pages: the eulogies included by the Sephardic poet and dramatist Miguel (Daniel Levi) de Barrios (1635-1701) in one of his best anthology of poems, Coro de las Musas (1672), which he dedicates, from his Flemish exile, to various European capitals.

KEY WORDS: Laudatory Literature, Laus urbium, Daniel Leví de Barrios, Coro de las Musas, Europe.

Tí́tulo: «Narrar el problema obrero: permanencias y rupturas en tres crónicas martianas»

AUTOR: Luciana Andrea Mellado

\section{RESUMEN}

Este artículo examina tres crónicas de Martí que desarrollan narrativamente el mismo tema: el problema obrero producido en los Estados Unidos en 1886. El objetivo es analizar las continuidades y rupturas discursivas más importantes que entre ellas existen en la representación del conflicto y sus actores sociales.

PALABRAS CLAVE: Martí, crónicas, Escenas norteamericanas, periodismo, modernismo.

\section{Abstract}

This article examines Martís sthree chronic that narratively developed the same theme: the worker problem produced in the United States in 1886. The objective is to analyze the most important discursive continuities and ruptures in the representation of this conflict and their social actors.

KEY WORDS: Martí, chronics, North American Scenes, journalism, modernism.

\section{NORMAS DE EDICIÓN LECTURA Y SIGNO}

Los trabajos se dirigirán a la dirección de la revista: Juan Matas Caballero /José María Balcells Doménech. Universidad de León. Facultad de Filosofía y Letras. Dpto. Filología Hispánica. Campus de Vegazana. León. 24071. Correo electrónico: ulelys@unileon.es

Los originales se enviarán impresos en papel (por duplicado) y en soporte informático. También podrán enviarse por correo electrónico.

Los libros, revistas, actas, etc., para reseñar se enviarán también a la dirección de la revista. De todos ellos se dejará constancia en la sección de libros recibidos. No se devolverán las publicaciones recibidas.

La aceptación de los trabajos será sometida a la valoración favorable de evaluadores externos.

La extensión máxima recomendable de los trabajos será de 30 páginas para los ARTículos, 15 para las NOTAS y 6 para las ReSEÑAs, aunque podrán publicarse trabajos de mayor extensión cuando su interés lo aconseje.

Los artículos y notas irán precedidos de un resumen (RESUMEN) de su contenido en español e inglés (ABSTRACT) de una extensión máxima de 10 líneas cada uno y de cinco palabras clave en español (PALABRAS CLAVE) e inglés (KEY WORDS) que condensen el contenido de los trabajos.

Los trabajos deberán ajustarse a las siguientes normas de estilo:

\section{INTERLINEADO}

- Interlineado: 1,5 para el texto y sencillo para citas textuales y notas a pie de página. 
Título: «Los “Bocetos” de Remedios Varo»

Autor: Edith Mendoza Bolio

\section{RESUMEN}

El universo de Remedios Varo está contenido principalmente en su producción pictórica. Sin embargo adentrarse en la obra escrita de esta artista española, exiliada en México, amplía la comprensión de su imaginario. Entre el acervo escrito de Varo se encuentran relatos oníricos, narraciones, cartas y una obra de teatro escrita en colaboración con Leonora Carrington. Adicionalmente, el estudio y la edición de sus escritos han permitido desarrollar la noción de «constructo creativo» que alude a la silenciosa complementariedad entre los diversos lenguajes utilizados y la forma en que potencian su sentido.

PALABRAS ClaVE: Remedios Varo, constructo creativo, relatos oníricos, exilio, manuscritos.

\section{Abstract}

Te universe of Remedios Varo is most evident in her pictorial production, however venturing into the written texts of this Spanish artist, exiled in Mexico, allowed for a more clear understanding of her imagination. Among the Varo's collection of texts are dreamlike narratives, stories, letters, and a play written in collaboration with Leonora Carrington. Furthermore, the study and publication of her writings have contributed to develop of the concept of "creative construct" which refers to the silent complementarity between the various artistic languages used and the way in which they enhance meaning of her works.

KEY WORDS: Remedios Varo, creative construct, oneiric stories, exile, manuscripts

Título: «Notas a un texto inédito de Max Aub: su comentario a Hombre y Dios de Dámaso Alonso (1955)»

Autor: Pablo Carriedo Castro

RESUMEN

En los alrededores de 1955, Max Aub inicia, desde su exilio en México, una serie de contactos epistolares con el mundo intelectual del interior del país. Son éstos apenas una frágil restauración de sus relaciones tras la catástrofe de la Guerra Civil española. Sin embargo, constituyen también el único 
testimonio escrito que nos ha llegado hasta hoy acerca de cómo el escritor valenciano intentó superar el aislamiento y la incomunicación y, así, poder seguir y comprender los nuevos caminos de la cultura española bajo la dictadura franquista. El inédito que aquí se presenta ilustra, desde el ámbito más privado y personal, el modo en que Max Aub desarrolló ese trabajo, en concreto, sobre un comentario a un libro de su amigo Dámaso Alonso.

PALABRAS ClAVE: Poesía, amistad, política, Guerra Civil española, exilio

\section{ABSTRACT}

From his exile in Mexico, approximately in 1955, Max Aub began to do some contacts with intellectuals who remained in the country after the Spanish Civil War. They were a very fragile restoration. Anyhow, they are also the only one written testimony that we keep now days on how the writer tried to overcome the isolation and to know and understand the new ways of the Spanish culture during the Franco's dictatorship. The unpublished text presented here shows, from the most private and personal radium, how Max Aub developed that work, commenting concretely a book of his friend Dámaso Alonso.

KEY WORDS: Poetry, friendship, politics, Spanish Civil War, exile

TítUlo: «Un poeta y dos revistas: José María Fernández Nieto en Nubis y Rocamador» AUTOR: Mario Paz González

RESUMEN

La presencia de las revistas poéticas en la posguerra española es indudable, pues no sólo sirvieron para dar voz al exilio (exterior e interior), sino también para reconstruir el pensamiento intelectual del país. En la ciudad de Palencia el nacimiento de dos de estas revistas, Nubis y Rocamador, estará vinculado a la figura del poeta José María Fernández Nieto. La primera surgirá como un producto heterogéneo y excesivamente ambicioso. La segunda, exclusivamente poética y alejada de toda tendenciosidad, será creada por Fernández Nieto y Marcelino García Velasco. En ella, a través de sus sucesivos editoriales, se irá gestando toda una personalidad propia sustentada en diversos aspectos: 1) función estética; 2) subjetividad y misterio; 3) preocupación trascendente; d) actitud política; y e) importancia de la temática amorosa.

PALAbRas ClavE: Poesía Posguerra, Revistas Poéticas, Palencia, Fernández Nieto, Rocamador.

\section{REVISTAS DE INTERCAMBIO}

\section{Analecta Malacitana \\ Universidad de Málaga \\ Málaga}

España

Anales de Literatura Española Contemporánea

Society of Spanish and Spanish-

American Studies

Boulder (Colorado)

USA

\section{Cuadernos del CEMYR}

Universidad de la Laguna

La Laguna (Tenerife) España

Filología

Universidad de Buenos Aires

Buenos Aires

Argentina

\section{Letras Peninsulares}

Deparment of Spanish

Davidson College

Davidson (NC)

Monteagudo

Universidad de Murcia

Murcia

España

Revista de Filología

Universidad de la Laguna

La Laguna (Tenerife) España

\section{Anales de Literatura}

Universidad de Alicante

Alicante

\section{Castilla}

Universidad de Valladolid

Valladolid

\section{España Contemporánea}

Department of Spanish and

Portuguese

Columbus (Ohio)

Letras de Deusto

Universidad de Deusto

Bilbao

España

El maquinista de la Generación Centro Cultural de la Generación del 27

Málaga

España

Quaderni Iberoamericani

Asociazione Studi Iberici

Turín

Salina

Universitat Rovira y Virgili

Tarragona 


\section{AbStract}

Study of Manuel Ballesteros's last collections of poems. Founder, together with other writers, in the 70s, of the group and literary magazine Yeldo and the prizes of poetry «Diario de León», his poetry is characterized by an existential and symbolic-transcendent view of the reality

There are analyzed his last three titles, three books - three topics - in which the exterior and the interior components are confused. In Los primeros avisos (2002) they are the trip in its be doing and the life in its be happening: Recuerda a un bosque (2001) the elements are the forest and the garden, the nature and the culture -the cultivation itself-; In Las casa abandonadas (2003) they are the desert mansions and empty bodies - death -. In these poemarios there is a permanent effort to polish his style and to simplify forms.

KEY WORDS: Manuel Ballesteros, contemporary poetry, Los primeros avisos, Recuerda a un bosque, Las casas abandonadas.

\section{AbSTRACT}

No doubt there is an important presence of the poetical magazines in the Spanish post war period, since they served, not only to give voice to the exile (outer and inner), but also to reconstruct the intellectual thought of the country. In the city of Palencia the birth of two of these magazines, Nubis and Rocamador, was linked to the figure of the poet Jose Maria Fernández Nieto. The first one was arosen as an heterogeneous and excessively ambitious product. The second one, exclusively poetical and out of any political tendency, was created by Fernández Nieto and Marcelino García Velasco. Throw its successive editorials there grew a specify personality based on several aspects: 1) aesthetic function; 2) subjectivity and mystery; 3) transcendent worry; d) political attitude; and e) the importance of the loving subject matter.

KEY WORDS: Poetry Postwar period, Poetical Magazines, Palencia, Fernández Nieto, Rocamador.

TítUlo: « Los últimos días de Thomas de Quincey de Rafael Ballesteros» AUTOR: Francisco Morales Lomas

\section{Resumen}

La controvertida figura del escritor inglés Thomas de Quincey es abordada de un modo personal y sugestivo por el poeta, narrador y crítico, Rafael Ballesteros, quien ha conseguido una visión plural y amplia de un escritor cuya vida es en sí misma una novela. Construcción narrativa sentimental, racional y precisa.

PALABRAS CLAVE: Quincey, vida, narrativa, sentimientos.

\section{AbStRaCt}

The controversial figure of the writer Englishman (English) Thomas de Quincey is approached in a personal and suggestive way by the poet, narrator and critic, Rafael Ballesteros, who has obtained a plural and wide vision of a writer whose life is in yes the same novel. Narrative sentimental, rational and precise construction.

KEY WORDS: Quincey, life, narrative, feelings. 
Título: ""Roma" y "Oda a Bizancio". Humanismo culturalista en Juegos del Mediterráneo de Carlos de la Rica»

AUTOR: Juan Carlos Merchán Ruiz.

\section{RESUMEN}

Este artículo se centra en el estudio comparativo de dos poemas de Carlos de la Rica, incluidos en su poemario póstumo Juegos del Mediterráneo (2001). En la poesía española de finales del siglo XX se da una impronta culturalista que encabezaron poetas como Luis Antonio de Villena, Pedro Gimferrer o José María Álvarez. Si se contrastan ciertas técnicas, como el mayor o menor distanciamiento del yo-poemático, o determinados motivos, como el imaginario cultural mediterráneo, se puede llegar a aquilatar el tipo de culturalismo de la poesía de Carlos de la Rica.

PAlabras ClavE: Carlos De la Rica, Juegos del Mediterráneo, culturalismo, José María Álvarez, Luis Antonio de Villena.

\section{ABSTRact}

This article pays attention to the comparative study of two poems, written by Carlos de la Rica, both included in his posthumous book, entitled Juegos del Mediterráneo (2001). In the spanish poetry from the final of the 20th century, it came a strong innovating tendency, Culturalism. This tendency was leaded for poets like Luis Antonio de Villena, Pedro Gimferrer or José María Álvarez. But the culturalism in the poetry of Carlos de la Rica is different from that mentioned tendency, specially because of the ego-poetical's treatment, althoug there is coincidence in the Mediterranean cultural imagery.

KEY WORDS: Carlos de la Rica, Juegos del Mediterráneo, Culturalism, José María Álvarez, Luis Antonio de Villena.

Título: «La poética de Antonio Gamoneda: el referente esotérico»

AUTOR: Jorge Machín Lucas.

RESUMEN

El presente artículo versa sobre la obra poética de Antonio Gamoneda, una mística sin trascendencia. Se examina su deseo ontológico de evasión de la realidad hacia un pasado ideal a causa de la angustia de la muerte. Es un intento de redención en el origen del yo poético y de la humanidad. Para ello, se analizarán su concepción inmanente de un "dios" individual en minúscula, de la historia del tiempo, del espacio y del sonido, en búsqueda de una palabra esencial que revele un nuevo origen en el seno materno. Este es el "locus originario" desde el que intentar, baldíamente, reiniciar una historia de perfección humana.

PALABRAS ClAVE: Gamoneda, poesía, mística, premio Cervantes.

\section{ABSTRACT}

This paper deals with the poetic works of Antonio Gamoneda, a mysticism without transcendence. It examines his ontological fondness for an evasion from reality towards an ideal pas because of his anguish over death. It is an attempt of redemption in the origin of the poetic self and of mankind. In order to do so, I will analyze his immanent idea of an individual "god" in lower case, as well as history, time, space, and sound, in search of an essential word that discloses the new origin in the mother's womb. This is the original place from where he tries to restart in vain a history of human perfection.

KEY WORDS: Gamoneda, Poetry, Mysticism, Cervantes Award

TíTulo: « La poesía de Manuel Ballesteros »

AUTOR: Fidel Sebastián Mediavilla.

RESUMEN

Estudio de los últimos poemarios de Manuel Ballesteros (León, 1954). Fundador, junto con otros escritores, en los años 70, del grupo y revista Yeldo y los premios de poesía «Diario de León», su poesía se caracteriza por una mirada existencial y simbólico-trascendente de la realidad.

Se analizan sus tres últimos títulos, tres libros - tres temas - en que se confunden los plano exterior e interior: en Los primeros avisos (2002), es el viaje y la vida en su hacerse -el camino de la vida-; en Recuerda a un bosque (2001), el bosque y el jardín, la naturaleza y la cultura -el cultivo de sí-; en Las casas abandonadas (2003), mansiones desiertas y cuerpos vacíos - la muerte-. Un permanente esfuerzo de depuración de estilo, de simplificación de formas.

PALABRAS CLAVE: Manuel Ballesteros, poesía contemporánea, Los primeros avisos, Recuerda a un bosque, Las casas abandonadas.

LECTURA Y SIGNO, 4 (2009), pp. 375-38 